

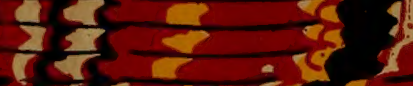

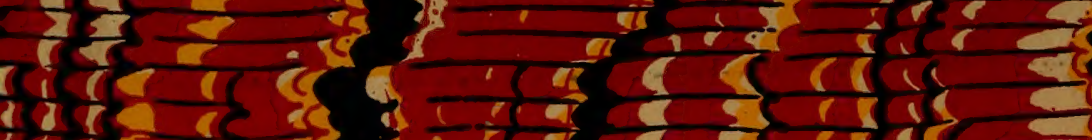

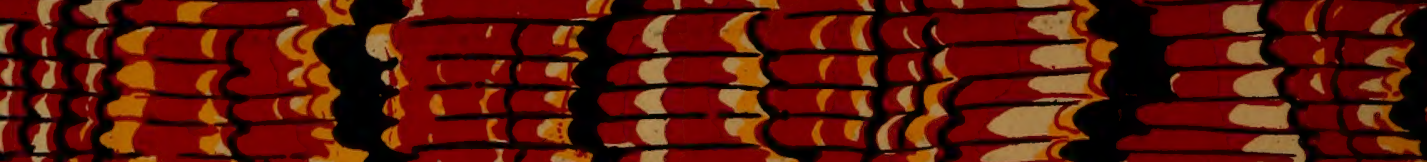

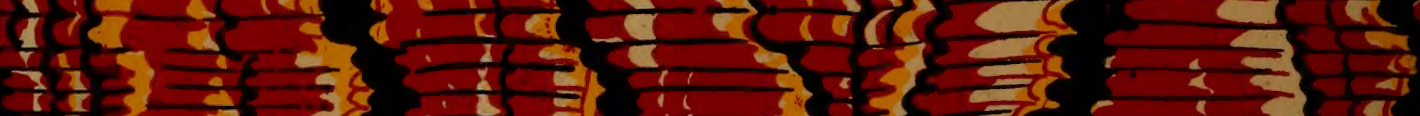

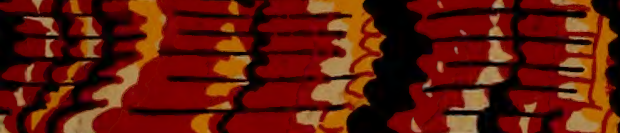
तो के का itris

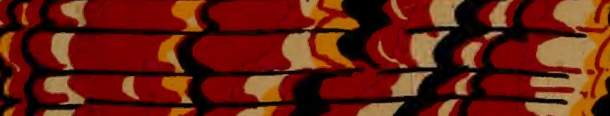

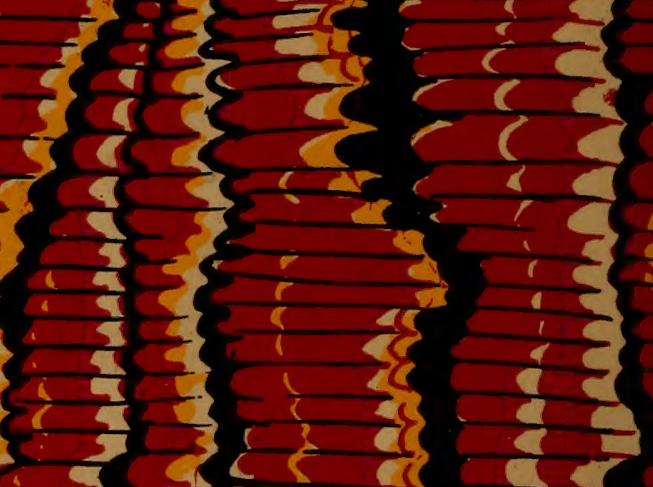

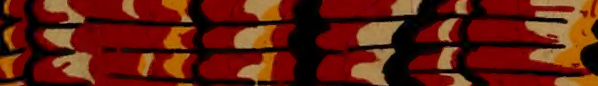
हो सो से है है

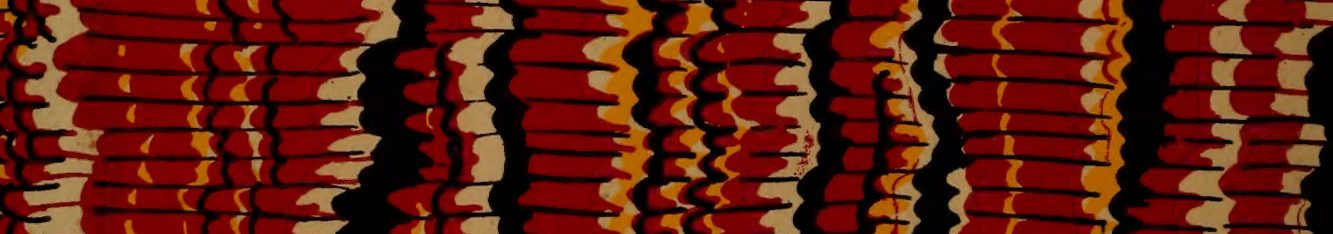
=i

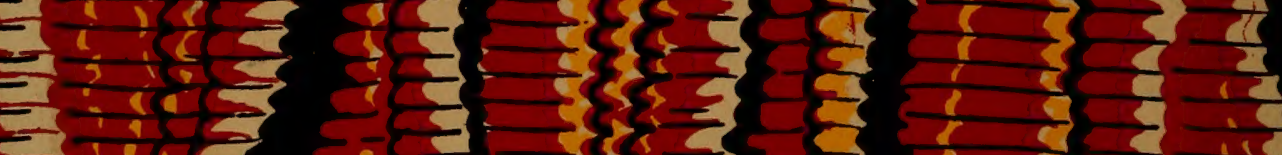

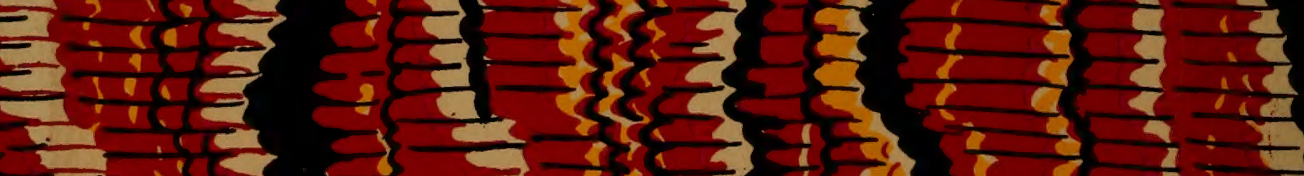

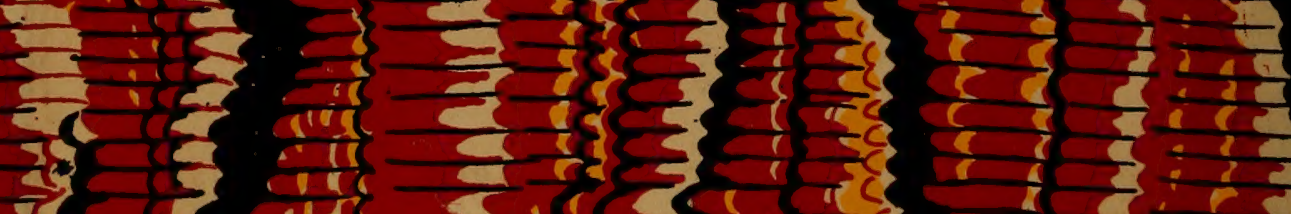

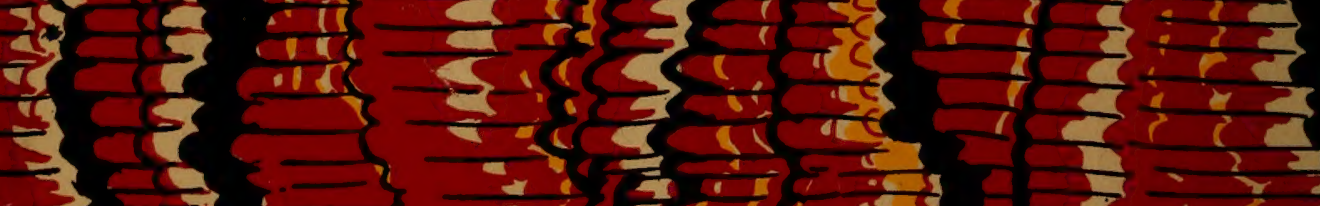
$\frac{1}{2}$

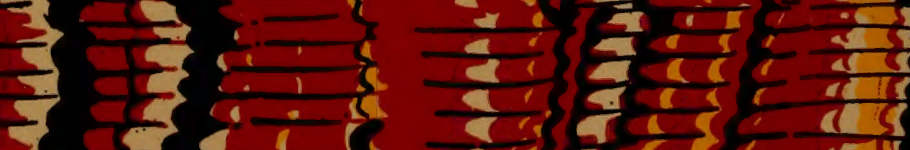

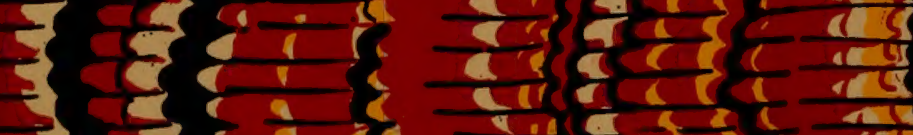

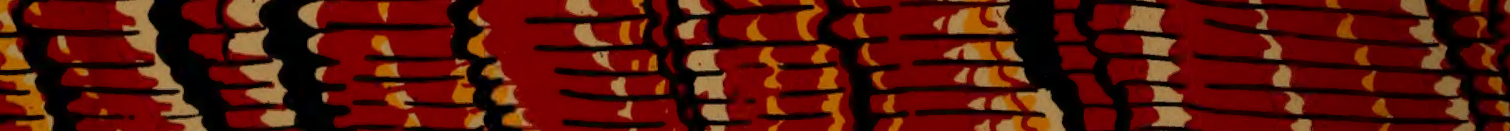
3 -

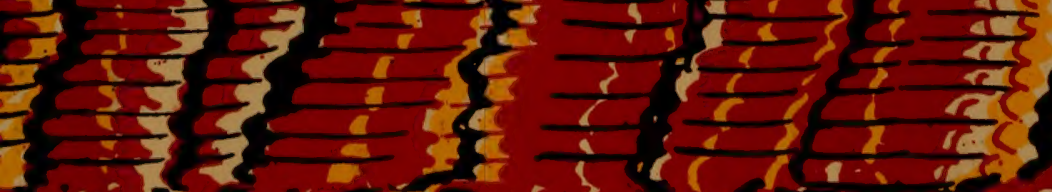

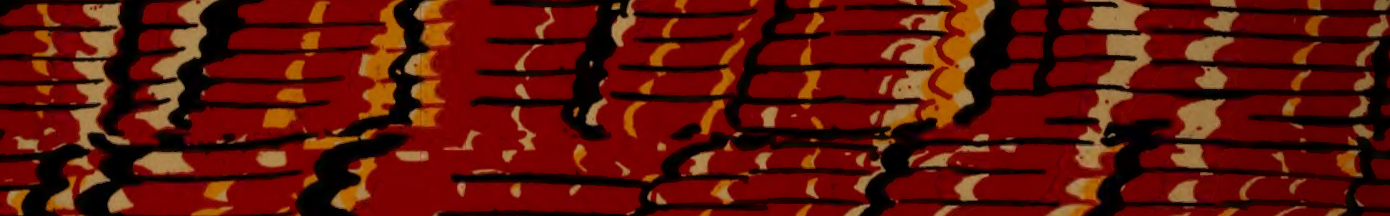
$7{ }^{2}$
5

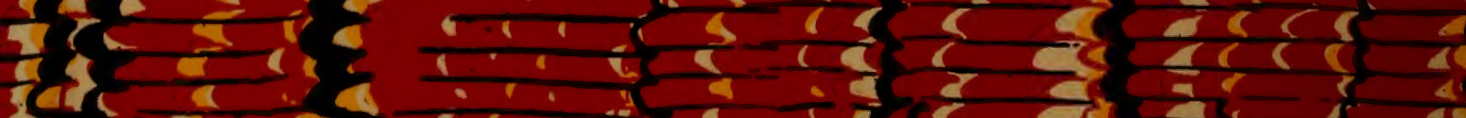

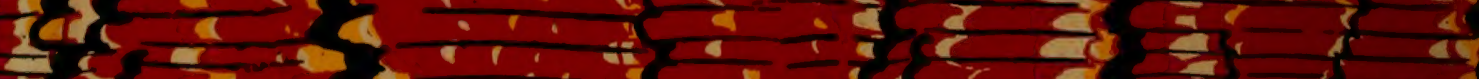

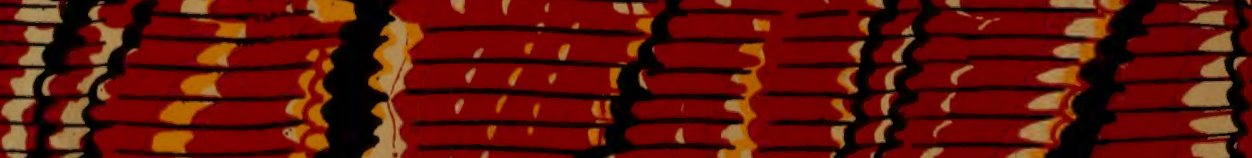
सैदे है के

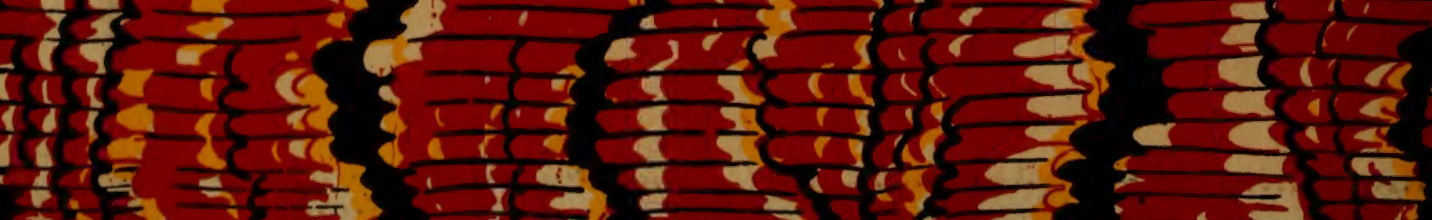

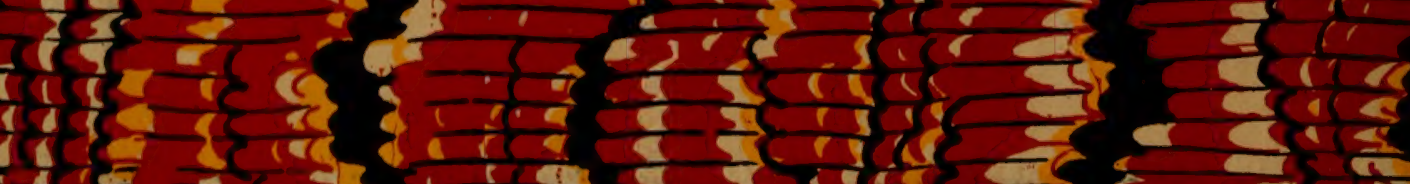




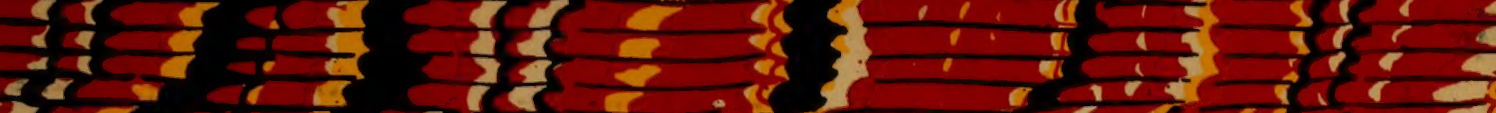

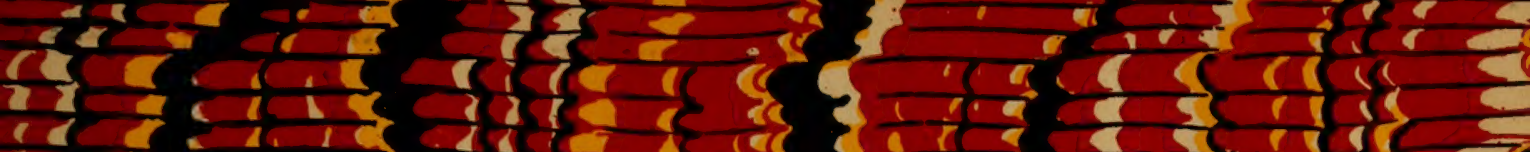

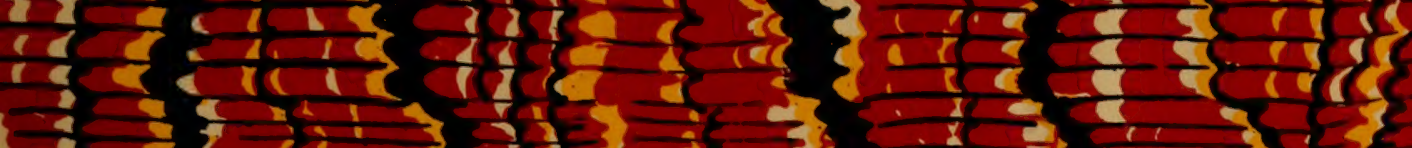

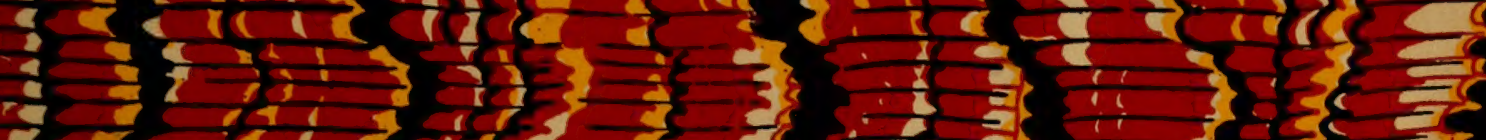

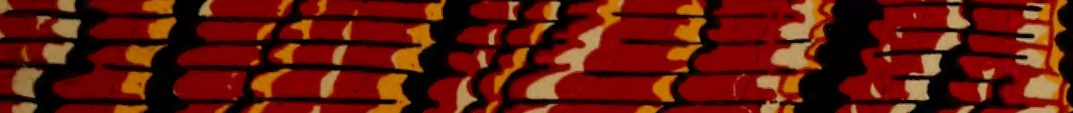

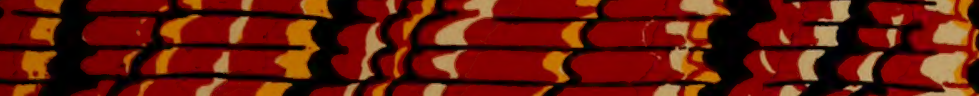

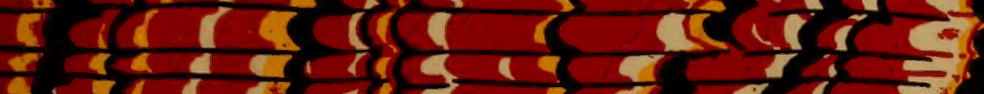

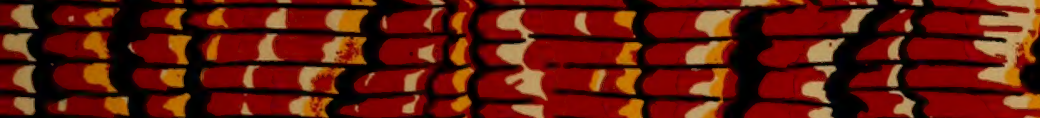

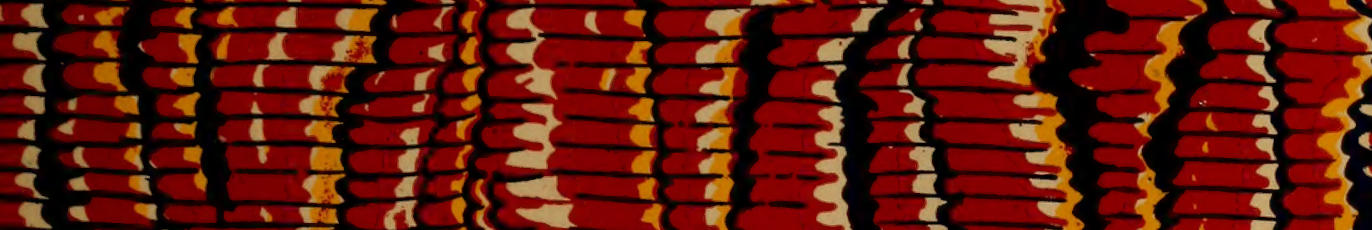

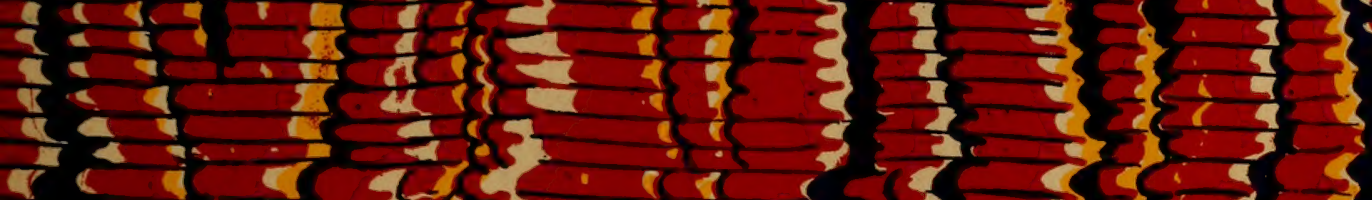

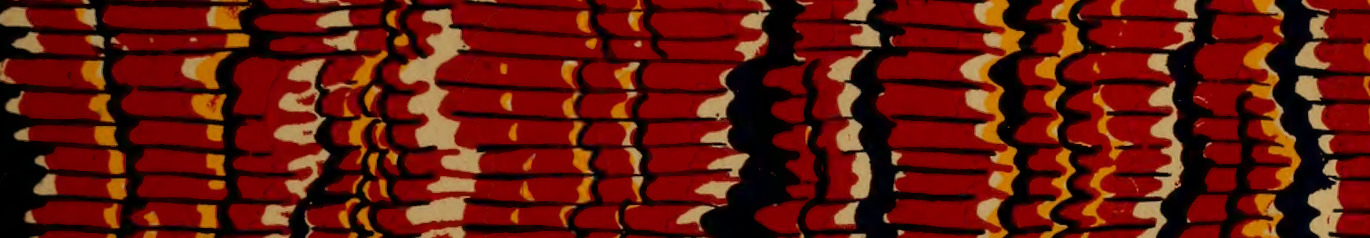

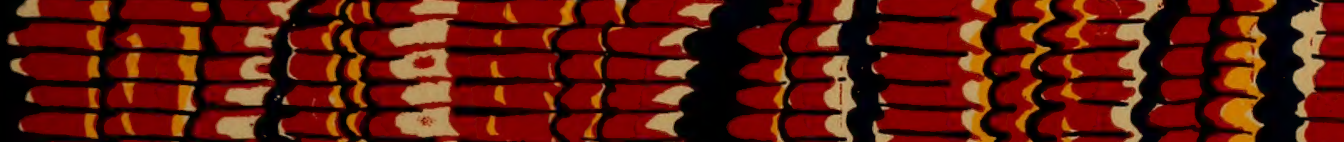

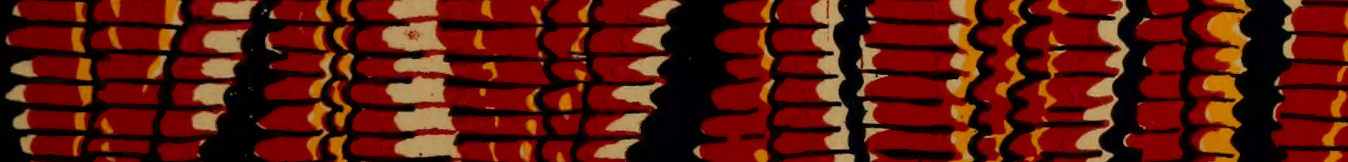

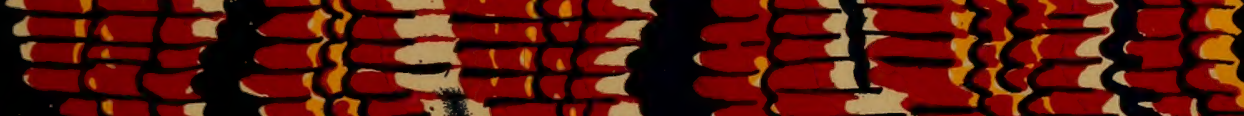

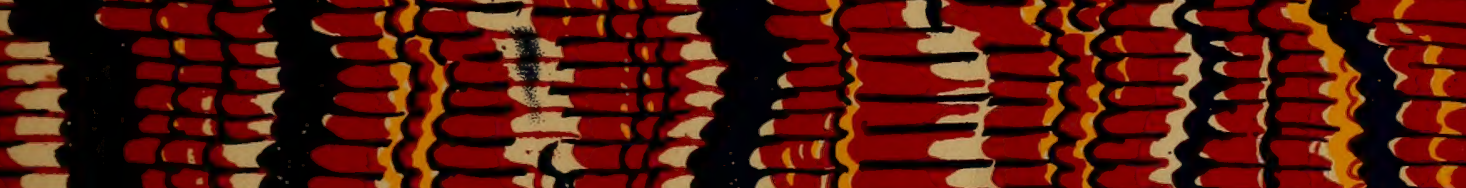

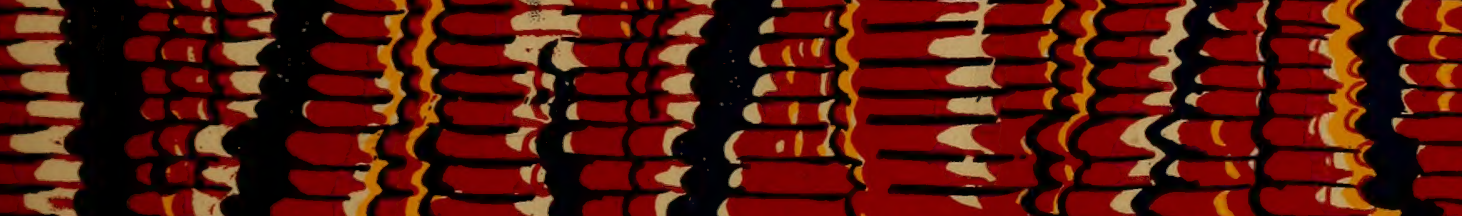

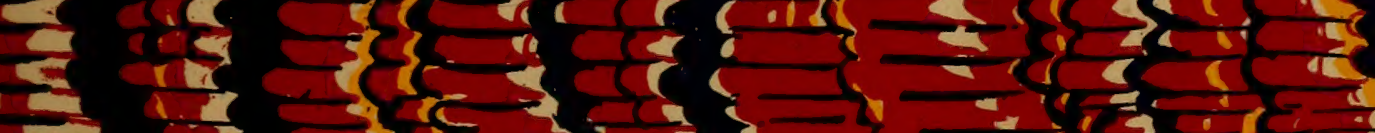

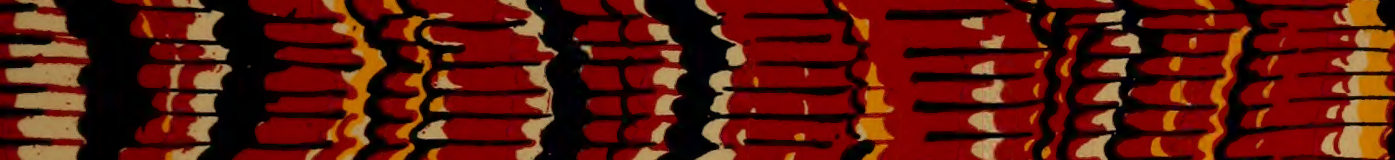

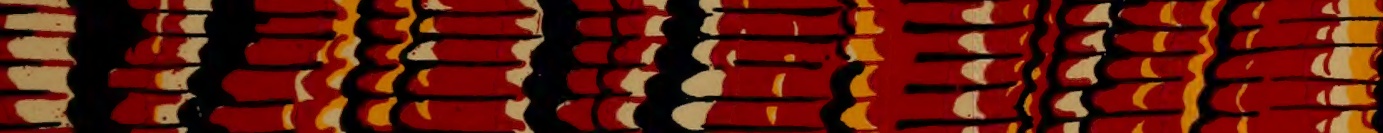

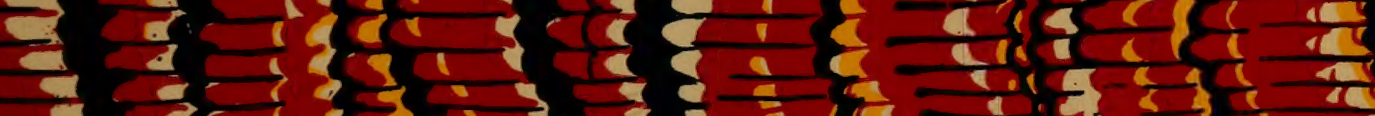

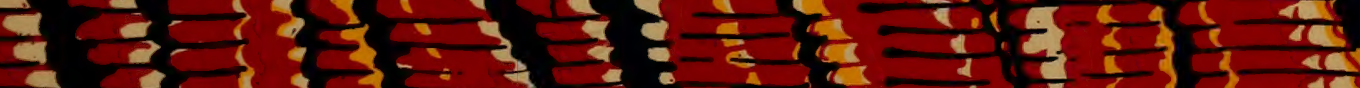
1

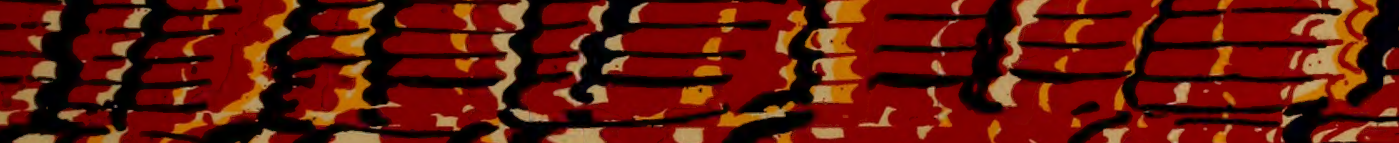

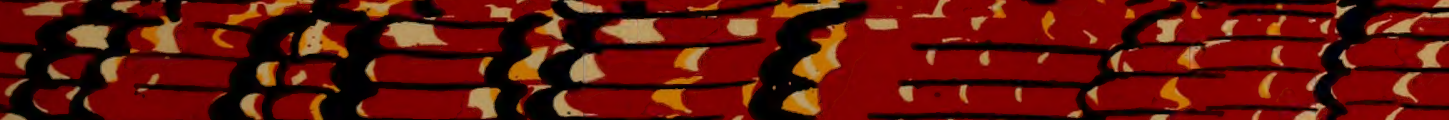

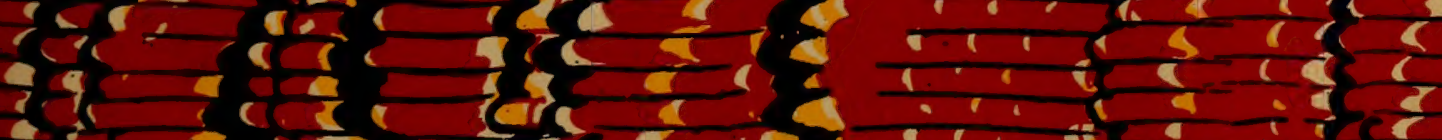

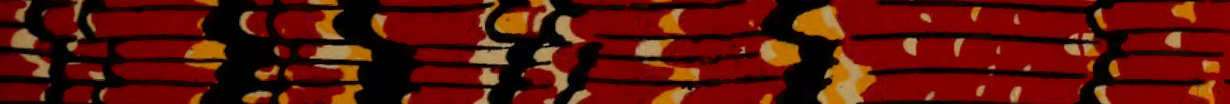

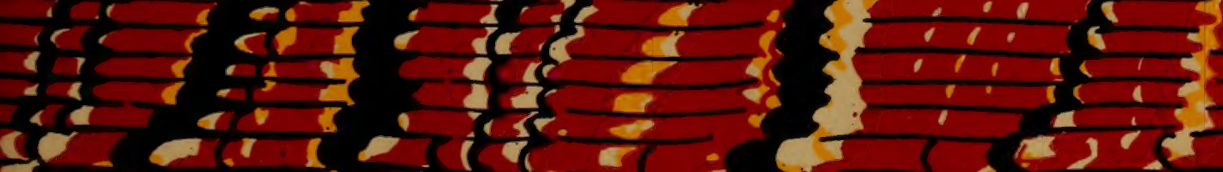

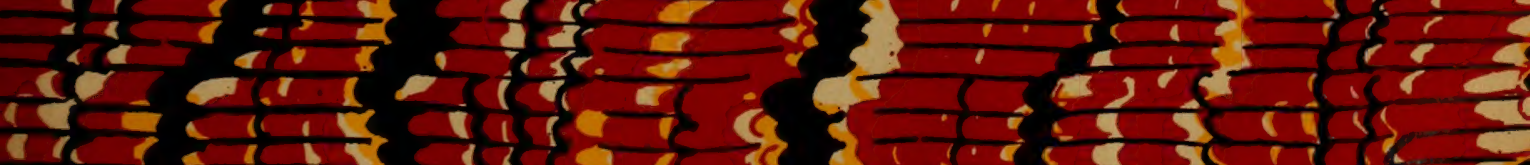

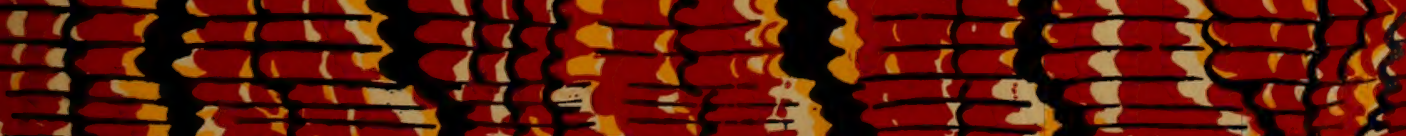

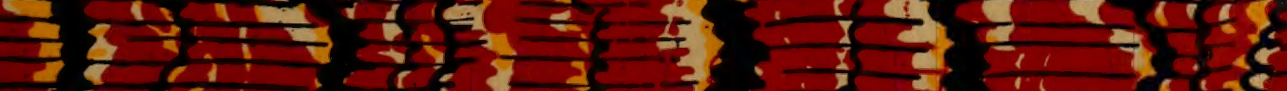



Sent t

Land, fresh-water \& marine crustacean. basin of the river Forth

(Binderies title)

Pte.1-2

1. A catalogue of land, fresh-water, and marine Crustacea found in the basin of the River Forth and its estuary.

Proc. Roy. Phys. Soc. Edinburgh,

Session 1905-1906, Vol. XVI, No. 4, 1906, pp. 97-190, pl. VI.

2. A catalogue of land, fresh-water, and marine Crustacea found in the basin of the River Forth and its estuary. Part II. Proc. Roy. Phys. Soc. Edinburgh,

Session 1905-1906, Vol. XVI, No. 7, 1906, pp. 267386. 277153 



Qni $Q$

441,4

67542

REPRINT FROM THE

1906

PROCEEDINGS

OF THE

ROYAL PHYSICAL SOCIETY OF EDINBURGH. SESSION $1905-1906$.

$$
\text { VOL. XVI.-No. } 4 .
$$

\section{A CATALOGUE OF}

\section{LAND, FRESH-WATER, AND MARINE GRUSTAGEA FOUND IN} THE BASIN OF THE RIVER FORTH AND ITS ESTUARY.

BY

THOMAS SCOTT, LL.D., F.L.S., Mem. Soc. Zool, de France, etc.

EDINBURGH :

Publighed by ROBERT GRANT \& SON, 107 Princks Street.

$$
\text { MDCccovi. }
$$

Price, Three Shillings and Sixpence. 
With the Compliments of

THOMAS SCOTT, LL.D., 280 VICTORIA ROAD, ABERDEEN. 
XIV. A Catalogue of Land, Fresh-Water, and Marine Crustacea found in the Basin of the River Forth and its Estuary. By Thomas Scotт, LL.D., F.L.S., Mem. Soc. Zool. de France, etc. [With Map. Plate VI.]

(Read 27th March 1905.)

\section{PART I.-MALACOSTRACA, CLADOCERA, AND BRANCHIURA.}

\section{INTRODUCTORY REMARKS.}

(1) On the Drainage Area of the Forth. ${ }^{1}$

The river Forth, from its source on the side of Ben Lomond to where it terminates in the estuary near Kincardine-on-Forth, measures about $64 \frac{1}{2}$ miles, and as the length of the estuary is about 48 miles, the total length, from the source of the river to the seaward limits of the estuary, is slightly over 112 miles. Leslie and Herdman describe the Forth estuary as extending to the Vale of Stirling, or about 8 miles farther west than the limit stated here.

The drainage area of the river, including its tributaries, is almost 628 square miles, while that of the estuary is about 1133 square miles, or about 1760 square miles altogether.

The average depth of the estuary scarcely exceeds 15 fathoms. There are one or two places where it reaches to about 40 fathoms, but these are very limited. A considerable portion of the estuary towards its seaward limits ranges from 15 to 30 fathoms in depth; but nowhere is there such deep water as in the Firth of Clyde.

The largest fresh-water lochs within the area are-Loch Katrine, Loch Vennachar, Loch Voil, Loch Lubnaig, and Loch Leven (Kinross). There are a number of smaller lakes, such as Loch Achray, Loch Ard, Lake of Menteith, and others, a few of which, though not yet examined, are

${ }^{1}$ The measurements, etc., given here are obtained chiefly from Part II. of the Twelfth Annual Report of the Fishery Board for Scotland (1894), which contains a map of the catchment-basins of all the Scottish rivers, with explanatory notes, giving the lengths of the various rivers, the areas of each river-basin, and other useful information derived from official sources.

VOL. XVI. 
not expected to add much to what is already known con cerning the fresh-water Crustacea of the district. For : description of the physical geography of the estuary, see the Introduction to Parnell's Fishes of the Firth of Forth, and to Leslie and Herdman's Invertebrate Fauna of the Estuary.

(2) On the History of the Crustacean Fauna of the Forth. Contributions by Sir Robert Sibbald and PROFESSOR JAMESON.

Though Sir Robert Sibbald in 1710, and Professor Jameson in 1809, published lists of Forth Invertebrata which are of much interest, the number of Crustacea recorded by them is small, and consists for the most part of the larger species.

\section{Contributions by Harry Goodsir.}

The interesting field opened up by the researches of Harry Goodsir, and the success that attended his labours, might have directed some attention to the micro-crustacean fauna of the Firth of Forth, but the so-called "stalk-eyed" forms still continued in be the chief object of study. Even Professor Bell, in his work on the British Stalk-eyed Crustacea, could add little to what Goodsir had published on the Schizopoda and Cumacea, but simply transcribed that author's descriptions and drawings.

Contributions by Dr James M'Bain.

The lists of the flora and fauna of the Firth of Forth prepared by Dr James M'Bain, R.N., and which form part of the Appendix to the Rev. Walter Wood's East Neuk of Fife-a local but valuable work on the history and antiquities of that part of Fifeshire, published in 1862marks an important stage in our knowledge of the natural history of the estuary, and, as the author remarks, the lists contained in that work are "more perfect than any which had hitherto been published."

In the list of Crustacea given on pages 375 and 376 of that work, thirty-two species are recorded, the names of which are as follow :- 
Stenorhynchus phalangium, now Macropodia rostrata (cf. Stebbing, History of Crustacea, p. 105).

Inachus Dorsettensis.

Hyas araneus.

, coarctatus.

Eurynome aspera.

Cancer pagurus.

Carcinus monas.

Portunus variegatus.

" depurator.

"marmoreus.

, pusillus.

Pinnotheres pisum.

Atelecyclus heterodon,

now $A$. septemdentatus.

Corystes cassivelaunus.

Lithodes maia.

Pandalus annulicornis,

, P. Montagui.

Pagurus Bernhardus.

, Eupagurus Bernhardus.

" ulidianus,

, Forbesii, young of Eupagurus Bernhardus.

, Hyndmanni,

"laevis, now (?) Eupagurus (or Spiropagurus) sculptimanus.

"Anapagurus Hyndmanni.

Porcellana platycheles.

, , lowis.

" longicornis.

Galathea squamifera.

, strigosa.

"nexa.

Munida Rondeletii,

L/ Homarus vulgarps,

Nephrops norvegicus.

i/ Crangon vulgarls.

Hippolyte varians.

Mysis chamoleon,

, M. bamffia.

, Astacus gammarus.

Dr M'Bain, when compiling his list, appears to have overlooked the discoveries of Harry Goodsir, published in 1843; for, with the exception of the Mysis chamoeleon, all the species recorded belong to the Decapoda. A second omission briefiy noticed here, but which is more fully referred to in the sequel, is that of Calocaris Macandrece, Bell. This curious 
species was obtained by Captain $\mathbf{M}^{*}$ Andrew in the stomach of a haddock captured by him in the Firth of Forth in $1851{ }^{1}$ But the list, notwithstanding these omissions, is of considerable value, as giving a fairly accurate summary of what at that time was known concerning the Crustacea of the Forth estuary.

\section{Contribution by Leslie and Herdman.}

The next important contribution to the literature of the Forth Crustacea is contained in Leslie and Herdman's Invertebrate Fauna of the Firth of Forth, published in 1881. ${ }^{2}$ The authors have not only given the results of a large amount of original research, but they have incorporated, along with their own discoveries, the species recorded by previous observers, so that this work presents the most complete account of the Invertebrata of the estuary published up to that date. The list of Crustacea contained in it, though limited to the two sub-classes Cirripedia and Malacostraca, is considerably extended, and would doubtless have been much larger had the time at the disposal of the authors permitted them to take up the Entomostraca as well; but the animals belonging to this sub-class are, for the most part, microscopic, and on that account, and also because of their great numbers and variety, require a considerable amount of time and patience for their successful study.

Ninety-seven species of Crustacea are recorded in Leslie and Herdman's Catalogue, and they are arranged in the following order :-

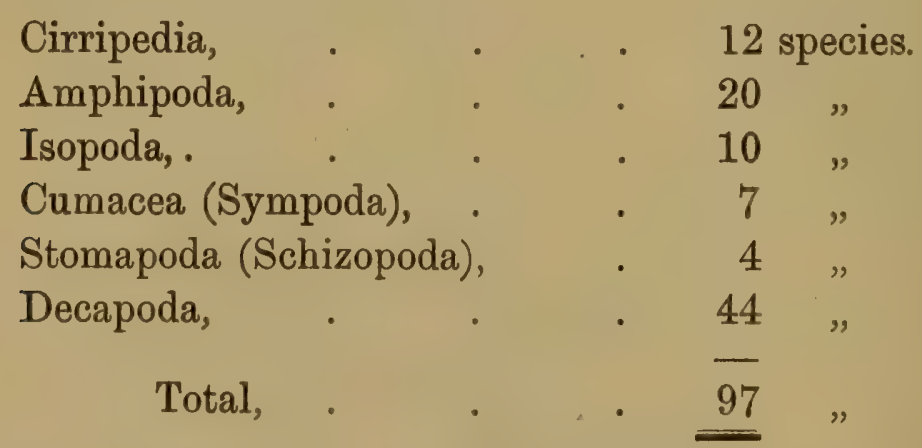

${ }^{1}$ Cf. Hist. of Brit. Crust., by Adam White (British Museum), published 1857, p. 99.

2 Proc. Roy. Phys. Soc., vol. vi, pp. 68-95, 201-231, and 268-315. 
Among the Cirripedia mentioned, one species-Balanus tintinabulum-is, as stated by the authors, "an inhabitant of the warmer seas, and its occurrence in the Forth is an accidental circumstance."

Among the Amphipoda, Caprella lobata, O. F. Müller, is now regarded as synonymous with Caprella linearis (Linn.).

Among the Isopoda, Arcturus (or Astacilla) gracilis, Goodsir, is considered by G. O. Sars to be the young of A. longicornis (Sow.).

Among the Cumacea, Cuma Edwardsi, Goodsir, has been shown to be synonymous with $C$. scorpioides (Montagu).

Among the Schizopoda, Cynthia Flemingi, Goodsir, is considered by Canon A. M. Norman to be probably identical with Leptomysis lingvura, G. O. Sars, and Themisto brevispinosa, Goodsir, to be probably the male of Mysis (Macromysis) flexuosus (Müll.). ${ }^{1}$

Themisto longispinosa, Goodsir, Canon Norman is unable to identify-the description being insufficient.

These and similar changes in arrangement and nomenclature are, however, incidental to the more accurate knowledge we now possess concerning the animals themselves, as well as concerning the discoveries and writings of the earlier authors, but notwithstanding these changes, the work referred to is still indispensable to those who wish to become acquainted with the natural history of the Forth estuary.

\section{Contribution by DR J. R. Henderson.}

A furtber contribution to the natural history of the estuary was made by Dr J. R. Henderson, in a paper read before the Royal Physical Society of Edinburgh in December 1884, entitled, "Recent Additions to the Invertebrate Fauna of the Firth of Forth." The number of species previously recorded was considerably increased, and as Dr Henderson's attention had been devoted chiefly to the Crustacea, the largest number of the additions occurred in this group. They are as follows :-

${ }^{1}$ Cf. Ann. and Mag. Nat. Hist., Sept. 1892, pp. 245 and 251, footnote. 


\section{AMPHIPODA-13 Species, viz:-}

Hyale Nilssoni (Rathke).

Stenothoë pollexiana (Bate), now Metopa norvegica (Lillj.).

Ampelisca aquicornis, Bruzel

Iphimedia obesa, Rathke.

Pherusa bicuspis ${ }^{1}$ (Kröyer), now ? Paramphithoë bicuspis (Kröyer).

" fucicola, Leach, " ?Apherusa Jurinii (M. Edw.).

Calliopiusbidentatus, Norman, now Paramphithoëbicuspis(Kröyer). Aora gracilis, Bate.

Noenia tuberculosa, Bate,

" excavata, Bate,

Corophium tenuicorne, Norman, "Corophium affine, Bruzel.

Hyperia oblivia, Kröyer, , Parathemisto oblivia (Kröyer).

Proto ventricosa, Müll., Phtisica marina, Slabber.

\section{ISOPODA-3 Species.}

Tanais vittatus, Rathke, now Tanais Cavolinii, M. Edw.

Jora albifrons, Leach.

Idotea linearis (Penn.).

Cumacea (Srmpoda) - 1 Species.

Diastylis lavis, Norman (previously recorded in Leslie and Herdman's Invertebrate Fauna as Alaunc rostrata, Goodsir), now Diastylis rostratus (Goodsir). ${ }^{2}$

\section{SchIZopoda-2 Species.}

Nyctiphanes norvegica (M. Sars).

Podopsis Slabberi (V. Ben.), now Macropsis Slabberi.

\section{DeCAPODA-2 Species}

Hippolyte pusiola, Kröyer.

Eupagurus pubescens (Kröyer).

IPherusa bicuspis is Bate's name, not Kroyer's; and though Pherusa bicuspis, Bate, was at one time considered to be synonymous with Kröyer's Amphithoë bicuspis (now Paramphithö̈ bicuspis (Kröyer)), it turns out, on the contrary, to be equivalent to Apherusa bispinosa (Bate).

${ }^{2}$ It is but right to state that though $\mathrm{G}$. O. Sars regards $D$. locvis as identical with $D$. rostratus, Norman does not agree with that opinion (see note under that species). 
It will be observed from the above list that twenty species, exclusive of the Diastylis, were at this time added to the Crustacean fauna of the estuary. Two undescribed species belonging to the Amphipoda were also found by $\mathrm{Dr}$ Henderson in 1884, but were not recorded till 1894; ere that time, however, they had been described by Professor G. O. Sars. They are entered in the present Catalogue under the names of Sthenometopa robusta (G. O. Sars) and Param1 phithoё monocupis, G. O. Sars.

Contributions by the pREsent Writer in the Reports of the Fishery Board for Scotland, etc.

Although various groups of the Crustacea were receiving more attention than formerly, it was not till 1888 that a list of the Forth Entomostraca was published. In that year I contributed a small paper to the Sixth Annual Report of the Fishery Board for Scotland, entitled, "A Revised List of the Crustacea of the Firth of Forth," in which I gave the results of some researches extending over the autumn and winter of 1887, and these included a list of marine Entomostraca. For several years thereafter, my leisure time was devoted chiefly to the study of the Crustacea, and especially of the Entomostraca of the Forth estuary. The work assigned to me by the Fishery Board for Scotland afforded me opportunities for this study such as are seldom enjoyed by the student, and I desire to express my great obligation to the Fishery Board for the many favourable opportunities I have enjoyed for prosecuting the study both of the marine and of the fresh-water Crustacea of Scotland. The results of my researches, under the title of "Additions to the Fauna of the Firth of Forth," were published year by year in the Board's Annual Reports. The last of these papers (No. 8) was published in 1896, in Part III. of the Fourteenth Report. But though no papers have been published since 18.96 dealing exclusively with Forth Crustacea, records of new or rare forms from the Forth have appeared occasionally in subsequent Reports, along with the descriptions of species from other parts of Scotland. Papers on the land and fresh-water 
Crustacea of the district were also contributed by me to the Proceedings of the Royal Physical Society for 1890-94.

Some months ago I decided to collect all the scattered records of Forth Crustacea published by myself in the Annual Reports of the Fishery Board for Scotland and elsewhere, and, adding those published by other writers, or that have been supplied to me by friends interested in the natural history of the district, to prepare a catalogue of the land, fresh-water, and marine Crustacea known to occur within the limits of the basin of the river Forth and of its estuary, in the hope that it might be useful to other students, as former catalogues have been to myself.

Contributions by Professor G. S. Brady, Rev. A. M. Norman, and David Robertson.

In the preparation of this Catalogue, I have been indebted to a paper by Professor G. S. Brady and David Robertson on the "Ostracoda and Foraminifera of Tidal Rivers," and to the excellent monograph of "The Marine and Fresh-Water Ostracoda of the North Atlantic and North-Western Europe" by Brady and Norman, for a considerable number of Forth records of species belonging to that group.

\section{Contribution by Dr and Miss Sprague.}

An excellent paper on the Fresh-Water Crustacea of MidLothian, by Dr and Miss Sprague, published in the Transactions of the Edinburgh Fireld Naturalists and Microscopical Society in 1901, has alsu been very helpful to me.

\section{Contributions by William Evans, F.R.S.E., and Mrs Janet CARPhin.}

Mr Williau Evans, F.K.S.E., Edinburgh, has added one or two interesting species, notably the rare terrestrial Isopod, Platyarthros Hoffmannseggi, to the Crustacean fauna of the Edmburgh district, and has also furnished me with a number 
of additional localities for species already recorded; while Mrs Janet Carphin, in the course of her searches for land and fresh-water Mollusca in the district around Edinburgh, has been successful in capturing in the Union Canal the curious Argulus foliaceus ${ }^{1}$ - a Crustacean which is the only living representative in Scotland of the Branchiura, a suborder of the Branchiopoda.

One of the many discoveries made by my friend the late Mr James Bennie, of the Geological Survey, was the occurrence, near Edinburgh, of numerous remains of Lepidurus (Apus) borealis belonging to the Phyllopoda, which is also a suborder of the Branchiopoda. This discovery is the more interesting, as no living representative of that suborder is now known to occur in the British Islands.

With the assistance of the works referred to, and of friends interested in the natural history of the district, the compilation of this Catalogue has been more a pleasure than a task. It may also be stated that several valuable monographs of special groups of Crustacea published during recent years, have been of much service to me in the systematic arrangement of the species, and though reference to these will be found throughout the Catalogue, a few of the more important of them may be mentioned here, viz.:-

The Crustacea of Norway, by Professor G. O. Sars of Christiania. Four volumes of this great work have already been published, viz.-Vol. I., the Amphipoda; Vol. II., the Isopoda; Vol. III., the Cumacea; and Vol. IV., the CopepodaCalanoida. Vol. V., the Copepoda-Harpacticoida, is at present in course of publication.

Résultats des Campagnes Scientifiques accomplies sur son Yacht par Albert I ${ }^{\text {er }}$ Prince Souverain de Monaco-Fascicule xvi., Amphipodes provenant des Campagnes de l'Hirondelle by Edouard Chevreux.

Contribution a l'étude des Épicarides: les Bopyridce, by M. Jules Bonnier.

Les Copépodes du Boulonnaise, by Dr Eugene Canu.

${ }^{1}$ Ann. Scot. Nat. Hist., October 1895, p. 255. 
Deutschlands freilebende Sïsswasser-Copepoden, by Prof. Otto Schmeil.

Die Asterocheriden des Golfes von Neapel, by Dr W. Giesbrecht, of Naples.

The Choniostomatidoe: A Group of Minute Parasitic Copepoda, by Dr H. J. Hansen.

Cladocera-Suecioc: A Monograph of the Cladocera of Sweden, by Prof. W. Lilljeborg.

Deutschlands Süsswasser-Ostracoden, by Dr G. W. Müller.

Cypriden und Darwinutiden der Schweiz, by Dr A. Kaufmann.

The work by the Rev. T. R. R. Stebbing, F.R.S., entitled $A$ History of Crustacea, has been very helpful to me in the general systematic arrangement of the species, and especially of the Malacostraca.

My son, Mr Andrew Scott, A.L.S., has given me valuable assistance with the identification of the Entomostracan species; and I also am greatly indebted to my friend Mr F. G. Pearcey, for rich collections of micro-Crustacea from the Forth estuary and elsewhere.

The Map which accompanies this part of the Catalogue shows approximately the limits of the basin of the river and its estuary. It also shows approximately the positions of the ten Experimental Stations laid down by the Fishery Board for Scotland in the Firth of Forth, since many of the species recorded here were obtained at one or other of these "Stations." The Stations are marked in Roman numerals: Stn. I., Stn. IV., etc.

In arranging the species, I have followed the classification in Stebbing's Natural History of Crustacea (page 49), in which the Podophthalma have the first place, while the Cirripedia come last.

The following is the order in which the species in this part (Part I.) of the Catalogue are arranged. 


\section{PART I.}

\section{Sub-Class I.-MALACOSTRACA.}

Order 1. Podophthalma, or Stalked-eyed Crustacea.

Suborder Brachyura number of species, 19

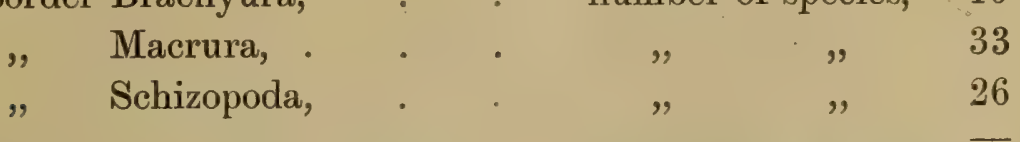

Total number of species belonging to the Podophthalma,

26

Order 2. Edriophthalma, or Sessile-eyed Crustacea.

Suborder Sympoda (Cumacea), number of species, 21

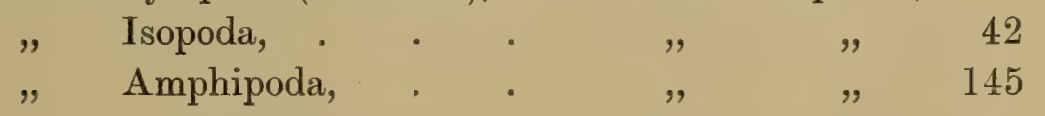

Total number of species belonging to the Edriophthalma, 208

\section{Sub-Class II.-ENTOMOSTRACA.}

Order 3. BRanchiopoda.

Suborder Cladocera, . . number of species, 54

" Branchiura, . . $\quad$, $\quad$ ", 1

Total number of species belonging to the Branchiopoda,

" $\quad$, recorded in this Part,

PART II. will contain a catalogue of species belonging to the Order Ostracoda, of which there are about 132 species, " " COPEPODA, of which there are about 300 " the Sub-Class Cirripedia, of which there are about 13 ", and adding to these the number given above, viz., 341 ",

The total number of species for the Forth at present known is about . . . 786

In compiling this first part, should any species have been overlooked, or should any additional species occur before Part II. is published, they will be noticed in an Appendix to that part. 


\section{Sub-Class I. MALACOSTRACA.}

\section{Order 1. PODOPHTHALMA.}

Suborder Brachyura.1

Family CA N C R I D

\section{Genus (1) Cancer, Linné, 1767.}

\section{Cancer pagurus, Linné.}

1767. Cancer pagurus, Linn., Syst. Nat., ed. xii., vol. i. p. 1044.

Habitat. - Firth of Forth, from inshore to moderately deep water. Specimens have occasionally been captured in the trawl-net of the Fishery steamer "Garland," at all the experimental stations from above Queensferry to the mouth of the estuary.

\section{Family PORTUNID 瓜.}

Genus (2) Carcinus, Leach, 1813.

2. Carcinus moenas (Linné).

1767. Cancer moenas, Linn., Syst. Nat., ed, xii., vol. i. p. 1043.

Habitat.-Common everywhere between tide-marks, especially where the shore is rough and provides suitable shelter; also occasionally found in moderately deep water.

\section{Genus (3) Portunus, Fabricius, 1798.}

3. Portunus puber (Linné).

1767. Cancer puber, Linn., Syst. Nat., ed. xii., vol. i. p. 1046.

Habitat.-Taken at the mouth of the estuary on deep-sea lines (Leslie and Herdman). This appears to be, so far, the only published record of this species for the Firth of Forth.

4. Portunus depurator (Linné).

1767. Cancer depurator, Linn., Syst. Nat., ed. xii., vol. i. p. 1043.

Habitat.-Common throughout the estuary, and frequently associated with $P$. holsatus.

${ }^{1}$ In the nomenclature of this suborder, Bell's British Stalk-eyed Crustacea, 1853 , has been generally followed. 


\section{Portunus holsatus, Fabricius.}

1798. Portunus holsatus, Fabr., Ent. Syst., Suppl., p. 336.

Habitat.-Firth of Forth (Dr Leach, as P. lividus). Commonly met with on the oyster-banks (Henderson). ${ }^{1}$ Firth of Forth (White, 1857). One of the more common of the Forth Brachyuræ, but is not mentioned in Wood's List.

\section{Portunus marmoreus, Leach.}

1814. Portunus marmoreus, Leach, Malacol. Brit., pl. viii.

Habitat.-At Portobello and Musselburgh, found occasionally on the beach (Howden; L. \& H.). Obtained amongst trawl refuse west of May Island (Mihi).

\section{Portunus pusillus, Leach.}

1814. Portunus pusillus, Leach, op. cit., pl. ix. figs. 5-8.

Habitat.-Off Prestonpans (Howden). Firth of Forth, common (Norman; cf. White, Brit. Crust., 1857, p. 52). Leslie and Herdman say they have frequently dredged this species near Inchkeith (Invert. Fauna, p. 51). I have occasionally observed $P$. pusillus amongst the trawl refuse when at work in Largo Bay.

\section{Genus (4) Portumnus, Leach, 1814.}

\section{Portumnus latipes (Pennant).}

1777. Cancer latipes, Pennant, Brit. Zool., vol. iv. p. 5, pl. i. fig. 4. 1853. Portumnus variegatus, Bell, op. cit., p. 85.

Habitat.-At Prestonpans and Port Seton (Howden). Shores of the Firth of Forth (White, Brit. Crust., p. 43). Portobello (Leslie and Herdman). Sandy shore near Gullane (Andrew Scott). Aberlady, 1890 (W. Evans).

Family CORYSTID $\mathbb{E}$.

Genus (5) Corystes, Latreille, 1802.

9. Corystes Cassivelaunus (Pennant).

1777. Cancer Cassivelaunus, Pennant, Brit. Zool., vol. iv. p. 6, pl. vii. Habitat.-Off Inchkeith (M'Bain). Newhaven (C. W.

1 "Decapod and Schizopod Crustacea of the Clyde," Trans. Nat. Hist. Soc. Glasgow (1886), p. 10. 
Peach). Near the Bass Rock (Metzger). Firth of Forth (Edin. Mus.). Aberlady and Kirkcaldy Bays (Leslie and Herdman). Aberlady and Portobello (W. Evans). I have occasionally observed this species among the trawl refuse when at work with the Fishery cruiser "Garland."

Genus (6) Atelecyclus, Leach, 1813.

10. Atelecyclus septemdentatus (Montagu).

1815. Cancer (Hippa) septemdentatus, Mont., Trans. Linn. Soc., vol. xi., pl. i. fig. 1.

1853. Atelecyclus heterodon, Bèll, op. cit., p. 153.

Habitat.-Firth of Forth, rare (Goodsir). Firth of Forth (Edin. Mus.). Beach at Portobello (M'Bain). Found in the stomach of a cod-fish (Dr J. A. Smith, ${ }^{1}$ and Leslie and Herdman). I have obtained $A$. septemdentatus on one or two occasions.

\section{Family PIN N OTHER I D}

Genus (7) Pinnotheres, Latreille, 1802.

\section{Pinnotheres pisum (Linné).}

1767. Cancer pisum, Linn., Syst. Nat., ed. xii., vol. i., part 2, p. 1039.

Habitat.-Taken off Longniddry and elsewhere (Leslie and Herdman). I have occasionally obtained living specimens - male and female-in the shells of large horse-mussels (Mytilus modiolus). Two females from M. modiolus, Prestonpans, Feb. 1905 (W. Evans).

Family MACHID.

Genus (8) Macropodia, Leach, 1814.

12. Macropodia rostrata (Linné).

1767. Cancer rostratus, Linn., Syst. Nat., ed. xii., vol. ii. p. 1014.

1853. Stenorynchus Phalangium, Bell, op. cit., p. 13.

Habitat.-Firth of Forth, at Prestonpans (Edin. Mus.). Both Howden, and Leslie and Herdman record this species,

${ }^{1}$ Cf. Proc. Roy. Phy. Soc. Edin., vol, iii. p. 214. 
and describe it as generally distributed where the bottom consists of mud and sand. I have frequently obtained it in the neighbourhood of Inchkeith, and off Musselburgh. North Berwick, 1895 (W. Evans).

\section{Genus (9) Inachus, Fabricius, 1798.}

13. Inachus dorsettensis (Pennant).

1777. Cancer dorsettensis, Penn., Brit. Zool., vol. iv. p. 12, pl. x. fig. 1.

Habitat.-Howden records obtaining this species on fishermen's deep-sea lines, but no locality is given.

\section{Inachus leptochirus, Leach.}

1815. Inachus leptochirus, Leach, Malac. Brit., pl. xxii., в.

Habitat.-Firth of Forth (Rev. G. Gordon; cf. White's Popular Hist. Brit. Crust. (1857), p. 19).

Family M A I D A.

Genus (10) Hyas, Leach, 1813.

\section{Hyas araneus (Linné).}

1746. Cancer araneus, Linn., Fauna Suecica, p. 2030.

Habitat.-Firth of Forth, common in the littoral and laminarian zones.

16. Hyas coarctatus, Leach.

1815. Hyas coaretatus, Leach, Trans. Linn. Soc., vol. xi. p. 329.

Habitat.-Moderately common in the Firth of Forth, especially in the deeper water.

Family PARTHENOPID E.

Genus (11) Eurynome, Leach, 1814.

17. Eurynome aspera (Pennant).

1777. Cancer asper, Penn., Brit. Zool., vol. iv. p. 13, pl, x. fig. 3.

Habitat.-Taken off Prestonpans and Port Seton (Howden). 
Family LEUCOSIID

Genus (12) Ebalia, Leach, 1817.

18. Ebalia tuberosa (Pennant).

1777. Cancer tuberosa, Penn., Brit. Zool., vol. iv. p. 19, pl. ix. fig. $a-f$.

1853. Ebalia Pennantii, Bell, op. cit., p. 141.

Habitat.-Dredged off the west side of May Island, on moderately hard ground, scarce (Mihi).

19. Ebalia Cranchi, Leach

1815. Ebatia Cranchi, Leach, Zool. Miscellany, vol. ii. p. 20.

Habitat.-Firth of Forth (Goodsir). Dredged twice in 25 fathoms about $2 \frac{1}{2}$ miles off Dunbar (F. M. Balfour; cf. Leslie and Herdman, Appendix, p. 106).

\section{Suborder Macrura.}

Family L I T H O I D

Genus (1) Lithodes, Latreille, 1806.

1. Lithodes maia (Linné).

1767. Cancer maia, Linn., Syst. Nat, ed. xii., vol. ii. p. 1046.

Habitat.-Firth of Forth (Howden). Dr Neil obtained young specimens in the stomach of a cod-fish. Leslie and Herdman state that Lithodes is not uncommon near the mouth of the estuary. It has been taken, though sparingly, with the "Garland's" trawl-net off the east and west sides of May Island.

Family PAGURID

Genus (2) Eupagurus, Brandt, 1851.

2. Eupagurus bernhardus (Linné).

1767. Cancer bernhardus, Linn., Syst. Nat., ed. xii., vol. ii. p. 1049.

1853. Pagurus bernhardus, Bell, op. cit., p. 171.

Habitat.-Common in the Firth of Forth. The form recorded by Howden under the name of $P$. ulidianus, is regarded as a small or young $E$. bernhardus. ${ }^{1}$

${ }^{1}$ History of Crustacea, by Rev, T. R. R. Stebbing (1893), p. 161. 
3. Eupagurus cuanensis (W. Thompson).

1843. Pagurus cuanensis, W. Thomp., Brit. Assoc. Report (1843), p. 267.

Habitat.-Firth of Forth, occupying the shell of a Turretella (F. M. Balfour). This species is apparently rare in the Forth estuary.

\section{Eupagurus pubescens (Kröyer).}

1838. Pagurus pubescens, Kröyer, Consp. Crust. Grönl., Naturh. Tidsskr., ser. i., ii. p. 251.

1853. " Thompsoni, Bell, op. cit., p. 372.

Habitat.-Taken west of May Island in 20 fathoms (Henderson). East of Inchkeith, 9 to 10 fathoms; apparently rare.

\section{[5. Eupagurus sculptimanus (Lucas).}

1843. Pagurus sculptimanus, Lucas, Explo. Scient. de l'Algerie, I. Crust., p. 32, pl. iii. fig. 6 .

1853. ,, Forbesii, Bell, op. cit., p. 186.

Habitat.-Dr Howden has recorded Pagurus (Spiropagurus) Forbesii from the Forth estuary; but Stebbing, in his History of Crustacea, p. 161, regards this as synonymous with Eupagurus sculptimanus, Lucas, the occurrence of which in the Forth is somewhat doubtful. $\left.{ }^{1}\right]$

Genus (3) Anapagurus, Henderson, 1886.

6. Anapagurus Hyndmanni (Thompson).

1843. Pagurus Hyndmanni, Thomp., Brit. Assoc. Report (1843), p. 267.

1886. Anapagurus Hyndmanni, Henderson, Decap. and Schiz. Crust. of the Clyde, p. 27.

Habitat.-Off Musselburgh and Prestonpans (Howden). I have occasionally obtained this species amongst the trawl refuse of the Fishery steamer "Garland."

${ }^{1}$ It is probable that a critical study of the smaller hermit crabs of the Forth estuary might show that some that are regarded as forms of common species may turn out to be distinct.

VOL. XVI. 
7. Anapagurus loevis (Thompson).

1843. Pagurus loevis, Thomp., Brit. Assoc. Report (1843), p. 267.

1886. Anapagurus lavis, Henderson, op. cit., p. 28.

Habitat.-Firth of Forth (Howden). This species is of more frequent occurrence than the last; I have taken it both with the dredge and amongst trawl refuse, in different parts of the estuary.

Family POR C EL L A I D A.

Genus (4) Porcellana, Lamarck, 1801.

8. Porcellana longicornis (Linné).

1767. Cancer longicornis, Linn., Syst. Nat., ed. xii., vol. ii. p. 1040.

Habitat.-Moderately common, and generally distributed.

9. Porcellana platycheles (Pennant).

1777. Cancer platycheles, Penn., Brit. Zool, , vol. iv. p. 9, pl. iv. fig. 2.

Habitat.-Taken at Crail and Fifeness at low-water (Howden). At Elie, and near North Berwick (Leslie and Herdman).

Family GALA T H E I D Æ.

Genus (5) Galathea, Fabricius, 1793.

10. Galathea squamifera, Leach.

1815. Galathea squamifera, Leach, Edin. Encycl,, vol. vii. p. 398.

Habitat.-Firth of Forth, moderately common (cf. Leslie and Herdman). In rock pools at North Berwick, January 1896 (W. Evans).

11. Galathea nexa, Embleton.

1834. Galathea nexa, Embl., Trans. Berw. Nat. Club, vol, i. p. 69. Habitat.-Off Port Seton (Howden).

12. Galathea dispersa, Spence Bate.

1859. Galathea dispersa Bate, Proc. Linn. Soc. (Zool.), vol. iii. p. 3.

Habitat-Conmon "on the so-called oyster-banks" (Henderson). ${ }^{1}$

${ }^{1}$ Cf. "Decapod and Schizopod Crustacea of the Clyde," Trans. Nat. Hist. Soc. Glasgow (1886), p. 10. 
13. Galathea intermedia, Lilljeborg.

1851. Galathea intermedia, Lillj., Ofvers Vet.-Akad. Forhandl., p. 21

1857. ", Andrewsii Kinah., Proc. Nat. Hist. Soc. Dublin, vol. ii. p. 58, pl. xvi. fig. 8.

Habitat.-Firth of Forth (Dr Anderson). ${ }^{1}$

14. Galathea strigosa (Linné).

1767. Cancer strigosa, Linn., Syst. Nat., ed. xii., vol. ii. p. 1052.

Habitat.-Off the Bass Rock (Howden). Taken near Dunbar (Robert Gray). I have obtained one or two specimens of this species while at work on the Fishery steamer "Garland," but it did not appear to be very common in the estuary. North Berwick 1895, one specimen (W. Evans).

Genus (6) Munida, Leach, 1820.

15. Munida bamffia (Pennant).

1777. Astacus Bamffius, Pennant, Brit. Zool., vol. iv. p. 17, pl. xiii. fig. 25.

1853. Munida Rondelettii, Bell, op. cit., p. 208.

Habitat.-Not uncommon at Dunbar (Robert Gray). Mr Evans informs me that in January 1896, Mrs Rickards, North Berwick, showed him several specimens which had been obtained there.

\section{Family THA UMAST OCHELIDE.}

Genus (7) Calocaris, Bell, 1853.

16. Calocaris Macandreo, Bell.

1853. Calocaris Macandrece, Bell, op. cit., p. 233.

Habitat.-Adam White, in his Popular History of British Crustacea (1857), p. 99, states that Calocaris was "found by Mr M'Andrew in Loch Fyne and the Mull of Galloway; and subsequently, when dredging in the Firth of Forth in 1851, he got a quantity of haddocks, the stomach and intestines of one of which were filled with it."

Calocaris does not appear to have again been observed in the Forth estuary till 1901, when it was obtained by $\mathrm{Mr}$

${ }^{1}$ Cf. Proc. Roy. Phys. Soc. Edin., vol. i. p. 415. 
F. G. Pearcey, while engaged with some special work on board the Fishery steamer "Garland." On this occasion it was obtained by him among the refuse of the trawl-net, and in the stomachs of a Long Rough Dab and one or two Witch Soles. White's record of the occurrence of Calocaris in the Forth seems to have been overlooked by subsequent writers on the Crustacea of the estuary.

\section{Family NEPHROPID E.}

Genus (8) Nephrops, Leach, 1819.

17. Nephrops norvegicus (Linné).

1767. Cancer norvegicus, Linn., Syst. Nat., ed. xii., vol. ii. p. 1053.

Habitat.-Common, especially in the seaward part of the estuary. Two fine specimens at water's edge, Gullane Point, 2nd May 1890 ; one cast up during storm at Prestonpans, October 1898 (W. Evans).

Genus (9) Astacus, Leach, 1814.

18. Astacus gammarus (Linné).

1761. Cancer Gammarus, Linn. Faun. Suec., 2nd ed., p. 2033.

1853. Homarus vulgaris, Bell, op. cit., p. 242.

Habitat.-Frequent in Firth of Forth. Lobsters in considerable numbers are captured by fishermen where the coast-line is rocky, and especially about the seaward limits of the estuary.

\section{Tribe CARIDEA.}

Family CRANGONID E.

Genus (10) Crangon, Fabricius, 1798.

19. Crangon vulgaris, Fabricius.

1798. Crangon vulgaris, Fabr,, Ent. Syst., Suppl., p. 410.

Habitat.-Common in the littoral zone where the shore is sandy; taken occasionally with the dredge in moderately deep water. 
20. Crangon Allmani, Kinahan.

1857. Crangon Allmanni, Kinahan, Proc. Nat. Hist. Soc. Dublin, vol, iv. p. 80.

Habitat.-Moderately common in the deeper-parts of the estuary; it is also obtained occasionally in shallow water inshore. In 1862 Kinahan instituted a new genus (Steirocrangon) for this species, but subsequent authors do not consider the characters on which the new genus is founded as sufficient to separate it from Crangon.

21. Crangon nanus, Kröyer.

1842. Crangon nanus, Kröyer, Naturh.Tidsskr.(ser. i.), vol,iv. p. 231. 1853. ", bispinosa, Bell, op. cit., p. 268.

Habitat.-Taken near the Bass Rock (Metzger, German Exploring Expedition, 1872). I have obtained it in midchannel east of May Island, off Prestonpans, off the west side of Inchkeith, and in Largo Bay.

22. Crangon trispinosus, Hailstone.

1835. Pontophilus trispinosus, Hailstone, Mag. Nat. Hist., vol. viii. p. 261, fig. 25 .

1853. Crangon trispinosus, Bell, op. cit., p. 265.

Habitat.-Firth of Forth, not common (Mihi).

23. Crangon neglectus (G. O. Sars).

1882. Cheraphilus neglectus, G. O. Sars, Chr. Vidensk. Forhandl., p. 45 , pl. i. fig. 7 .

Habitat.-Dredged in Largo Bay, 1890, rare (cf. Ninth F. B. Rept., pl. iii., p. 309).

24. Crangon fasciatus, Risso.

1816. Crangon fasciatus, Risso, Hist. Nat. Crust. de Nice, p. 82 , pl. iii. fig. 5 .

Habitat.-Off Musselburgh, September 1891, rare (cf. Ann. Scot. Nat. Hist., 1902, p. 228).

\section{Family N I K I D}

Genus (11) Nika, Risso, 1816.

25. Nika edulis, Risso.

1816. Nika edulis, Risso, Crust. de Nice, p. 85, pl. iii. fig. 3.

Habitat.-Taken at the mouth of the estuary by tow-net, rare. 
Family H I P P OLYTID

Genus (12) Hippolyte, Leach, 1813.

26. Hippolyte varians, Leach.

1813. Hippolyte varians, Leach, Edin. Encycl., vol, vii. p. 432.

Habitat.-In shore pools (Howden). Frequent in tidal pools west from Granton. Off the west side of May Island. $H$. fascigera, Gosse, which is now considered to be only a form of $H$.varians, has been taken at Cramond Island at the edge of low-tide.

Genus (13) Spirontocaris, Spence Bate, 1888.

27. Spirontocaris spinus (Sowerby).

1805. Cancer spinus, Sowerby, Brit. Miscellany, p. 47, pl. xxiii.

1853. Hippolyte spinus, Bell, op. cit., p. 284.

Habitat.-Common in the littoral and laminarian zones (Leslie and Herdman). I have occasionally obtained specimens in different parts of the estuary. S. securifrons (Norman), which differs chiefly in having the dorsal aspect of the abdomen even instead of the third segment terminating in a strong posterior dorsal tooth, is also occasionally obtained, but is regarded as a variety of the other.

28. Spirontocaris pusiolus (Kröyer).

1842. Hippolyte pusiola, Kröyer, Monogr. Fremst. of Hippol. Nord. Arter, Vid. Sel. naturvid. og mathem. Afh., ix Deel., p. 319, tab. iii. figs. 69-73.

Habitat.-Newhaven, from the fishermen's lines (Henderson). I have dredged S. pusiolus west of Queensferry, in the neighbourhood of Inchkeith, off Musselburgh, and off St Monans. This is probably the species referred to by Dr Howden as being common off Crail. ${ }^{1}$

29. Spirontocaris Cranchii (Leach).

1815. Hippolyte Cranchii, Leach, Malacol. Brit., p. 38, figs. 17-21.

Habitat.-Rocks off Broxmouth, near Dunbar (F. M. Balfour; in Leslie and Herdman's, Invert. Fauna of Firth of Forth, p. 106).

${ }_{1}^{1}$ Cf, A. White, Hist. of Brit. Crust., p. 122. 
Land, Fresh-Water, and Marine Crustacea.

30. Spirontocaris Gaimardi (M.-Edwards).

1837. Hippolyte Gaimardi, M.-Edw., Hist. Nat. des Crust., vol. ii. p. 378 .

1853. " pandaliformis, Bell, op. cit., p. 294.

Habitat.-Above Queensferry, and at one or two other parts of the estuary; not common.

\section{Family PAN D A I D Æ.}

Genus (14) Pandalus, Leach, 1814.

31. Pandalus Montagui, Leach.

1815. Pandalus Montagui, Leach, Malacol. Brit., pl. xl.

1853. , annaticornis, Bell, op. cit., p. 297.

Habitat.-Firth of Forth, common, and generally distributed.

Genus (15) Pandalina, Calman, 1899.

32. Pandalina brevirostris (Rathke).

1837. Pandalus brevirostris, Rathke, Mem. présenté a l'Acad, de Petersb., t. iii.

1853. Hippolyte Thompsoni, Bell, op. cit., p. 290.

Habitat.-Firth of Forth (F. M. Balfour). I have obtained this species off the west side of Inchkeith, off Musselburgh, between Fidra and the Bass Rock, and in mid-channel west of May Island, but always sparingly.

Family PAL \& ONID Æ.

Genus (16) Leander, Desmarest, 1849.

33. Leander squilla (Linné).

1767. Cancer squilla, Linn., Syst. Nat., ed. xii., vol. ii. p. 1051.

1853. Palcemon squilla, Bell, op. cit., p. 305.

Habitat.-In rock pools near the mouth of the estuary, frequent (Leslie and Herdman). In rock pools, North Berwick, rather common, August 1897 (W. Evans).

\section{Suborder Schizopoda.}

For this group I have followed the arrangement and nomenclature of the Rev. Canon Norman's "Revision of the British Species of Schizopoda," published in Ann. and Mag. 
Nat. Hist., Ser. 6, vol. ix. pp. 454-464, and Ser. 6, vol. x. pp. 143-166, and 241-263, 1892.

\section{Family E U P H A U S I I D A.}

Genus (1) Nyctiphanus, G. O. Sars, 1883.

1. Nyctiphanus norvegica (M. Sars).

1856. Thysanopoda norvegica, M. Sars, Forhandl. Scand. Naturf. Möde i Chr., p. 169.

Habitat.-Firth of Forth, young specimens not uncommon (Henderson). ${ }^{1}$ Nyctiphanes was usually scarce in our townet collections, but it appears to be scarcer some years than others.

Genus (2) Rhoda, G. Sim, 1872.

2. Rhoda Raschi (M. Sars).

1863. Thysanopoda Raschi, M. Sars, op. cit., p. 7.

1872. Rhoda Jardineana, G. Sim, Scottish Naturalist, vol. i. p. 187, pl, iv, fig. A.

1883. Boreophausia Raschi, G. O. Sars, Chr. Vid.-Selsk. Forhandl., No. 7, p. 11.

Habitat.-Firth of Forth, moderately frequent, and generally distributed.

3. Rhoda inermis (Kröyer).

1849. Thysanopoda inermis, Kröyer, Voyage in Scand., Crust., pl. vii. fig. 2, $a-t$.

Habitat.-Firth of Forth, captured in 1892 and 1894.

Genus (3) Thysanoessa, F. Brandt, 1851.

4. Thysanoessa neglecta (Kröyer).

1849. Thysanopoda neglecta, Kröyer, op. cit., pl. vii. fig. 3, $a-d$.

1872. Thysanoessa aberdonensis, G. Sim, Scottish Naturalist, vol. i. p. 188 , pl. v. figs. $1-8$.

Habitat.-Firth of Forth, frequent.

5. Thysanoessa longicaudata (Kröyer).

1849. Thysanopoda longicaudata, Kröyer, op. cit., pl. viii. fig. 1, $a-f$.

Habitat.-Firth of Forth, off St Monans, 1891; a few

1 "Decapod and Schizopod Crustacea of the Clyde," Trans. Nat. Hist. Soc. Glasgow (1886), p. 38. 
specimens were obtained mixed up with $T$. neglecta. $T$. longicaudata is very similar in general appearance to the more common $T$. neglecta, and therefore it may have occasionally been overlooked.

Genus (4) Nematoscelis, G. O. Sars, 1883.

6. Nematoscelis megalops, G. O. Sars.

1872. Thysanoessa borealis, Norman, M. S., in Sim, Stalk-eyed Crust. N.E. Coast of Scotland; Scottish Naturalist, vol. i. p. 188.

1883. Nematoscelis megalops, G. O. Sars, Chr. Vid.-Selsk. Forhandl., p. 27.

Habitat.-Firth of Forth, 1892 [see Norman in Ann. and Mag. Nat. Hist. (June 1892), p. 464]. Off St Monans, one specimen, 28th May 1904.

Family M Y S I D Æ.

Genus (5) Siriella, Dana, 1850.

7. Siriella norvegica, G. O. Sars.

1869. Siriella norvegica, G. O. Sars, Undersögelser over Christianiafjorden, Dybrandsfauna, p. 40.

Habitat.-Firth of Forth, near May Island, 1889, rare.

8. Siriella jaltensis (Czerniavsky).

1868. Siriella jaltensis, Czern., Materialia ad Zoographiam Ponticam comparatam, p. 66, pl. iv. figs. 12 and 13.

Habitat.-Taken at Joppa, September 1887, and subsequently at various other places, but always sparingly. The latest record I have is for Station V., where one or two specimens were captured on 24th April 1901.

9. Siriella armata (M.-Edwards).

1837. Cynthia armata, M.-Edwards, Hist. Nat. des Crust., vol. ii. p. 436.

Habitat.-Taken off St Monans in February 1889, and at Station III. in March 1892 . It also occurred sparingly in the same gathering with $S$. jaltensis from Station V. collected in April 1901. This Siriella has been observed in the Forth estuary more frequently than any of the other members of the genus. 
Genus (6) Gastrosaccus, Norman, 1869.

10. Gastrosaccus spinifer (Goës).

1863. Mysis spinifer, Goës, Öfvers K. Vet.-Akad. Handl., vol. xx. p. 14.

1872. Acanthocaris Livingstoniana, G. Sim, Scottish Naturalist, vol. i. p. 185, pl. iv. fig. B, 1-7.

Habitat.-Obtained frequently in surface tow-net gatherings collected off Bo'ness in 1887-88, and subsequently at various places throughout the estuary.

Genus (7) Heteromysis, S. I. Smith, 1873.

11. Heteromysis formosa, S. I. Smith.

1873. Heteromysis formosa, Smith, U.S.A., Fish and Fisheries Comm. Rept., 1871-72, p. 553.

Habitat.-One or two specimens were captured off the east side of Inchkeith in October 1888. Taken also at Station I. in August 1894, and at Station IV. on 27th February 1895.

Genus (8) Erythrops, G. O. Sars, 1870.

12. Erythrops erythrophthalmus (Goës).

1863. Mysis erythrophthalmus, Goës, Crust. Decap. Marina Suecicæ, p. 18.

1870. Erythrops Goësii, G. O. Sars, Carcin. Bidrag til Norges Fauna, I. Monogr. Mysider, p. 24, pl, i.

Habitat.-Frequent in all parts of the estuary between Inchkeith and May Island, especially during the winter and spring.

13. Erythrops elegans, G. O. Sars.

1863. Nematopus elegans, G. O. Sars, Beret. om en i Somm. 1862 foret. zool. Reise i Chr. oy Throndhjems Stifter, p. 42.

Habitat.-Firth of Forth, 1901, taken very sparingly on one or two occasions.

14. Erythrops serratus, G. O. Sars.

1870. Erythrops serratus, G. O. Sars, Monogr. Mysider (I.), p. 27, pl. ii. figs. 1-12.

Habitat.-Obtained in 1889 in the neighbourhood of the Bass Rock, rare. 
Genus (9) Mysidopsis, G. O. Sars, 1864.

15. Mysidopsis didelphys (Norman).

1863. Mysis didelphys, Norman, Trans. Tyneside Nat. Field Club, vol. 5, p. 270, pl. xii. figs. 9-11.

1872. Mysidopsis didelphys, G. O. Sars, Monogr. Mysider (II.), p. 20, pl. vii.

Habitat.-Taken in the Firth of Forth in November 1888, and subsequently on various occasions, and in different parts of the estuary, but always sparingly.

16. Mysidopsis gibbosa, G. O. Sars.

1864. Mysidopsis gibbosa, G. O. Sars, Zool. Reise 1863, i Christiania Stifter, p. 28.

Habitat.-Firth of Forth, frequent. It has been taken in Granton Harbour, as well as at several of the Experimental Stations (cf. Sixteenth F. B. Rept., pt. iii. p. 209, 1898).

17. Mysidopsis angusta, G. O. Sars.

1864. Mysidopsis angusta, G. O. Sars, Zool, Reise 1863, i Chr. Stifter, p. 30.

Habitat.-Captured very sparingly at Stations I., III., and V., not more than one or two specimens being obtained in any single gathering.

Genus (10) Leptomysis, G. O. Sars, 1869.

18. Leptomysis gracilis, G. O. Sars.

1864. Mysis gracilis, G. O. Sars, Zool. Reise 1863, i Chr. Stifter, p. 23.

1869. Leptomysis gracilis, idem, Undersögelser over Christianiafjordens, Dybvandsfauna, p. 29.

Habitat.-Captured off the east side of Inchkeith, off St Monans, and in the vicinity of Fidra, in October and November 1888, and subsequently at nearly all the Experimental Stations.

19. Leptomysis lingvura, G. O. Sars.

? 1842. Cynthia Flemingii, Goodsir, Edin. New Phil. Jour., vol. xxxiii. p. 175, pl. ii. fig. 1 .

1866. Leptomysis lingvura, G. O. Sars, Zool. Reise 1865, i Chr. Stifter, p. 21.

Habitat.-Obtained in a tow-net gathering collected off 
Joppa in September 1887; off the east side of Inchkeith in March 1892, and also in other parts of the estuary, but always very sparingly.

Genus (11) Hemimysis, G. O. Sars, 1869.

20. Hemimysis Lamornce (Couch).

1856. Mysis Lamornoe, Couch, The Zoologist, p. 5286.

Habitat.-Collected off Bo'ness in November 1887; Largo Bay, December 1888; and afterwards at nearly all the Experimental Stations. This species, when living, is readily observed by its brilliant red colour.

Genus (12) Macropsis, G. O. Sars, 1876.

21. Macropsis Slabberi (Van Beneden).

1860. Podopsis Slabberi, Van Ben., Rech. sur la faune litt. de Belgique, Crust., p. 18, pl. vi.

1876. Macropsis Slabberi, G. O. Sars, Middelhavets Mysider, p. 28, pls. xi.-xiii.

Habitat.-Firth of Forth below Grangemouth, 1884, and subsequently near Granton Quarry, Inchmickery, and Inchkeith (Henderson). Common off Bo'ness and off Musselburgh, but becoming gradually scarcer seaward, and rarely taken at the mouth of the estuary.

\section{Genus (13) Macromysis, White, $1847 .^{1}$}

22. Macromysis flexuosus (O. F. Müller).

1788. Cancer flexuosus, Müll., Zoologia Danica,_Discript. et Hist., vol. ii. p. 34, pl. Jxiv. figs. 1-9.

1853. Macromysis chamceleon, Bell, Brit. Stalk-eyed Crust., p. 336.

Habitat.-Common, especially inshore, off Musselburgh and in the upper parts of the estuary. (See Norman, op. cit., for a list of synonyms.)

23. Macromysis inermis (Rathke).

1843. Mysis inermis, Rathke, Beitr. zur Fauna Norw., p. 20.

Habitat.-Off Bo'ness in November 1887, and in February

${ }^{1}$ Cf. Stebbing on the name of the genus in A History of Crustacea, p. 267 (1893). 
1895. I have also observed it at Stations V., VIII., and IX., though somewhat sparingly.

Genus (14) Schistomysis, Norman, 1892.

24. Schistomysis spiritus, Norman.

1860. Mysis spiritus, Norman, Ann. and Mag. Nat. Hist. (3), vol. vi. p. 431, pl. viii. fig. 1 ,

Habitat.-Off Bo'ness in November 1887, and subsequently at nearly all the Experimental Stations. Moderately frequent.

25. Schistomysis ornata (G. O. Sars).

1864. Mysis ornata, G. O. Sars, Zool. Reise 1863, i Chr. Stifter, p. 18.

Habitat.-Off Bo'ness in November 1887, with the others recorded above, and at nearly all the Experimental Stations.

Genus (15) Neomysis, Czerniavsky, 1882.

26. Neomysis vulgaris (J. V. Thompson).

1828. Mysis vulgaris, J. V. Thompson, Zoolog. Researches, vol, i. p. 30 .

Habitat.-Moderately common in some parts of the estuary, as west of Queensferry and off Musselburgh. I have also captured it in Granton Harbour. In shoals at the mouth of Belhaven Burn, September 1905 (Evans).

\section{Order 2. EDRIOPHTHALMA. \\ Suborder Sympoda. ${ }^{1}$}

In the preparation of this part of the Catalogue, I have adhered more or less closely to the arrangement and nomenclature of Sars Crustaced of Norway, vol. iii., published 18991900. See also a paper by myself in the Annals of Scottish Natural History for October 1900.

1 See remarks on this group by Rev. T. R. R. Stebbing, in his account of the Crustacea brought by Dr Whlley from the South Seas, published by the Cambridge University Press, December 1900. 


\section{Family B O D OTRIID}

\section{Genus (1) Bodotria, Goodsir, 1843.}

1. Bodotria arenosa, Goodsir.

1843. Bodotria arenosa, Goodsir, Edin. New Phil. Jour., vol. xxxiv. p. 120, pl. iii. (See also Proc. Roy. Phys. Soc., vol. ii. p. 10.)

Habitat.-Firth of Forth, 1841-42 (Goodsir).

2. Bodotria scorpioides (Montagu).

1808. Cancer scorpioides, Mont., Trans. Linn. Soc., vol. ix. p. 70, pl. vi. fig. 5.

1843. Cuma Edwardsii, Goodsir, op. cit., p. 123, pl. ii. figs. 1-13.

Habitat.-Firth of Forth (Goodsir). Largo Bay (Leslie and Herdman). Dredged off Musselburgh and a few other places.

3. Bodotria pulchella (G. O. Sars).

1879. Cuma pulchella, G. O. Sars, Middlehavets Invertebratfauna (II. Cumaceer), p. 24, pl. vi.

Habitat.-Off St Monans, Largo Bay, and in the neighbourhood of Fidra; moderately common.

Genus (2) Cumopsis, G. O. Sars, 1879.

\section{Cumopsis Edwardsii (Spence Bate).}

1856. Cuma Edwardsii, Bate, Ann. and Mag. Nat. Hist. (2), vol. xvii. p. 457, pl. xiv.

1860. Bodotria Goodsiri, Van Beneden, Rech. sur la faune litt. de Belgique (Crust.), p. 76, pl. xiii.

Habitat.-Taken at Joppa, iu pools between tide-marks, in 1888. Captured with bottom tow-net at Station III., in September 1891, and subsequently in various other parts of the estuary.

\section{Genus (3) Iphinoë, Spence Bate, 1856.}

5. Iphinoё trispinosa (Goodsir).

1843. Cuma trispinosa, Goodsir, Edin. New Phil. Jour., vol. xxxiv. p 126, pl. iii.

1856. Venilia gracilis, Bate, Ann. and Mag. Nat. Hist. (2), vol. xvii. p. 460, pl. xv. fig. 7 ( 8 ).

Habitat.-Firth of Forth (Goodsir). Bass Rock, 24 
fathoms (Metzger). This species is not rare in the Forth estuary, especially inshore, where the bottom consists of muddy sand.

Family V A U N T H O M P S ON I D A.

Genus (4) Vaunthompsonia, Spence Bate, 1858.

6. Vaunthompsonia cristata, Bate.

1858. Vaunthompsonia cristata, Bate, Nat. Hist. Review, vol. v. p. 203.

Habitat.-Off the west side of May Island on 11th March 1896. This appears to be a rare species in the Forth estuary.

Family L A M P R O P I D Æ.

Genus (5) Lamprops, G. O. Sars, 1862.

7. Lamprops fasciata, G. O. Sars.

1862. Lamprops fasciata, G. O. Sars, Zool. Reise i Sömmeren, 1862, p. 44.

Habitat-Near Joppa, frequent between tide-marks; also taken in Granton Harbour. It is not uncommon in shallow inshore water, where the bottom is muddy sand.

\section{Family LEUCONID}

Genus (6) Leucon, Kröyer, 1846.

8. Leucon nasicus, Kröyer.

1841. Cuima nasica, Kröyer, Naturh. Tidsskrift, 1 R., B. iii. p. 524, pl. vi. figs. 31-33.

Habitat.-More or less frequent all over the estuary; its distribution appears to be somewhat irregular, due in part, perhaps, to seasonal variation. My latest record of the species is for Station V., where it was captured on 26th April 1901.

Genus (7) Eudorella, Spence Bate, 1867.

9. Eudorella emarginata (Kröyer).

1846. Leucon emarginatus, Kröyer, Naturh. Tidssk. Ny R., B. ii. pp. 181 and 209, pl. ii. fig. 3, $a-h$.

Habitat.-Taken in deep water near the seaward limits of the estuary; not common. 


\section{Eudorella truncatula, Spence Bate.}

1856. Eudora truncatula, Bate, Ann. and Mag. Nat. Hist. (2), vol. xvii. p. 457 , pl. xiv. fig. 3.

1900. Eudorella truncatula, G. O. Sars, op, cit., p. xxxvii, pl. xxix.

Habitat.-Firth of Forth, sparingly distributed; my latest record is for Station III., where it was collected on 23rd May 1901. Immature specimens are not uncommon, but adults of either sex are rare.

Genus (8) Eudorellopsis, G. O. Sars, 1882.

11. Eudorellopsis deformis (Kröyer).

1846. Leucon deformis, Kröyer, op. cit., p. 194, pl. ii. fig. 4.

Habitat.-Taken off St Monans and in Aberlady Bay, 1890 ; not common. This species, though somewhat rare, is widely distributed.

Family D I A T Y L I D

Genus (9) Diastylis, Say, 1818.

\section{Diastylis Rathkei (Kröyer).}

1841. Cuma Rathkei, Kröyer, Naturh. Tidssk., vol. iii. p. 513, pls. v. and vi. figs. 17-30.

Habitat.-Not very rare in the Firth of Forth. A considerable number of specimens were captured by the dredge off the west side of Inchkeith in 1888: both females and adult males were present in this gathering. Prof. G. O. Sars mentions (Crustacea of Norway, p. 108) that the drawings of the male on plate lxxii. of his fine work on this group were prepared from a Forth specimen. Adam White, in his Popular History of British Crustacea, considered the Alauna rostrata of Goodsir to be synonymous with $D$. Rathkei (Kröyer),-an opinion which is also shared by Canon Norman.

13. Diastylis rugosa, G. O. Sars.

1864. Diastylis rugosa, G. O. Sars, Chr. Vid.-Selsk. Forhandl. (1864), p. 41.

Habitat.-Generally distributed, but not common. It has been taken in Largo Bay, off St Monans, off North Berwick, and in the deep water west of May Island. 
14. Diastylis lucifera (Kröyer).

1841. Cuma lucifera, Kröyer, Naturh. Tidsskx., 1 R., B. iii. p. 527.

Habitat.-It has been taken very sparingly off the west side of Inchkeith, and at Stations V. and VII.; not common.

15. Diastylis rostratus (Goodsir).

1843. Alauna rostrata, Goodsir, Edin. New Phil. Jour., vol. xхxiv. p. 130, pl. iv. figs. 1-10. (See also Proc. Roy. Phys. Soc., vol. ii. p. 10.)

1869. Diastylis loevis, Norman, ${ }^{1}$ Brit. Assoc. Rept. (1868), p. 27.

1900. ," rostratus, G. O. Sars, Crustacea of Norway, p. 51, pl. 39.

Habitat.-Firth of Forth (Goodsir). Off Fidra, in 12 fathoms (Henderson). I have obtained Diastylis lavis, Norman, at Experimental Stations III., V., VI., and VII., but always very sparingly.

\section{Diastylis spinosa, Norman.}

1869. Diastylis spinosa, Norman, Brit. Assoc. Rept. for 1868, p. 271.

Habitat.-Off North Berwick, in 10 to 15 fathoms; captured in March 1891, but not identified till 1900. The species was described from specimens taken by Norman in Shetland in 1863. It was subsequently discovered in the Moray Firth by Thomas Edward of Banff, and in the Firth of Clyde by Dr Robertson of Millport, Cumbrae.

\section{Family P S E U D O C U M I D E.}

Genus (10) Pseudocuma, G. O. Sars, 1864.

17. Pseudocuma cercaria (Van Beneden).

1861. Leucon cercaria, Van Beneden, Rech. sur la Faune litt. de Belgique (Crust.), p. 85, pl. iv.

Habitat.-Common, and generally distributed in the Firth.

18. Pseudocuma similis, G. O. Sars.

1900. Pseudocuma similis, G. O. Sars, Crustacea of Norway, vol. iii. p. 76, pl. liii.

Habitat.-Firth of Forth, apparently rare, but it resembles

${ }^{1}$ Canon Norman considers that the Alauna rostrata of Goodsir is not the same as his Diastylis loevis, but is rather synonymous with Kröyer's $D$. Rathkei as stated above. If that is so, D. loevis will have to be restored for this species.

VOL. XVI. 
the common Pseudocuma cercaria so closely that it is easily overlooked. The specimens I have were dredged at Station V., on 24 th April 1901.

Genus (11) Petalosarsia, Stebbing, 1893.

19. Petalosarsia declivis (G. O. Sars).

1864. Petalopus declivis, G. O. Sars, Chr. Vid. Selsk. Forhandl. (1864), p. 72 .

Habitat.-Dredged in Largo Bay in March 1891; in the neighbourhood of May Island on 14th April 1893, and very sparingly in other parts of the estuary.

Family N A N N A S T A C I D E.

Genus (12) Cumella, G. O. Sars, 1864.

20. Cumella pygmcea, G. O. Sars.

1864. Cumella pygmaea, G. O. Sars, Chr. Vid. Selsk. Forhandl. (1864), p. 74.

1869. „, agilis, Norman, Brit. Assoc. Rept. (1868), p. 272.

Habitat.-Taken at Station VI. (off St Monans), in May and again in July 1901 ; rare. This is a minute species, and easily missed; it may therefore be more frequent in the Forth estuary than at present it appears to be.

Family CA M P Y L A S P I D Æ.

Genus (13) Campylaspis, G. O. Sars, 1864.

21. Campylaspis rubicunda (Lilljeborg).

1855. Cuma rubicunda, Lillj., Öfvers af Vet.-Akad, Forhandl., p. 121.

Habitat.-Taken in the neighbourhood of the Bass Rock in 1889, and at Station V. on 30th August 1894. It has also been taken off the east side of May Island, but always very sparingly. This appears to be a deep-water species, and is usually found on a muddy bottom.

\section{Suborder Isopoda.}

The work I have followed in the arrangement and nomenclature of the Isopoda is Prof. G. O. Sars' Crustrcea of Norway, vol. ii. (1896-1899). 
The Rev. Canon Norman's papers on "British Land Isopoda" and "British Isopoda Chelifera" [in Ann. and Mag. Nat. Hist. (7), vol. iii. (January and April 1899)] have been useful to me in the preparation of this section of the Catalogue, and to shorten the synonymy the reader is referred to these works; also to a paper by myself in the Annals of Scottish Natural History for October 1898.

\section{Chelifera.}

Family TANA I D .

Genus (1) Tanais, M.-Edwards, 1828.

1. Tanais Cavolinii, H. Milne-Edwards.

1828. Tanais Cavolinii, M.-Edw. in Préces d'Entom., by Audouin, and M.-Edw., vol. i., pl. xxix. fig. 1.

1842. ", tomentosus, Kröyer, Naturh. Tidsskr., R. 1, vol. iv. (1842-43), p. 167.

Habitat.-Taken at May Island and Dunbar, about half tide, living chiefly among mussels (Henderson).

Genus (2) Paratanais, Dana, 1852.

2. Paratanais Batei, G. O. Sars.

1866. Paratanais forcipatus, Bate and Westw., Brit. Sessile-eyed Crust., vol. ii. p. 138.

Habitat.—Off North Berwick, December 1892; dredged off North Craig, near Inchkeith, in 10 to 12 fathoms on 4th July 1901, apparently rare.

Genus (3) Typhlotanais, G. O. Sars, 1880.

3. Typhlotanais brevicornis, Lilljeborg.

1865. Tanais brevicornis, Lillj., Bidrag til Känned. Sver. och Norr. Crust. af Isopod. und.-ord. och Tanaidernes fam., p. 15.

Habitat.-Firth of Forth, 1894; rare. This specimen, though collected in 1894, has only recently been identified.

Genus (4) Leptognathia, G. O. Sars, 1880.

4. Leptognathia brevimana (Lilljeborg).

1865. Tanais brevimana, Lillj., op. cit., p. 22.

Habitat.-Taken in 1891 and 1892. Station VII., in 17 
fathoms, 9th July 1901. This, like the species already recorded, was obtained in the deeper parts of the estuary.

5. Leptognathia breviremes (Lilljeborg). 1865. Tanais breviremis, Lillj., op. cit., p. 21.

Habitat.-Firth of Forth, 1891 and 1892; moderately rare.

6. Leptognathia Lilljeborgia, Stebbing.

1891. Leptognathia Lilljeborgia, Stebbing, Ann. and Mag. Nat. Hist. (6), vol, viii. p. 328, pl. 16.

Habitat._Largo Bay, and off Musselburgh, in 1891. Off North Berwick in December 1892. Off Aberdour, November 1893 ; apparently rare.

\section{Leptognathia longiremis (Lilljeborg), var.}

1865. Tanais longiremis, Lilljeb., op. cit., p. 19.

1901. Leptognathia longiremis, var., T. Scott, Nineteenth F. B. Rept., pt. iii. p. 269, pl. xviii. figs. 30-38.

Habitat.-Off North Berwick, December 1892 and January 1894. Off Musselburgh, 30th May 1891, and in the neighbourhood of the Bass Rock on 9th July 1901. This form, as shown by the drawings in the Fishery Board Report referred to, differs from the typical $L$. longiremis by the apparent absence of the lateral denticles on the terminal segment of the metasome, and, moreover, the antennules in the female are sometimes composed of five instead of four joints. Perhaps variety varia might be a suitable name for this form. ${ }^{1}$

Genus (5) Tanaopsis, G. O. Sars, 1896.

8. Tanaopsis laticaudata, G. O. Sars.

1881. Leptognathia laticaudata, G. O. Sars, Archiv f. Math. og Naturvid., p. 43.

Habitat.-Firth of Forth, 1891. Dredged at Station III. on 23rd May, and at Station VII., in 17 fathoms, on 9th July 1901.

${ }^{1}$ As there are no specimens in my collection of the Leptognathia rigida, Spence Bate, mentioned in my Notes on some Scottish Marine Isopods, I am unable to verify the record, and prefer, therefore, to exclude it from the present Catalogue. 


\section{FLABELLifera.}

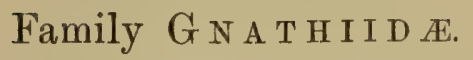

Genus (6) Gnathia, Leach, 1814.

9. Gnathia maxillaris (Montagu).

1804. Oniscus maxillaris, Mont., Trans. Linn. Soc., vol. vii. p. 65, pl. vi. fig. 2.

1814. Gnathia termitoides, Leach, Edin. Encyclop., vol. vii. p. 402.

1818. Anceus maxillaris, Lamarck, Animaux Sans Vertèbres, vol. v. p. 168.

Habitat.-Near Inchkeith, 1888, and subsequently in various parts of the estuary; the female being more frequently met with than the male.

\section{Family C I R O L A N I D 㤅.}

\section{Genus (7) Eurydice, Leach, 1815.}

10. Eurydice pulchra, Leach.

1815. Eurydice pulchra, Leach, Trans. Linn. Soc., vol. xi. p. 370. 1867. Bate and Westwood, Brit. Sess.-eyed Crust, vol. ii. p. 310.

Habitat.-Taken off Preston Island, west of Queensferry, 28th November 1887; and at Station III., November 1890. I have not met with this species very frequently in the Forth estuary.

\section{Family LIM N O R I D Æ.}

Genus (8) Limnoria, Leach, 1814.

\section{Limnoria lignorum (Rathke).}

1799. Cymothod lignorum, Rathke, Skrifter af Naturh. Selsk., p. 101, pl. iii. fig. 14.

1814. Limnoria terebrans, Leach, Edin. Encycl., vol. vii. (Crust.) p. 433.

Habitat.-Firth of Forth, at Elie (Leslie and Herdman). Common, burrowing in old wood of piers, wharves, etc., exposed between tide-marks on both sides of the estuary. 
Family S P H \& R O M I A E.

Genus (9) Sphæroma, Latreille, 1802.

12. Sphocroma rugicauda, Leach.

1814. Sphoroma rugicauda, Leach, Edin. Encycl., vol. vii. p. 405. Habitat.-In brackish pools at Aberlady; common.

Genus (10) Næsa, Leach, 1818.

13. Noesa bidentata (Adams).

1798. Oniscus bidentatus, Adams, Trans. Linn. Soc., vol. v. p. 8, pl. ii. figs. 3 and 4.

Habitat.-Found alive amongst barnacles and weed scraped from a ship's hull at Granton Harbour in 1888 (cf. Ann. Scot. Nat. Hist. (April 1899), p. 116).

VALVIFERA.

Family I D O T H E I D

Genus (11) Idothea, Fabricius, 1798.

14. Idothea baltica (Pallas).

1774. Oniscus balticus, Pallas, Spicil Zool., fasc. ix. p. 66, pl. iv. fig. 6, A-D.

1825. Idotea tricuspidata, Desmarest, Consid. sur Crust., p. 289.

Habitat.-Firth of Forth, in shallow water at various places (Leslie and Herdman). Moderately common upon Laminaria and other sea-weeds in shallow water on both sides of the estuary.

15. Idothea pelagica, Leach.

1815. Idothea pelagica, Leach, Trans. Linn. Soc, vol. xi. p. 365. 1868. " " Bate and Westw., Brit. Sessile-eyed Crust., vol. ii. p. 384 .

Habitat.- "Common on the Bell Rock in the Firth of Forth" (Bate and Westwood, op. cit., p. 385). "Bell Rock" is doubtless, I think, a misprint for Bass Rock, for it is described as being "in the Firth of Forth," whereas the Bell Rock is 13 or 14 miles north by east of Fife Ness, the extreme limit of the Forth estuary on the north side. 


\section{Idothea emarginata (Fabricius).}

1794. Cymothoa emarginata, Fabr., Entomon. Syst., vol. ii. p. 508.

Habitat.-Aberlady Bay, 1888. Station I., 23rd May 1891. Occasionally obtained with I. baltica amongst Laminaria at various places within the estuary.

\section{Idothea linearis (Linné).}

1767. Oniscus linearis, Linn., Syst. Nat., vol. ii. p. 1060.

1868. Idotea linearis, Bate and Westw., op. cit., vol, ii. p. 388.

Habitat.-Occasionally at Newhaven (Henderson). Off Crail, 1888. Station X. (west of Queensferry), 31st August 1894, and 26th April 1901. Station IV., 22nd April 1901. Several of the specimens are adorned with longitudinal light and dark lines (cf. form $I$. sexlineata, Kröyer).

\section{Family A R C T UR ID $\mathbb{E}^{1}{ }^{1}$}

Genus (12) Astacilla, Cordiner, 1795.

18. Astacilla longicornis (Sowerby).

1806. Oniscus longicormis, Sow., British Miscellany, Taf. $19^{2}$

1841. Leachia gracilis, Goodsir, Edin. New Phil. Jour., vol. xxxi. p. 310 , pl. vi. fig. 4 ( $\delta$ ).

1868. Arcturus longicornis, Bate and Westw., Brit. Sessile eyed Crust., vol. ii. p. 365 .

Habitat.-Firth of Forth (Goodsir). Off Dysart, T. W. Simmons (cf. Bate and Westwood, op. cit., vol. ii. p. 369). Moderately frequent in the estuary, and generally distributed. G. O. Sars considers the $A$. gracilis of Goodsil to be the male of $A$. longicornis.

19. Astacilla intermedia (Goodsir). 1841. Leachia intermedia, Goodsir, op. cit., p. 309, pl. vi. fig. 1. 1868. Arcturus intermedius, Bate and Westw., Brit. Sessile-eyed Crust., p 371.

Habitat.-Taken off Anstruther (Goodsir). This is the

${ }^{1}$ As Astacilla, Cordiner, was instituted in 1795, and Arcturus, Latrille, in 1804, the family name should perhaps be AsTACILLID e, from the older genus.

"James Sowerby, "British Miscellany; or, Colsured Figures of New, Rare, or Little-Known Animal Subjects, many not befure ascertained to be Natives of the British Isles." London, 1806, 8vo. 
Astacilla affinis, G. O. Sars (Crustacea of Norway, vol. ii. p. 90).

Genus (13) Arcturella, G. O. Sars, 1897.

20. Arcturella dilatata, G. O. Sars.

1882. Astacilla dilatata, G. O. Sars, Overs. af Norges Crust., vol. i. p. 63 , pl. ii. fig. 3.

Habitat.-Dredged off St Monans, 22nd May 1901; only a single male specimen was obtained.

\section{Asellota.}

Family A SELID

Genus (14) Asellus, G. St Hillaire, 1764.

21. Asellus aquaticus (Linné).

1761. Oniscus aquaticus, Linn., Fauna Suecica, 2nd ed., p. 500.

1868. Asellus aquaticus, Bate and Westw., Brit. Sessile-eyed Crust., vol, ii. p. 343.

Habitat.-Pond at Redbraes, near Edinburgh, "in remarkable profusion" (Sir J. Dalyell). Very common in Union Canal, near Gilmore Place, Edinburgh (1889-90); Duddingston Loch (1897). Marchfield Pond, very common (Dr and Miss Sprague, July 1900). Braid Burn; Peffer Burn, near Aberlady, etc. (W. Evans). Upper Elf Loch, Braid Hills, common in 1905 (W. Evans).

- Family J'A N I R I D

Genus (15) Janira, Leach, 1813

22. Janira maculosa, Leach.

1813. Janira maculosa, Leach, Edin. Encycl., vol. vii. p. 434.

Habitat.-Firth of Forth, off Bo'ness, 1887. Taken at Station IX. in April 1870, and subsequently at other stations, but always very sparingly.

Genus (16) Jæra, Leach, 1813.

23. Jara marina (O. Fabricius).

1780. Oniscus marinus, Fabr., Fauna Grönlandica, p. 252.

1813. Joera albifrons, Leach, Edin. Encycl., vol. vii. p. 434.

Habitat.-Common at May Island and Granton Quarry 
under stones, near high-water mark (Henderson). Dredged off Inchkeith; taken between tide-marks at Joppa and other places; frequent. South Queensferry (Evans). Sars is somewhat doubtful whether the form figured by Bate and Westwood under the name of Joera Nordmanni, Rathke, is the true Rathkian species, or more probably the male of Joera marina.

Family M U N N D

Genus (17) Munna, Boeck, 1839.

24. Munna Kröyeri, Goodsir.

1842. Munna Kröyeri, Goodsir, Edin. New Phil. Jour., vol. xxxiii. p. 365 , pl. vi. fig. 6 .

Habitat.-Firth of Forth (Goodsir). Off the west side of Inchkeith (1887). Dredged at Station III., and at the northwest end of Inchkeith, in May 1901; not very common.

Genus (18) Paramunna, G. O. Sars, 1866.

25. Paramunna bilobata, G. O. Sars.

1866. Paramunna bilobata, G. O. Sars, Beretning om en i Somm., 1865, foretag. Zool. Reise ved Kyst. af Christiania og Christiansands Stift., p. 31.

Habitat.-Firth of Forth, 1894. Moderately rare in dredged material from Stations VI. and III., and from the north-west end of Inchkeith, collected by F. G. Pearcey in May 1901.

Genus (19) Pleurogonium, G. O. Sars, $1871 .^{1}$

26. Pleurogonium rubicundum, G. O. Sar's.

1863. Pleuracantha rubicunda, G. O. Sars, Chr. Vidensk. Selsk. Forhandl., p. 16.

Habitat.-Firth of Forth, 1894 and 1895; rare.

1 The Rev. Canon Norman, in a paper entitled "A Month on the Trondbjem Fiord" (Ann. and Mag. Nat. Hist. (6), vol. xiii. p. 281), remarks, "The genus Leptaspidia, Bate and Westwood, is, I think, unquestionably a synonym of Pleurogonium." Moreover, it seems to me that Bate and Westwood's text-figure of Leptospidia resembles Pleurogonium inermie more closely than any other species of the genus. 
27. Pleurogonium inerme, G. O. Sars.

1882. Pleurogonium inerme, G. O. Sars, Oversigt af Norges Crust., vol. i. p. 67 , pl. ii. fig. 5 .

1891. Leptaspidia brevipes, T. Scott, Ninth F. B. Rept., pt. iii. p. 308. Habitat.-Taken off Musselburgh, April 1891.

28. Pleurogonium spinosissimum, G. O. Sars.

1866. Pleuracantha spinosissima, G. O. Sars, Beretning om en i Somm., 1865, foretag. Zool. Reise ved, Kyst. af Christiania og Christiansands Stift., p. 30.

Habitat.-Taken at the north-west end of Inchkeith, 23rd May 1901 ; rare.

Genus (20) Eurycope, G. O. Sars, 1863.

29. (?) Eurycope mutica, G. O. Sars.

1863. Eurycope mutica, G. O. Sars, Chr. Vid. Selsk.-Forhandl. (1863), p. 6.

Habitat.-Firth of Forth, near the Bass Rock, in 20 fathoms, 28th June 1904; two specimens that appear to belong to this species-one of them an ovigerous femalewere obtained.

\section{ONISCOIDA.}

"This tribe comprises the air-breathing or terrestrial Isopoda" (G. O. Sars).

Family L I G I I D Æ.

Genus (21) Ligia, Fabricius, 1798.

30. Ligia oceanica (Linné).

1767. Oniscus oceanicus, Linn., Syst. Nat., ed. xii., vol. ii. p. 1061.

Habitat.-Cramond, 1888 (Mihi). Aberlady, November 1891; North Berwick, August 1897; and shore at Dalmeny, March 1901 (W. Evans). Also at Granton and other places, under stones on the shore. 


\section{Family T R I C H O N I S I D}

Genus (22) Trichoniscus, Brandt, 1833.

\section{Trichoniscus pusillus, Brandt.}

1833. Trichoniscus pusillus, Brandt, Conspect. Monogr. Crust. Oniscodorum, p. 12, pl. iv. fig. 9 .

1891. Philougria riparia, T. Scott., Proc. Roy. Phys. Soc. Edin., vol. xi. p. 76 .

Habitat.--Under stones at St Margaret's Hope, Cramond Island, Arthur's Seat, Largo, and other places; moderately frequent. Generally distributed (W. Evans).

\section{Trichoniscus roseus (C. L. Koch).}

1838. Itea rosea, Koch, Deutschlands Crustaceen, p. 22, fig. 16.

1887. Philougria rosea, T. Scott, Trans. Nat. Hist. Soc. Glasg., vol. i. (N.S.) p. 373.

Habitat.-Under stones at South Queensferry, 23rd March 1901 (W. Evans, in Ann. Scot. Nat. Hist., April 1901); in garden, Morningside, September 1905 (Evans). Salisbury Crags, Edinburgh, July 1887; and Cramond Island, 18th April 1888. These last two records were overlooked in the preparation of my paper on "The Land and Fresh-Water Crustacea of the District around Edinburgh," part i., published in Proc. Roy. Phys. Soc. Edin., vol, xi. p. 73 et seq.

\section{Family O N I S C I D Æ.}

\section{Genus (23) Oniscus, Linné, 1761.}

33. Oniscus asellus, Linné.

1761. Oniscus asellus, Linn., Fauna Suecica, vol. iv. p. 183, No. 2058 ; and Syst. Nat., ed. xii., vol. ii. p. 1061.

Habitat.-Common everywhere, usually hiding under stones, old wood, etc. O. fossor, Bate and Westw., is now regarded as a form of $O$. asellus.

${ }^{1}$ On the occasion of this visit to Cramond Island in April 1888, a friend and I crossed over to it about 1 A.M. - just before the track was covered by the rising tide-aud we remained on the island till the tide ebbed and began to flow again. The interval from the time that daylight made things visible till we recrossed to the mainland, was spent in searching for natural history objects, and especially for the smaller Crustacea, and with fairly satisfactory results. 
Genus (24) Philoscia, Latreille, 1804.

34. Philoscia muscorum (Scopoli).

1763. Oniscus muscorum, Scopoli, Entomologia Carniolica, p. 415.

Habitat.-Under stones, among dead leaves, ete; common, and generally distributed.

Genus (25) Platyarthrus, Brandt, 1833.

35. Platyarthrus Hoffmannseggi, Brandt.

1833. Platyarthrus Hoffmannseggi, Brandt, Consp. Monogr. Crust. Onisc., p. 12, pl. iv. fig. 10.

1900, W. Evans, Ann. Scot. Nat. Hist. (July 1900), p. 186.

Habitat.-Near Inverkeithing, Fifeshire, "in nests of the common ashy-black ant, Formica fusca" (W. Evans, Edinburgh). The only other Scottish record for this curious species is that by Thomas Edward, of Banff, in the list of Crustacea in Smiles' Life of Edward.

Genus (26) Porcellio, Latreille, 1804.

36. Porcellio scaber, Latreille.

1804. Porcellio scaber, Latr., Hist. Nat. Générale et particulière des Crust. et des Insectes, vol. vii. p. 45.

Habitat.-Under stones, old wood, etc., everywhere.

37. Porcellio pictus, Brandt.

1830. Porcellio pictus, Brandt and Ratzeburg, Medicin. zoologie, vol. ii. p. 78, pl. xii. fig. 5.

1891. ", ", T. Scott, Proc. Roy. Phys. Soc. Edin., vol. xi. p. 78.

Habitat. - At the foot of a wall near Seafield, Leith, April 1888; apparently rare. Taken under a stone near Dunbar in 1904 (W. Evans).

Genus (27) Cylisticus, Schnitzler, 1853.

38. Cylisticus convexus (De Geer).

1778. Oniscus convexus, De Geer, Mem. pour Servir a l'hist. des Ins., vol. vii. p. 563, pl. $\mathrm{xxxv}$. fig. 11 .

1891. Porcellio armadilloides, T. Scott, Proc. Roy. Phys. Soc. Edin., vol. xi. p. 79.

Habitat.-Under stones at the foot of Salisbury Crags, 
14th April 1888, and subsequently; not common. Foot of Salisbury Crags (W. Evans).

Family A R M A ILLIDIID

Genus (28) Armadillidium, Brandt, 1830.

39. Armadillidium vulgare (Latreille). 1804. Armadillo vulgaris, Latr., Hist. Nat. Crust. et Insectes, vol. vii. p. 48.

1891. ", " T. Scott, Proc. Roy. Phys. Soc. Edin., vol. xi. p. 79.

Habitat.-Under stones at Salisbury Crags. Salisbury Crags, Blackford Hill, Pettycur, St David's (Fife), etc. (W. Evans).

\section{EPICARIDA.}

The Epicarida are but poorly represented in this "Catalogue of Forth Crustacea," and further careful research should add considerably to this group.

\section{Family B O P Y R I E.}

Genus (29) Athelges, Hesse, 1861.

40. Athelges paguri (Rathke).

1843. Phryxus paguri, Rathke, Nova Acta Acad. Nat. Curios., vol. xx. p. 57, pl. i. figs. 13-15; pl. ii. figs. 11 and 12.

Habitat.-Firth of Forth, parasitic on Eupagurus bernhardus (Dr J. Anderson).

Genus (30) Phryxus, Rathke, 1843.

41. Phryxus abdominalis (Kröyer).

1840. Bopyrus abdominalis, Kröyer, Nat. Tidsskr., vol. iii. p. 102, pls. i. and ii.

Habitat.-Firth of Forth, off St Abb's Head, 40 fathoms (Metzger). Station III., parasitic on Pandalus Montagui, Leach, 9th May 1901. 
Family CR Y P T O I S C I $Æ$.

Genus (31) Cryptothir, Dana, 1852.

42. Cryptothir balani, Spence Bate.

1860. Liriope balani, Bate, Brit. Assoc. Rept. (1860), p. 225.

1869. Cryptothiria balani, Bate and Westw., Brit. Sessile-eyed Crust, , vol. ii. p. 267 .

Habitat.-Firth of Forth, parasitic on Balanus balanoides (inside the shell). This is one of the interesting additions to the fauna of the Firth of Forth by H. D. S. Goodsir. I obtained a single specimen of this curious parasite at East Tarbert, Loch Fyne, on the same kind of barnacle.

\section{Suborder Amphipoda.}

The classification (and arrangement) generally followed is that of G. O. Sars' Crustacea of Norway, vol. i. (Amphipoda), 1890-95. See also papers on "British Amphipoda," by Rev. A. M. Norman, in Ann. and Mag. Nat. Hist. for January, February, April, and July 1900.

\section{HYPERIIDEA.}

Family HYPERIID E.

Genus (1) Hyperia, Latreille, 1825.

1. Hyperia galba (Montagu).

1815. Cancer gammarus galba, Mont., Trans. Linn. Soc., vol, xi. p. 4 , pl. ii. fig. 2.

Habitat.-Frequent and generally distributed; often found associated with Aurelia cyanea and other large Medusæ.

Genus (2) Hyperoche, Bovalius, 1887.

2. Hyperoche tauriformis (Pate and Westwood).

1868. Hyperia tauriformis, Bate and Westw., Brit. Sessile-eyed Crustacea, vol. ii. p. 519.

1890. Hyperoche Kröyeri, G. O. Sars, Crustacea of Norway, vol. i. p. 9, pl. iv.

Habitat.-Generally, though sparingly, distributed throughout the estuary. 
Genus (3) Parathemisto, Boeck, 1870.

3. Parathemisto oblivia (Kröyer).

1838. Hyperia oblivia, Kröyer, Gronlands Amphipoder, p. 70, pl. iv. fig. 19.

Habitat.-Generally distributed, usually more or less frequent, and at times abundant, especially in the seaward part of the estuary, and particularly in winter and spring.

Genus (4) Euthemisto, Bovalius, 1887.

4. Euthemisto compressa (Grës).

1865. Themisto compressa, Goës, Öfvers $\mathrm{k} \cdot$ Vet.-Akad. Forhandl., p. 533 , pl. xli. fig. 34 .

Habitat.-Taken sparingly off the west side of May Island in February 1892 and November 1893 ; and at Station VII. (off North Berwick) in November 1892. These were probably stragglers from the great shoal of Euthemisto reported off the Yorkshire coast in February 1892.1

\section{Gammaridea.}

Family OR C H E S T I I Æ.

Genus (5) Talitrus, Latreille, 1802.

5. Talitrus locusta (Pallas).

1772. Oniscus locusta, Pallas, Spicilegia Zoologica, fasc. 9, pl. iv. fig. 7 .

Habitat.- "Very abundant about high-tide mark among stones, seaweed, etc." (L. and H.). I have taken T. locusta near Dunbar. At high-water mark sandy beaches, Gullane and North Berwick (Evans).

Genus (6) Orchestia, Leach, 181.

6. Orchestia littorea (Montagu).

1804. Cancer gammarus littoreus, Mont., Trans. Linn. Soc., vol. ix. p. 96 , pl. iv. fig. 4 .

Habitat.-Common on the shore west from Granton amongst decaying seaweed at about high-tide mark. Taken also on the shore near Dunbar. Aberdour and Prestonpans (Evans).

${ }^{1}$ Cf. T. H. Nelson in Naturalist for May 1892. 
Genus (7) Hyale, Rathke, 1837.

7. Hyale Nilssoni (Rathke).

1843. Amphitoe Nilssoni, Rathke, Acta Akad. Leopold, vol. xx. p. 264.

Habitat.- "Granton Quarry, common; May Island, near high-water" (Henderson). West of Queensferry, rare.

[8. Hyale (Nicea) Lubbockiana (Spence Bate).

This species is recorded among my notes of Amphipoda dredged off St Monans in 1889, but no specimens are in my collection, and I am unable to verify the record.]

\section{Family L Y S I A A S S I D Æ.}

Genus (8) Acidostoma, Lilljeborg, 1865.

9. Acidostoma obesum (Spence Bate).

1862. Anonyx obesus, Bate, Cat. Amphip. Crust. Brit. Museum, p. 74 , pl. sii. fig. 1 .

Habitat.-Dredged between Fidra and the Bass Rock in 1893, and on 9th July 1901; it has also been dredged off St Monans, but always very sparingly.

Genus (9) Socarnes, Boeck, 1870.

10. Socarnes Vahli (Kröyer).

1838. Lysianssa vahlii, Kröyer, Grönlands Amfipoder, p. 5.

1896. Socarnes Vahli, T. Scott, Fourteenth F. B. Rept., part iii. p. 158.

Habitat.-Firth of Forth; very rare.

Genus (10) Calisoma, A. Costa.

11. Calisoma Hopei, A. Costa.

1851. Calisoma Hopei, A. Costa, Hope Cat. Crost. Ital., p. 44, and plate, fig. 2.

1863. " crenata, Bate and Westw., Brit. Sessile-eyed Crust., vol. i. p. 120.

Habitat.-Moderately common in the Firth of Forth; it occurs sometimes in abundance inside the dead tests of Amphidotus and Spatangus, feeding on the decaying animal matter; also on dead fishes. 
Genus (11) Hippomedon, Boeck, 1870.

12. Hippomedon denticulatus (Spence Bate).

1862. Anonyx denticulatus, Bate, Cat. Amphip. Crust. Brit. Mus, p. 75 , pl. xii. fig. 4 .

Habitat.-Taken in the vicinity of May Island in 1888, and subsequently in various parts of the estuary between May Island and Inchkeith, but seldom more than a few specimens taken in any single gathering.

Genus (12) Orchomene, Boeck, 1870.

\section{Orchomene humilis (A. Costa).}

1857. Lysianassa humilis, A. Costa, Mem. del Accad. del Sc. de Napoli, vol. i. p. 187, pl. i. fig. 6 .

1863. Anonyx Edwardsi, Bate and Westw., Brit. Sessile-eyed Crust., vol. i. p. 94.

1890. Orchomene Batei, G. O. Sars, Crustacea of Norway, vol. i. p. 6 , pl. xxii.

Habitat.-In the neighbourhood of the Bass Rock; rare.

\section{Genus (13) Tryphosa, Boeck, 1870.}

\section{Tryphosa nana (Kröyer).}

1846. Anonyx nanus, Kröyer, Naturh. Tidsskr., 2 R., Bd. ii. p. 30.

1891. Orchomenella ciliata, G. O. Sars, op. cit., p. 69, pl. xxv. fig. 2.

Habitat.-Taken near Joppa in 1888; subsequently in other parts of the estuary, but always sparingly.

Genus (14.) Tryphosella, J. Bonnier, 1893.

15. Tryphosella Sarsi, Bonnier.

1891. Tryphosa nana, G. O. Sars, op. cit., p. 76, pl. xxvii. fig. 1.

1893. Tryphosella Sarsi, Bonnier, Bull. Sci. France et Belgique, vol. xxiv. p. 170 (footnote).

Habitat.-Firth of Forth; not common.

16. Tryphosella Höringii (Boeck).

1870. Tryphosa Höringii, Boeck, Crust. Amphip. bor. et aret., p. 38.

Habitat.-Firth of Forth, 1896 ; off the east side of Inchkeith, in 5 fathoms, 23rd May 1901; not common. VOL. XVI. 
17. Tryphosella nanoides (Lilljeborg).

1865. Anonyx nanoides, Lillj., On the Lysianassa magellanica, etc., p. 25, pl. iii. figs. 32-34.

1891. Tryphosa nanoides, G. O. Sars, Crustacea of Norway, vol, i. p. 79, pl. xxviii. fig. 2.

1893. Tryphosella nanoides, Bonnier, op. cit., vol. xxiv. p. 171 (footnote).

Habitat.-Off St Monans, captured with a tow-net at a - depth of about 13 fathoms, in November 1904. In this species, the palm of the first gnathopods does not slope away from the base of the claw (dactylus), but forms nearly a right angle with the sides of the propodos.

Genus (15) Tryphosites, G. O. Sars, 1891.

18. Tryphosites longipes (Spence Bate).

1863. Anonyx longipes and ampula, Bate and Westw., Brit. Sessileeyed Crust., vol. i. pp. 113, 116.

Habitat._-Off St Monans, several specimens, 1889; and subsequently, but sparingly, in other parts of the estuary.

\section{Genus (16) Anonyx, Kröyer, 1838.}

19. Anonyx nugax (Phipps).

1774. Cancer nugax, Phipps, Voyage towards the North Pole, p. 192, pl, xii. fig. 2.

1893. Anопyx nugax, T. Scott, Eleventh F. B. Rept., pt. iii.p. 212, pl. v. ifgs. 18-21.

Habitat.-Near May Island, February 1889. North end of Inchkeith, 23rd January 1896 ; rare.

Genus (17) Hoplonyx, G. O. Sars, 1891.

20. Hoplonyx leucophthalma, G. O. Sars.

1891. Hoplonyx leucophthalma, G. O. Sars, op. cit., p. 97, pl. xxxiv. fig. 1.

Habitat.-This somewhat critical species was taken off St Monans with a tow-net, close to the bottom, in November 1904. In this species the eyes are of a light cream colour or almost white; the dactylus of the first gnathopods has also a row of very minute spines extending along its dorsal aspect 
a little below the upper margin, which appears to be a character peculiar to this species.

Genus (18) Lepidepecreum, Spence Bate, 1868.

21. Lepidepecreum longicorne (Bate).

1861. Anonyx longicornis, Bate and Westw., op. cit., vol. i. p. 91 ( o ).

Habitat.-Off St Monans; off the north end of Inchkeith, January 1896; and off the east side of the same island, May 1901.

\section{Family PON TOPOREIID 死.}

Genus (19) Bathyporeia, Lindström, 1855.

22. Bathyporeia Guilliamsoniana (Bate).

1856. Thersites Guilliamsoniana, Bate, Brit. Assoc. Rept. (1856), p. 59 ; and Ann. Nat. Hist. (2), vol. xix. (1857) p. 146.

1891. Bathyporeia norvegica, G. O. Sars, Crust. of Norway, vol. i. p. 128, pl. xliii.

Habitat.-Firth of Forth; taken sparingly in various parts of the estuary.

23. Bathyporeia pelagica, Spence Bate.

1862. Bathyporeia pelagica, Bate, Cat. Amphip. Brit. Museum, p. 174 , pl. xxxi. fig. 6 .

Habitat.-Firth of Forth; taken occasionally with the other species of the genus.

\section{Bathyporcia Robertsoni, Spence Bate.}

1892. Bathyporeia Robertsoni, Bate, op. cit., p. 173, pl. xxxi. fig. 5.

Habitat.-Firth of Forth, frequent near low-water on the sandy shore east of Burntisland; obtained by passing the wet sand through a wire-sieve.

\section{Genus (20) Haustorius, Statius Müller, 1775.}

25. Haustorius arenarius (Slabber).

1769. Oniscus arenarius, Slabber, Naturkund. Verlustig., etc., p. 92, pl. 11, figs. 3,4 .

Habitat.-Firth of Forth, sandy shore east of Burntisland, near low-water; not common. 
Genus (21) Urothoë, Dana, 1852.

26. Urothoë marinus, Spence Bate.

1862. Urothoë marinus, Bate and Westw., Brit. Sessile-eyed Crust., vol. i. p. 195.

Habitat.-Firth of Forth; not very common.

27. Urothoë brevicornis, Spence Bate.

1862. Urothoë brevicornis, Bate and Westw., op. cit., vol. i. p. 198.

Habitat.-Largo Bay; not common.

Family PHOX OCEPHALID E.

Genus (22) Phoxocephalus, Stebbing, 1888.

28. Phoxocephalus Holbölli (Kröyer).

1842. Phoxus Holbölli, Kröyer, Naturh. Tidsskr., 1 R. p. 157.

Habitat.-Taken off the west side of May Island in 1888. Taken in Largo Bay in 1892 and 1894, and at Station III. on 23rd May 1901.

29. Phoxocephalus Fultoni, T. Scott.

1890. Phoxocephalus Fultoni, T. Scott, Eighth F. B. Rept., pt. iii. p. 327, pl. xii. figs. x.-xii.; pl. xiii. figs. xiii.-xix.

Habitat.-Off St Monans; not rare.

Genus (23) Harpinia, Boeck, 1870.

30. Harpinia neglecta, G. O. Sars.

1891. Harpinia neglecta, G. O. Sars, Crustacea of Norway, vol. i. p. 153 , pl. liii. fig. 1 .

Habitat.-Generally though sparingly distributed. First recorded for the Firth of Forth in 1888. This is the Phoxus plumosus of Bate and Westwood's British Sessile-eyed Crustacea, but not of Kröyer.

31. Harpinia crenulata, Boeck.

'1870. Harpinia crenulata, Boeck, Crust. Amphip. bor. et arctica, p. 56 .

Habitat.--Near Inchkeith, and other parts of the estuary; not common. Station III., in 5 fathoms, 23rd May 1901. 
Family A M P ELISCID Æ.

Genus (24) Ampelisca, Kröyer, 1842.

32. Ampelisca typica (Spence Bate).

1857. Tetromatus typicus, Bate, Ann. and Mag. Nat. Hist. (2), vol. xix. p. 139.

1863. Ampelisca Gaimardi, Bate and Westw., Sessile-eyed Crust., vol. i. p. 127.

Habitat.-Between Fidra and the Bass Rock; not common.

33. Ampelisca tenuicornis, Lilljeborg.

1855. Ampelisca tenuicornis, Lillj., Öfvers af Vet.-Akad. Forhandl., p. 123.

Habitat.-Near the Bass Rock, 24 fathoms; off St Abb's Head, 40 fathoms (Metzger). Off Prestonpans, 1888, not common; off the North Craig, 4th July 1901.

34. Ampelisca assimilis, Boeck.

1870. Ampelisca assimilis, Boeck, Crust. Amphip. borealia et arctica, p. 144.

Habitat.-Taken near May Island, 1893. Off St Monans, in 13 fathoms, and at Station III., in 7 fathoms, May 1901. Several specimens of Ampelisca, including $A$. assimilis, were obtained in the stomachs of Long Rough Dabs captured in the Forth estuary in May 1901.

\section{Ampelisca brevicornis (A. Costa).}

1853. Araneops brevicornis, Costa, Rend. Acc. Napoli, p. 171.

1855. Ampelisca loevigata, Lillj., Öfvers K. Vet.-Akad. Forhandl., 1855 , p. 123.

Habitat.-Largo Bay and one or two other places, 1893. Taken also at Station III., in 7 fathoms, on 23rd May 1901.

36. Ampelisca macrocephala, Lilljeborg.

1852. Ampelisca macrocephala, Lillj., op. cit. (1852), p. 7.

Habitat.-Firth of Forth, 24 fathorns (Metzger). I have obtained this species in the stomachs of Long Rough Dabs and Whitings captured in the Firth of Forth in May 1901, as well as in tow-net gatherings collected about the same time. 
37. Ampelisca spinipes, Boeck.

1870. Ampelisca spinipes, Boeck, Crust. Amphip. borealia et arctica, p. 143.

Habitat.-Taken near May Island, not common, 1893. At Station III., in 5 fathoms, 23rd May 1901. Also in the stomachs of Long Rough Dabs and small Whitings captured in the estuary in May 1901.

38. Ampelisca aquicornis, Bruzelius.

1859. Ampelisca oequicornis, Bruz., K. Vet.-Akad. Handl., vol. iii. p. 82, pl, iv. fig. 15 .

Habitat.-West of May Island, 20 fathoms (Henderson). This appears to be the only record of $A$. oquicornis for the Forth estuary.

Genus (25) Byblis, Boeck, 1870.

39. Byblis Gaimardi (Kröyer).

1848. Ampelisca Gaimardi, Kröyer, Gaimard's Voyaces en Scand., pl. xxiii. fig. 1.

Habitat.-Taken off St Abb's Head, 40 fathoms (Metzger, 1875). Near May Island, 1890 (Mihi).

Genus (26) Haploops, Lilljeborg, 1855.

40. Haploops tubicola, Lilljeborg.

1855. Haploops tubicola, Lillj., Öfvers K. Vet.-Akad. Forhandl. (1855), p. 134.

Habitat.-Taken near the Bass Rock, 1892, and in other parts of the estuary. Dredged in 5 fathoms at Station III., 23rd May 1901; found also in the stomachs of Long Rough Dabs (Drepanopsetta platessoides) captured in the Forth during the same month.

Family A M P H L O C H I D 在.

Genus (27) Amphilochus, Spence Bate, 1862.

41. Amphilochus manudens, Spence Bate.

1862. Amphilochus manudens, Bate, Cat. Amphip. Brit. Mus,, p. 107 , pl. xvii. fig. 6 .

Habitat.-Taken in South Bay in 1888, not common. 
Dredged at Station III., and also at the north-west end of Inchkeith, on 23rd May 1901.

\section{Amphilochus tenuimanus, Boeck.}

1870. Amphilochus tenuimanus, Boeck, Crust. Amphip. borealia et arctica, p. 51:

Habitat.-Taken in the stomach of a small Whiting captured in the estuary in April, and in the stomach of a Long Rough Dab captured in May 1901; obtained also in a small gathering of dredged material at Station IX., collected 5th June 1903.

Genus (28) Amphilochoides, G. O. Sars.

43. Amphilochoides serratipes (Norman).

1869. Probolium serratipes, Norman, Brit. Assoc. Rept. (1868), p. 273.

1892. Amphitochoides odontonyx, G. O. Sars, Crust. of Norw.; vol. i. p. 221, pl. lxxv. fig. 2.

1893.

T. Scott, Eleventh F. B. Rept., pt. iii. p. 215 , pl. v. figs. 41,42 .

Habitat. - Firth of Forth, near Fidra Island; rare. ${ }^{1}$

44. Amphilochoides odontonyx (Boeck).

1870. Amphilochus odontonyx, Boeck, Crust. Amphip. bor. et arct., p. 51.

1896. Amphilochoides odontonyx, T. Scott, Fourteenth F. B. Rept., pt. iii. p. 159, pl. iv. figs. 4-6.

Habitat.-At various places in the Firth of Forth, but always very sparingly. This species was described by Professor G. O. Sars under the name of Amphilochoides pusillus, but was afterwards identified as the true $A$. odontonyx of Boeck; see footnote below.

1 At p. 159 of Part III. of the Fourteenth Annual Report of the Fishery Board for Scotland (1896), in my remarks on Amphilochoides intermedius, I state incidentally that the typical $A$. odontonyx, G. O. Sars ( $A$. serratipes, Norman), had not hitherto been observed in the Firth of Forth; this was a mistake, due to my forgetting that that species had been recorded in Part III. of the Eleventh Annual Report, with drawings showing two of the most characteristic parts of the animal. Further, as pointed out by Professor G. O. Sars (op. cit., p. 690), the form mentioned here is not the $A$. odontonyx of Boeck, but a different species, for which Sars proposed to substitute the name $A$. Boecki, being unaware that Norman had already described it. 
45. Amphilochoides intermedius, T. Scott.

1896. Amphilochoides intermedius, T. Scott, Fourteenth F. B. Rept., pt. iii. p. 159, pl. iv. figs. 1-3.

Habitat.-Taken in various parts of the estuary, but usually very sparingly. The latest records I possess of the occurrence of $A$. intermedius in the Forth are for Station III., where it was obtained on the 23rd and 25th of May 1901.

Genus (29) Gitana, Boeck, 1870.

46. Gitana Sarsi, Boeck.

1870. Gitana Sarsi, Boeck, Crust. Amphip. borealia et arctica, p. 52.

Habitat.-Taken very sparingly in various parts of the estuary. My most recent record of this species is for Station III., where it was dredged on 23rd and 25th May 1901.

47. Gitana abyssicola, G. O. Sars.

1892. Gitana abyssicola, G. O. Sars, Crustacea of Norway, vol. i. p. 229 , pl. lxxviii. fig. 2.

Habitat.-Dredged at Station VI. (off St Monans), 25th May 1901. One of the characters which serves to distinguish this small species from G. Sarsi is that the second pair of coxal plates are rather narrow, and they exhibit only two small serrations on the obtusely-pointed tips of these plates, instead of three, as in G. Sarsi.

Family S T E N O H O I

Genus (30) Stenothoe, Dana, 1852.

48. Stenothoe marina (Spence Bate).

1862. Montagua marina, Bate, Catal. Amphip. Brit. Mus., p. 56, pl. viii. fig. 5.

Habitat.-Various parts in the Firth of Forth from Inchkeith to May Island, but not very common, 1889. Station V., 24th April, and off the north-west end of Inchkeith, 23rd May 1901. 
49. Stenothoe monoculoides (Montagu).

1804. Cancer (Gammarus) monoculoides, Mont., Trans. Linn. Soc., vol. xi. p. 4, pl. ii. fig. 3.

Habitat.-Not very common; the specimens in my collection were taken in Granton Harbour with a surface tow-net.

Family M E T O P I D Æ, T. R, R. Stebbing, $1899 .{ }^{1}$

Genus (31) Metopa, Boeck, 1870.

50. Metopa Alderi (Spence Bate).

1862. Montagua Alderi, Bate, Catal. Amphip. Brit. Mus., p. 57, pl. viii. fig. 6.

Habitat.-Firth of Forth, 1889; and taken subsequently at nearly all the Experimental Stations within the limits of the estuary. It has been also observed in the stomachs of Whitings captured in 1901.

51. Metopa borealis, G. O. Sars.

1882. Metopa borealis, G. O. Sars, Oversigt Norges Crust., i. p. 91, pl. iv. fig. 4.

Habitat._Dredged in South Bay, off Musselburgh, in 1888.

52. Metopa rubrovittata, G. O. Sars.

1882. Metopa rubrovittata, G. O. Sars, Oversigt Norges Crust., i. p. $90, \mathrm{pl}$. iv. figs, $2,2 a$.

Habitat.-Obtained in a bottom tow-net gathering collected at Station II. on 30th August 1894.

53. Metopa pusilla, G. O. Sars.

1892. Metopa pusilla, G. O. Sars, Crustacea of Norway, vol. i. p. 206, pl. xe. fig. 1.

Habitat.-Firth of Forth, at the following places in 1901, viz.:-At Stations III. and VII. in April, at Station III. in May, and off North Craig in July; but not more than one or two specimens were obtained in any single gathering. ${ }^{2}$

1 Cf. "Revision of Amphipoda," Ann. and Mag. Nat. Hist. for March, April, and September 1899.

${ }^{2}$ Cf. Twentieth F. B. Rept., pt. iii. p. 478 (1902). 
54. Metopa Bruzelii (Göes).

1865. Montagua Bruzelii, Göes, Crust. Amıphip. maris Spitzberg., Öfv. K. svenska Vet.-Akad. förhandl. (1865), p. 522, pl. xxxviii. fig. 10.

Habitat.-Firth of Forth, 1896; not common.

55. Metopa propinqua, G. O. Sars.

1892. Metopa propinqua, G. O. Sars, Crustacea of Norway, vol. i. p. 264, pl. xeiii. fig. 1 .

Habitat.-Dredged off Crail in 1892; rare.

56. Metopa norvegica (Lilljeborg).

1851. Leucothoë norvegica, Lillj., Bidr. til Norra Rysslands og Nor. Fauna (1848); K. Vet.-Akad.. Forhandl. (1851), vol. ii. p. 335 , pl. xx. fig. 4 .

1855. Montagua pollexiana, Spence Bate, Brit. Assoc. Report (1855), p. 57.

Habitat.-Newhaven (Henderson). Off the west side of Inchkeith, 1888. Dredged at the west end of Station III. in May, and off the North Craig in July, 1901. I find this species generally though sparingly distributed throughout the estuary.

\section{Genus (32) Sthenometopa, Norman. ${ }^{1}$}

57. Sthenometopa robusta (G. O. Sars).

1893. Metopa robusta, G. O. Sars, Crustacea of Norway, vol. i. p. 271, pl. xevi. fig. 1.

1894. ," , T. and A. Scott, Ann, and Mag. Nat. Hist. (6), vol. xiii. p. 184 (Feb. 1894).

Habitat.-Dredged at the west end of Station III. in May, and off the North Craig in July, 1901. The Rev. Canon Norman remarks (op. cit., p. 45) that Dr J. R. Henderson obtained this species in the Firth of Forth in 1884, but that T. and A. Scott were the first to record it as British. ${ }^{2}$

Genus (33) Metopella, G. O. Sars, 1892.

58. Metopella nasuta (Boeck).

1870. Metopa nasuta, Boeck, Crust. Amphip. borealia et aretica, p. 64 .

Habitat.-Taken in moderately deep water west of May

1 Cf. Norman, Natural History of E. Finmark (pt. 2); Ann. and Mag. Nat. Hist., Dec. 1902, p. 481.

${ }^{2}$ It would thus appear that when Henderson found his specimens the species was still undescribed. Sars did not describe it till 1893. 
Island, in 1892. The generic name Metopella was proposed by G. O. Sars in his remarks on a closely allied species, M. longimana, Boeck. ${ }^{1}$

Family C R E S S D E, Stebbing, 1899.

Genus (34) Cressa, Boeck, 1870.

59. Cressa dubia (Spence Bate).

1862. Danaia dubia, Bate, Catal. Amphip. Brit. Mus., p. 59, pl. x. fig. 1.

1870. Cressa Schiödter, Boeck, Crust. Amphip. borealia et arctica, p. 65 .

Habitat.-Taken at Station V. in February 1892. Dredged at Station III. on 23rd May 1901; apparently not very common.

Family LEUCOTHOID

Genus (35) Leucothoë, Leach, 1814.

60. Leucothoë Lilljeborgii, Boeck.

1860. Leucothoë Lilljeborgii, Boeck, Forhandl. Skand. Natur. 8de Möde, p. 653.

Habitat.-Obtained in the neighbourhood of the Bass Rock, rare (1894). Dredged off the north-west end of Inchkeith on 23rd May 1901. Found also in the stomach of a Sharptailed Lumpenus, Lumpenus lampretiformis, captured in the estuary during the same month.

Family EDICERID 㞼.

Genus (36) Monoculodes, Stimpson, 1853.

61. Monoculodes carinatus, Spence Bate.

1862. Monoculodes carinatus, Bate, Catal. Amphip. Brit. Mus., p. 104, pl. xvii. fig. 2.

Habitat.-Dredged in Largo Bay, off St Monans, and near Fidra Island; not common.

1 Cf. Crustacea of Norway, vol. i. p. 274. 
Genus (37) Perioculodes, G. O. Sars, 1892.

62. Perioculodes longimanus (Bate and Westwood).

1869. Monoculodes longimanus, B. and W., Brit. Sessile-eyed Crustacea, p. 507.

Habitat.-Dredged off Bo'ness, 1888; Largo Bay, 1890, frequent. Station V., 24th April, and in the neighbourhood of the Bass Rock in 20 fathoms, 28th June 1901. Also found in the stomachs of small Whiting captured in the estuary in May 1901.

Genus (38) Pontocrates, Boeck, 1870.

63. Pontocrates arenarius (Spence Bate).

1858. Kröyera arenaria, Bate, Trans. Tyneside Field Club, vol. iv., pt. i. (1858) p. 15, pl. ii. fig. 1.

1862. " , , Bate and Westw., Brit. Sessile-eyed Crust., vol. i. p. 173.

Habitat.-Shore east of Burntisland, frequent, burrowing in the wet sand, near low-water, 1889. Dredged in shallow water, off Musselburgh, in May 1901.

64. Pontocrates altamarinus (Bate and Westwood).

1862. Kröyera altamarina, B. and W., Brit. Sessile-eyed Crustacea, vol. i. p. 177.

1895. Pontocrates, altamarinus, G. O. Sars, Crust. of Norw., vol. i. p. 695 (Suppl.), pl. vii. fig. 2.

Habitat.-Dredged off Bo'ness; not common.

Genus (39) Synchelidium, G.' O. Sars, 1892.

65. Synchelidium brevicarpum (Bate and Westwood).

1868. Kröyera brevicarpa, B. and W., Brit. Sessile-eyed Crustacea, vol. ii. (Appendix), p. 508.

Habitat.-Dredged in Largo Bay in 1889; at Station VI. (off St Monans) in April 1901; and at other places and dates; not common.

Genus (40) Halimedon, Boeck, 1870.

66. Halimedon parvimanus (Bate and Westwood).

1863. Edicerus parvimanus, B. and W., op. cit., vol. i. p. 161.

1870. Halimedon Mïlleri, Boeck, Crust. Amphip. bor, et arct., p. 89.

Habitat.-Dredged at Station V. in February 1892, and 
subsequently in other parts of the estuary. It was again dredged at Station V. in April 1901, and was also found in the stomachs of Sharp-tailed Lumpenus captured in the neighbourhood of that station in May of the same year.

\section{Family PLEUSTID E.}

Genus (41) Paramphithoë, Bruzelius, 1859.

67. Paramphithoë bicuspis (Kröyer).

1838. Amphithoë bicuspis, Kröyer, Grönlands Amphipoder, p. 45, pl. i. fig. 1.

Habitat.-Newhaven, from fishermen's lines (Henderson). Dredged off the east side of Inchkeith on 23rd May 1901. The species appears to be generally though sparingly distributed throughout the seaward part of the estuary.

68. Paramphithö̈ monocuspis, G. O. Sars.

1892. Paramphithoë monocuspis, G. O. Sars, op. cit., vol. i. p. 351, pl, exxiii. fig. 2.

Habitat.-Firth of Forth (Henderson, 1884; cf. Twelfth F. B. Rept., pt. iii. p. 264, 1894). Dredged off the east side of Inchkeith, and at the north-west end of the island, in May 1901.

69. Paramphithoё assimilis, G. O. Sars.

1882. Paramphithoë assimilis, G. O. Sars, Oversigt af Norges Crust., vol. i. p. 99 , pl. v. fig. 1 .

Habitat.-Dredged between Inchkeith and May Island, found adhering to zoophytes brought up in the dredge, 1894. Dredged at Station VI. (off St Monans), 22nd May 1901; rare.

Genus (42) Sympleustes, Stebbing, 1899. ${ }^{1}$

70. Sympleustes latipes (M. Sars).

1858. Amphithoë latipes, M. Sars, Forhandl. Vid. Selsk. Chr. (1858), p. 139.

1890. Amphithopsis latipes, T. Scott, Eighth F. B. Rept., pt. iii. p. 328.

1893. Paraplenstes latipes, G. O. Sars, Crustacea of Norway, vol. i. p. 360 , pl. exxvii.

Habitat.-Several specimens, prettily coloured, were ${ }^{1}$ Cf. Stebbing, "Revision of Amphipoda," Ann. and Mag. Nat. Hist., Sept. 1899 , p. 209. 
obtained adhering to a tuft of Antennularia antennina dredged off the east side of Inchkeith in August 1889, and at Station V. in September 1890.

Family E P I M E I D Æ.

Genus (43) Epimeria, A. Costa, 1851.

71. Epimeria cornigera (Fabricius).

1779. Gammarus corniger, Fabr., Reise nach Norwegen, p. 83.

1863. Acanthonotus Owenii, Bate and Westw., Brit. Sessile-eyed Crust., vol. i. p. 232.

Habitat.-Dredged at Station III. in 1890, and off the North Craig on 4th July 1901; not common.

Family I P H I M E D I D

Genus (44) Iphimedia, Rathke, 1843.

72. Iphimedia obesa, Rathke.

1843. Iphimedia obesa, Rathke, Nova Acta Acad. Leopold, t. xx. p. 85.

Habitat.-Newhaven, many specimens, dredged to the east of Inchkeith (Henderson). Granton Harbour, 1888; Station V., January 1892. Generally distributed throughout the estuary, but usually not very common.

73. Iphimedia minuta, G. O. Sars.

1882. Iphimedia minuta, G. O. Sars, Oversigt af Norges Crust., vol. i. p. 100, pl. v. fig. 2.

Habitat.-Dredged at the north end of Inchkeith and other parts of the estuary; not common. Dredged at Station III. on 23rd May 1901.

Family SYRRHOID E.

Genus (45) Argissa, Boeck, 1870.

74. Argissa hamatipes (Norman).

1869. Syrrhoë hamatipes, Norman, Brit. Assoc. Rept. (1868), p. 279.

1870. Argissa typica, Boeck, Crust. Amphip. bor. et arctic., p. 45.

Habitat.-Taken at various places during the autumn and 
winter of 1892. Taken at Station V. in April, and at Station VI. in May, 1901.

\section{Family L A P H X S T I I}

Genus (46) Laphystius, Kröyer, 1842.

\section{Laphystius sturionis, Kröyer.}

1842. Laphystius sturionis, Kröyer, Naturh. Tidsskr., 1 R., Bd. iv. p. 157.

1855. Darwinia compressa, Spence Bate, Brit. Assoc. Rept. (1855), p. 58.

Habitat.-Parasitic on various fishes; a considerable number of specimens have at different times been observed adhering to Angler-fishes, Lophius piscatorius, Linn., captured in the estuary.

Family CALL I O P I D $A$.

Genus (47) Apherusa, A. O. Walker, 1891.

76. Apherusa bispinosa (Spence Bate).

1857. Dexamine bispinosa, Bate, Ann. and Mag. Nat. Hist. (2), vol. xx. p. 142.

1863. Atylus bispinosus, Bate and Westw., Brit. Sessile-eyed Crust., vol. i. p. 250.

1893. Apherusa bispinosa, G. O. Sars, Crustacea of Norway, vol. i. p. 439 , pl. cliii. fig. 1 .

Habitat.-South Bay, 1888, and subsequently in other parts of the estuary. Taken in 20 fathoms in the neighbourhood of the Bass Rock, 28th June 1904.

77. Apherusa cirrus (Bate).

1862. Pherusa cirrus, Bate, Cat. Amphip. Brit. Mus., p. 143, pl. xxvii. fig. 6 .

1870. Halirages borealis, Boeck, Crust. Amphip. borealia et arctica, p. 116.

1893. Apherusa borealis, G. O. Sars, op. cit., vol. i. p. 441, pl. clv. fig. 2.

Habitat.-Generally distributed in the Forth; recent records include Station V., where it was taken on 24th April 1901, and near the Bass Rock on 28th June 1904. 
78. Apherusa Jurinii (M.-Edwards).

1830. Amphithoë Jurinii, M.-Edwards, Ann. Sci. Nat., vol. xx. p. 376.

1862. ? Pherusa fucicola, Leach (Bate, Catal. Amphip. Brit. Museum, p. 145, pl. xxvii. fig. 10, not fig. 9).

1893. Apherusa Jurinii, G. O. Sars, op. cit., vol. i. p. 445, pl. clvii. fig. 1.

Habitat.-? Newhaven, on fishermen's lines (Henderson, 1884, as Pherusa fucicola). Several specimens were dredged in the estuary in 1887 (Mihi). I am doubtful if Henderson's record really refers to $A$. Jurinii, but do not know what else to refer it to.

Genus (48) Calliopius, Lilljeborg, 1865.

79. Calliopius Rathkei (Zaddach).

1844. Amphithoë Rathkei, Zaddach, Synops. Crust. Pruss. Prodrom., p. 6.

1862. Calliope grandoculus, Bate, Catal. Amphip. Brit. Mus., p. 149, pl. xxviii. fig. 4 .

Habitat.-Firth of Forth, near Dunbar, at the mouth of the estuary, 1894. This is probably only a smaller form of the next species.

80. Calliopius loeviusculus (Kröyer).

1838. Amphithoë lceviusculus, Kröyer, Grönlands Amphipoder, p. 6.

1863. Calliope loeviscula, Bate and Westw., Brit. Sessile-eyed Crust., vol. i. p. 259.

Habitat.-Not uncommon in various parts of the estuary from above Queensferry to North Berwick, especially inshore amongst Algæ.

\section{Family A T Y LID}

Genus (49) Paratylus, G. O. Sars, 1893. .

81. Paratylus Swammerdami (M.-Edwards).

1830. Amphithoë Swammerdami, M.-Edw., Ann. des Sci. Nat. (1), vol. xx. p. 378 .

1863. Atylus Swammerdami, Bate and Westw., op. cit., vol. i. p. 247.

Habitat.-Firth of Forth; moderately common and generally distributed. 
82. Paratylus falcatus (Metzger).

1871. Atylus falcatus, Metzger, Wirbelosen Meeresthiere der ostfriesischen Kuste, Beitr. II. p. 9.

Habitat.-Firth of Forth, 1896; several specimens in my collection.

83. Paratylus uncinatus, G. O. Sars.

1882. Atylus uncinatus, G. O. Sars, Oversigt af Norges Crust., p. 102.

Habitat.-Off Aberlady, 12th December 1892, and again in the spring of 1893. This form does not appear to be very rare, but it may be easily passed over as a more common species.

84. Paratylus vedlomensis (Bate and Westwood).

1863. Dexamine Vedlomensis, Bate and Westw., Brit. Sessile-eyed Crust., vol. i. p. 242.

Habitat.-Taken sparingly in several localities between Inchkeith and May Island. Dredged off St Monans, 22nd May 1901.

Family DEX A M I I D

Genus (50) Dexamine, Leach, 1814.

85. Dexamine spinosa (Montagu).

1813. Cancer gammarus spinosus, Mont., Trans. Linn. Soc., vol. xi. p. 3, pl. ii. fig. 1.

1863. Dexamine spinosa, Bate and Westw., op. cit., vol. i. p. 237.

Habitat.-Obtained at low-water at Prestonpans (Cunningham ; Leslie and Herdman). Off Musselburgh, 1888. This appears to be a rare species in the Forth estuary.

86. Dexamine Thea, Boeck.

1870. Dexamine Thea, Boeck, Crust. Amphip. bor. et arct., p. 107.

Habitat.-Firth of Forth, 1896; scarce.

Genus (51) Tritæta, Boeck, 1876.

87. Tritceta gibbosa (Spence Bate).

1862. Atylus gibbosus, Bate, Catal. Amphip. Brit. Mus., p. 137, pl. xxvi. fig. 3.

Habitat.-Firth of Forth, 1896 ; not common. 


\section{Genus (52) Guernea, Chevreux, 1887.}

88. Guernea coalita (Norman).

1868. Helleria coalita, Norman, Ann. and Mag. Nat. Hist. (4), vol. ii. p. 418, pl. xxii. fig. 8 ; pl. xxiii. figs. 1-6.

1887. Guernea coalita, Chevreux, Bull. Soc. Zool, de France, vol. xii. p. 16 (separate copy).

Habitat.-Dredged off St Monans, 12 to 14 fathoms, 1889-90. In a gathering of dredged material from the same place, collected on 22nd May 1901; not uncommon.

Family M E L P H I D I P P I D Æ.

Genus (53) Melphidippella, G. O. Sars, 1893.

89. Melphidippella macera (Norman).

1869. Atylus macer, Norman, Brit. Assoc. Report (1868), p. 280.

Habitat.-Taken with bottom tow-net at Station V., 16th April 1892. At the same Station on 24th April, and at Station VI. on 22nd May 1901; not common.

Family G A M M A R I D

Genus (54) Amathilla, Spence Bate, 1863.

90. Amathilla homari (J. C. Fabricius).

1798. Gammarus homari, Fabr., Entom. Syst. Suppl., p. 418.

1863. Amathilla Sabini, Bate and Westw., Brit. Sessile-eyed Crust., vol. i. p. 361.

Habitat.-Dredged near May Island, 1889. Also at Station IV., 23rd December 1892, and Station VII., 23rd February 1894 ; rare in the adult stage.

Genus (55) Gammarus, Fabricius, 1776.

91. Gammarus marinus, Leach.

1815. Gammarus marinus, Leach, Trans. Linn. Soc., vol. xi. p. 359. 1863.

" Bate and Westw., op. cit., vol. i. p. 370.

Habitat.-Taken near Culross, west of Queensferry, 1892. Between tide-marks, Dalmeny shore, November 1904 (Evans). Generally but sparingly distributed throughout the estuary. 
92. Gammarus Duebeni, Lilljeborg.

1851. Gammarus Duebeni, Lillj., Öfvers af K. Svenska Vet.-Acad. Forhandl., p. 22.

Habitat.-Taken in the brackish water lagoon at the mouth of the Cocklemill Burn, near Largo, 1896; also in brackish water pools on May Island, 13th June 1893.

93. Gammarus locusta (Linné).

1767. Cancer locusta, Linn., Syst. Nat., ed. xii., vol. ii. p. 1055.

1863. Gammarus locusta, Bate and Westw., Brit. Sessile-eyed Crust., vol. i. p. 378 .

Habitat.-Common, especially in the littoral zone.

94. Gammarus pulex (De Geer).

1752. Squilla ponce, De Geer, Mem. pour Servir a l'Hist. des Insects, vol. vii. p. 525, pl. 33.

1777. Astacus pulex, Pennant, British Zoology, vol. iv. p. 17.

Habitat.-Common in shallow fresh-water lakes, slow streams, ditches, etc., throughout the district.

\section{Genus (56) Melita, Leach.}

195. Melita obtusata (Montagu).

1804. Cancer gammarus obtusatus, Mont., Trans. Linn. Soc., vol. ix. p. 5, pl. ii. fig. 7.

1863. Melita obtusata, Bate and Westw., vol. i. p. 407.

Habitat.-Moderately frequent throughout the estuary.

96. Melita dentata (Kröyer).

1842. Gammarus dentatus, Kröyer, Naturh. Tidsskr. 1 R., vol. iv. p. 159.

1862. Megamoera dentata, Bate, Catal. Amphip. Brit. Mus., p. 225, pl. xxxix. fig. 4.

Habitat.-Taken in moderately deep water (28 fathoms) at the mouth of the estuary in January 1890; rare. Only two specimens, one partly dissected, are in my collection.

1 Two specimens of Melita gladiosa, Bate, were in 1888 recorded by me from Largo Bay (cf. Sixth F. B. Rept., part iii. p. 247), but they were probably merely well-developed males of $M$. obtusata. 
Genus (57) Mæra, Leach, 1813.

97. Moera Othonis (M.-Edwards).

1830. Gammarus Othonis, M.-Edw., Ann. des Sci. Nat., vol. xx. p. 373 , pl. x. fig. 11 ( $\$$ ).

1863. Megamcera Othonis, Bate and Westw., op. cit., vol. i. p. 405 ( $\$$ ).

1863. " (?) longimana, idem, ibidem, p. 403 ( ठ ).

Habitat.-Dredged in South Bay in 1888, and off the east side of Inchkeith in 1891; rare.

98. Moera Loveni (Bruzelius).

1869. Gammarus Loveni, Bruz., Skand. Amphip. Gamm., p. 59, fig. 9.

1868. Mora Loveni, Norman, Ann. and Mag. Nat. Hist. (4), vol. ii. p. 416, pl. xxi. figs. 11, 12 .

1889. " " , idem, ibidem (6), vol. iv. p. 127 (Aug. 1889).

Habitat.-A single specimen of this large species was dredged a short distance west of Inchkeith on 11th November 1887. Another specimen was obtained in the stomach of a Lemon Sole (Pleuronectes microcephalus) captured at Station IX. on 5th August 1890, and a third in the stomach of a Witch Sole (Pleuronectes cynoglossus) captured at Station V. on 28th June 1901.

1 99. Moera tenuimana (Bate).

1862. Gammarus tenuimanus, Bate, Catal. Amphip. Brit. Mus., p. 214, pl, xxxviii. fig. 2.

1868. Moera Batei, Norman, Ann. and Mag. Nat. Hist. (4), vol. ii. p. 416, pl. xxii. figs. 1-3 ( $\$$ ).

1869. Megamoera multidentata, Bate and Westw., op. cit., vol, ii. p. $515(\delta)$.

Habitat.-Firth of Forth, captured in 1895 ; rare. (Cf. Fourteenth F. B. Rept., pt. iii. p. 160, 1896.)

Genus (58) Megaluropus, Norman, 1889.

100. Megaluropus agilis, Norman.

1889. Megaluropus agitis, Norman, Ann. and Mag. Nat. Hist. (6), vol. iii. p. 446, pl. xviii. figs. 1-10 (June 1889); op. cit., vol. iv. p. 122, pl. x. figs. 15-17 (Aug. 1889).

Habitat.-Taken in Largo Bay, 1888-90; frequent. Dredged off Musselburgh in May 1891, and at Stations V. and VI. in April 1901.

${ }^{1}$ See A. O. Walker's remarks on this and other species, Ann. and Mag. Nat. Hist. for June 1895 (Ser. 6, vol. xv. pp. 464-476). 
Genus (59) Cheirocratus, Norman, 1865.

101. Cheirocratus Sundewalli (Rathke).

1843. Gammarus Sundewalli, Rathke, Nova Acta Acad. Leopold, vol. xx. p. 65, pl. iii. fig. 2.

Habitat.-Taken at Station II., 14th November 1888; and subsequently, but sparingly, at other parts of the estuary. Dredged off the east side and at the north-west end of Inchkeith in May 1901; also found in the stomach of a Long Rough Dab (Platessoides limandoides) captured in the Forth during the same month.

\section{Cheirocrates intermedius, G. O. Sars.}

1894. Cheirocrates intermedius, G. O. Sars, op. cit., vol. i. p. 527, pl. clxxxvi. fig. 1 .

1896. , , " T. Scott, Fourteenth F. B. Rept., pt. iii. p. 160, pl. iv. fig. 7 .

Habitat.-Firth of Forth, taken in 1889 and 1893 (but not recorded till 1896); rare.

\section{Cheirocrates assimilis (Lilljeborg).}

1851. Gammarus assimilis, Lillj., Öfvers af K. Svenska Vet.-Acad. Forhandl. (1851), p. 23.

1865. Cheirocrates mantis, Norman, Nat. Hist. Trans. Northumb. and Durham, vol. i. p. 13, pl. vii. figs. 14, 15.

Habitat.-Dredged off the west side of Inchkeith in February 1894; at the north end of the same island on 23rd January 1896; and at Station III. on 23rd May 1901; moderately rare.

\section{Family L I L L JEB O R G I I D 死.}

Genus (60) Lilljeborgia, Spence Bate, 1862.

104. Lilljeborgia Kinahani (Spence Bate).

1862. Phoedra Kinahani, Bate, Catal. Amphip. Brit. Mus., p. 119, pl. xxi. fig. 1.

Habitat.-Dredged at Station VI. and Station III., and also at the north-west end of Inchkeith, in May 1901, but only a few specimens were obtained altogether. 


\section{Family A o R I $\approx$.}

Genus (61) Microdeutopus, A. Costa, 1853.

105. Microdeutopus anomalus (Rathke).

1843. Gammarus anomalus, Rathke, Nova Acta Acad. Leopold, vol. xx. p. 63 , pl. vi. fig. 7 .

Habitat.-Firth of Forth, 1893; rare.

Genus (62) Aora, Kröyer, 1844.

106. Aora gracilis, Spence Bate.

1855. Lonchomerus gracilis, Bate, Brit. Assoc. Rept. (1855), p. 58.

1862. Aora gracilis, idem, Catal. Amphip. Brit. Mus., p. 160, pl. sxix. fig. 7.

Habitat.-Newhaven; many specimens. Both sexes taken off Fidra (Henderson, 1884). I have dredged it off Elie, and one or two other places, but usually in small numbers.

Genus (63) Lembos, Spence Bate, 1856.1

107. Lembos Websteri, Spence Bate.

1857. Lembos Websteri, Bate, Ann. and Mag. Nat. Hist. (2), vol. xix. p. 142.

Habitat.-Dredged at Station V., 24th April 1901; rare.

108. Lembos longipes (Lilljeborg).

1852. Gammarus longipes, Lillj., Öfvers af K. Svenska Vet.-Acad. Forhandl. (1852), p. 10.

Habitat.-Dredged off St Monans, 19th June 1893 and 22nd May 1901; rare.

\section{Family P н О T ID}

Geuus (64) Protomedeia, Kröyer, 1842.

109. Protomedeia fasciata, Kröyer.

1842. Protomedeia fasciata, Kröyer, Naturh. Tidsskr., vol. iv. p. 154.

Habitat.-Captured near May Island, October 1894.

${ }^{1}$ Cf. Rev. 'T. R. R. Stebbing, "Notes on Amphipoda, Old and New," in Ann. and Mag. Nat. Hist. for September 1895. 
Found in the stomachs of Gurnards (Trigla gurnardus), as well as in the stomachs of sharp-tailed Lumpenus, small Whitings, and Long Rough Dabs, captured in the estuary in April and May 1901.

\section{Genus (65) Leptocheirus, Zaddach, 1844.}

1110. Leptocheirus hirsutimanus (Spence Bate).

1862. Protomedeia hirsutimanus, Bate, Catal. Amphip. Brit. Mus., p. 168, pl. xxx. fig. 6 .

1894. Leptocheirus pilosus, G. O. Sars, op. cit., vol. i. p. 556, pl. cxevii. (not L. pilosus, Zaddach).

Habitat.-Dredged off Elie Ness in 17 fathoms in 1888. Dredged off Inchkeith in 1890, and again in 1894; and at Station III. and Station VI. in May 1901. In this species the accessory appendage of the superior antennæ is composed of about six joints.

111. Leptocheirus pilosus, Zaddach.

1844. Leptocheirus pilosus, Zadd., Synopsis Crustaceorum Prussicorum Prodr., p. 8.

?1869. Protomedeia pectinata, Norman, Brit. Assoc. Rept. (1868), p. 283.

1895. Leptocheirus pilosus, A. O. Walker, Trans. Liverpool Biol. Soc, vol. ix. p. 310.

Habitat.-Dredged in the Firth of Forth in 1893 and 1894. Over a dozen specimens of this species were obtained in some material dredged off St Monans on 22nd May 1901. In this species the accessory appendage of the superior antennæ is two-jointed. A female specimen, with ova, measured a little over three millimetres.

Genus (66) Gammaropsis, Lilljeborg, 1854.

112. Gammaropsis maculata (Johnston).

1828. Gammarus maculatus, Johnston, Contrib. to Brit. Fauna, Zool. Jour., vol. iii. p. 176.

1894. Gammaropsis erythrophthalma, G. O. Sars, Crustacea of

Norway, vol. i. p. 558, pl. cxcviii.

1900. ", maculata, Chevreux, Albert Ier Prince de Monaco, Camp. Scient. (Amphipoda), p. 92.

Habitat.-Dredged off the west side of Inchkeith in 1888.

${ }^{1}$ Cf. A. O. Walker, "Revis. of the Amphip. of the L. M. B. C. District," Trans. Liverpool Biol. Soc., vol. ix. p. 310 (1895). 
Taken at Station V. in December 1890; and subsequently, but always sparingly, in various other parts of the estuary.

113. Gammaropsis nana, G. O. Sars.

1894. Gammaropsis nana, G. O. Sars, op. cit., vol. i. p. 561, pl, excix. fig. 2.

Habitat.-Taken at one or two places in the estuary in 1890. Dredged at Station IV. in April, and at Station III. in May, 1901.

Genus (67) Megamphopus, Norman, 1869.

\section{Megamphopus cornutus, Norman.}

1869. Megamphopus cornutus, Norman, Brit. Assoc. Rept. (1868), p. 282.

Habitat.-Firth of Forth, 1896 ; dredged at Station III. in May 1901.

Genus (68) Microprotopus, Norman, 1866.

115. Microprotopus maculatius, Norman.

1866. Microprotopus maculatus, Norman, Brit. Assoc. Rept. (1866), p. 203.

Habitat.-Dredged in Largo Bay in 1891, and subsequently in other parts of the estuary, but not very common.

Genus (69) Photis, Kröyer, 1842.

116. Photis longicaudatus (Bate and Westwood).

1863. Eiscladus longicaudatus, B. and W., Brit. Sessile-eyed Crust., vol. i. p. 412.

Habitat.-Firth of Forth, dredged off St Monans in 1892; also west of Queensferry in April, and at Stations III, and VI. in May, 1901.

\section{Genus (70) Podoceropsis, Boeck, 1860}

117. Podoceropsis Sophice, Boeck.

1860. Podoceropsis Sophice, Boeck, Forh. Ved. de Skand. Naturf. 8 de Möde, p. 666.

1862. Nonia tuberculosa, Bate, Catal. Amphip. Brit. Mus., p. 271, pl. xlvi. fig. 2.

Habitat.- "Dredged to the east of Inch Mickery, also 
south-west of Inchkeith" (Henderson, 1884). This species I have not met with in the Firth of Forth.

\section{Podoceropsis excavata (Spence Bate).}

1862. Nonia excavata, Bate, op. cit., p. 272 , pl. xlvi. fig. 4 ( $q$ ).

1862. " rimapalma, idem, ibidem, p. 272, pl. xlvi. fig. 3 (

Habitat.- "With the last in both localities" (Henderson). Dredged in Largo Bay, Kirkcaldy Bay, at Station III., and elsewhere; generally though sparingly distributed.

Family A M P I THOID

Genus (71) Amphithoë, Leach, 1813.

119. Amphithoё rubricata (Montagu).

1804. Cancer (Gammarus) rubricatus, Mont., T'rans. Linn. Soc., vol. ix. p. 99, pl. v. fig. 1.

1856. Amphithoë littorina, Bate, Brit. Assoc. Rept. (1855), p. 59.

Habitat.-Dredged off Musselburgh and off the west side of May Island in 1887-88. Subsequently in other parts of the estuary, especially in shallow water amongst Algæ.

Genus (72) Pleonexes, Spence Bate, 1857.

120. Pleonexes gammaroides, Spence Bate.

1857. Pleonexes gammaroides, Bate, Ann. and Mag. Nat. Hist. (2), vol. xix. p. 147 ( $\delta$ ).

1857. Sunamphithoё hamulus, idem, ibidem, p. 148 ( $q$ ).

Habitat.-Obtained off Pittenweem amongst trawl refuse, and between tide-marks near Portobello, 1887-88.

\section{Family I S C H Y R O C E R I D}

Genus (73) Ischyrocerus, Kröyer, 1838.

121. Ischyrocerus minutus, Lilljeborg.

1850. Ischyrocerus minutus, Lillj, Kgl. Svenska Vet.-Acad. Handl. (1850), p. 335.

Habitat.-Taken in various parts of the estuary. The specimens in my collection were obtained in 1892. 
${ }^{1}$ Genus (74) Jassa, Leach, 1813.

122. Jassa falcata (Montagu).

1804. Cancer (Gammarus) falcatus, Mont., Trans. Linn. Soc., vol, ix. p. 100, pl. v. figs. $1,2$.

Habitat.-Dredged off Musselburgh in 1888 and 1891 ; and subsequently, though sparingly, in other parts of the estuary.

\section{Jassa pusilla (G. O. Sars).}

1894. Podocerus pusillus, G. O. Sars, Crustacea of Norway, vol. i. p. 596, pl. ecxiii. fig. 1 .

Habitat.--Firth of Forth, 1887, and also in 1889, when the specimens in my collection were obtained. More recently it has been dredged at Station III., and at the north-west end of Inchkeith on 23rd May 1901.

2124. Jassa Herdmani (A. O. Walker).

1893. Podocerus Herdmani, A. O. Walker, Sixth Rept. L. M. B. C., p. 37 , fig. 13.

1894. " odontonyx, G. O. Sars, op. cit., vol. i. p. 597, pl. ecxiii. fig. 2.

Habitat.-Off' St Monans, 19th June 1893. This form, which I have observed on several occasions, resembles in some respects the Jassa pusilla (G. O. Sars); and, as A. O. Walker suggests, may be only a form of it. (It is probable that the species of Jassa mentioned above may have to be removed to another genus.)

125. Jassa pelagica, Leach.

1814. Jassa pelagica, Leach, Edin. Encyclop., vol. vii. p. 433.

1843. Podocerus capillatus, Rathke, Nova Acta Cæsar. Leop. Carol. Nat. Cur., vol. xx. p. 89 , pl. iv. fig. 8.

Habitat.-Firth of Forth, off Musselburgh, in April 1891, and very sparingly on one or two other occasions.

${ }^{1}$ Cf. Rev. T. R. R. Stebbing, "On the true Podocerus, and some New Genera of Amphipoda," Aun. and Mag. Nat. Hist. (7), vol. iii p. 237 et seq. (March 1899). Cf. also Chevreux, "Result. Canıl. Scient. Albert Ier Prince de Monaco," Amphipoda, Addenda, p. 165 (1900).

${ }^{2}$ Cf. Rev. T. R. R. Stebbing, op. cit., p. 240. 
Genus (75) Erichthonius, M.-Edwards, 1830.

\section{Erichthonius abditus (Templeton).}

1836. Cerapus abditus, Templ., Trans. Ent. Soc., vol. i. p. 188, pl. xx. fig. 5 .

1862. Dercothoë punctata, Bate, Catal. Amphip. Brit. Mus., p. 260, pl. xliv. fig. 10.

Habitat.-South Bay, 1888; Kirkcaldy Bay, 27th March 1891 ; Station III., 25th May 1901.

127. Erichthonius deformis, M.-Edwards.

1830. Erichthonius deformis, M.-Edw., Ann. Sci. Nat., vol. xx. p. 382.

1863. Cerapus deformis, Bate and Westw., Brit. Sessile-eyed Crust., vol. i. p. 457.

Habitat.-Dredged near the Bass Rock (Metzger). Dredged in Suuth Bay in 1887. Obtained in the stomachs of small Whitings and Butter-fishes captured in the estuary in May 1901.

128. Erichthonius Hunteri (Spence Bate).

1862. Cerapus Hunteri, Bate, Catal. Amphip. Brit. Mus., p. 264, pl, xlv. fig. 3.

1896. Erichthonius Hunteri, T. Scott, Fourteenth F. B. Rept., pt. iii. p. 161, pl. iv. fig. 8.

Habitat.-Firth of Forth, generally though sparingly distributed. The specimens in my collection were obtained in 1887 and 1894. Specimens of E. Hunteri were dredged at Station VII. in April, and at Station III. in May, 1901.

Family C O R O PHIID A.

Genus (76) Cerapus, Say, 1817.

129. Cerapus crassicornis (Spence Bate).

1855. Siphonoecetes crassicornis, Bate, Brit. Assoc. Rept. (1855), p. 59.

1863. ", ", Bate and Westw., Brit. Sessile-eyed Crust., vol, i. p. 496.

Habitat.-Firth of Forth; a single specimen (still in my collection) was obtained in a bottom tow-net gathering on 30th May 1892. This specimen, in its tube of hardened 
mud, with which it was able to move freely about, had a close resemblance to a small insect larva.

Genus (77) Siphonoëcetes, Kröyer.

130. Siphonoëcetes Whitei (Gosse).

1853. Cerapus Whitei, Gosse, Naturalist's Rambles on Devonshire Coast, p. 282, pl. xxii. figs. 12-14.

1870. Siphonoëcetes Colletti, Boeck, Crust. Amphip. bor. et arct., p. 258.

Habitat.-Frequent in material dredged in Largo Bay in 1890 , and occasionally in other parts of the estuary.

Genus (78) Corophium, Latreille, 1807.

131. Corophium grossipes (Linné).

1767. Cancer grossipes, Linn., Syst. Nat., ed. xii., vol. ii. p. 1050.

1775. Gammarus longicornis, Fabr., System. Entom., vol. ii. p. 515.

1863. Corophium longicorne, Bate and Westw., op. cit., vol. i. p. 493.

Habitat.-Dunbar (Robertson). "Very abundant on the mud flat at Morrison's Haven" (Cunningham). ${ }^{1}$ Brackish water pools at Aberlady in 1895 .

132. Corophium crassicorne, Bruzelius.

1859. Corophium crassicorne, Bruz., Skand. Amphip. Gamm., p. 15, pl. i. fig. 2 .

Habitat.-Taken off Musselburgh in 1888. Aberdour Bay, November 1893. (Cf. also Fourteenth F. B. Rept., pt. iii. p. 161, 1896.)

133. Corophium Bonelli, M.-Edwards.

1830. Corophium Bonelli, M.-Edw., Ann. Sci. Nat., vol. xx. p. 385.

Habitat.-Taken near Dunbar in 1894. Dredged at Station III. in May 1901.

134. Corophium affine, Bruzelius.

1859. Corophium affine, Bruz., op. cit., p. 16.

1869. ", tenuicorne, Norman, Brit. Assoc. Rept. (1868), p. 286.

Habitat.-A single specimen dredged off Fidra, October

1 Cf. Invertebrate Fauna, by Leslie and Herdman, pp. 44-106 (1881). 
1884 (Henderson). Dredged off Inchkeith; in Kirkcaldy Bay, and other places, but seldom more than one or two specimens in any single gathering.

Genus (79) Unciola, Say, 1818.

\section{Unciola planipes, Norman.}

1865. Unciola planipes, Norman, Nat. Hist. Trans. Northumb. and Durham, vol. i. p. 14, pl. vii. figs. 9-13.

Habitat.-Firth of Forth, dredged 22nd November 1889, and on one or two subsequent occasions; rare.

\section{Family D U L I C H I I}

Genus (80) Dulichia, Kröyer, 1845.

136. Dulichia porrecta, Spence Bate.

1862. Dulichia porrecta, Bate, Catal. Amphip. Brit. Mus., p. 348. pl. liv. fig. 9.

Habitat.--Taken off Musselburgh in April 1891. Dredged at Station III., and at the north-west end of Inchkeith, on 23rd May 1901. It was also obtained in the stomachs of small Whitings captured in the Forth during the same month.

137. Dulichia monacantha, Metzger.

1873. Dulichia monacantha, Metz., Nordseef. der Pommerania, Crust., p. 226, pl. vi. fig. 6 .

1898.

T. Scott, Ann. Scot. Nat. Hist. (Jan. 1898), p. 55.

Habitat.-Dredged at Station V. on 24th April, and on the 29 th at Station VII., 1901. It was also obtained in the stomachs of a few of the fishes captured in Forth in April and May 1901, and which were sent for examination to the laboratory at Bay of Nigg, Aberdeen.

138. Dulichia falcata, Spence Bate.

1857. Dulichia falcato, Bate, Ann. and Mag. Nat. Hist., vol. xx. p. 526.

Habitat.-Taken with surface tow-net in Granton Harbour, 26th November 1887. Dredged near Inchkeith on 11th April 1892; and at Station V. on 24th April 1901. Obtained also in the stomachs of fishes. 


\section{Caprellidea.}

\section{Family CA P R E L L I D F.}

Genus (81) Phtisica, Slabber, 1749.

139. Phtisica marina, Slabber.

1749. Phtisica marina, Slabber, Natuurkundige verslustigingen, etc., p. 79.

1814. Proto pedata, Leach, Edin. Encyclop., vol. vii. p. 433.

Habitat.-Newhaven, on fishermen's lines, not uncommon (Henderson). Dredged in South Bay in 1888; and subsequently at other parts of the estuary; and also obtained in the stomachs of small fishes captured in the Forth.

\section{Genus (82) Protella, Dana, 1852.}

140. Protella phasma (Montagu).

1804. Cancer phasma, Mont., Trans. Linn. Soc., vol. vii. p. 66, pl. vi. fig. 3 .

1868. Protella phasma, Bate and Westw., Sessile-eyed Crust., vol. ii. p. 45.

Habitat.-Firth of Forth (Goodsir). Dredged in South Bay in 1888, and again in 1892; and at Station III. on 23rd May 1901.

Genus (83) Pariambus, Stebbing, 1888.

141. Pariambus typicus (Kröyer).

1844. Podalirius typicus, Kröyer, Naturh. Tidsskr. 2 R., 1 B. p. 283.

1868. Caprella typica, Bate and Westw., op. cit., vol, ii. p. 75.

Habitat.-Firth of Forth, frequent on the common starfish Asterias rubens, with which it appears to be associated.

Genus (84) Caprella, Lamarck, 1818.

142. Caprella linearis (Linné).

1767. Cancer linearis, Linn., Syst. Nat., ed. xii., vol. ii. p. 1056.

1842. Caprella lcevis, Goodsir, Edin. New Phil. Jour., vol. xxxiii. p. 189 , pl. iii. fig. 4 .

Habitat.- "Plentiful in the laminarian zone" (Henderson). 
South Bay, frequent, 1888. Dredged at Station III. on 23rd May 1901.

\section{Caprella acanthifera, Leach.}

1814. Caprella acanthifera, Leach, Edin. Encyclop., vol. vii. p. 404.

Habitat.-Firth of Forth, taken by the Rev. J. Gordon (cf. Bate and Westwood, Brit. Sessile-eyed Crust., vol. ii. p. 67). A single specimen in my collection has on the label, "Firth of Forth, 1888," but I don't remember what part of the estuary it was taken in.

\section{Caprella tuberculata, Guerin.}

1829. Caprella tuberculata, Guerin, Iconograph. Crust., pl. xxviii. fig. 1.

1842. ", ", Goodsir, op. cit., vol. xxxiii. p. 188, pl. iii. fig. 6.

1869. , , Bate and Westw., Brit. Sessile-eyed Crust., vol. ii. p. 68.

Habitat.-Firth of Forth (Goodsir; specimen in Brit. Mus. Coll. Cf. Bate and Westw., op. cit., p. 70).

\section{Caprella oequilibra, Say.}

1818. Caprella oequilibra, Say, Jour. Acad. Nat. Sci. Philadelphia, vol. i. p. 391.

1899. , , T. Scott, Ann. Scot. Nat. Hist. (April 1899), p. 116.

Habitat.-A considerable number of specimens were obtained amongst Algæ and barnacles scraped from a ship's bottom at Granton Harbour; most of the specimens were either females or immature, but a few adult males were found, by means of which the species to which they belonged was satisfactorily identified.

\section{Sub-Class II. ENTOMOSTRACA}

\section{Order 3. BRANCHIOPODA.}

\section{Suborder Cladocera.}

The arrangement followed for this suborder is that of Professor Lilljeborg's monograph, Cladocera-Suecia, published 
in 1900 (700 pp., and 87 plates). See also the Rev. T. R. R. Stebbing, F.R.S., on "Lynceus and the Lynceidæ," in The Zoologist, March 1902, pp. 101-106.

\section{Suborder Cladocera.}

Division CALYPTOMERA, G. O. Sars.

Tribe Ctenopoda, G. O. Sars, 1865.

Family S I D I $Æ$, Baird, 1850.

Genus (1) Sida, Strauss, 1820.

1. Sida crystallina (O. F. Müller).

1776. Daphne crystallina, Müller, Zool. Dan. Prod., p. 200, No. 2405.

1820. Sida crystallina, Strauss, Mém. Mus. Hist. Nat., vol. vi. p. 157.

Habitat.-Raith Lake, Kirkcaldy, Fifeshire, common, 1890 ; Loch Leven, Kinross; Loch Vennachar and Loch Katrine, Perthshire.

Genus (2) Diaphanosoma, Fischer, 1890.

2. Diaphanosoma brachyurum (Liéven).

1848. Sida brachyura, Liéven, Neueste Schrift. d. Naturf. Gesellschaft in Danzig, 4 : ten Bds. 2 : tes Heft. p. 20, pl. iv. figs. 3-9.

Habitat.-Loch Leven, 1890 ; Raith Lake, 1890, common ; Loch Katrine, Loch Achray, Loch Vennachar; Marfield Loch, Midlothian, September 1901 (Dr and Miss Sprague).

Genus (3) Latona, Strauss, 1820.

3. Latona setifera (O. F. Müller).

1785. Daphnia setifera, Müll., Entomostraca, p. 98, pl. xiv. figs. 5-7.

Habitat.-Loch Lubnaig, 29th September 1894.

${ }^{1}$ For other synonyms see Professor Lilljeborg's work mentioned ahove. 
Family H O L O P E D I D E.

Genus (4) Holopedium, Zaddach, 1855.

4. Holopedium gibberum, Zaddach.

1855. Holopedium gibberum, Zaddach, Wiegmann, Archiv. fur Naturges., Bd. 21, p. 159, pl. viii, fig. 9.

Habitat.-Loch Achray, Loch Voil. Common in Loch Achray in September 1897 and June 1898, but entirely absent during the intervening winter months.

Tribe Anomopoda, G. O. Sars.

Family D A P H I A D $\mathbb{E}$, Strauss.

Genus (5) Daphnia, O. F. Müller, 1785.

The study of the various forms comprised in the genus Daphnia is extremely interesting, but very perplexing. The variations, especially in form, and also to some extent in structural details, are so great that the student of sanguine temperament could easily describe a dozen species where the severely critical could only make out two or three. As I cannot lay claim to a very expert knowledge of the relationships of this difficult genus, it is necessary for me to rely, to some extent, on the discrimination of writers more familiar with it.

\section{Daphnia pulex (De Geer).}

1778. Monoculus pulex, De Geer, Mem. pour. servir a l'hist. nat, des Insectes, T. vii. p. 442, pl. 27 , figs. 1-8.

Habitat.-Generally distributed, and occurring sometimes in considerable abundance. Very plentiful in an artificial pond in the vicinity of Edinburgh in July 1898. ${ }^{1}$ The variety hamata (Brady) has been taken by Dr and Miss Sprague in Granton Quarry, near Edinburgh, and I have found it, as well as the variety obtusata, in the "marl-pit" near Davidson's Mains, Midlothian. This species possesses a comb-like fringe of minute hairs at the base of the postabdominal claw.

${ }^{1}$ Seventeenth Fishery Board Report, part iii. (1899) p. 199.

VOL. XVI. 
6. Daphnia longispina, O. F. Müller.

1785. Daphnia longispina, O. F. Müller, Entomostraca, p. 88, tab. 12, figs. 8-10.

1850. Daphnia pulex, var. longispina, Baird, Brit. Entom., p. 91, pl. vii. figs. 3,4 .

Habitat.-Duddingston Loch (?). A form very common in Duddingston Loch appears to belong to this species. The same form is also common in Loch Leven, and in several other small lakes and ponds. D. longispina differs from the last in the post-abdominal claw being without a pectinate fringe of small hairs at the base. The shell is also usually furnished with a moderately long and slender posterior spine. There appear to be several varieties of $D$. longispinc. A variety with a curious sloping head (var. nasuta, G. O. Sars) was found in Loch Doon in Ayrshire. Immature individuals are sometimes furnished with a "vertex tooth" (cf. var. hamata).

7. Daphnia hyalina, Leydig, var. pellucida, P. E. Müller.

Habitat.-Duddingston Loch (G. S. Brady). This may turn out to be only another form of $D$. longispina, O. F. Muiller.

8. Daphnia lacustris, G. O. Sars.

1862. Daphnia lacustris, G. O. Sars, Om de i Omegnen af Christiania forekommen de Cladocerer, Forhandl. Vidensk. Selsk. Christ. (1861), p. 19.

1899. , " , T. Scott, Seventeenth F. B. Rept., pt. iii. pp. 192-194, pl. vii. figs. 29-33, 34 and $34 \alpha$.

Habitat.-Loch Leven (G. S. Brady). Probably frequent. Hurley Cove, Penicuik, 31st December 1900, common (Dr and Miss Sprague). This species possesses when young, and sometimes also in the adult stage, a "vertex tooth," which may be single or double. D. lacustris is, by some writers, considered to be a variety of the last species ( $D$. hyalina), to which it bears a close resemblance.

9. Daphnia galeata, G. O. Sars.

1863. Daphnia galeata, G. O. Sars, Om en i Somm. 1862 fortagen Zool. Reise i Christ. og Throndh. stifter, p. 21.

1899. Daphnia galeata, T. Scott, Seventeenth F. B. Rept, pt. iii. p. 193 , pl. vii. figs. 22,53 , see also fig. 16 .

Habitat.-Loch Katrine, Loch Achray, and Loch Vennachar. 
Granton Quarry, 1st September 1900 (Dr and Miss Sprague). I find this species exceedingly variable, especially in the form of the head, which in the more typical specimens is strongly crested, but passing by minute gradations to others that have no crest at all, but having the head evenly rounded. I am inclined to agree with those who regard this Daphnia and the two immediately preceding as forms of one and the same species, to which Daphnia jardinii, Baird, must also be ascribed. In that case, Baird's name, being the older, would take precedence of the others.

Genus (6) Scapholeberis, Schoedler, 1858.

10. Scapholeberis mucronata (O. F. Müller).

1785. Daphne mucronata, O. F. Müller, Entomostraca, p. 94, pl, xiii. figs. 6,7 .

Habitat.-Raith Lake, Kirkcaldy, frequent, 1890; Ravelston Cottage Quarry, Midlothian, July 1900 (Dr and Miss Sprague).

Genus (7) Simosa, Norman, 1903.

(Syn._Simocephalus, Schoedler, 1858, preoccupied.)

11. Simosa vetula (O. F. Müller).

1776. Daphne vetula, O. F. Müller, Zool. Dan. Prod., p. 199, No. 2399.

1858. Simocephalus vetulus, E. Schoedler, Jahresber. über die Louisenstädtische Realschule, p. 18.

Habitat.-Duddingston Loch; Loch Leven; Lochgelly and Kilconquhar Lochs, Fifeshire; Loch Coulter, Stirlingshire, etc.; frequent and generally distributed.

Genus (8) Ceriodaphnia, Dana, 1853.

12. Ceriodaphnia reticulata (Jurine).

1820. Monoculus reticulatus, Jurine, Nat. Hist. des Monoc., p. 139, taf. 14, figs. 3,4 .

Habitat.-Raith Lake, Kirkcaldy, frequent, 1890. Upper Elf Loch, Edinburgh, 1896 and 1897. In the same loch in September 1900 by Dr and Miss Sprague. 
13. Ceriodaphnia quadrangula (O. F. Müller).

1785. Daphnia quadrangula, O. F. Müller, Entomostraca, p. 90, tab. 13, fig. 4.

Habitat.-Duddingston Loch, September 1897 and 1898. Taken in the same loch in June 1901 by Dr and Miss Sprague.

14. Ceriodaphnia affinis, Lilljeborg. 1900. Ceriodaphnix affnis, Lillj., Cladocera-Sueciæ, p. 202, tab. 28, figs. 19-28.

1901. „, scitula, Herrick? (Sprague), Trans. Edin. Field Nat. and,Micros. Soc., vol. iv. pt. iii. p. 258. 1902. ", affinis, Sprague, op. cit., pt. iv. pl. xxxA. figs. 1.4 .

Habitat.-High Pond, Penicuik, 7th September 1901 (Dr and Miss Sprague).

This rare species is one of the additions made to the Entomostracan fauna of the inland waters of Scotland by Dr and Miss Beatrice Sprague.

15. Ceriodaphnia laticaudata, P. E. Müller.

1867. Ceriodaphnia laticaudata, P. E. Müller, Danmarks Cladocera, p. 130 , pl. i. fig. 19.

Habitat.-Duddingston Loch, September 1897, frequent; not observed in 1898.

Family B o S M I A D $Æ$.

Genus (9) Bosmina, Baird, 1850.

16. Bosmina longirostris (O. F. Müller).

1776. Lynceus longirostris, O. F. Müller, Zool. Dan. Prod., No. 2394. 1846. Bosmina longirostris, Baird, Ann. and Mag. Nat. Hist., vol. xvii. p. 412.

Habitat.-Common and generally distributed in small lakes and ponds throughout the lowland parts of the district.

17. Bosmina longispina, Leydig.

1860. Bosmina longispina, Leydig, Naturgesch. d. Daphniden, p. 207, pl. viii. fig. 62 .

Habitat.-Loch Katrine, Loch Achray, Loch Leven, etc.; 
not rare in the larger lakes, where both species are sometimes found living together. They are both variable species, and a number of varieties have been described.

Family Ly N C D A P H I D $Æ$, G. O. Sars.

Genus (10) Ilyocryptus, G. O. Sars, 1861.

18. Ilyocryptus sordidus (Liévin).

1848. Acanthocercus sordidus, Liévin, Die Branchiopoden d. Danziger Gegend; Neueste Schrift. d. Naturf. Gesell. in Danzig, 4 : ten Bds. 2 : tes Heft. p. 34, pl. viii. figs. 7-12.

Habitat.-Lochend Loch, Edinburgh, Loch Leven; Linlithgow Loch, and Loch Achray; not uncommon. Úpper Elf Loch, Edinburgh (Dr and Miss Sprague).

\section{Genus (11) Macrothrix, Baird.}

19. Macrothrix laticornis (Jurine).

1820. Monoculus laticornis, Jurine, Hist. des Monocles, p. 151, pl. xv. figs. 6,7 .

1901. Macrothrix laticornis, Dr and Miss Sprague, Trans. Edin. Field Nat. and Micros. Soc., vol. iv. p. 258, pl. xxxA. figs. 13-15.

Habitat.-Pond in Queen's Park, Edinburgh, 16th June 1900; rare (Dr and Miss Sprague).

Genus (12) Lathonura, Lilljeborg, 1853.

20. Lathonura rectirostris, O. F. Müller.

1785. Daphnia rectirostris, O. F. Müller, Entomostraca, etc., p. 92, pl. xii. figs. 1-3.

Habitat.-Loch Achray, Trossachs, November 1897; rare.

Genus (13) Drepanothrix, G. O. Sars, 1861.

21. Drepanothrix dentata (H. A. Eurén).

1861. Acantholeberis dentata, Eurén, Öfvers af K. Wet.-Akad. Forh. (1861), No. 3, p. 118, pl. iii. fig. 2.

Habitat.-Loch Lubnaig, Loch Katrine, and Loch Achray. 
Genus (14) Acantholeberis, Lilljeborg, 1853.

22. Acantholeberis curvirostris (O. F. Müller).

1776. Daphne curvirostris, O. F. Müller, Zool. Dan. Prod., p. 200, No. 2403.

Habitat.-Marfield Loch, Midlothian, 21st September 1901 ; rare (Dr and Miss Sprague).

Family Cну D о в д ж, T. R. R. Stebbing, 1902.

Genus (15) Eurycercus, Baird, 1843.

23. Eurycercus lamellatus (O. F. Müller).

1785. Lynceus lameliatus, O. F. Müller, Entomostraca, p. 73, pl. ix. figs. 4-6.

Habitat.-Common and generally distributed throughout the district.

Genus (16) Camptocercus, Baird, 1843.

24. Camptocercus rectirostris, Schoedler.

1862. Camptocercus rectirostris, Schoedler, idem, Die Lynceiden u. Polyphemiden der Umgegend v. Berlin, Ichresb. ü. d. Dorothunstäd Realschule, p. 25, pl. ii. fig. 43.

Habitat.-Loch Achray, November 1897 ; rare. The form described in Baird's classical work on British Entomostraca is probably this species. Typical specimens of $C$. macrurus (O. F. Müller) have been observed in none of the Scottish lakes or ponds examined by me.

Genus (17) Acroperus, Baird, 1843.

25. Acroperus harpae, Baird.

1835. Lynceus harpae, Baird, Trans. Berw. Nat. Club, vol. i. p. 100 , pl. ii. fig. 17 .

1850. Acroperus harpae, idem, Brit. Entom., p. 129, pl. xvi. fig. 5.

Habitat.-Generally distributed and moderately common throughout the district.

Genus (18) Alonopsis, G. O. Sars, 1862.

26. Alonopsis elongata, G. O. Sars.

1862. Alonopsis elongata, G. O. Sars, Forh. i Vidensk. Selsk. i Christiania, 1861 (Aftr.), p. 53.

Habitat.-Moderately common in several of the larger 
lakes throughout the district. I have no record of it from the loch at Duddingston or from any locality in the vicinity of Edinburgh except Marfield Loch, where it was obtained by Dr and Miss Sprague, and in the Union Canal by myself.

Genus (19) Alona, Baird, 1843.

27. Alona quadrangularis (O. F. Müller).

1776. Lynceus quadrangutaris, O. F. Müller, Zool. Dan. Prodr., p. 199, No. 2393.

1895. Alona costata, T. Scott, Thirteenth F. B. Rept., pt. iii. p. 189, pl. v. figs. 2 and 12.

Habitat.-Loch Achray, Loch Leven, Duddingston Loch, etc. This species appears to be generally distributed and moderately frequent throughout the district.

28. Alona affinis, Leydig.

1860. Alona affinis, Leydig, Naturgesch. d. Daphniden, p. 223, pl. ix. figs. 68,69 .

1895. ", quadrangularis, T. Scott, loc. cit., p. 1895, pl. v. figs. 2, 11, 13, 15, and 25 .

Habitat.-Distribution somewhat similar to that of $A$. quadrangularis.

29. Alona tenuicaudis, G. O. Sars.

1862. Alona tenuicaudis, G. O. Sars, loc. cit., p. 37.

Habitat.-Camilla Loch, Fifeshire, 1894, not uncommon; Duddingston Loch, frequent, 1st September 1897, but when this loch was visited three months later the species was not so common. No specimens were observed on 2nd March, but it was again of frequent occurrence in a shore-gathering collected on 15th June 1898. Dr and Miss Sprague found A. tenuicaudis rare in Duddingston Loch on 18th August 1900 .

30. Alona costata, G. O. Sars. 1862. Alona costata, G. O. Sars, loc. cit., p. 38.

Habitat.-Upper Elf Loch, and ditch near Harelaw Dam, 
in the vicinity of Edinburgh; Lochgelly Loch; not uncommon.

31. Alona guttata, G. O. Sars.

1862. Alona guttcata, G. O. Sars, loc. cit., p. 39.

1895. ", , T. Scott, Thirteenth F. B. Rept, pt. iii. p. 190, pl, v. figs. 6 and 16 .

Habitat.-Camilla Loch, Loch Leven, Loch Achray, and Upper Elf Loch. Duddingston Loch (Dr and Miss Sprague).

32. Alona intermedia, G. O. Sars.

1862. Alona intermedia, G. O. Sars, loc. cit., p. 38.

${ }^{1}$ 1895. ,, neglecta, T. Scott, Thirteenth F. B. Rept., pt. iii. p. 189, pl. v. figs. 4 and 18.

Habitat.-Loch Katrine and Loch Achray. This species, which does not appear to be very rare, was described in 1895 from specimens found in some Shetland lochs. It has not yet been recorded from England or Ireland.

33. Alona rustica, T. Scott.

1895. Alona rustica, T. Scott, Thirteenth F. B. Rept., pt. iii. p. 189, pl. v. figs. 5 and 17 .

Habitat.-Loch Achray. This appears to be a widely distributed though somewhat local species. It was first observed in samples of Entomostraca sent to me from Shetland by Robert Duthie, Fishery Officer.

\section{Alona rostrata (Koch).}

1841. Lynceus rostratus, Koch, Deutschlauds Crustacean, Heft. 36, pl. 12.

1901-1902. Alonella rostrata, Dr and Miss Sprague, Trans. Edin. Field Nat. and Micros. Soc., vol. iv. pp. 259 and 321.

Habitat.-Cobbinshaw Reservoir, 13th August 1900; rare (Dr and Miss Sprague).

1 The Alona intermedia recorded from Shetland in the Thirteenth F. B. Report is not Sars' species of that name, but the Alonce rectangula of G. O. Sars. I have no record for this species from the Forth basin, but as it is not rare, especially in ponds and marshy places near the sea, it may yet be found in the district. 
Genus (20) Rhynchotalona, Norman, 1903.

(Syn.-Leptorhynchus, Herrick, and Harporhynchus, G. O. Sars, both of which names are preoccupied.)

35. Rhynchotalona falcata (G. O. Sars).

1861. Alona falcata, G. O. Sars, Forhandl. i Vidensk, i Christiania, 1861 (Aftr.), p. 20.

Habitat.-Loch Katrine and Loch Achray; not common.

\section{Genus (21) Ledigia, Kurz.}

36. Ledigia quadrangularis (Leydig).

1860. Lynceus quadrangularis, Leydig, Naturges. der Daphnid., p. 221, pl. viii. fig. 59 .

1891. Ledigia quadrangularis, T. Scott, Ninth F. B. Rept., pt. iii. p. 292, pl. vi. figs. 5, 5a and $b$.

Habitat.-Lochgelly Loch, Fifeshire. It may be of interest to recall the fact that the record of this species in the Fishery Board's Report mentioned above was the first for Britain.

Genus (22) Graptoleberis, G. O. Sars, 1862.

37. Graptoleberis testudinarius (Fischer).

1851. Lynceus testudinarius, Fischer, Mem. des Sar étrangers, St Petersburg, vol. vi. p. 191, pl. ix. fig. 12.

Habitat.-Lochend Loch, 1894; Upper Elf Loch, Braid Hills, 1896 and 1897, where it was also obtained in August 1901 by Dr and Miss Sprague.

Genus (23) Alonella, G. O. Sars, 1862.

38. Alonella excisa (Fischer).

1854. Lynceus excisus, Fischer, Bull. Soc. Impér. d. Nat. d. Moscow (1854), p. 428, pl. iii. figs. 11-14.

Habitat.-Loch Leven, frequent. Loch Katrine, Loch Achray, Loch Vennachar, and Loch Lubnaig. Marfield Loch, 
9th April 1901 (Dr and Miss Sprague). As Alonella excisa (Fischer) and $A$. exigua (Lilljeborg) are retained by Lilljeborg as distinct species, and as the Scottish specimens I have examined belong to Fischer's $L$. excisus, that name is used here (see remarks in Seventeenth F. B. Rept., pt. iii. p. 201).

39. Alonella nana (Baird).

1843. Acroperus nanus, Baird, Ann. and Mag. Nat. Hist., vol, ii. p. 92 , pl. iii. fig. 8 .

Habitat.-Upper Elf Loch, Raith Lake, Loch Leven, Loch Katrine, Loch Achray. Marfield Loch (Dr and Miss Sprague).

Genus (24) Peratacantha, Baird, 1843.

40. Peratacantha truncata, O. F. Müller.

1785. Lynceus truncatus, Muiller, Entomostraca, p. 75, pl. xi. figs. 4-8.

Habitat.-Lochgelly Loch, Loch Katrine, Loch Achray, Loch Vennachar, and Loch Lubnaig. High Pond, Penicuik, 7th September 1901; rare (Dr and Miss Sprague).

Genus (25) Pleuroxus, Baird, 1843.

41. Pleuroxus loevis, G. O. Sars.

1861. Pleuroxus loevis, G. O. Sars, Forh. i Vid. Selsk. i Christiania, 1861 (Aftr.), p. 22.

Habitat.-Camilla Loch, Fifeshire; not common.

42. Pleuroxus trigonellus (O. F. Müller).

1785. Lynceustrigonellus, Müll., Entomostraca, p. 74, pl. x. figs. 5, 6 .

Habitat.-Duddingston Loch, Loch Leven, Raith Lake, Loch Katrine, Loch Achray. Marfield Loch (Dr and Miss Sprague).

43. Pleuroxus uncinatus, Baird.

1850. Pleuroxus uncinatus, Baird, Brit. Entomostraca, p. 135, pl. xvii. fig. 4.

Habitat.-Raith Lake and Loch Leven. 
Genus (26) Chydorus, Leach, 1816.

44. Chydorus globosus, Baird.

1850. Chydorus globosus, Baird, Brit. Entomostraca, p. 127, pl. xvi. fig. 7.

Habitat.-Loch Achray, Dr and Miss Sprague collected this fine species in an old quarry in Dalmeny grounds, close to the river Almond, on 6th September 1901.

45. Chydorus ovalis, Kurz.

1874. Chydorus ovalis, Kurz, Dodekas neuer Cladoc., p. 73, pl. iii. fig. 11.

Habitat.-A few specimens of a Chydorus, which agree with the description of $C$. ovalis given by Professor Lilljeborg in his important work on the Swedish Cladocera, were obtained in Linlithgow Loch in October 1896 and in Loch Leven in June 1898.

46. Chydorus latus, G. O. Sars.

1862. Chydorus latus, G. O. Sars, Vid. Selsk. i Christiania Forh., 1861 (Aftr.), p. 41.

Habitat.-Loch Achray, frequent in March 1898, but this was the only time it was observed during my four visits to this loch.

47. Chydorus barbatus (G. S. Brady).

1868. Lynceus barbatus, Brady, Intellectual Observer, 1868.

Habitat.-This Chydorus appears to be moderately frequent in some of the lochs and ponds within the district under consideration, as Loch Leven, Loch Lubnaig, Loch Katrine, Loch Achray, etc. As remarked by Mr Scourfield, "the ventral shell margin is in this species densely fringed with long plumose setæ, hence the name $C$. barbatus."

48. Chydorus sphoricus (O. F. Müller).

1785. Lynceus sphcericus, O. F. Müller, Entomostraca, p. 71, No. 2932.

Habitat.-Common and generally distributed. C. coelatus, Schoedler, is, according to Professor Lilljeborg, a variety of C. sphcericus. 
Genus (27) Monospilus, G. O. Sars, 1861.

49. Monospilus dispar, G. O. Sars.

1861. Monospilus dispar, G. O. Sars, Vid. Selsk. i Christiania Forhandl., 1861, p. 23.

1891. „, tenuirostris (Fischer), T. Scott, Ninth F. B. Rept., pt. iii. pp. 272 and 295 , pl. v. fig. 1.

Habitat.-Loch Leven, 1890; Loch Achray, November 1897 ; rare.

\section{Division GYMNOMERA.}

Tribe Onychopoda, G. O. Sars.

Family P OL Y P H M D

Genus (28) Polyphemus, O. F. Müller, 1776.

50. Polyphemus pediculus, Linné.

1761. Monoculus pediculus, Linn., Fauna Suecica, p. 498, No. 2048.

Habitat.-Loch Leven, 1890; Loch Lubnaig, 1894; Loch Vennachar, Raith Lake.

Genus (29) Bythotrephes, Leydig, 1860.

51. Bythotrephes longimanus, Leydig.

1860. Bythotrephes longimanus, Leydig, Naturges. der Daphuiden, p. 244, pl. x. figs. 73-75.

Habitat.-Loch Leven, 1890; Loch Vennachar (1895), Loch Katrine, and Loch Achray. Not uncommon in the larger lochs.

Genus (30) Podon, Lilljeborg, 1853.

(The members of this genus and the next are marine.)

52. Podon Leuckarti, G. O. Sars.

1862. Pleopis leuckarti, G. O. Sars, Forhandl. i Vidensk. Selsk. i Christiania, 1861, p. 45.

1902. " " $\quad$ T. Scott, Twentieth F. B. Rept., pt. iii. p. 476, pl. xxv. figs. 23 and 24.

Habitat._Firth of Forth, occasionally frequent, especially 
in the seaward part of the estuary. The Podon polyphemoides recorded in Part III. of the Ninth Annual Report of the Fishery Board for Scotland, p. 308 (1891), is probably this species, as no Forth specimens of $P$. polyphemoides are now in my collection.

Genus (31) Evadne, S. Loven, 1836.

53. Evadne Nordmanni, Loven.

1836. Evadne nordmanni, Loven, K. Wetensk.-Akad. Handl., 1835, p. 1, pls. i. and ii. figs. 1-16.

Habitat.-Firth of Forth, usually moderately common.

Tribe Haplopoda, G. O. Sars.

Family LE P T O D O R I $\mathbb{E}$, Lilljeborg.

Genus (32) Leptodora, Lilljeborg, 1861.

54. Leptodora Kindtii (Focke).

1844. Polyphemus kindtii, Focke, Sonntagsplatt. der Weser-Zeitung, No. 34, p. 6.

1861. Leptodora hyalina, Lillj., Öfversigt af K. Vet.-Akad. Förhandl., 1860, No. 5, p. 265, taf. vii. figs. 1.22.

Habitat.-Loch Leven, June 1890, frequent in the open water; common on 3rd September 1897, but no specimens were obtained in December of the same year, nor in the months of March and June of 1898. A few specimens were captured in September 1897 in Loch Katrine, but none in November; in 1898 none were taken in March, while in June, though none were observed at the upper end of the loch, the species was moderately frequent at the lower end. The only other lake within the limits of the district from which I have notes of Leptodora is Loch Achray; it was found sparingly here on 10th September 1897, but no specimens were observed when the loch was visited in November; neither were any specimens observed when the loch was examined on the 17th of March and the 28th of June 1898. 
In Professor Lilljeborg's work on the Cladocera of Sweden, 38 genera are described; 32 of them are represented in the preceding list. The 6 not represented are as follows :-

1. Limnosida, G. O. Sars.

4. Bunops, E. A. Birge.

2. Moina, W. Baird.

5. Streblocerus, G. O. Sars.

3. Ophryoxus, G. O. Sars.

6. Anchistropus, G. O. Sars.

Three of these-Ophryoxus gracilis, G. O. Sars, Streblocerus serricaudatus (Fischer), and Anchistropus emarginatus, G. O. Sars, have been obtained in Scotland. The first was discovered by Mr D. J. Scourfield in Loch Ness, and in a backwater of the Caledonian Canal at Coiltry Lock. The second I found in the Dhu Lochan-a small loch close to Loch Lomond, and about two miles south of Rowardennan. The third was taken by the late Dr Robertson, of Millport, in 1863 , in the Paisley Canal (since filled up), and has occurred more recently in Ireland, and at one or two places in England.

Moina - all three species-has been recorded from England, but not from Scotland, and there does not appear to be any British record for the other two. But though the genera are so well represented, our list comes far short in the matter of species. Lilljeborg describes about 100 species from Sweden, besides numerous varieties, whereas our record amounts only to 54. It is thus apparent that further research is necessary, and will doubtless be rewarded.

\section{Suborder Branchiura.}

Family A RGULID Æ, Leach, 1819.

Genus (1) Argulus, O. F. Müller, 1781.

1. Argulus foliaceus (Linn.).

1785. Monoculus foliacers, Linn., Syst. Nat., ed. x., p. 634, No. 2. 1850. Argulus foliaceus, Baird, Brit. Entom., p. 255, pl. xxxi. figs. $1,2$.

Habitat.-Found attached to a specimen of the Threespined Stickleback (Gasterosteus aculeatus), and also free amongst Anacharis in the Union Canal, near Edinburgh, by Mrs Janet Carphin, on 26th August 1895.1

${ }^{1}$ Ann. Scot. Nat. Hist., No. 16, October 1895, p. 255. 


$$
\text { • }
$$

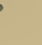



Vol. XVI.

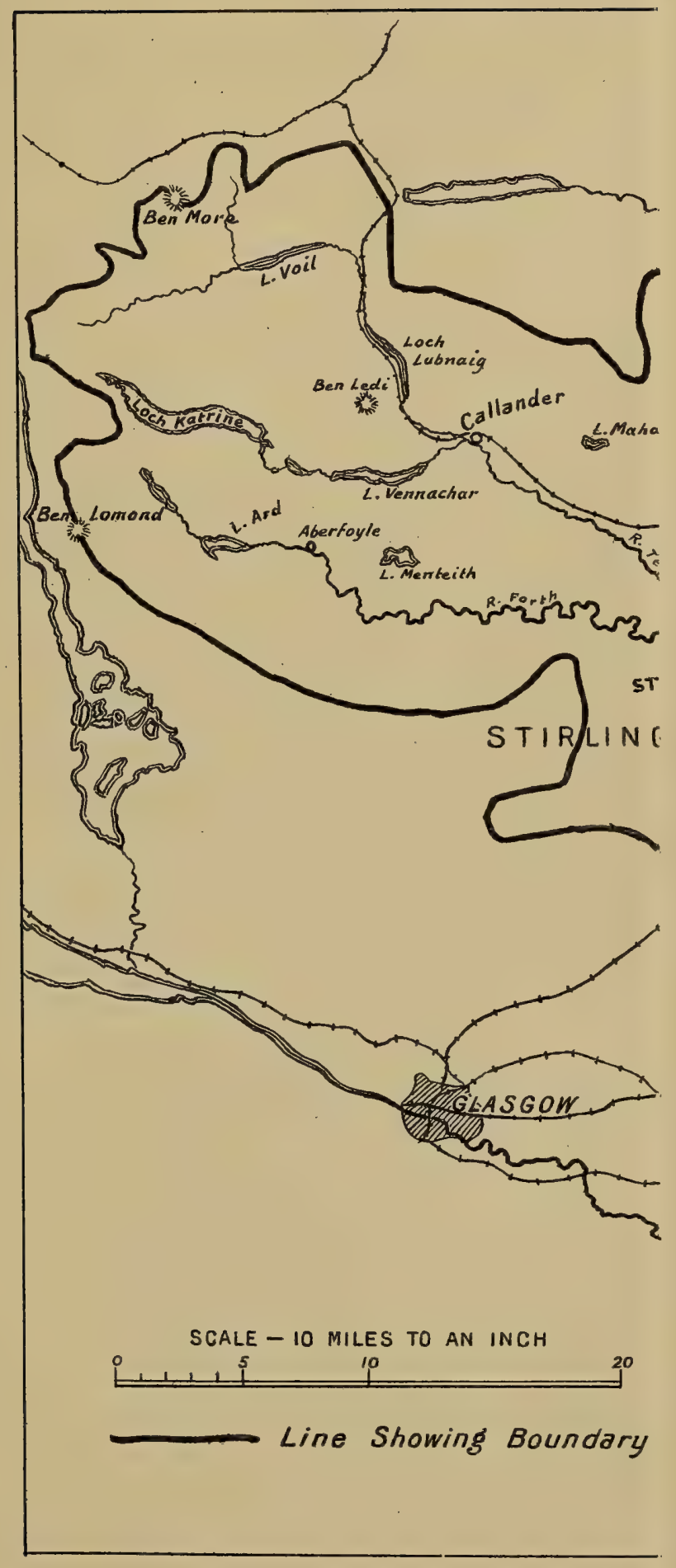

SKETCH-MAP \& 



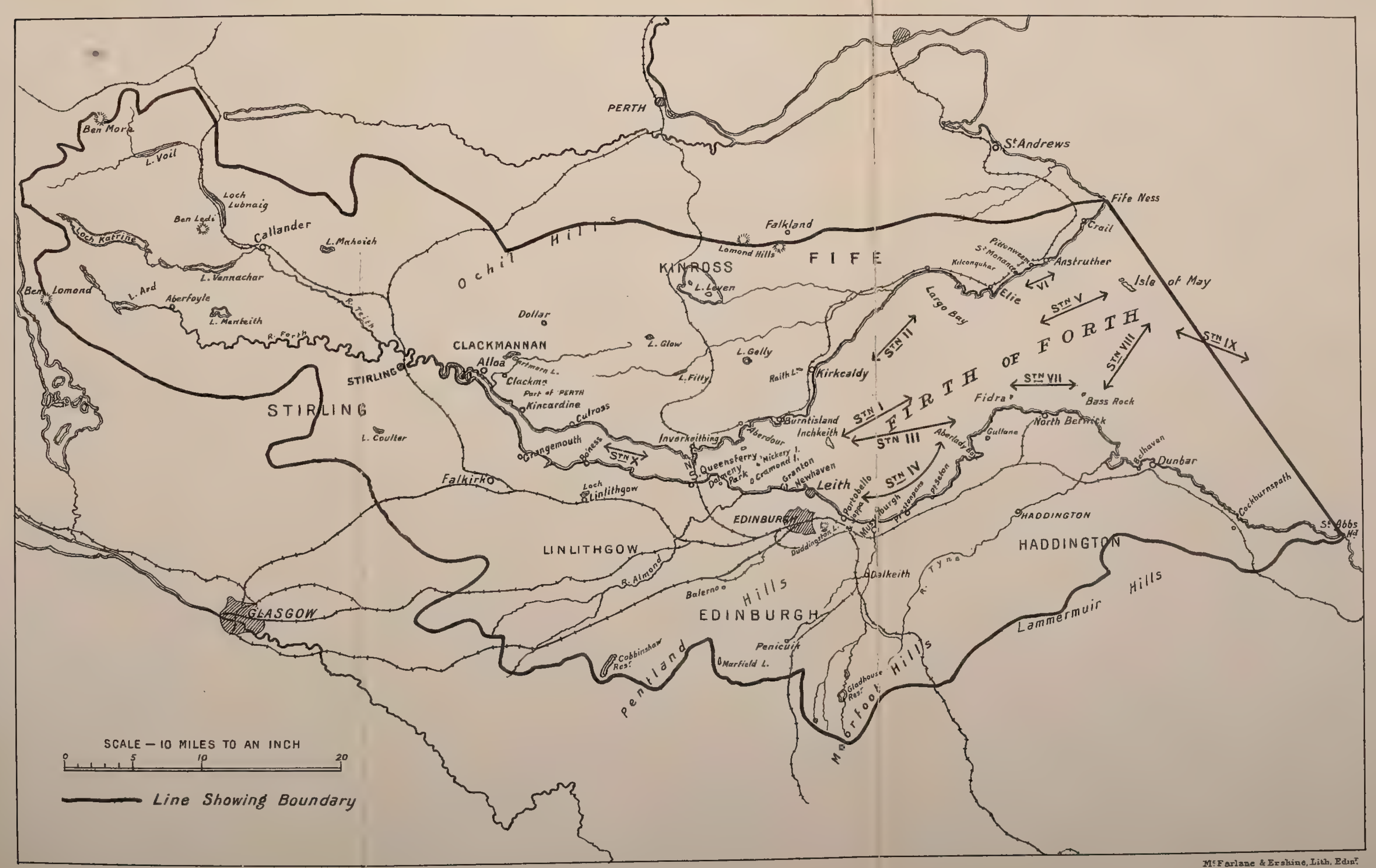

Sketch-Map showing the limits of the Basin of the River forth and its Estuary. 

$\checkmark$ 



\section{PROCEEDINGS}

OF THE

\section{ROYAL PHYSICAL SOCIETY OF EDINBURGH.}

\section{SESSION 1905-1906.}

$$
\text { VOL. XVI-No. } 7 .
$$

\section{A GATALOGUE OF}

\section{LAND, FRESH-WATER, AND MARINE GRUSTACEA FOUND IK} THE BASIN OF THE RIVER FORTH AND ITS ESTUARY.

\section{PART II.}

BY

THOMAS SCOTT, LL.D., F.L.S., Mem. Soc. Zool. de France, etc.

EDINBURGH :

Publishitd by ROBERT GRANT \& SON, 107 Princes Striet. MDC̄CCVI. 

XXIII. A Catalogue of Land, Fresh-Water, and Marine Crustacea found in the Basin of the River Forth and its Estuary. By Thомаs Scotт, LL.D., F.L.S., Mem. Soc. Zool. de France, etc.

(Read 26th March 1906.)

PART II.-THE OSTRACODA, COPEPODA, AND CIRRIPEDIA.

(Part I., published in the Proceedings, Vol. XVI. pp. 97-190, contained the Malacostraca, Cladocera, and BranchiUra.)

\section{Order OSTRACODA.}

The work that has been mainly followed in the arrangement and nomenclature of the Ostracoda is that by Professor G. S. Brady and the Rev. Canon A. M. Norman, entitled "A Monograph of the Marine and Fresh-Water Ostracoda of the North Atlantic and North-Western Europe." The work was published in two separate portions in the scientific Transactions of the Royal Dublin Society. The first portion, which formed Part II. of Vol. IV. (Series 2), appeared in 1889, and the second, which formed Part II. of Vol. V. of the same series, in 1896 .

In this work the Ostracoda are divided into four sections, viz.-(1st) the Podocopa, which comprises all the freshwater and most of the marine species; (2nd) the Myodocopa, which is represented in this Catalogue by only two species, Asterope Marice and Philomedes interpuncta; (3rd) the Cladocopa, which is represented by Polycope orbicularis and Polycopsis compressa; and (4th) the Platycopa-a section not represented in this Catalogue.

As this work has been, with few exceptions, followed throughout, I have not considered it necessary to mention it under every species, and where it is mentioned it is referred to as the Monograph (or l.c.), Part I. or Part II., as the case may be.

Various other works have been consulted, two of which VOL. XVI. 
may be mentioned here, viz., one by Dr G. W. Müller on "The Fresh-Water Ostracoda of Germany," and the other by Dr A. Kaufmann on "The Fresh-Water Ostracoda of Switzerland."

Section I. Podocopa.

Family C Y P R I D I D

Genus (1) Cypria, Zenker, 1854.

1. Cypria exculpta (S. Fischer).

1855. Cypris exculpta, Fischer, Beitrag zur Kenntniss der Ostracoden, Abhdlg. der math.-phys. Klasse der k. bayr. Akad. d. Wiss., Bd. vii. p. 652, taf. xix. figs. 36-38.

This species, though widely distributed, is not very common in the district under consideration. It has been obtained in Loch Leven, ${ }^{1}$ Lochgelly Loch, Lochs Lurg and Dow, Kinross; Loch Achray, Perthshire; and Goldenhoof Dam, near Howietoun, Stirlingshire. Loch Ard, July 1906 (W. Evans).

2. Cypria ophthalmica (Jurine).

1820. Monoculus ophthalmicus, Jurine, Hist. des Monocles, p. 178, taf. xix. figs. $16,17$.

This is one of the most common and widely distributed species of our fresh-water Ostracoda.

Genus (2) Cyclocypris, G. S. Brady and A. M. Norman, 1889.

3. Cyclocypris globosa (G. O. Sars).

1863. Cypris globosa, G. O. Sars, Om en i Somm., 1862, foretagen Zool. Reise i Christianias og Trondhjems Stifter, p. 27.

Has been obtained in a pond near Musselburgh in August 1894; Loch Leven, Loch Fitty, Black Loch, Loch Dow, Loch Katrine, Loch Achray, Loch Vennachar, and Loch Coulter. Teith at Callander (Evans).

${ }^{1}$ It will be understood that the Loch Leven mentioned in this Catalogue is Loch Leven, Kinross. 
4. Cyclocypris serena (Koch).

1838. Cypris serena, Koch, Deutschlands Crustaceen, Heft xxi. p. 22.

1896. Cyclocypris serena, B. and N., l. c., Part II. (Appendix) p. 718.

A common and widely distributed species. It has been found in Loch a Chroin, at an altitude of 2500 feet, by $\mathrm{Mr}$ Evans.

5. Cyclocypris locvis (O. F. Müller).

1896. Cyclocypris loevis, Brady and Norman, l.c., Part II. (Appendix) p. 718.

This, which is not such a common species as the last, has an elliptical instead of an ovate form when looked at from above. It has been observed in Duddingston Loch, Lochgelly Loch, pools on Luffness Links, etc.

Dr G. W. Müller appears to think that the species referred by G. S. Brady and Norman to Cyclocypris serena, Koch, is the true $C$. loevis of O. F. Müller, and that their C. lcevis is probably identical with a form described by Croneberg under the name of Cyclocypris pygmoea. ${ }^{1}$

Genus (3) Cypris, O. F. Müller, 1785.

6. Cypris fuscata, Jurine.

1820. Cypris fuscata, Jurine, Hist. des Monocles de Geneva, p. 174, pl. xix. figs. 1-16.

Hab.-Duddingston Loch; Upper Elf Loch, Braid Hills; Linlithgow Loch; Loch Leven. Roslin Curling Pond, March 1906 (W. Evans).

7. Cypris incongruens, Ramdohr.

1806. Cypris incongruens, Ramdohr, Mag. der Gesells. naturf. Freunde in Berlin, Bd. ii. p. 86, taf. iii. figs. 1-12 et. seq.

Hab.-Abundant in pools in the brickfield at Portobello in the autumn of 1888. In pools on May Island in September 1890. Common in pools on the side of the Union Canal at

${ }^{1}$ Scottia Browniana (Jones), which up till 1887, when living specimens were obtained near Rothesay, was only known as a fossil, was collected in a post-Tertiary deposit at Elie, Fifeshire, by the late James Bennie of the Geological Survey (cf. Proc. Roy. Phys. Soc. Edin., vol. x. pp. 339-341, 1890-91). This form, which is placed between Cyclocypris and Cypris, has not yet been found living on the east side of Scotland. 
Kingsknowe in May 1888. Pond at House-o'-Hill Farm, Midlothian, common, July 1900 (Dr and Miss Sprague).

8. Cypris virens, Jurine.

1820. Cypris virens, Jurine, Hist. des Monocles, p. 174, taf. xviii. figs. $15,16$.

Hah._Duddingston Loch; pools on Luffness Links; pools at Slateford; Kilconquhar Loch; Loch Leven. Marchfield Pond, July 1900, very common (Dr and Miss Sprague). Roslin Curling Pond, March 1906 (Evans).

9. Cypris affinis, Fischer.

1851. Cypris affinis, Fischer, Ueber das genus Cypris, p. 32, pl. x. figs. 9-11.

1889. " reticulata, Brady and Norman, l. c., Part I. p. 76, pl. viii. figs. 1,2 ; pl. xi. figs. 5-7.

1900 " affinis, Kaufmann, Cypriden u. Darwinuliden der Schweiz, Revue Suisse de Zool., T. 8, p. 272, taf. xv. figs. 17-20 et seq.

Hab.-Camilla Loch, Fifeshire, and Duddingston Loch. This species does not appear to be very common. (I have recorded C. affinis from Linlithgow Loch, but the dissections show that the specimens belong to C. fuscata.)

10. Cypris obliqua, G. S. Brady.

1868. Cypris obliqua, Brady, Mon. rec. Brit. Ostrac., p. 364 , pl. xxiii. figs. $33-38$.

Hab._Lurg Loch (near L. Glow), Kinross-shire; Lochgelly Loch and Loch Achray. Craigleith Quarry, near Edinburgh, February 1901, one specimen (Dr and Miss Sprague).

Genus (4) Eurycypris, G. W. Müller, 1898.

11. Eurycypris pubera (O. F. Müller).

1785. Cypris pubera, O. F. Müller, Entomostraca, p. 56, taf. v. figs. 1-5.

1900. Eurycypris pubera, G. W. Müller, Deutschl. Süssw.-Ostrac., p. 54, taf. xiii. figs. 1-11.

Hab.-Duddingston Loch (Baird, Norman, and myself); Kilconquhar Loch; Kinghorn Loch (common); Lochgelly 
Loch. Townhill Loch, Dunfermline (D. Robertson). Otterston Loch, Fife, October 1905 (W. Evans).

Genus (5) Cyprinotus, G. S. Brady, 1886.

12. Cyprinotus prasina (Fischer).

1889. Cypris prasina, Brady and Norman, Monograph, Part I. p. 78.

1896. Cyprinotus prasina, id., Part II. (Appendix) p. 772.

Hab.-Pools in an old brickfield at Seafield, near Dunbar, August 1890 ; in pools at the mouth of the Peffer Burn, near Aberlady, August 1893. Cyprinotus prasinus was obtained by the late James Bennie, of the Geological Survey, in material excavated from the bed of the Old "Nor Loch," Edinburgh (cf. Proc. Roy. Phys. Soc. Edin., vol. x. p. 139, 1889).

Geuus (6) Herpetocypris, G. S. Brady and A. M. Norman, 1896.

Erpetocypris, idem, 1889.

13. Herpetocypris reptans (Baird).

1835. Candona reptans, Baird, Trans. Berw. Nat. Club, vol. i. p. 99, pl. iii. fig. 11.

Hab.-Duddingston Loch, Loch Leven, Linlithgow Loch, Loch Lubnaig, pools on Gullane Links, and various other places throughout the district. Loch Ard (Evans).

14. Herpetocypris strigata (O. F. Müller).

1785. Cypris strigata, O. F. Müller, Entomostraca, p. 54, pl. iv. figs. 4-6.

Hab.-Duddingston Loch, Loch Leven, Black Loch near L. Glow; pools at Kingsknowe near Edinburgh, May 1888; Loch Coulter; and about Howietoun, Stirlingshire, 1889.

15. Herpetocypris tumefacta, G. S. Brady and D. Robertson. 1870. Cypris tumefacta, B. and R., Ann. and Mag. Nat. Hist. (4), vol. vi. p. 13, pl. iv. figs. 4-16.

Hab.-Duddingston Loch, Loch Leven, pools on Luffness Links, Loch Achray, Loch Vennachar, Loch Coulter, and pools near Howietoun, etc. Ben Ledi, at 2500 feet (Evans). 
Genus .(7) Ilyodromus, G. O. Sars, 1894.

16. Ilyodromus olivacea (G. S. Brady and A. M. Norman).

1889. Erpetocypris olivacea, B. and N., l. c., Part I. p. 89, pl. viii. figs. 3,4 .

1896. Ilyodromus olivacea, l. c., Part II. (Appendix) p. 724.

Hab.-Duddingston Loch, Kinghorn Loch, Black Loch near L. Glow.

17. Ilyodromus Robertsoni, G. S. Brady and A. M. Norman. 1889. Erpetocypris Robertsoni, B. and N., l. c., Part I. p. 88 (with two text figures).

1896. Ilyodromus Robertsoni, l. c., Part II. (Appendix) p. 724.

Hab.-Linlithgow Loch; Black Loch near L. Glow, 14th September 1889.

Genus (8) Cypridopsis, G. S. Brady, 1867.

18. Cypridopsis villosa (Jurine).

1820. Monoculus villosus, Jurine, Hist. des Monocles, p. 178, pl. xix. figs. 14, 15.

1868. Cypridopsis villosa, Brady, Mon. rec. Brit. Ostrac., 1. 377, pl. xxiv. figs. 11-15; pl. xxxvi. fig. 9.

Hab.-Duddingston Loch, Loch Leven, and in various other lochs and ponds throughout the district

19. Cypridopsis aculeata (Lilljeborg).

1853. Cypris aculeata, Lillj., De Crust. ex Ord. trib., p. 117, taf. xi. figs. $15,16$.

1868. Cypridopsis aculeata, Brady, l.c., p. 376, pl. xxiv. figs. 16-20; pl. xxxvi. fig. 10.

Hab.-Pools in an old brickfield at Seafield, near Dunbar; Gullane, near Aberlady, August 1893. Cramond Island, July 1901 (Dr and Miss Sprague).

Genus (9) Pionocypris, G. S. Brady and A. M. Norman, 1896.

20. Pionocypris vidua (O. F. Müller).

1785. Cypris vidua, O. F. Müller, Entomostraca, p. 55, taf. iv. figs. 7-9.

1889. Cypridopsis vidua, B. and N., l.c., Part I. p. 89.

1896. Pionocypris vidua, id., ibid., Part II. (Appendix) p. 726.

Hab.-Duddingston Loch, Loch Leven, Loch Coulter, Loch 
Achray; Loch Rusky (Evans); and generally throughout the district, especially in the smaller bodies of water.

Objection is taken to the separation of this species from the genus Cypridopsis, to which it was ascribed by Dr G. S. Brady in 1867, but, as pointed out by Brady and Norman in the Appendix to their valuable Monograph, pp. 725 and 726 , its removal became necessary when it was found to differ materially in the principal character on which the genus was founded, viz., the caudal rami. These were described as "being quite rudimentary, consisting of two slender setiform processes springing from a common base." Careful examination has shown that while C. villosa, C. aculeata, and one or two others agree so far with this definition, the caudal rami in C. vidud consists of four setiform processes, and also that the basal part of each pair of processes differs to some extent. Dr Kaufmann does not appear to attach much value to this difference, and therefore replaces $C$. vidud under Cypridopsis, but he at the same time removes the others to a new genus-Cypridopsella - the chief distinguishing character of which is that while the first has five the other has only two hairs on the branchial plate of the first maxilla. ${ }^{1}$ Though $C$. viduc was made the type of the genus Cypridopsis by Dr Brady, it was doubtless because he considered its furca to be similar to that of the two species associated with it, and as these two species agree with the definition of Cypridopsis, I think they ought to be retained in that genus, and C. vidua removed, as has been done by Brady and Norman.

Genus (10) Potamocypris, G. S. Brady, 1870.

21. Potamocypris fulva, G. S. Brady.

1868. Bairdia fulva, Brady, Mon. rec. Brit. Ostrac., p. 474, pl. xxviii. fig. 21.

Hab.-Duddingston Loch, Loch Leven, Raith Lake, Loch Gelly, and several other places. Ben Ledi, at 2500 feet (Evans).

${ }^{1}$ Cypridopsis-Branchial platte des Kiefer fusses mit fünf Borsten. Furka verkümmert mit geisselförmiger Borste.

Cypridopsella-Branchial platte des Kiefer fusses mit zwei Borsten. Furke verkïmmert mit geisselförmiger Borste. 
Genus (11) Aglaia, G. S. Brady.

22. Aglaia complanata, G. S. Brady and D. Robertson.

1869. Aglaia complanata, B. and R., Ann. and Mag. Nat. Hist. (4), vol. iii. p. 66 , pl. xx. figs. 4,5 .

Hab.-Forth at Bo'ness (David Robertson). The late Dr Robertson, who obtained this rare form among some material collected by himself at Bo'ness, informed me in lit. of its occurrence there, but I have not met with it . myself.

Genus (12) Notodromas, Lilljeborg, 1853.

23. Notodromas monacha (O. F. Müller).

1785. Cypris monacha, Müller, Entomostraca, p. 60, taf. v. figs. 6-8.

Hab.-Pools on Luffness Links; in a pond near Musselburgh; Lochgelly Loch and Camilla Loch, Fifeshire. Burntisland Reservoir and Loch Rusky, 1906 (Evans).

Genus (13) Cyprois, Zenker, 1854.

24. Cyprois marginata (H. E. Straus).

1821. Cypris marginata, Straus, Mémoire sur les Cypris, Mém. du Mus., vol. vii. p. 59, pl. i. figs. 20-22.

1889. Cyprois flava, B. and N., l. c., Part I. p. 97, pl. viii. figs. 18, 19; pl. xii. figs. 13-21, 28.

Hab.-Duddingston Loch (A. M. Norman). In 1889 I found this species in moderate abundance at the upper end of the Loch-not in the Loch itself, but in little pools on the marshy ground behind the fringe of tall reeds. I observed it again in September 1898 on the same marshy ground, but not so plentiful as in 1889. I do not remember ever having found it in the loch itself. This species was collected by the late Mr James Bennie, of the Geological Survey, in a post-Tertiary fresh-water deposit at Kirkland of Leven, Fifeshire (cf. Proc. Roy. Phys. Soc., vol. x. pp. 335-337, 1890-91). 
Genus (14) Candona, Baird, 1845.

25. Candona candida (O. F. Müller).

1785. Cypris candida, Müller, Entomostraca, p. 62, taf. vi. figs. 7-9.

Hab. - This appears to be a moderately common species throughout the whole district.

\section{Candona neglecta, G. O. Sars.}

1887. Candona neglecta, G. O. Sars, Mittelh. Invert.-fauna IV., Ostrac. Mediterranea, p. 279, taf. xv. figs. 5-7; taf. xix. figs. 1-21.

1889. „, candida (Part), B. and N., l. c., Part I. p. 99, pl. x. figs. $20,21$.

Hab.-I find this species generally distributed but not very plentiful, and the males appear to be more frequent and larger than the females. The following are some of the places where it has been obtained:-Duddingston Loch $(\hat{\delta})$; Loch Leven ( $\hat{\delta})$; Linlithgow Loch ( $q$ ); Cocklemill Burn, near Largo ( $\hat{\sigma}$ and $\phi$ ); Lochgelly Loch $(\hat{\delta})$; Camilla Loch ( $\hat{\sigma}$ and ? $q$ ); Kinghorn Loch ( $\hat{o}$ ).

\section{Candona lactea, Baird.}

1850. Candona lactea, Baird, Proc. Zool. Soc. Lond. (1850), p. 255, pl. xviii. figs. 25-27.

Hab.-Duddingston Loch, Loch Leven, Camilla Loch, Linlithgow Loch, Loch Coulter, and other places within the area.

\section{Candona compressa (S. Fischer).}

1851. Cypris compressa, Fischer, Abhandl. über das genus Cypris, Mém. des Sav. étrang. des Sci. de St. Pétersh., t. 7, p. 144, taf. ii. figs. 7-12; taf. iii. figs. 1-5.

1889. Candona pubescens, B. and N., l. c., Part I. p. 101, pl. xii. figs. 32-37.

1900. ", compressa, Kaufmann, Cyprid. u. Darwinul., p. 371, taf. $x \times$ vii. figs. 4-6 et seq.

Hab.-Duddingston Loch (Brady and Norman), Lochgelly Loch, Loch Leven, and several other places within the district. 
29. Candona stagnalis, G. O. Sars.

1890. Candona stagnatis, G. O. Sars, Christ. Videns-Selsk. Forhandl., p. 69.

1891. ", ambigua, T. Scott, Ninth Rept. F. B. S., pt. iii. p. 277 , pl. iv. fig. 7 a-c.

Hab.-Lochgelly Loch and Loch Fitty, Fifeshire; not common.

30. Candona rostrata, Brady and Norman.

1889. Candona rostrata, B. and N., l. c., Part I. p. 101, pl. ix. figs. $11,12,12 \alpha, b$; pl. xii. figs. 22-31.

Hab-Duddingston Loch, Lurg Loch, Raith Lake, pond at Howietoun; not common. The larva of the tapeworm, Toenia gracilis, has been found encysted in a specimen of this species collected in Duddingston Loch. ${ }^{1}$

31. Candona faboformis (Fischer).

1851. Cypris fabceformis, Fischer, Über das genus Cypris, p. 146, pl. iii. figs. 6-16.

Hab.-Duddingston Loch; marl - pit, near Davidson's Mains, Edinburgh; pools on Luffness Links; Loch Fitty, and other places in Fifeshire; Linlithgow Loch; and in a pool near Howietoun.

32. Candona acuminata (Fischer).

1851. Cypris acuminata, Fischer, Üher das genus Cypris, p. 148, taf. iv. figs. 12-16.

Hab.-Ditch beside Harelaw Daw, Balerno; Threipmuir Reservoir; Loch Fitty; ponds at Howietoun; and Loch Coulter.

The specimens recorded here agree closely with the female of Candona caudata, figured by Kaufmann in Cypriden $u$. Darwinuliden der Schweiz, p. 365, taf. xxiv. figs. 16-20; taf. xxvi. figs. 17-23,

${ }^{1}$ Proc. Roy. Phys. Soc., vol. x. p. 314 (with text-figure), 1890-91. 
33. Candona hyalina, G. S. Brady and D. Robertson.

1870. Candona hyalina, B. and R., Ann. and Mag. Nat. Hist. (4), vol. vi. p. 18 , pl. ix. figs. $5-8$; pl. v. figs. 4.11.

1889. ", , B. and N., l.c., Part I. p. 247 , with textfigures 1-5.

Hab.-Threipmuir Reservoir, near Balerno (ô); Loch Fitty and Loch Gelly, Fifeshire; Loch Dow, Kinross-shire ( + ); Loch Katrine. The shell is much compressed, and of a white colour in living specimens. The dorsal edge is obtusely angular.

Genus (15) Candonopsis, Vavra, 1891.

34. Candonopsis Kingsleii (Brady and Robertson).

1870. Candona Kingsleii, B. and R., Ann. and Mag. Nat. Hist. (4), vol. vi. p. 17, pl. ix. figs. 9-12.

1891. Candonopsis kingsleii, Vavra, Mon. der Ostrac. Bohmens, p. 54, fig. 16.

Hab.-Duddingston Loch, pools on Luffiness Links, Lach Leven, Camilla Loch, Loch Coulter, Loch Katrine, and others. This is a well-marked and widely distributed species. . The shell in living specimens is white and much compressed.

Genus (16) Paracandona, Hartwig, 1899.

35. Paracandona euplectella (Robertson).

1880. Candona euplectella, Robertson, Fresh and Brackish-Water Ostrac. of Clydesdale, p. 23. (See also Proc. Nat. Hist. Soc. Glasgow, vol. iv. pt. i., 1880, p. 77.)

1900. Paracandona euplectella, G. W. Muiller, Deutschl. Süssw.Ostrac., p. 37, taf. ix. figs. 1-9, 14.

Hab.-Loch Dow, near Loch Glow, Kinross-shire, 14th September 1889. This is still the only record I have of $P$. euplectella from the district under consideration. It is the most beautiful of the species belonging to the British Candonoe. The shell is cylindrical and very tumid, and its structure is suggestive of the glass-sponge Euplectella, as implied by the specific name. 
Genus (17) Ilyocypris, Brady and Norman, 1889.

36. Ilyocypris gibba (Ramdohr).

1808. Cypris gibbc, Ramdohr, Mag. der Gesells. naturf. Freunde in Berlin, ii. p. 91, taf. iii. figs. 13-17.

Hab.-Union Canal, near Edinburgh, 4th September 1889. I obtained a number of specimens here-the only place where I have observed it within the district. The shell of this species is ornamented with prominent tubercles.

37. Ilyocypris bistrigata (Jurine).

1820. Monoculus bistrigatus, Jurine, Hist. Nat. des Monocles, p. 177, pl. xix. figs. $12,13$.

1838. Cypris biplicata, Koch, Deutschlands Crustaceen, H. 21 (161), fig. xvi.

Hab.-Duddingston Loch, Loch Leven, etc. This species is generally distributed throughout the district. I have occasionally observed specimens distinctly larger than some of the others, but could find no other difference sufficient to permit of their separation even as a variety.

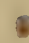

Genus (18) Pontocypris, G. O. Sars, 1865.

38. Pontocypris mytiloides (Norman).

1862. Cythere mytiloides, Norman, Ann. and Mag. Nat. Hist. (3), vol. ix. p. 50, pl. iii. figs. 1-3.

Hab.-Off Aberlady, off Musselburgh, and various other parts of the Forth estuary. Living specimens are usually moderately dark in colour.

39. Pontocypris acupunctata, G. S. Brady.

1866. Pontocypris acupunctata, Brady, Brit. Assoc. Report (1866), p. 209.

1868. " " Brady, Mon. rec. Brit. Ostrac., p. 386, pl, xxiv. figs: $53-56$.

$H a b$. - Off St Monans and one or two other places in the estuary, 1890; rare. Living specimens are brownish in colour, and the surface is minutely punctate.

40. Pontocypris trigonella, G. O. Sars.

1865. Pontocypris trigonella, G. O. Sars, Oversigt af Norges mar. Ostrac., p. 16.

Hab.-Largo Bay and other parts of the estuary; but not very common. 
Genus (19) Argillœcia, G. O. Sars, 1865.

41. Argilloecia cylindrica, G. O. Sars.

1865. Argillocia cylindrica, G. O. Sars, l. c., p. 18.

Hab.-Firth of Forth (Brady and Robertson). Off St Monans, rare.

Family B A I R D I I $Æ$.

Genus (20) Bairdia, M‘Coy (? 1849).

42. Bairdia inflata (Norman).

1862. Cythere inflata, Norman, Ann. and Mag. Nat. Hist. (3), vol. ix. p. 49, pl. iii. figs. 6-8.

1868. Bairdia inflata, Brady, Mon. rec. Brit. Ostrac., p. 388, pl. xxvii. figs. 9-17; pl. xxxviii. fig. 5.

Hab.-Dredged off St Monans, 1889; rare. The specimens were of a brownish colour, and tumid, as indicated by the name.

Family D A R W I N U L I D Æ.

Genus (21) Darwinula, Brady and Robertson, 1885.

43. Darwinula Stevensoni, Brady and Robertson. 1870. Polycheles Stevensoni, B. and R., Ann. and Mag. Nat. Hist. (4), vol. vi. p. 25, pl. vii. figs. 1-7; pl. ii. figs. 4-14.

Hab.-Loch Lubnaig, Perthshire, rare; obtained near the east shore by hand-net on 29th September 1894. This somewhat rare species was obtained by the late James Bennie in a lacustrine deposit in the Meadows, Edinburgh. (Cf. "The Ancient Lakes of Edinburgh," by James Bennie and T. Scott, Proc. Roy. Phys. Soc. Edin., vol. x. p. 131.)

Family C Y THERID Æ.

Genus (22) Cythere, O. F. Müller, 1785.

44. Cythere lutea, O. F. Müller.

1785. Cythere lutea, Müller, Entomostraca, p. 65, taf. vii. figs. 3,4 .

Hab.-Forth estuary, especially inshore-a common British species. 
45. Cythere pellucida, Baird.

1850. Cythere pellucida, Baird, Brit. Entom., p. 173, pl. xxi. fig. 7.

Hab.-Cramond Island, taken with hand-net at low water in 1889 , and subsequently in other parts of the estuary, chiefly in brackish water.

46. Cythere confusa, Brady and Norman.

1865. Cythere pellucida, G. O. Sars (not Baird), Oversigt af Norges mar. Ostrac., p. 31

1889. , confusa, B. and N., l. c., Pt. I. p. 127, pl. xiv. figs. 16-18.

Hab.-Largo Bay, off Musselburgh, and other places; moderately frequent.

47. Cythere porcellanea, G. S. Brady.

1889. Cythere porcellanea, B. and N., l. c., Pt. I. p. 127, pl. xiv. figs. 22-24.

Hab. - South Bay, off Musselburgh, and other places, but for the most part in shallow water that is slightly brackish.

48. Cythere tenera, G. S. Brady.

1868. Cythere tenera, Brady, Mon. rec. Brit. Ostrac., p. 599, pl. xxviii. figs. 29-32.

Hab.-South Bay, and deep water west of May Island; not common.

49. Cythere semipunctata, G. S. Brady.

1868. Cythere (?) semipunctata, Brady, Mon. rec, Brit. Ostrac., p. 411, pl. xxix. figs. 33-37.

Hab.-Aberlady Bay and Largo Bay; not common.

50. Cythere crispata, G. S. Brady.

1889. Cythere crispata, B. and N., l. c., Pt. I. p. 131, pl, xv. figs. $1,2$.

Hab.-Off the west side of Inchkeith; scarce.

51. Cythere gibbosa, Brady and Robertson.

1869. Cythere gibbosa, B. and R., Ann. and Mag. Nat. Hist. (4), vol. iii. p. 368 , pl. xxi. figs. 1-3.

Hab.-Brackish pools at the mouth of the Cocklemill Burn, Largo Bay, 1890. 
52. Cythere semiovata, 'T. Scott.

1890. Cythere semiovata, T. Scott, Eighth Rept. F. B. S., pt. iii. p. 321 , pl. xii. figs. $1,2$.

1896. ", $\quad$, $\quad$ B. and N., l. c., Pt. II. (Appendix) p. 732, pl. lxiii. figs. 14, 15.

Hab.-Off St Monans, frequent. I had at first some doubt concerning the validity of this species, but having as yet seen no described form with which it could agree, either as adult or young, it is retained in this Catalogue. In the original description of the species, "anterior" end should read "posterior" end, and vice versa.

53. Cythere albomaculata, Baird.

1850. Cythere albomaculata, Baird, Brit. Entomostraca, p. 169, pl. $x \times$. fig. 7 .

Hab.-Off Bo'ness and throughout the estuary, but apparently not very plentiful.

54. Cythere Robertsoni, G. S. Brady.

1868: Cythere Robertsoni, Brady, Ann. and Mag. Nat. Hist. (4), vol. ii. p. 33, pl. iv. figs. 5, 8-10.

Hab.-Dredged in the neighbourhood of Inchkeith, as well as in other parts of the estuary, but not very common.

\section{Cythere convexa, Baird.}

1850. Cythere convexa, Baird, Brit. Entomostraca, p. 174, pl. xxi. fig. 3.

Hab.-Firth of Forth; distribution similar to that of C. Robertsoni, but it appears to be even scarcer. I have observed it only sparingly.

56. Cythere limicola, A. M. Norman.

1865. Cythere limicola, Norman, Nat. and Mag. Hist. Trans.

Northumb. and Durham, vol. i. p. 20, pl. vi.

Hab.-South Bay, and in deep water west of May Island (1888). I find this to be a moderately rare species in the Firth of Forth. 
57. Cythere cuneiformis, G. S. Brady.

1868. Cythere cuneiformis, Brady, Mon. rec. Brit. Ostrac., p. 404, pl. xxxi. figs. 47-54.

Hab.-Aberlady Bay in 3 fathoms, bottom muddy sand; rare.

58. Cythere navicula (A. M. Norman).

1869. Cytherura navicula, Norman, Brit. Assoc. Rept. for 1868, p. 292.

Hab.-Off St Monans; not common.

59. Cythere villosa, G. O. Sars.

1865. Cythere villosa, G. O. Sars, Oversigt af Norges marine Ostracoder, p. 42.

Hab.-South Bay, off Inchkeith, and at various other places; frequent.

60. Cythere pulchella, G. S. Brady.

1868. Cythere pulchella, Brady, Mon. rec. Brit. Ostrac., p. 404.

Hab.-Firth of Forth (Brady and Norman). Off St Monans; not common. Without careful examination this species might be mistaken for the more common C. villosa.

61. Cythere quadridentata, Baird.

1850. Cythere quadridentata, Baird, Brit. Entom., p. 173, pl. xxi. fig. 2.

Hab.-OOff the west side of Inchkeith (1888), and subsequently, but very sparingly, in other parts of the estuary.

62. Cythere emaciata, G. S. Brady.

1867. Cythere emaciata, Brady, Brit. Assoc. Rept. for 1866 , p. 210.

Hab. - Firth of Forth, taken from the stomach of a Sharptailed Lumpenus, L. lampretiformis, captured at Station III. (east of Inchkeith), 13th July 1901. This is the only record I have of $C$. emaciata for the Forth estuary.

63. Cythere tuberculata, G. O. Sars.

1865. Cytheris tuberculata, G. O. Sar's, Oversigt af Norges marine Ostracoder, p. 37.

Hab.-South Bay; deep water west of May Island and other parts of the estuary; frequent. 
64. Cythere concinna, Rupert Jones.

1856. Cythere concinna, Jones, Tert. Entom., p. 29, pl. iv. fig. $7 a-f$.

Hab. - South Bay, Largo Bay, west of May Island; not very common. Firth of Forth (Brady and Norman).

65. Cythere finmarchica (G. O. Sars).

1865. Cythereis finmarchica, G. O. Sars, Oversigt af Norges marine Ostracoder, p. 41.

Hab.-Off St Monans, frequent (1890).

66. Cythere angulata (G. O. Sars).

1865. Cythereis angulata, G. O. Sars, l. c., p. 40.

Hab.-Firth of Forth (Brady and Norman). Dredged in deep water west of May Island, not common; and subsequently in one or two other parts of the estuary.

67. Cythere dunelmensis (Norman).

1865. Cythereis dunelmensis, Norman, Nat. Hist. Trans. Northumb. and Durh., vol. i. p. 22, pl. vii. figs. 1-4.

Hab.-Firth of Forth (Brady and Norman). Dredged in deep water west of May Island, 1888.

68. Cythere antiquata (Baird).

1857. Cythereis antiquata, Baird, Brit. Entom., p. 176, pl. xx. fig. 2.

Hab.-Firth of Forth (Brady and Norman). Dredged near Inchkeith and in South Bay; not common.

69. Cythere Whitei (Baird).

1850. Cythereis Whitei, Baird, l. c., p. 175 , pl. xx. figs. $3,3 a$.

Hab.-Largo Bay; not common.

70. Cythere Jonesii (Baird).

1850. Cythereis Jonesii, Baird, l. c., p. 175, pl. xx. fig. 1.

Hab.-South Bay, deep water west of May Island, and other places in the estuary; not common.

VOL. XVI. 
Genus (23) Limnicythere, G. S. Brady, 1867.

71. Limnicythere inopinata (Baird).

1850. Cythere inopinata, Baird, $l_{0} c_{.}$, p. 172, pl. xxi. figs. 1,1 a-e.

Hab.-Duddingston Loch, Loch Leven, Linlithgow Loch, Kilconquhar Loch, Lochgelly Loch, and other places. It is a small species that lives 'amongst the mud, and is easily missed.

72. Limnicythere Sancti-Patricii, G. S. Brady and D. Robertson.

1869. Limnicythere Sancti-Patricii, B. and R., Ann. and Mag. Nat. Hist. (4), vol. iii. p. 17, pl. xviii. figs. 8-11; pl. xxi. tig. 4.

Hab.-Loch Leven, moderately frequent. This is the only loch within the district where this species has been observed.

Genus (24) Cytheridea, Bosquet, 1852.

73. Cytheridea elongata, Brady.

1868. Cytheridea elongata, Brady, Mon. rec. Brit. Ostrac., p. 421, pl. xxviii. figs. 13-16; pl. xl. fig. 6 .

Hab.-Firth of Forth (G. S. Brady). Off the west side of Inchkeith, and a few other parts of the estuary; not common.

74. Cytheridea papillosa, Bosquet.

1862. Cytheridea papillosa, Bosq., Entom. fossil des terrains de la France, p. 42, pl. ii. fig. $5 a-d$.

Hab.-South Bay, off North Berwick, and some other places; not common.

75. Cytheridea punctillata, Brady.

1865. Cytheridea punctillata, Brady, Ann. and Mag. Nat. Hist. (3), vol. xvi. p. 189, pl. ix. figs. 9-11.

Hab.-Aberlady Bay, Largo Bay, and other places.

76. Cytheridea torosa (Jones).

1850. Candona torosa, Jones, Ann. and Mag. Nat. Hist. (2), vol, vi. p. 27 , pl. iii. fig. 6 .

Hab.-Granton Harbour (D. Robertson); brackish-water 
pools on the shore at Aberlady; pools in an old brickfield at Seafield, near Dunbar; mouth of the Cocklemill Burn, Largo Bay.

77. Cytheridea lacustris (G. O. Sars).

1862. Cythere lacustris, G. O. Sars, Zoolgisk Reise i. Sommeren, 1862 , p. 30.

Hab.-Union Canal, near Edinburgh (D. Robertson); Loch Leven, moderately frequent.

Genus (25) Eucythere, G. S. Brady, 1868.

78. Eucythere declivis (Norman).

1864. Cythere declivis, Norman, Nat. Hist. Trans. Northumb. and Durh., vol. i. p. 16, pl. v. figs. 9-12.

Hab.-Off the west side of Inchkeith and various other places; frequent.

Genus (26) Krithe, G. S. Brady, Crosskey, and Robertson, 1874.

79. Krithe bartonensis (T. R. Jones).

1856. Cytherideis bartonensis, Jones, Mon. Ter. Entom., p. 50, pl. v. figs. $2 a, b ; 3 a, b$.

Hab.-Near the mouth of the Forth estuary; moderately common.

Genus (27) Loxoconcha, G. O. Sars, 1862.

80. Loxoconcha impressa (Baird).

1850. Cythere impressa, Baird, Brit. Entom., p. 173, pl. xxi. fig. 9.

Hab.-Aberlady Bay, Largo Bay, and other parts of the estuary; frequent.

81. Loxoconcha guttata (Norman).

1864. Cythere guttata, Norman, Nat. Hist. Trans. Northumb. and Durh., vol. i. p. 19, pl. vi. figs. 9-12.

Hab.-Firth of Forth (Brady and Norman), South Bay and off North Berwick; frequent. 
82. Loxoconcha viridis (O. F. Müller).

1785. Cythere viridis, Müller, Entomostraca, p. 64, taf. vii. figs. $1,2$.

Hab.-Granton Harbour (D. Robertson); Largo Bay, rather rare.

83. Loxoconcha multifora (Norman).

1864. Cythere multifora, Norman, Nat. Hist. Trans. Northumb. and Durh., vol. i. p. 18, pl. vi. figs. 13-16.

Hab.-Granton Harbour (D. Robertson). This is the only record for the Forth known to me. The species is, however, widely distributed, and is likely to occur in other parts of the estuary.

84. Loxoconcha pusilla, Brady and Robertson.

1870. Loxoconcha pusilla, B. and R., Ann. and Mag. Nat. Hist. (4), vol. vi. p. 23, pl. viii. figs. 1-3.

$H a b$. - Taken in the vicinity of Cramond Island where the water is somewhat brackish; apparently rare. Firth of Forth (Brady and Norman).

85. Loxoconcha tamarindus (T. R. Jones).

1856. Cytherideis tamarindus, Jones, Tert. Entom., p. 49, pl. iii. figs. $4 a, 4 b$.

Hab.-Near Inchkeith, South Bay, and off North Berwick; frequent.

86. Loxoconcha fragilis, G. O. Sars.

1865. Loxoconcha fragilis, G. O. Sars, Oversigt af Norges marine Ostracoder, p. 65.

Hab.-Firth of Forth (Brady and Norman). This appears to be a rare species in the estuary. I have not myself observed it.

Genus (28) Xestoleberis, G. O. Sars, 1865.

87. Xestoleberis aurantia (Baird).

1835. Cythere aurantia, Baird, Mag. Zool. and Bot., vol. ii. p. 143, pl. v. fig. 26.

Hab.-Off St Monans, Aberlady Bay, Largo Bay, etc., but not very plentiful. 
88. Xestoleberis depressa, G. O. Sars.

1865. Xestoleberis depressa, G. O. Sars, Oversigt af Norges marine Ostracoder, p. 68.

$H a b$. - Off the west side of Inchkeith; rather rare.

Genus (29) Cytherura, G. O. Sars, 1865.

89. Cytherura gibba (O. F. Müller).

1785. Cythere gibba, Müller, Entomostraca, p. 66, pl. vii. figs. 7,8 . 1889. Cytherura gibba, B. and N., l. c., Part I., p. 190, pl. xviii. figs. $13-16$; pl. xxii. figs. $6-12$; pl. xxiii. fig. 8 .

Hab.-Granton Harbour (D. Robertson), Largo Bay, and off Aberlady.

90. Cytherura cornuta, G. S. Brady.

1838. Cytherura cornuta, Brady, Mon. rec. Brit. Ostrac., p. 445, pl. xxxii. figs. 12-15.

Hab.-Near Fidra Island; off Musselburgh, and Burntisland.

91. Cytherura sella, G. O. Sars.

1865. Cytherura sella, G. O. Sars, l. c., p. 73.

Hab.-Largo Bay, South Bay, and other parts of the estuary; moderately frequent.

92. Cytherura acuticostata, G. O. Sars.

1865. Cytherura, acuticostata, G. O. Sars, $\ell$. c., p. 76.

Hab.-Dredged off the west side of Inchkeith. This is said to be one of the commonest species belonging to the Cytheruroe.

93. Cytherura bodotria, T. Scott.

1890. Cytherura bodotria, T. Scott, Eighth Rept. F. B. S., part iii. p. 232, pl. xii. figs. 6,7 .

1896. ", ", B. and N., l. c., Part II. (Appendix) p. 736, pl. xiv. figs. 16,17 .

Hab.-Dredged off St Monans; rare. This species has also been obtained in the Firth of Clyde.

The authors of the Monograph referred to above are inclined to think that this form "must be regarded as the young of 
Cytherura acuticostata," and in support of this view they state that though they do not have very young examples of that species to compare it with, a very fine series of the young of the $C$. cornuta shows that "the beak occupies a much larger proportion of shell, and is thus more prominently conspicuous" in the young of the Cytherurce, and "that the lateral projections are also more acute than in the adult." 1 These remarks are supported by an indifferent outline sideview of young forms of $C$. cornuta and $C$. nigrescens, but I think for the purpose of comparison a dorsal view should also have been given. I am, however, not extremely anxious whether the "species" stands or not, and therefore will not discuss its merits here. There are one or two points, however, that may be referred to-(1st) If a careful comparison of the original figures of $C$. bodotria be made with those of C. acuticostata given on plate xxxii. (figs. 12-15) of Dr Brady's excellent "Monograph of recent British Ostracoda," published in the Transactions of the Linnean Society, 1868, it will be seen that $C$. bodotria is proportionally more elongated and more depressed, and that, when seen from above, the lateral angles are remarkably prominent and not like the species it is said to be the young of ; but (2nd), and leaving these differences meanwhile out of account, and taking for granted that Cytherura bodotria is the young of Cytherura acuticostata, then from what happens with other species one might expect these young to be smaller than the adult, but they are not so. The length of the specimen of $C$. bodotria represented by our drawings in Part III. of the Eighth Annual Report of the Fishery Board for Scotland was $5 \mathrm{~mm}$., and the size of C. acuticostata as given in the Monograph already referred to at page 446 , and which I. suppose represents the adult size, is the $\frac{1}{50}$ th of an inch, so that this supposed young form is as big as the one full grown.

But I had even a better and larger specimen of $C$. bodotria than the one figured, though it was similar in form and sculpture, and it would have been figured instead, but it was

${ }^{1}$ I have two smaller (younger) specimens of $C$. bodotria, and these have the lateral projections less developed than in the one figured, though otherwise similar to it. 
unfortunately accidentally crushed by the object-glass of the microscope having been lowered down on it. I have examined a considerable number of $C$. acuticostata and allied forms, but have failed to observe any with which $C$. bodotria could be incorporated.

94. Cytherura striata, G. O. Sars.

1865. Cytherura striata, G. O. Sars, l.c., p. 74.

Hab.-Off Musselburgh, Largo Bay, and other parts of the estuary; moderately frequent.

95. Cytherura angulata, G. S. Brady.

1868. Cytherura angulata, Brady, Monograph recent British Ostracoda, p. 440, pl. xxxii. figs. 22-25.

Hab.-Dredged off the west side of Inchkeith and other parts of the estuary, but not very plentiful.

96. Cytherura undata, G. O. Sars.

1865. Cytherura undata, G. O. Sars, l. c., p. 75.

Hab.-Dredged off Musselburgh, and off the west side of Inchkeith and other places. It appears to be generally distributed, but being very small (about the $\frac{1}{65}$ th of an inch in length) it is easily overlooked.

97. Cytherura producta, G. S. Brady. 1868. Cytherura producta, Brady, Mon. rec. Brit. Ostrac., p. 443, pl. xxxii. figs. 60,61 .

1890. ", mucronata, T. Scott, Eighth Rept. F. B. S., pt. iii. p. 323, pl. xii. figs. 3-5 (? juv.).

Hab.-Dredged in Largo Bay and off St Monans, but not very common.

98. Cytherura nigrescens (Baird).

1850. Cythere nigrescens, Baird, Brit. Entom., p. 171, pl. xxi. figs. $4,4 a$.

Hab. - South Bay, off Musselburgh, common. It has also been observed in other parts of the estuary. 
99. Cytherura simplex, Brady and Norman.

1889. Cytherura simplex, B. and N., l. c., Pt. I. p. 200, pl. xviii. figs. 1, 2.

Hab.-Off St Monans, frequent, in 12 to 15 fathoms, bottom partly clean sand and partly gravel.

100. Cytherura similis, G. O. Sars.

1865. Cytherura similis, G. O. Sars, Oversigt af Norges marine Ostracoder, p. 72.

Hab.-Dredged off Musselburgh and in Largo Bay; not very common.

101. Cytherura clathrata, G. O. Sars.

1865. Cytherura clathrata, G. O. Sars, l. c., p. 77.

Hab.-Bo'ness, Firth of Forth (Brady and Robertson). Dredged off Bo'ness, off the west side of Inchkeith, and other parts of the Forth; not common.

102. Cytherura cellulosa, A. M. Norman.

1865. Cytherura cellulosa, Norman, Nat. Hist. Trans. Northumb. and Durh., vol. i. p. 22, pl. v. figs. 17-20; pl. vi. fig. 17 .

Hab.-South Bay, and in other parts of the estuary, but apparently not common; but as it only measures $\frac{1}{70}$ of an inch (about $\cdot 36 \mathrm{~mm}$.) it may have frequently been overlooked.

Genus (30) Cytheropteron, G. O. Sars, 1865.

103. Cytheropteron latissimum (Norman).

1865. Cythere latissima, Norman, l. c., vol. i. p. 19, pl. vi. figs. 5-8.

$H a b$.-Dredged in South Bay, and in deep water west of May Island; frequent.

104. Cytheropteron nodosum, G. S. Brady.

1868. Cytheropteron nodosum, Brady, Mon. rec. Brit. Ostrac., p. 448, pl. xxxiv. figs. 31-34.

Hab.-Firth of Forth (Brady and Robertson). South Bay, off Musselburgh; not unfrequent. 
105. Cytheropteron punctatum, G. S. Brady.

1868. Cytheropteron punctatum, Brady, l. c., p. 449, pl. xxxiv. figs. 45-48.

Hab.-Dredged off St Monans; rather rare.

106. Cytheropteron angulatum, Brady and Robertson.

1872. Cytheropteron angulatum, B. and R., Ann. and Mag. Nat. Hist. (4), vol. ix. p. 62, pl. ii. figs. $7,8$.

Hab.-Largo Bay and off Aberlady; rare.

107. Cytheropteron depressum, Brady and Norman.

1889. Cytheropteron depressum, B. and N., l. c., Pt. I. p. 218, pl. xx. figs. $22,23$.

Hab.-Largo Bay and off Aberlady; not common.

108. Cytheropteron humile, Brady and Norman.

1889. Cytheropteron humile, B. and N., l. c., Pt. II. p. 220, pl. xx. figs. 4-7.

Hab.-Dredged off Limekilns and in Largo Bay. This small species, which measures only $33 \mathrm{~mm}$., has also been found fairly plentiful in the Clyde in the crevices of partly decayed pieces of wood brought up in the dredge, and usually associated with an interesting species of Copepoda, Harrietella simulans, T. Scott.

Genus (31) Bythocythere, G. O. Sars, 1865.

109. Bythocythere turgida, G. O. Sars.

1865. Bythocythere turgida, G. O. Sars, l. c., p. 84.

Hab.-Dredged off Musselburgh and other places; not common. This moderately large species has sometimes been obtained in the stomachs of small fishes.

110. Bythocythere constricta, G. O. Sars.

1865. Bythocythere constricta, G. O. Sars, $l$. c. p. 85

$H a b$. - Largo Bay and off Aberlady; frequent. This is a moderately common species in the Forth. 
111. Bythocythere simplex (Norman).

1865. Cythere simplex, Norman, Nat. Hist. Trans. Northumb. and Durh., vol. i. p. xvii, pl. v. figs. 1-4.

Hab.-South Bay, in deep water west of May Island, and other places, but not very common. This is a fine large species, conspicuous from its white colour; it forms part of the food of young Gadoids, Rocklings, Lumpenus, Long Rough Dabs, and other fishes.

112. Bythocythere recta, G. S. Brady.

1868. Cytheropteron rectum, Brady, Mon. rec. Brit. Ostrac., p. 476.

Hab.-Largo Bay; rare.

Genus (32) Pseudocythere, G. O. Sars, 1865.

113. Pseudocythere caudata, G. O. Sars.

1865. Pseudocythere caudata, G. O. Sars, Oversigt af Norges marine Ostracoder, p. 88.

Hab. - Firth of Forth (Brady and Robertson). Off St Monans; frequent.

Genus (33) Sclerochilus, G. O. Sars, 1865.

114. Sclerochilus contortus (Norman).

1862. Cythere contorta, Norman, Ann. and Mag. Nat. Hist. (3), vol. ix. p. 48 , pl. ii. fig. 15 .

$H a b$.--South Bay, and in deep water west of May Island; frequent.

Genus (34) Cytherideis, T. R. Jones, 1856.

115. Cytherideis subulata, G. S. Brady.

1868. Cytherideis subulata, Brady, Mon. rec. Brit. Ostrac., p. 454, pl. xxxv. figs. 43-46.

$H a b$. - Dredged off the west side of Inchkeith and other parts in the estuary; not very common.

Genus (35) Cytherois, W. Müller, 1884.

116. Cytherois Fischeri (G. O. Sars).

1865. Paradoxostoma Fischeri, G. O. Sars, $l_{\text {. c }}$, p. 96.

Hab._Off Aberlady and St Monans; frequent. 
Genus (36) Paradoxostoma, Fischer, 1851.

117. Paradoxostoma variabile (Baird).

1835. Cythere variabilis, Baird, 'Trans. Berw. Nat. Club, vol. i. p. 98 , pl. iii. fig. $7 a, b$.

Hab.-Largo Bay, and generally throughout the estuary, especially in the littoral and laminarian zones.

118. Paradoxostoma ensiforme, G. S. Brady.

1868. Paradoxostoma ensiforme, Brady, Mon. rec. Brit. Ostrac., p. 460 , pl. xxxv. figs. 8-11.

Hab.-Dredged off the west side of Inchkeith; off Musselburgh and elsewhere.

119. Paradoxostoma abbreviatum, G. O. Sars.

1865. Paradoxostoma abbreviatum, G. O. Sars, Oversigt af Norges marine Ostracoder, p. 94.

Hab.-Off Musselburgh; not very common. Easily distinguished from its being remarkably short in comparison to the height; there is also a perceptible difference in the contour of the shell when seen from the side.

120. Paradoxostoma obliquum, G. O. Sars.

1865. Paradoxostoma obliquum, G. O. Sars, l. c., p. 97.

Hab.-Off Fidra, Musselburgh, and Burntisland; moderately rare. This species is more tumid as viewed from above when compared with most of the other British species.

121. Paradoxostoma pulchellum, G. O. Sars.

1865. Paradoxostoma pulchellum, G. O. Sars, l. c., p. 95.

Hab.-Dredged off Musselburgh; moderately rare.

122. Paradoxostoma hibernicum, G. S. Brady.

1868. Paradoxostoma hibernicum, Brady, l. c., p. 460, pl. xxxv. figs. 35,36 ; pl. xl. fig. 7 .

Hab.-Largo Bay; rather rare.

123. Paradoxostoma arcuatum, G. S. Brady.

1868. Paradoxostoma arcuatum, Brady, l. c., p. 461, pl. xxxv. fig. 37.

Hab.-Granton (Brady and Robertson), Off St Monans, Largo Bay, and vicinity of Inchkeith; rare. 
124. Paradoxostoma orcadense, G. S. Brady and D. Robertson.

1872. Paradoxostoma orcadense, B. and R., Ann. and Mag. Nat. Hist. (4), vol. ix. p. 53, pl. i. figs. 5-7.

Hab.-Off St Monans ; rare.

125. Paradoxostoma Hodgei, G. S. Brady.

1870. Paradoxostoma Hodgei, Brady, Nat. Hist. Trans. Northumb. and Durh., vol. iii. p. 371, pl. xii. figs. 12, 13.

Hab.-Off St Monans, frequent; also near Fidra.

126. Paradoxostoma flexuosum, G. S. Brady.

1868. Bythocythere (?) flexuosa, Brady, Brit. Assoc. Report (1866), p. 211.

1889. Paradoxostoma flexuosum, B. and N., l. c., Part I. p. 236, pl. xxi. figs. 11, 12.

Hab.-Firth of Forth (Brady and Robertson). Off Bo'ness, South Bay, and other parts of the estuary; frequent.

\section{Paradoxostoma affine, T. Scott.}

1890. Paradoxstoma affine, T. Scott, Eighth Rept. F. B. S., pt. iii. p. 325 , pl. xii. figs. $8,9$.

1896. „, , B. and N., l. c., Part II. (Appendix) p. 739 , pl. lxiii. figs. 10,11 .

Hab.-Off St Monans; not common. The species which this form most closely resembles is the Paradoxostoma arcuatum of G. S. Brady, but it is not so narrow posteriorly, and its greatest breadth is nearer the posterior extremity. It has also been taken by Canon Norman near Inveraray, Loch Fyne.

Genus (37) Machærina, Brady and Norman, 1889.

128. Machorina tenuissima (Norman).

1869. Bythocythere tenuissima, Norman, Brit. Assoc. Rept. for 1868 , p. 294.

Hab.-Dredged in deep water west of May Island; not common. Also observed in the stomach of a Five-bearded Rockling captured in the Forth on 13th May 1901. This species is remarkably compressed, and though moderately high in the middle, both ends taper gradually to a narrow point, imparting to the shell a very slender appearance. 
Section II. Mrodocopa.

Family Ast E R O ID E, Brady and Norman.

Genus (38) Asterope, Philippi, 1840.

129. Asterope marioe (Baird).

1850. Cypridina marioe, Baird, Proc. Zool. Soc. Lond., pt. xviii. p. 257, pl. xvii. figs. 5-7.

1896. Asterope marioe, B. and N., l. c., Part II. p. 630, pl. 1. figs. 1-6 et seq.

Hab.-Dredged near the Bass Rock; not common.

Family CYPRINID E, Baird, 1850.

Genus (39) Philomedes, Lilljeborg, 1853.

130. Philomedes interpuncta (Baird).

1850. Cypridina interpuncta, Baird, l.c., p. 257, pl. xvii. figs. 8-10.

Hab.- South Bay, off west side of Inchkeith, and other parts of the estuary; sometimes taken with the tow-net, and often with the dredge.

Section III. Cladocopa, G. O. Sars, 1865.

Family POL YCOPIDE.

Genus (40) Polycope, G. O. Sars, 1868.

131. Polycope orbicularis, G. O. Sars.

1865. Polycope orbicularis, G. O. Sars, Oversigt af Norges marine Ostracoder, p. 122.

Hab.-Dredged near Fidra, Firth of Forth; rare.

Genus (41) Polycopsis, G. W. Müller, 1894.

132. Polycopsis compressa (Brady and Robertson). 1869. Polycope compressa, B. and R., Ann. and Mag. Nat. Hist. (4), vol. iii. p. 20, pl. xxi. figs. 5-11.

Hab._Off St Monans; frequent.

It will be observed that the Ostracoda enumerated here amount to 132 species, and belong to 41 genera. There are 
some others which, judging from their distribution, may also occur within the Forth area, though hitherto they have escaped notice. I have already mentioned that Scottia Browniana has been observed in a lacustrine deposit at Elie, Fifeshire, and as it appears to be very local in its distribution, it may yet be found living somewhere within the district. Cypridopsis Newtoni is another that may be expected to occur in some of the inland waters, and there are also a few marine forms that are likely to be met with.

About 170 species have, I think, been recorded from Scotland (including the Orkney and Shetland Islands), and if those which have hitherto been only observed in the neighbourhood of Shetland be excepted, it will be found that fully 84 per cent. of the Scottish species are represented within the Forth area.

\section{Order COPEPODA.}

The Copepoda comprise a much larger number of species than any of the other Crustacean orders. The species enumerated here amount to 306, and include both freeswimming and parasitic forms.

Various methods have been adopted for the scientific arrangement of these organisms. In that used by Professor G. O. Sars in his great work on the Crustacea of Norway, now in course of publication, and which for the sake of uniformity I propose to follow generally, the Copepoda are separated into seven divisions, viz:- -1st, the Calanoida, most of which are free-living and pelagic; 2nd, the Harpacticoida, which for the most part are free-living but demersal; 3rd, the Cyclopoida, some of which are free-living fresh-water species, while others are "semi-parasites," and live as commensals or messmates with various other organisms; 4th, the Notodelphyoida, which, for the most part, are "semi-parasites," associated with various Ascidians; 5th, the Monstrilloida, a small but curious group, which appear to live a partly parasitic and partly free life; 6th, the Caligoida, chiefly parasitic on fishes, but some of which possess a certain freedom of movement; and 7 th, the Lernæoida, fish para- 
sites, which, in the adult stage, are more or less permanently fixed on some part of the fish.

This arrangement does not differ greatly from that of Professor G. S. Brady's excellent Monograph of the Free and Semi-Parasitic Copepoda of the British Islands, except that the Cyclopidæ and Notodelphydæ are in that work placed between the Calanoids and Harpacticoids.

The species recorded in the sequel are distributed among the seven divisions as follows:-

1st. The Calanoida, represented by 30 species.

2nd. The Harpacticoida, " „170 "

3rd. The Cyclopoida, " " 59 "

4th. The Notodelphyoida, , " " 9 "

5th. The Monstrilloida, " " 5 "

6th. The Caligoida, " " 12 "

7th. The Lernæoida, " " 21 "

Total number, $\underline{\underline{306}}$

\section{Division Calanoida.}

In the arrangement and nomenclature of the species under this division, Professor G. O. Sars' work-An Account of the Crustacea of Norway, vol. iv., Copepoda Calanoida-is generally followed. See also Professor G. S. Brady's Monograph of the Free and Semi-Parasitic Copepoda of the British Islands, vol. i.

\section{Family CA L A N I D $A$.}

Genus (1) Calanus, Leach, 1816.

1. Calanus septentrionalis (Goodsir).

1843. Cetochilus septentrionalis, Goodsir, Edin. New Phil. Jour., vol. xxxv. p. 339, pl, vi. figs. 1-11.

1863. Calanus helgolandicus, Claus, Die frei-lebenden Copepoden, p. 171, pl. xxvi. figs. 2-9.

Hab.-Common in the Firth. Previously recorded as $C$. finmarchicus (Gunn.), but, as indicated by G. O. Sars, that species is slightly larger, and differs in some structural details, and its distribution appears for the most part to 
be confined to the arctic or subarctic seas. There seems to be little doubt that Cetochilus septentrionalis is identical with Calanus helgolandicus, Claus, and having priority in publication, it should have preference over $C$. helgolandicus.

Family P A R A A L A N I A, G. O. Sars, 1902.

Genus (2) Paracalanus, Boeck, 1864.

2. Paracalanus parvus (Claus).

1863. Calanus parvus, Claus, Die frei-lebenden Copepoden, p. 173, pl. xxvi. figs. $10-14$; pl. xxvii. figs. 1-4.

Hab.-Occasionally taken with the tow-net near the seaward limits of the Forth estuary, sometimes in moderate abundance, but usually it is a rather scarce species.

Family P S E D O C A L A N I D Æ.

Genus (3) Pseudocalanus, Boeck, 1872.

3. Pseudocalanus elongatus, Boeck.

1864. Clausia elongata, Boeck, Forhandl. Videnskabs-Selskabet, Christiania (1864), p. 9.

Hab.-Common throughout the estuary. Boeck described this species as Clausia elongata, but as that generic name had been previously used by Claparède for a genus of parasitic Copepods, he withdrew it and substituted the name Pseudocalanus.

Family E T I D E I

Genus (4) Bradyidius, Giesbrecht, 1897.

4. Bradyidius armatus (G. S. Brady).

1878. Pseudocalanus armatus, G. S. Brady, Monogr. Brit. Copep., vol. i. p. 46, pl. iv. figs. 1-11.

1897. Bradyidius armatus, Giesbrecht, Zool. Anzeiger, No. 536.

1898. " " T. Scott, Sixteenth F. B. Rept., pt. iii. p. 264, pl, xii. figs. 1-19.

1902. Undinopsis Bradyi, G. O. Sars, Crustacea of Norway, vol. iv. p. 32, pls. xix., $x x$.

Hab.-Off St Monans and a few other places near the 
seaward limits of the estuary. I have given several synonyms for this species, as there appears to be some doubt about the name that should be used for it.

Family $S$ T E P H I D Æ.

Genus (5) Stephos, T. Scott, 1892.

5. Stephos minor, T. Scott.

1892. Stephos minor, T. Scott, Tenth F. B. Rept., pt. iii. p. 245, pl. vii. figs. 1-13.

Hab.-Off St Monans and other parts of the estuary; not common. Dredged in 7 fathoms off the east side of Inchkeith, 23rd May 1901.

6. Stephos Scotti, G. O. Sars.

1897. Stephos gyrans, T. Scott (not S. gyrans, Giesb.), Firteenth F. B. Rept., pt. iii. p. 146 ; pl. ii. figs. $2-9$; pl. iii. figs. $17,18$.

1902. ", Scotti, G. O. Sars, Crustacea of Norway, vol. iv. p. 63, pl. xliii.

1903. " " , T. Scott, Twenty-first F. B. Rept., pt. iii. p. 110, pl. ii. figs. 1-4.

Hab.-Ootained in a gathering collected in 1892, but not examined till 1902; also in a gathering from an old quarry near Granton to which the sea has access, collected in 1894; rather rare.

Family PSEU D OCYCLOPIID

Genus (6) Pseudocyclopia, T. Scott, 1892.

7. Pseudocyclopia crassicornis, T. Scott.

1892. Pseudocyclopia crassicornis, T. Scott, Tenth F. B. Rept., pt. iii. p. 246, pl. vii. figs. 15-29.

Hab._-Off St Monans, 1891; off the east side of Inchkeith in May 1901, and at a few other places; not common.

8. Pseudocyclopia minor, T. Scott.

1892. Pseudocyclopia minor, T. Scott, Tenth F. B. Rept., pt. iii. p. 247, pl. viii. figs. 1-10.

Hab.-Off St Monans, 1891; not common. This is a smaller, and apparently a rarer species than the last.

VOL. XVI. 
9. Pseudocyclopia caudata, T. Scott.

1894. Pseudocyclopia caudata, T. Scott, Twelfth F. B. Rept., pt. iii. p. 236, pl. v. figs. 1-8.

Hab.-Off St. Monans in 1893; off the east side of Inchkeith, in about 5 fathoms, in May 1901.

10. Pseudocyclopia Giesbrechti, Wolfenden.

1902. Pseudocyclopia Giesbrechti, Wolfenden, Jour. M. B. A. Plymouth, January 1902, p. 370, pl. iv.

Hab.-West of Queensferry; rare. A single male was dredged to the west of Queensferry, 17th November 1893, but was only recently identified. A female (the one he describes and figures) was taken by Dr Wolfenden with a surface townet off the island of Bressay, Shetland, in March 1900.

Family CENTROPA GID

Genus (7) Centropages, Kröyer, 1848.

11. Centropages typicus, Kröyer.

1848. Centropages typicus, Kröyer, Naturh. Tidsskr. (N.S.), vol. ii. p. 588 , pl. vi. figs. $22-26$.

Hab.-Not uncommon in the seaward portion of the estuary, especially during summer; but it appears to become rarer in the winter months.

12. Centropages hamatus (Lilljeborg).

1853. Ichtyophorba hamata, Lillj., De Crust. ex ord. tribus in Scania occurrentibus, p. 185, pl. xxi.; pl. xxvi. figs. 9-12.

Hab.-This species, which is rather more common than the last, has a seasonal distribution somewhat similar to it.

Family D I A P T O M I D

Genus (8) Diaptomus, Westwood, 1836.

13. Diaptomus castor (Jurine).

1820. Monoculus castor, Jurine, Hist. des Monocles, p. 50, pl. iv. figs. 1-6 et seq.

$H a b$. - In an old quarry on the Braid Hills, Edinburgh, in April 1888: this quarry is now included within the public 
park. Roslin Curling Pond ( $\hat{\delta}$ and + ), 3rd March 1906 (Evans).

14. Diaptomus gracilis, G. O. Sars.

1862. Diaptomus gracitis, G. O. Sars, Oversigt af de indenlandske Ferskvandscopepoder, Chr. Vid.-Selsk. Forh., 1862, p. 9.

Hab.-Duddingston Loch, Loch Leven, and in most of the fresh-water lochs within the area; common. Loch a Chroin, 2500 feet, September 1.906 (W. Evans).

15. Diaptomus hircus, G. S. Brady.

1891. Diaptomus hircus, Brady, Nat. Hist. Trans. Northumb. and Durham, vol. ii. p. 35, p1. x. figs. 2-4.

Hab.-Loch Katrine,Trossachs, 16 th March 1898; rather rare.

16. Diaptomus Wierzejskii, J. Richard.

1888. Diaptomus Wierzejskii, Richard, Bull. Soc. Zool. de France, vol. xiii. p. 53.

1891. " sernicornis, Lillj., Brady, l. c., p. 36, pl. ix. figs. 3-10.

Hab.-Loch Achray, Trossachs, 27th November 1897. Though this is the only loch within the area of the Forth basin in which I have obtained Diaptomus Wierzejskii, it is a widely distributed species in the north of Scotland, Shetland, and the Outer Hebrides.

Family TEM O RID A.

Genus (9) Temora, Baird, 1830.

17. Temora longicornis (O. F. Müller).

1792. Cyclops longicornis, Müller, Entomostraca Daniæ et Norvigiæ, p. 115.

Hab.-Common, and generally distributed throughout the estuary.

Genus (10) Eurytemora, Giesbrecht, 1881.

18. Eurytemora velox (Lilljeborg).

1853. Temora velox, Lillj., De Crust. ord. tribus in Scania occurrentibus, p. 177, pl. xx. figs. 2-9 ( $\$$ ).

$H a b$.- In the estuary near South Queensferry. 
19. Eurytemora affinis (Poppe).

1881. Temora affinis, Poppe, Abhandl. d. Naturh. ver. Bremen, vol. vii. p. 55, pl. iii.

1891. Eurytemora affinis, G. S. Brady, Nat. Hist. Trans. Northumb., Durh., and Newcastle-upon-Tyne, vol. ix. p. 42, pl. xiii. figs. 6-9.

$H a b$. - Taken in the vicinity of Culross, and between Kincardine-on-Forth and Alloa, in July 1891 and February 1892 ; moderately common.

Family M E TRIDIID

Genus (11) Metridia, Boeck, 1864.

20. Metridia lucens, Boeck.

1864. Metridia lucens, Boeck, Chr. Vid.-Selsk. Forh., p. 238.

1878. , armata, G. S. Brady, Monograph, vol. i. p. 42, pl. ii. figs. 1-12.

Hab.-Obtained sparingly near the mouth of the estuary, and from there west to near Inchkeith.

Family PSE U D O C Y CL O P I D

Genus (12) Pseudocyclops, Brady, 1872.

21. Pseudocyclops crassiremis, G. S. Brady.

1872. Pseudocyclops crassiremis, Brady, Nat. Hist. Trans. Northumb. and Durham, vol. iv. p. 431, pl. xvii. figs. 1-8.

Hab.-Off St Monans, 1893; rare.

22. Pseudocyclops obtusatus, G. S. Brady and D. Robertson. 1873. Pseudocyclops obtusatus, B. and R., Ann. and Mag. Nat. Hist. (4), vol. xii. p. 128, pl. viii. figs. 4-7.

Hab.-Taken sparingly with the dredge off St Monans. Also off the north-west end of Inchkeith, in about 5 fathoms, on 23rd May 1901. 
Family C A N D A C I I D Æ.

Genus (13) Candacia, Dana, 1846.

23. Candacia armata, Boeck.

1872. Candace armata, Boeck, Nye Slægter og Arter SaltvandsCopepoder, Chr. Vid.-Selsk. Forh., p. 39.

1878. ', pectinata, Brady, Monograph, vol. i. p. 49, pl. viii. figs. 14,15 ; pl. x. figs. 1-12.

1902. Candacia armata, G. O. Sars, l. c., vol. iv. p 135, pl. xci.

Hab.-Occasionally captured with the tow-net between Inchkeith and May Island. This species appears to be more frequent in winter and spring than during the summer months.

Family P ONTELLID $\mathbb{E}$.

Genus (14) Anomalocera, Templeton, 1837.

24. Anomalocera Patersoni, Templeton.

1837. Anomalocera Patersoni, Templ., Trans. Ent. Soc. Lond., vol. ii. p. 35, pl, v. figs. 1-3.

$H a b$. - This species is, at times, moderately frequent in the Forth estuary, especially during summer and autumn.

Genus (15) Labidocera, Lubbock, 1853.

25. Labidocera Wollastoni, Lubbock.

1857. Pontella Wollastoni, Lubbock, Ann. and Mag. Nat. Hist. (2), vol. xx. p. 406, pls. x., xi.

$H a b$. - Off the east side of Inchkeith; collected 8th June 1891, but not examined till 1899 .

Family PARA PONTELLID ※.

Genus (16) Parapontella, G. S. Brady, 1878.

26. Parapontella brevicornis (Lubbock).

1857. Pontellina brevicornis, Lubbock, Ann. and Mag. Nat. Hist. (2), vol. xx. p. 407, pl. xi. figs. 4-8.

Hab.-This species has been observed above Queensferry, off Musselburgh, in the neighbourhood of Inchkeith, off the Wemyss, and in the neighbourhood of Dunbar. 
Family ACARTII Æ.

Genus (17) Acartia, Dana, 1846.

27. Acartia longiremis (Lilljeborg).

1853. Dias longiremis, Lillj., De Crust. ex ord. tribus in Scania occurrentibus, p. 181, pl. xxiv.

Hab.-Generally distributed throughout the estuary; not usually uncommon, but at some seasons it appears to be more numerous than at others.

28. Acartia Clausi, Giesbrecht.

1889. Acartia Clausi, Giesb., Atti Accad. Lincei Rend. Roma (4), vol. v. sem. 2, p. 25.

Hab.-The distribution and frequency of this species is somewhat similar to the last.

29. Acartia bifilosa, Giesbrecht.

1881. Dias bifilosus, Giesb., Zool. Anzeiger, vol. iv. p. 257.

1882. ," , Giesb., Die frei-leb. Copep. der Kieler Föhrde, p. 147, pl. iii. figs. 4, 22, 23 et seq.

Hab.-Taken in the vicinity of Culross, near the head of the estuary, in 1891.

30. Acartia discaudata, Giesbrecht.

1882. Dias discaudatus, Giesb., Die frei-leb. Copep. der Kieler Föhrde, p. 148, pl. iii. figs. 4, 22, 23 et seq.

Hab.-Collected with a tow-net between Portobello and Cockenzie in 1890, and on several subsequent occasions, chiefly in the same part of the estuary. The female of this species is readily distinguished by the character of the furcal joints, which are of the form of broad flattened plates fringed with stout and not very long setæ. 


\section{Division HARPACTICOIDA.}

I have decided to omit the separating of the Harpacticoida into families, because Professor G. O. Sars, in his work now in course of publication, is creating an entirely new arrangement of these Copepoda. The reader is therefore referred to vol. v. of The Crustacea of Norway, part of which is already published, for the systematic distribution of this group.

Genus (18) Misophria, Boeck, 1864.

31. Misophria pallida, Boeck.

1864. Misophria pallida, Boeck, Chr. Vidensk.-Selskab. Forhandl., p. 248.

1904. , , , Sars, Crustacea of Norway, vol. v. p. 6, pls. i., ii.

Hab. - Dredged off St Monans, west of Queensferry, and other parts of the estuary, but not very common.

Genus (19) Longipedia, Claus, 1863.

32. Longipedia Scotti, G. O. Sars.

1893. Longipedia coronata, T. and A. Scott (not $L$. coronata, Claus), Ann. Scot. Nat. Hist., vol. ii. pt. ii. p. 91, pl. ii. figs. 4-6.

1904. , Scotti, G. O. Sars, l. c., vol. v. p. 11, pl. v. fig. 1.

Hab.-Moderately common throughout the estuary.

33. Longipedia minor, T. and A. Scott. 1893. Longipedia coronata, var. minor, T. and A. Scott, Ann. Scot. Nat. Hist., vol, ii. p. 93.

1893. , , , „, T. Scott, Eleventh F. B. Rept., pt. iii. p. 200, pl. ii. figs. 14-20.

1904. „ minor, G. O. Sars, l. c., vol, v. p. 12, pl. v. fig. 2.

Hab.-Not uncommon in various parts of the estuary, as off Musselburgh, Largo Bay, etc. 
Genus (20) Canuella, T. and A. Scott, 1893.

34. Canuella perplexa, T. and A. Scott.

1893. Canuella perplexa, T. and A. Scott, . c., p. 92, pl. ii. figs. 1-3. 1893. ", : ,- T. Scott, Eleventh F. B. Rept., pt. iii. p. 201, pl. ii. figs. 21-35.

1904. ,, , G. O. Sars, l. c., vol. v. p. 17, pls, viii, ix.

Hab.-Frequent in material dredged off Musselburgh, Largo Bay, Aberdour Bay, and other places.

Genus (21) Neobradya, T. Scott, 1892.

35. Neobradya pectinifer, T. Scott.

1892. Neobradya pectinifer, T. Scott, Tenth F. B. Rept., pt. iii. p. 249, pl. xiii. figs. 19-32.

Hab.-Dredged off the north end of Inchkeith in November 1889, and also off St Monans in 1891. This species appears to have a fairly wide distribution, as it has been found in the Clyde by myself, and off the Isle of Man by the late I. C. Thompson of Liverpool.

Genus (22) Zosime, Boeck, 1872.

36. Zosime typica, Boeck.

1872. Zosime typica, Boeck, Chr. Vid.-Selsk. Forhandl. (1872, p. 46. 1880. ", ", G. S. Brady, Monogr. Brit. Copep.s vol. ii. p. 15, pl. xxxix. figs. 1-12.

Hab:-Taken off Musselburgh; frequent.

Genus (23) Ectinosoma, Boeck, 1864.

37. Ectinosoma Sarsi, Boeck.

1872. Ectinosoma Sarsi, Boeck, Chr. Vid.-Selsk. Forhandl. (1872), p. 45 .

1880. , , spinipes, G. S. Brady, l. c., vol. ii. p. 9, pl. xxxvi. figs. 1-10.

1904. „ Sarsi, G. O. Sars, Crust. of Norway, vol. v. p. 30, pl. xvi.

Hab.-Moderately common throughout the estuary. 
38. Ectinosoma melaniceps, Boeck.

1864. Ectinosoma melaniceps, Boeck, Chr. Vid.-Selsk. Forhandl. (1864), p. 30.

1880.,$\quad$, $\quad$ G. S. Brady, l. c., vol. ii. p. 11, pl. xl. figs. 17-20.

Hab.-Moderately common, especially among weeds in shallow inshore water.

39. Ectinosoma propinquum, T. and A. Scott.

1896. Ectinosoma propinquum, T. and A. Scott, Trans. Linn. Soc. Zool. (S. 2), vol. vi. p. 428, pl. xxxvi. figs. 19, 27, 46 et seq.

Hab.-Taken off Musselburgh, not very common; but as it is somewhat similar to $E$. Sarsi in size and general appearance, it is easily overlooked.

40. Ectinosoma Herdmani, T. and A. Scott.

1896. Ectinosoma Herdmani, T. and A. Scott, op. cit., p. 432, pl. xxxvi. figs. 16, 44 et seq.

Hab.-Moderately common in material dredged in Aberdour Bay and off Musselburgh; taken also sparingly off St Monans.

41. Ectinosoma Normani, 'T. and A. Scott.

1896. Ectinosoma Normani, T. and A. Scott, op. cit., p. 435, pl. xxxvi. figs. $21,29,39$ et seq.

1904. $\quad, \quad \quad, \quad$ G. O. Sars, op. cit., p. 35, pl, xix. fig. 2.

Hab.-Dredged sparingly off Burntisland.

42. Ectinosoma curticorne, Boeck.

1872. Ectinosoma curticorne, Boeck, Chr. Vid-Selsk. Forhandl. (1872), p. 45 .

1896. ", T. and A. Scott, op. cit., p. 430, pl. xxxvi. figs. 22 . 30, 34 et seq.

Hab. - Taken off Burntisland and Musselburgh, and a few other inland parts of the estuary.

43. Ectinosoma erythrops, G. S. Brady.

1880. Ectinosoma erythrops, Brady, Monogr. Brit. Copep., vol. ii. p. 12, pl. xxxvi. figs. 11-17.

1896. ,, ,, T. and A. Scott, op. cit., p. 431, pl. xxxvi. figs. 24, 31, 36 et seq.

$H a b .-$ Off St Monans; moderately rare. 
44. Ectinosoma gothiceps, Giesbrecht.

1882. Ectinosoma gothiceps, Giesb., Die frei-leb. Copep. d. Kieler Föhrde, p. 106, pl. i. figs. 3, 12 et seq.

1896. ", pygmoeum, T. and A. Scott, op. cit., p. 433 , pl. xxxvi. figs. 15, 41 et seq.

Hab.-Off St Monans; not common.

45. Ectinosoma armiferum, T. and A. Scott.

1896. Ectinosoma armiferum, T. and A. Scott, op. cit., p. 434, pl. xxxvi. figs. 20, 43 et seq.

Hab.-Obtained off the west side of May Island in moderately deep water; rare.

46. Ectinosoma tenuipes, T. and A. Scott.

1896. Ectinosoma tenuipes, T. and A. Scott, op. cit., p. 436, pl. xxxvi. figs. $25,32,35$ et seq.

Hab.-Dredged off St Monans; rare.

47. Ectinosoma longicorne, T. and A. Scott.

1896. Ectinosoma longicorne, T. Scott, op. cit., p. 439, pl. xxxvi. figs. 23,38 et seq.

Hab.-Dredged off St Monans ; rare.

48. Ectinosoma tenuireme, T. and A. Scott.

1896. Ectinosoma tenuireme, T. and A. Scott, op. cit., p. 439, pl. xxxvi. fig. 33 et seq.

Hab._-Dredged off St Monans ; rare.

49. Ectinosoma gracile, T. and A. Scott.

1896. Ectinosoma gracile, T. and A. Scott, op. cit., p. 429, pl. xxxvi. figs. 18, 37 et seq.

1904. ", , G. O. Sars, Crust. of Norway, vol. v. p. 39 , pl. xxii. fig. 1 .

Hab.-Dredged off St Monans; not very common. 
Genus (24) Microsetella, Brady and Robertson, 1873.

50. Microsetella norvegica (Boeck).

1864. Setella norvegica, Boeck, Chr. Vid.-Selsk. Forhandl. (1864), p. 281.

1873. Microsetella atlantica, Brady and Robertson, Ann. and Mag.

Nat. Hist. (4), vol. xii. p. 130, pl. ix. figs. 11-16.

1904. Microsetella norvegica, G. O. Sars, l. c., vol. v. p. 44, pl. xxiv.

Hab.-Taken near Inchkeith, with the surface tow-net, in November 1890, and subsequently in various parts of the estuary, sometimes in considerable numbers.

Genus (25) Pseudobradya, G. O. Sars, 1904.

51. Pseudobradya minor (T. and A. Scott).

1896. Bradya minor, T. and A. Scott, Trans. Linn. Soc. Zool. (S. 2), vol. vi. p. 425, pl. $\mathrm{xxxv}$. figs. 5, 9, 13, 21 et seq.

1904. Pseudobradya minor, G. O. Sars, l. c., vol. v. p. 41, pl. xxii. fig. 2 .

Hab.-Taken off St Monans and near Musselburgh, but apparently not very common.

52. Pseudobradya elegans (T. and A. Scott).

1896. Bradya elegans, T. and A. Scott, op. cit., vol. v. p. 422, pl. xxxv. figs. $4,10,15$ et seq.

$H a b$. - Taken sparingly in Largo Bay and off Musselburgh.

53. Pseudobradya hirsuta (T. and A. Scott).

1896. Bradya hirsuta, T. and A. Scott, op.cit., p. 423, pl. xxxv. figs. 2, 8, 17 et seq.

Hab.-Taken in Largo Bay in 1891, and afterwards in other parts of the estuary, but always very sparingly.

54. Pseudobradya similis (T. and A. Scott).

1896. Bradya similis, T. and A. Scott, op. cit., p. 424, pl. xxxv. figs. $3,7,16,27$ et seq.

1904. Pseudobradya similis, G. O. Sars, Crustacea of Norway, vol. v. p. 42 , pl. xxiii. fig. 2.

Hab. - The distribution of this species is similar to the last, but it is a smaller species, being little more than half the 
size. It resembles that species in having the furcal joints comparatively long and spreading.

55. Pseudobradya fusca (T. and A. Scott).

1896. Bradya fusca, T. and A. Scott, op. cit., p. 424, pl. xxxv. îgs. $6,12,18,20$ et seq.

Hab. - Taken very sparingly in Largo Bay. This is a moderately stout species, but the abdominal part of the body tapers more gradually towards the furcal joints than does some of the others.

Genus (26) Bradya, Boeck, 1872.

56. Bradya typica, Boeck.

1872. Bradya typica, Boeck, Chr. Vid.-Selsk. Forhandl. (1872), p. 47. 1904. " , , G. O. Sars, l. c., vol. v. p. 46, pl. xxV.

Hab.-Obtained off the west side of May Island, and in some other parts of the estuary; not very rare.

Genus (27) Harpacticus, M.-Edwards, 1838.

57. Harpacticus chelifer (O. F. Müller).

1785. Cyclops chelifer, O. F. Müller, Entomostraca. p. 114, pl. xix. figs. 1-3.

1904. Harpacticus chelifer, G. O. Sars, l. c., p. 49, pls. xxvii., xxviii.

Hab.-This species appears to be moderately common throughout the estuary, especially in the littoral and laminarian zones.

58. Harpacticus uniremis, Kröyer.

1838-40. Harpacticus uniremis, Kröyer, in Gaimard's Voy. en Scand., pl. xliii. fig. $1 a-p$.

1904. ", G. O. Sars, l. c., vol. v. p. 51, pl. xxix.

Hab.--Taken in the vicinity of Dunbar on 26th April 1894, but not previously recorded. 
59. Harpacticus flexus, Brady and Robertson.

1873. Harpacticus flexus, B. and R., Ann. and Mag. Nat. Hist. (4), vol. xii. p. 134, pl. ix. figs. 17-21.

1904. , , , G. O. Sars, l. c., vol. v. p. 53. pl. xxx. fig. 2.

Hab.-Obtained off St Monans, in Largo Bay, and off Musselburgh, but not very common.

60. Harpacticus obscurus, T. Scott.

1895. Harpacticus obscurus, T. Scott, Thirteenth F. B. Rept, pt. iii. p. 170 , pl. iv. figs. 4-12.

Hab.-Taken sparingly in an old quarry at Granton, open to the sea. This species has a superficial resemblance to the last, but is smaller, and the posterior foot-jaws (second maxillipedes) are different.

Genus (28) Tigriopus, Norman, 1868.

61. Tigriopus fulvus (Fischer).

1860. Harpacticus fulvus, Fischer, Abhandl. d. König. Bayer. Akad., vol. viii. p. 656, pl. i. figs. 30-33; pl. ii. figs. 34-39.

1904. Tigriopus fulvus, G. O. Sars, l. c., vol. v. p. 54, pls. xxxi., xxxii.

Hab.-Moderately common in pools about high-water mark on Cramond Island.

Genus (29) Zaus, Goodsir, 1845.

62. Zaus spinatus, Goodsir.

1845. Zaus spinatus, Goodsir, Ann. and Mag. Nat. Hist., vol. xvi. p. 326 , pl. xi. figs. 1-8.

1880. ,, ,, Brady, Monograph, vol. ii. p 153, pl. 1xvi. figs. 1-9.

1904. , , G. O. Sars, l. c., vol. v. p. 57, pl. xxxi.

Hab.-Frequent in dredged material collected off Musselburgh, in Largo Bay, and various other places.

63. Zaus Goodsiri, G. S. Brady.

1880. Zaus Goodsiri, Brady, Monograph, vol. ii. p. 156, pl. lxvi. figs. 10-13.

1904. ", ", G. O. Sars, l. c., vol. v. p. 59, pl. xxxv.

$H a b$.-Frequent in dredged material collected off St Monans, and also occasionally off the eist side of Inchkeith. 
Genus (30) Alteutha, Baird, 1845.

64. Alteutha interrupta (Goodsir).

1845. Sterope interrupta, Goodsir, Ann. and Mag. Nat. Hist., vol.

xvi. p. 326 , pl, xi. fig. 10 .

1863. Alteutha bopyroides, Claus, Die frei-lebenden Copepoden, p. 143, pl. xxii. figs. 10-17.

1904. , interrupta, G. O. Sars, l.c., vol. v. p. 62, pls. xxxvi. and xxxvii.

$H a b$-Frequent in tow-net gatherings collected amongst Larininaria, and also in inshore dredgings.

\section{Genus (31) Eupelte, Claus.}

65. Eupelte purpurocincta (Norman).

1868. Alteutha purpurocinctum, Norman, Brit. Assoc. Rept., p. 298.

1880. Peltidium depressum, Brady (not Baird), Monograph, vol. ii. p. 160, pl. 1xxii. figs. 1-5.

1904. Alteutha depressa, G. O. Sars, l. c., vol. v. p. 64 , pl. xxxviii.

Hab.-Taken off Musselburgh, off the north end of Inchkeith, and at other parts of the estuary, but not very common.

Genus (32) Tegastes, Norman, 1903.

66. Tegastes falcata, Norman.

1869. Amymone falcata, Norman, Brit. Assoc. Rept. for 1868, p. 296. 1880. " sphorica, Brady (not Claus), Brit. Copep., vol. ii. p. 28, pl. xlix. figs, 1-11.

1904. Tegastes falcatus, G. O. Sars, l. c., vol. v. p. 69 , pl. xli.

Hab.-Found sparingly throughout the estuary. This curious species was first recorded for the Forth in Part III. of the Sixth Annual Report of the Fishery Board for Scotland (1888). The A. sphorica of Claus (A. nigrans, T. and A. Scott) has not yet been observed in the Forth.

Genus (33) Porcellidium, Claus, 1860.

67. Porcellidium fimbriatum, Claus

1863. Porcellidium fimbriatum, Claus, Die frei-lebenden Copepoden, p. 140 , pl. xxii. fig. 1.

1904. " " $\quad$ G. O. Sars, l. c., vol. v. p. 76, pls. xliv., xlv.

Hab.-Obtained in Largo Bay on seaweed brought up 
with the dredge. This species frequents the fronds of Laminaria and other seaweeds, to which it can adhere very firmly; and from its colour and very flattened form it is, though not uncommon, easily missed unless the weed be carefully examined.

\section{Genus (34) Aspidiscus, Norman, 1868.}

68. Aspidiscus littoralis, G. O. Sars.

1880. Scutellidium fasciatum, G. S. Brady (not Norman), Monograph, vol. ii. p. 178, pl. lxviii. fig. 11; pl. lxix. figs. 1.9.

1904. Aspidiscus littoralis, G. O. Sars, l. c., vol. v. p. 79, pls. xlvi., xlvii.

Hab.-This species was obtained very sparingly in a shore gathering near the mouth of the estuary.

Genus (35) Tisbe, Lilljeborg, 1853.

69. Tisbe furcata (Baird).

1837. Cyclops furcatus, Baird, Mag. Zool. and Bot., vol. i. p. 330, pl. ix. figs. 26-28.

1850. Canthocamptus furcatus, idem, Brit. Entomostraca, p. 210, pl. xxv. figs. 1 and 2 ; pl. xxx. figs. 1-6.

1863. Tisbe furcata, Claus, Die frei-lebenden Copepoden, p. 116, pl. $x v$. figs. 1-10.

1880. Idya furcata, G. S. Brady, $l$, c., vol. ii. p. 172, pl, lxvii, figs. 1-11.

Hab.-Various parts of the estuary. Common, especially within the littoral and laminarian zones.

70. Tisbe gracilis (T. Scott).

1895. Idya gracilis, 'T. Scott, Thirteenth F. B. Rept., pt. iii. p. 171, pl. iv. figs. 13-21.

Hab.-In an old quarry at Granton, open to the sea; rare. Collected by hand-net near low-water.

Genus (36) Thalestris, Claus, 1863.

71. Thalestris longimana, Claus.

1863. Thalestris longimana, Claus, Die frei-lebenden Copepoden, p. 130, pl. xviii. figs. 1-11.

Hab.-In rock pools near high-water on Cramond Island; 
in the neighbourhood of Inchkeith; at Station VII. and other parts of the estuary; usually not very plentiful.

Genus (37) Parathalestris, G. O. Sars, 1905.

72. Parathalestris Clausi (Norman).

1869. Thalestris Clausi, Norman, Brit. Assoc. Report for 1868, p. 297.

1888. ", , G. S. Brady, Monograph vol. ii. p. 128, pl. 1xii. figs. 1-12.

$H a b$. - Largo Bay, washed from seaweed brought up by the dredge, frequent; dredged also in shallow water off Musselburgh.

\section{Parathalestris harpactoides (Claus).}

1863. Thalestris harpactoides, Claus, l. c., p. 133, pl. xix. figs. 2-12.

1905. Parathalestris harpacticoides, G. O. Sars, Crust. of Norway, vol. v p. 112, pl. lxvii.

Hab. - Dredged off St Monans in 1891, but only a few specimens were observed.

Genus (38) Phyllothalestris, G. O. Sars, 1905.

74. Phyllothalestris mysis (Claus).

1863. Thalestris mysis, Claus, l. c., p. 130, pl. xviii. figs. 12-16.

1880. „, , G. S. Brady, l. c., vol. ii. p. 121, pl. lviii. figs. 1.13.

Hab.-Firth of Forth, 1894,-_a fine species, very sparingly but widely distributed.

Genus (39) Halithalestris, G. O. Sars, 1905.

75. Halithalestris Croni (Kröyer).

1849. Harprcticus Croni, Kröyer, in Gaimard's Voyages en Scand., Zool., pl. xliii fig. 3 a-n.

1880. Thalestris serrulatus, G. S. Brady, l. c., vol. ii. p. 133, pl. lix. figs. 2-11.

$H a b$. -East of Inchkeith, several taken with surface townet in 1889; and in surface tow-net in June 1891 at Station IX. This appears to be a truly pelagic species, and widely distributed, but which only occasionally enters the Forth 
estuary. As the colour of these Copepods is bright red they are easily noticed, but the colour quickly disappears when they are preserved in alcohol.

Genus (40) Rhynchothalestris, G. O. Sars, 1905.

76. Rhynchothalestris rufocincta (Norman).

1880. Thalestris rufocincta, Norman (MS. name), in G. S. Brady, l. c., vol. ii. p. 125, pl. lvii. figs. 1-9.

1905. Rhynchothalestris rufocincta, G. O. Sars, Crust. of Norway, vol. v. p. 120, pls. Ixxiii., lxxiv.

Hab.-In pools between tide-marks about Joppa and Granton, 1887, frequent, and subsequently in various other parts of the estuary, but more common in the littoral zone than in deep water.

77. Rhynchothalestris helgolandica (Claus).

1863. Thalestris helgolandica, Claus, l. c., p. 131, pl. xvii. tigs. 12-21.

1880. „ " $\quad$ G. S. Brady, l. $c_{\text {., }}$ vol. ii. p. 123, pl. lxi. figs. 9-14.

1905. Rhynchothalestris helgolandica, G. O. Sars, Crust. of Norway, vol. v. p. 121, pl. lxxv.

Hab. - Washed from some seaweed obtained while dredging in Largo Bay in April 1891. Also obtained in dredged material collected off the north-east end of Inchkeith in May 1901.

Genus (41) Microthalestris, G. O. Sars, 1905.

78. Microthalestris forficula (Claus).

1863. Thalestris forficula, Claus, $l$. c., p. 131, pl. xvii. figs. 7-12.

1894. " forficuloides, T. and A. Scott, Ann. and Mag. Nat. Hist. (6), vol. xii. p. 142, pl. ix. figs. 4-9.

1905. Microthalestris forficula, G. O. Sars, l. c., vol. v. p. 123, pl. lxxvi.

Hab.-In pools near low-water between Leith and Portobello, not very common. The part of the shore where the specimens were chiefly obtained was opposite Seafield, where there is a good deal of mud.

VOL. XVI. 
Genus (42) Amenophia, Boeck, 1864.

79. Amenophia peltata, Boeck.

1864. Amenophia peltata, Boeck, Oversigt af Norges Copepoder, Chr. Vid.-Selsk. Forhandl., p. 45.

1880. Thalestris peltata, G. S. Brady, l. c., vol. ii. p. 138, pl. liii. figs. 11-19.

1895. " " $\quad$ T. and A. Scott, Ann. and Mag. Nat. Hist. (6), vol. xiv. p. 35 , pl. xv. figs. 11-15; pl. xvi. figs. 1-8.

Hab.-Dredged off Musselburgh; not common. The species differs from the typical Thalestris in the body being very depressed and in the structure of some of the appendages, as shown by the drawings in the works referred to.

\section{Genus (43) Westwoodia, Dana, 1855.}

80. Westwoodia nobilis (Baird).

1845. Arpacticus nobilis, Baird, Trans. Berw. Nat. Club, vol. ii. p. 155.

1880. Westwoodia nobitis, Brady, Brit. Copep., vol. ii. p. 141, pl. lxiii. figs. 1-13.

$H a b$. - Taken at Cramond Island in rock-pools between tide-marks, and in dredged material collected off Musselburgh in 3 to 4 fathoms; not common.

Genus (44) Pseudothalestris, ${ }^{1}$ Brady, 1883.

81. Pseudothalestris Andrewi (T. Scott).

1894. Pseudowestwoodia Andrewi, T. Scott, Twelfth F. B. Rept., pt. iii. p. 257, pl. ix. figs. 21-29.

Hab.-Dreiged off Burntisland in 3 to 4 fathoms water; frequent.

This group of Copepods have so close a general resemblance to Westwoodia, Dana, that I ascribed the first species to a new genus, Pseudowestwoodia, which recognised that resemblance, but afterwards I discovered that they were identical

${ }^{1}$ The genus Pseudothalestris is closely related to Westwoodia, Dana, but as it contains a group of species which differ distinctly in the structure of the first pair of thoracic feet, I prefer to retain it as a separate genus. 
with the genus Pseudothalestris, Brady, described by that author in his "Report on the Challenger C pepoda." I

82. Pseudothalestris pygmoea (T. and A. Scott).

1895. Pseudothalestris pygmoea, T. and A. Scort, Ann. and Mag. Nat. Hist. (6), vol. xv. p. 55, pl. vi. figs. 8-16 (January 1895).

Hab.-Dredged sparingly in the neighbourhood of Dunbar.

83. ${ }^{2}$ Pseudothalestris major ('T. and A. Scott).

(?) 1863. Westwoodia minuta, Claus, Die frei-lebenden Copepoden, p. 118, taf. xxi. figs. 10-14.

1895. Pseudowestwoodia major, T. and A. Scott, loc. cit., p. 56, pl. vi. figs. 17-2r.

Hab.-Drerged in the neighb urhood of Granton, and near Dunbar.

\section{Genus (45) Dactylopusia, Norman, 1903.3}

\section{Dactylopusia tisboides (Claus).}

1863. Dactylopus tisboides, Claus, Die frei-lelenden Copepoden, p. 127, pl. xvi. figs. 24-28.

Hab.-Shore-pools at Cramond Island; dredged off Musselburgh and other parts of the estuary; frequent in the littoral and laminarian zones.

\section{Dactylopusia neglecta, G. O. Sars.}

1880. Dactylopus tisboides, G. S. Brady (brackish-water var.), l. c., vol. ii. p. 108, pl. liv. figs. 1416.

1905. Dactylopusia neglecta, G. O. Sars, Crust. of Norway, vol. v. p. 127, pl. Ixxviii. fig. 2.

Hab.-This brackish-water form was observed in the lagoon at the mouth of the Cocklemill Burn (east end of Largo Bay).

${ }^{1}$ Cf. paper by 'T. and A. Scott in Ann. and Mag. Nat. Hist. (6), vol. Xv. p. 463 (June 1895).

${ }^{2}$ See remarks on this species and al-o on the genus in Part III. of the Twenty-fourth Annual Report of the Fishery Board for Scotland, at page 27\% (1906).

3 The name Dactylopus, Claus, being preoccupied by Gill for a genus of fishes, was by Canon Norman changed to Dactylopusia. 
86. Dactylopusia vulgaris, G. O. Sars.

1863. Dactylopus Strömi, Claus, l. c., p. 126, pl. xvi. figs. 1-6.

Hab.-Forth, west of Queensferry, washed from lumps of hardened mud; not very common. According to G. O. Sars, this is not the Canthocamptus Strömi, Baird, as Claus supposed it to be.

\section{Dactylopusia littoralis (T. Scott).}

1903. Dactylopus littoralis, T. Scott, Twenty-first F. B. Rept., pt. iii. p. 124, pl. iii. figs. $2-8$.

Hab.-Obtained in pools between tide-marks at Musselburgh in 1894, but not recorded till 1903. This seems to be a rare species.

\section{Dactylopusia finmarchica, T. Scott.}

1903. Dactylopus longirostris, Claus, var. finmarchicus, T. Scott, Ann. and Mag. Nat. Hist. (7), vol. xi. (Jan. 1903), p. 21, pl. ii. figs. $4-8$.

1903. ", mixctus, T. Scott, Twenty-first F. B. Rept., pt. iii. (pub. 20th July 1903), p. 126, pl. iii. figs. 9-16.

Hab. - This Dactylopusia was first described from specimens obtained in East Finmark, within the Arctic Circle, in a collection made by Canon Norman in the summer of 1890 . The species was also observed in a gathering collected in 1894 in the old quarry at Granton, where several other interesting Copepoda have been captured. This gathering was not thoroughly examined till 1903, when the Dactylopusia was by an oversight redescribed as a "new species," under the name of $D$. mixtus.

89. Dactylopusia debilis (Giesbrecht).

1882. Dactylopus debilis, Giesb., Frei-leb. Copep. d. Kieler Föhrde, p. 122, pl. i. figs. 7, 19 et seq.

1903. ", , T. Scott, Twenty-first F. B. Rept., pt. iii. p. 128, pl. v. figs. 20-31.

$H a b$. - This species occurred very sparingly in a gathering dredged off Musselburgh in 4 to 5 fathoms. 
90. Dactylopusia brevicornis (Claus).

1868. Dactylopus brevicornis, Claus, Die Copepoden-fauna von Nizza, p. 29, pl. iii. figs. 20-25.

1906. Dactylopusia brevicornis, 'T. Scott, Twenty-fourth F. B. Rept., pt. iii. p. 276, pl. xiv. figs. 10-18.

Hab.-Dredged in Largo Bay and in the old quarry at Granton; not common.

Genus (46) Dactylopodella, G. O. Sars, 1905.

91. Dactylopodella flavá (Claus).

1866. Dactylopus flavus, Claus, l. c., p. 28, pl. iii. figs. 13-16.

Hab.-Taken very sparingly with the dredge in Largo Bay and at Station III.

Genus (47) Idomene, Philippi, 1843.

92. Idomene forficata, Philippi.

1843. Idomene forficata, Philippi, Archiv. f. Naturgesch., 1843, p. 65, taf. iii. fig. 4.

1880. Dactylopus flavus, Brady, Monograph, vol. ii. p. 116, pl. lvi. figs. $1-11(\delta)$.

Hab. - I have occasionally dredged this species in the Forth estuary, but it was usually passed over as the male of Dactylopodella flava.

Genus (48) Idomenella, T. Scott, nov. gen., 1896.

This genus has a general resemblance to Idomene, Philippi. The antennules (anterior antennæ) short, six- or sevenjointed.

Posterior antennæ tolerably well developed, and composed of two joints.

Mandibles, with masticatory edge, moderately broad, and armed with several stout but irregular teeth. Mandiblepalp well developed, and furnished with two uniarticulate branches of moderate size, the outer one wanting the strong spines that appear to be characteristic of species belonging to Idomene. 
Maxillæ similar in structure to those of the genus mentioned.

The first and second maxillipeds are also similar to those of the same species.

The first pair of thoracic feet resemble those of Idomene, but the first joint of the inner branch is not nearly so robust, and the terminal setæ of the end joint are not so strongly clawed.

The second, third, and fourth pairs in the female are similar to those of Idomene, but the second pair in the male has the inner branch armed with a strong claw-like spine.

The fifth pair comparatively small, lamelliform, and the primary and secondary joints are sub-equal, and only moderately developed (cf. Twelfth Annual Report Fishery Board for Scotland, pt. iii. p. 255, pl. Ix. fig. 19, etc.).

Furcal joints short. One ovisac.

The differences that separate this genus from Idomene are comparatively small; but in the following two species, which I have ascribed to it, the armature of the mandible-pulp, and the structure of the inner branch of the first pair of thoracic feet, preclude them from a place in Philippi's genus.

\section{Idomenella rostrata, T. Scott.}

1893. Dactylopus rostratus, T. Scott, Eleventh F. B. Rept., pt. iii. p. 205, pl. iii. figs. 7-20.

Hab.-The specimens from which this species was described were obtained by carefully washing shells inhabited by the common hermit crab, Eupagurus, Bernhardus, which were dredged off the west side of Inchkeith.

\section{Idomenella coronata, T. Scott.}

1894. Dactylopus coronatus, T. Scott, Twelfth F. B. Rept., pt. iii. p. 255, pl. ix. figs. 12-20.

Hab.-Dredged near the Bass Rock and also in Largo Bay; not common. It has also been obtained very sparingly off Musselburgh, and at the north end of Inchkeith. 
Genus (49) Amphiascus, G. O. Sars, 1905.

95. Amphiascus minutus (Claus).

1863. Dactylopus minutus, Claus, Die frei-lebenden Copepoden, p. 126 , taf. xvi. figs. 14,15 .

1880. Brady, l. c., vol. ii. p. 119, pl. Ixvii. figs. 12-14.

Hab.-In dredged material from Largo Bay,-the only place within the estuary where this species has been noticed.

\section{Amphiascus Catharince, T. Scott. ${ }^{1}$}

1906. Amphiascus Catharince, T. Scott, Twenty-fourth F. B. Rept., pt. iii. p. 275, pl. xiv. figs. 10-18.

Hab.-Collected by hand-net in an old quarry at Granton, open to the tide, where many interesting forms have been obtained.

97. Amphiascus tenuiremis (Brady and Robertson).

1876. Dactylopus tenuiremis, B. and R., Brit. Assoc. Report for 1875 , p. 197.

1880. " " $\quad$ Brady, l. c., vol. ii. p. 115, pl. lvi. figs. 12-18.

Hab.-Dredged in Largo Bay, where it occurred very sparingly.

98. Amphiascus similis (Claus).

1866. Dactylopus simitis, Claus, Die Copepoden-fauna von Nizza, p. 25, taf. ii. figs. 29,30 .

1880. , , Brady, l. c., vol. ii. p. 110, pl. 1v. figs. 14-16.

Hab.-Dredged west-uff Queensferry, 17th November 1893 ; not common.

99. Amphiascus imus (G. S. Brady).

1872. Canthocamptus imus, Brady, Nat. Hist. Trans. Northumb. and Durham, vol. iv. p. 436, pl. xix. figs. 1-5.

1880. Stenhelia ima, idem, Monograph, vol. ii. p. 35, pl. xliii. figs. 1-14.

Hab.-Collected near Cramond and North Berwick in 1887, and near Inchkeith in 1901, but apparently not very common.

${ }^{1}$ Named in compliment to a friend of the author. 
Genus (50) Stenhelia, Boeck, 1864.

100. Stenhelia hispida, G. S. Brady.

1880. Stenhelia hispida, Brady, Monograph, vol. ii. p. 32, pl. xlii. figs. 1-14.

Hab.-This Copepod was observed sparingly in some material dredged off St Monans in 1893, and off North Berwick in July 1901.

101. Stenhelia hirsuta, I. C. Thompson.

1893. Stenhelia hirsuta, I. C. Thompson, Revised Rept. on the Copepoda of L-pool Bay, p. 20, pl. xxxi.

Hab.-Dredged off St Monans in 1893, and in the neighbourhood of Inchkeith in 1901. The female of this species carries two ovisacs instead of one, and thus differs from some of the other forms grouped under this genus.

102. Stenhelia dispar, T. and A. Scott.

1894. Stenhelia dispar, T. and A. Scott, Ann. and Mag. Nat. Hist. (6), vol, xii. p. 141, pl. viii. figs. 8-12.

Hab.-Dredged in the neighbourhood of the Bass Rock in 1893 ; apparently rare.

103. Stenhelia denticulata, I. C. Thompson.

1893. Stenhelia denticulata, I. C. Thompson, l. c., p. 20, pl. xxx. figs. 1-11.

Hab.-This very distinct species was dredged off St Monans in 1893, and it has also been obtained near Inchkeith, but appears to be somewhat rare in the estuary.

\section{Stenhelia reflexa, T. Scott.}

1895. Stenhelia reflexa, T. Scott, Thirteenth F. B. Rept., pt. iii. p. 166 , pl. iii. figs. $1-9$.

Hab.-This species was obtained in pools between tidemarks on the shore north-east of Dunbar in 1894. Only a few specimens were observed. It resembles Amphiascus imus in some respects, but differs in the structure of the anterior antennæ and of the first and fifth pairs of thoracic feet, as pointed out in the description. 
105. Stenhelia Blanchardi, T. and A. Scott.

1895. Stenhelia Blanchardi, T. and A. Scott, Ann, and Mag. Nat. Hist. (6), vol. xvi. p. 353, pl. xv. figs. 1-10.

Hab.-This tolerably distinct form was dredged off St Monans in 1896. The species was described from specimens obtained in some material dredged off Arisaig, Argyleshire, in 1892. Although this form appears to be widely distributed, it does not seem to be very common.

\section{Stenhelia pygmcea, A. M. Norman and T. Scott.}

1905. Stenhelia pygmoea, N. and S., Ann. and Mag. Nat. Hist. (7), vol. xv. p. 284.

1906. , , idem, Crust. of Devon and Cornwall, p. 142, pl. x. figs. 1-3; pl. xi. figs. 1, 2 et seq.

Hab._Station II., Forth, dredged 26th December 1894. This species, which is very small, appears to be widely distributed, as the type specimens were collected by the Rev. Canon Norman near Eddystone Lighthouse.

107. Stenhelia confusa, T. Scott.

1902. Stenhelia confusa, T. Scott, Twentieth F. B. Rept., pt. iii. p. 458, pl. xxii. figs. 17-25.

Hab.-Dredged at Station III., 7th June 1901. Apparently rare.

Genus (51) Ameira, Boeck, 1864.

108. Ameira longipes, Boeck.

1864. Ameira longipes, Boeck, Oversigt af Norges Copepoder, Chr. Vid.-Selsk. Forhandl., p. 55.

1880. ," , Brady, Monograph, vol. ii. p. 37, pl. liii. figs. 1-10.

Hab.-Dredged off St Monans and in other parts of the estuary, but not very common.

109. Ameira longicaudata, T. Scott.

1892. Ameira longicandata, T. Scott, Tenth F. B. Rept., pt. iii. p. 250, pl. ix. figs. 1-18.

$H a b .-$ Taken in various parts of the estuary. First noticed 
in material dredged off St Monans in 1891. This species appears to be moderately frequent in the Firth.

110. Ameira exilis, T. and A. Scott.

1894. Ameira exilis, T. and A. Scott, Ann. and Mag. Nat. Hist. (6), vol. xii. p. 139 , pl, viii. figs. $18 \cdot 20$; pl. ix. figs. 1-3.

1894. ", , $\quad$ T. Scott, Twelfth F. B. Rept., pt. iii. p. 242 , pl. ix. fig. 30 ; pl. x. figs. 1-12.

Hab.-This moderately large and distinct species was taken in shore-pools, near low-water, at Seafield, Leith; it was subsequently obtained at Musselburgh and near Dunbar, and in a somewhat similar situation.

\section{Ameira longiremis, T. Scott.}

1894. Ameira longiremis, T. Scott, Twelfth F. B. Rept., pt. iii. p. 241 , pl. v. figs. $29-32$; pl. vi. figs. $1-5$.

H"b.-This Ameira was taken very sparingly off St Monans in 1893, and this is the only record of it that I have for the Forth estuary, but it has since been obtained in the Clyde in Kilbrannan Sound.

112. Ameira exigua, T. Scott.

1894. Ameira exigua, T. Scott, op. cit., p. 243, pl. vi. figs. 15-23.

Hab.-Off St Monans, not very common. This species, like the last, has also been obtained in the Clyde.

113. Ameira tenuiremis, T. Scott.

1902. Ameira tenuiremis, T. Scott, Twentieth F. B. Rept., pt. iii. p. 459 , pl. xxiv. figs. $1-9$.

$H a b$. - Dredged off St Monans; rather rare.

114. Ameira propinqua, T. Scott.

1902. Ameira propinqua, T. Scott, op. cit., p. 460, pl. xxii. figs. 36-42; pl. xxiii. fig. 1; pl. xxiv. figs. 10-18.

Hab.-Dredged off St Monans; rare. 
115. Ameira pusilla, T. Scott.

1903. Ameira pusilla, T. Scott, Twenty-first F. B. Rept., pt. iii. p. 114, pl. v. figs. 1-10.

Hab.-This, which appears to be the smallest member of the genus, was taken sparingly, in shallow water, off Musselburgh; it has not, so far, been noticed anywhere else.

116. Ameira ambigua, T. Scott.

1903. Ameira ambigua, T. Scott, op. cit., p. 114, pl. v. figs. 11-19.

Hab.-Takeu off Musselburgh, in shallow water; apparently rare.

117. Ameira elegans, T. Scott.

1905. Ameira elegans, T. Scott, Twenty-third F. B. Rept., pt. iii. p. 144, pl. x. figs. 18, 19; pl. xi. figs. 1-9.

Hab.-Collected with hand-net in pools on the shore near low-water, north-west from Dunbar, and also in a shore gathering collected the same year near Musselburgh.

Genus (52) Robertsonia, G. S. Brady, 1880.

118. Robertsonia tenuis (G. S. Brady and Robertson).

1876. Ectinosoma tenue, Brady and Robertson, British Assoc. Rept. for 1875, p. 196.

1880. Robertsonia tenuis, Brady, Brit. Copep., vol. ii. p. 25, pl. xli. figs. 1-14.

Hab.-This species, which was first noticed in material dredged off North Berwick in 1887, appears to be sparingly distributed throughout the estuary.

Genus (53) Heteropsyllus, T. Scott, 1894.

119. Heteropsyllus curlicaudatus, T Scott.

1894. Heteropsyllus curticaudatus, T. Scott, Twelfth F. B. Rept., pt. iii. p. 252, pl. viii. figs. 27-34; pl. ix. fig. 1.

Hab.-Dredged off Musselburgh and near Aberdour; frequent. This species, though extensively distributed, having been observed in the Firth of Clyde and on the south 
coast of England, is readily passed over from its resemblance to more widely-known forms.

Genus (54) Delavalia, G. S. Brady, 1868.

120. Delavalia palustris, G. S. Brady.

1868. Delavalia palustris, Brady, Nat. Hist. Trans. Northumb. and Durham, vol, iii. p. 134, pl. v. figs. 10-15.

1880. „ " $\quad$ idem, Monograph, vol. ii. p. 43, pl. l. figs. 1-8.

Hab.-Taken in the neighbourhood of Culross, west of Queensferry, where the water is brackish, and also in brackishwater pools at the mouth of the Peffer Burn, Aberlady Bay, 1895.

121. Delavalia robusta, Brady and Robertson.

1875. Delavalia robusta, B. and B., Brit. Assoc. Rept. (1875), p. 196.

1880. ", " Brady, l. .c., vol. ii. p. 46, pl. li. figs. 15-21.

$H a b$.-In pools at the mouth of the Cocklemill Burn at the east end of Largo Bay, 16th August 1890; rare.

122. Delavalia reflexa, Brady and Robertson.

1875. Delavalia reflexa, B. and R., Brit. Assoc. Rept. (1875), p. 196.

1880. „ " Brady, l. c., vol. ii. p. 45, pl. li. figs. $1-14$.

Hab.-Dredged off Burntisland in November 1893; moderately rare.

Genus (55) Beatricella, ${ }^{1}$ T. Scott, 1905.

123. Beatricella mimica, T. Scott.

1897. Delavalia mimica, T. Scott, Fifteenth F. B. Rept., pt. iii. p. 150 , pl. i. figs. 1-9.

1905. Beatricella mimica, T. Scott, Ann. and Mag. Nat. Hist. (7), vol. xvi. p. 568.

Hab.-Dredged in the neighbourhood of Granton and off

1 This genus has been named in compliment to Miss Beatrice Sprague, daughter of Dr T. B. Sprague, Edinburgh, whose names are so frequently referred to in this Catalogue as successful students of Scottish fresh-water Crustacea. 
Musselburgh; not very rare. Dredged also off the northwest end of Inchkeith.

124. Beatricella aemula, T. Scott.

1893. Delavalia aemula, T. Scott, Eleventh F. B. Rept., pt. iii. p. 204, pl. iv. figs. 36-47.

1905. Beatricella cemula, T. Scott, Ann. and Mag. Nat. Hist. (7), vol. xvi. p. 569 (footnote).

Hab.-Dredged in Largo Bay, and subsequently in one or two other places.

Genus (56) Tachidius, Lilljeborg, 1853.

125. Tachidius discipes, Giesbrecht.

1853. Tachidius brevicornis, Lilljeborg (non Cyclops brevicornis, O. F. Müller, 1776), De Crust. ex ordinibus tribus, Clad. Ostrac. Copep., p. 196.

1880. " , Brady (non C. brevicornis, Müller), Monograph, vol. ii. p. 20, pl. xxxvii.

1881. , discipes, Giesb., Die frei-leb. Copep. der Kieler Föhrde, p. 108, pl. ii. fig. 4 ; pl. iv. figs. 25,28 et seq.

Hab.-Brackish-water pools at the mouth of the Cocklemill Burn at the east end of Largo Bay, 1890. This is a moderately common species in places such as that referred to.

\section{Tachidius littoralis, Poppe.}

1885. Tachidius littoralis, Poppe, Die frei-leb. Copep. des Jadebusens, Abhandl. d. nat. Ver. zu Bremen, vol. xi. p. 167, pl. vii. figs. 10-20.

1891. " crassicornis, T. Scott, Tenth F. B. Rept., pt. iii. p. 250, pl. viii. figs. 14-27.

Hab.-Dredged near Culross, west of Queensferry, 1892; not very rare. This, like $T$. discipes, is a brackish-water species, and appears to be generally distributed where the conditions are favourable. 
Genus (57) Pontopolites; T. Scott, 1894.

127. Pontopolites typicus, T. Scott.

1894. Pontopolites typicus, T. Scott, Twelfth F. B. Rept., pt. iii. p. 251, pl. viii. figs. 9-17.

Hab.-This species was described from specimens dredged off Musselburgh in 1893, and was at that time regarded as rare; subsequently, however, it was found to be moderately frequent in gatherings collected in shallow inshore waters. Like Tachidius discipes, this species has the fifth pair of thoracic feet composed each of a single lamelliform joint, but it differs very markedly in the structure of the other thoracic legs, so much so that it is with some hesitation I have placed it under this family.

Genus (58) Canthocamptus, Westwood, 1836.

128. Canthocamptus minutus (Müller).

1785. Cyclops minutus, O. F. Müller, Entomostraca, p. 101, pl. xvii. figs. 1-7.

1820. Monoculus staphylinus, Jurine, Hist. des Monocles, p. 74, pl. vii. figs. 1-19.

1880. Canthocamptus minutus, G. S. Brady, Monosraph, vol. ii. p. 48, pl. xliv. figs. 1-17.

Hab.-Moderately common, and generally distributed in lochs, ponds, ete., thronghout the district.

129. Canthocamptus horridus, S. Fischer.

1860. Canthocamptus horridus, Fischer, Akad. d. Wissensch., 8ten Bd. 3te Abth., p. 760, pl. ii. figs. 57-59, 59A.

1880. Canthocamptus northumbricus, Brady, $l_{\text {. }} e_{.}$, vol. ii. p. 57, pl. xlv. figs. 1-14.

Hab.-Duddingston Loch, 1892 ; Lochgelly Loch, Fifeshire, 19th August 1896. "Vicinity of Edinburgh" (Dr and Miss Sprague). This species does not appear to be very common in Scotland.

130. Canthocamptus gracilis, G. O. Sars.

1863. Canthocamptus gracilis, G. O. Sars, Vidensk, i Christiania Forhandl., 1862 (Aftr.), p. 22.

1897. , inornatus, T. Scott, Fifteenth F. B. Rept., pt. iii. p. 323, pl. ix. figs. 1-12.

1902. „ „ gracilis, Lillj., Synopsis Spec. hucusque in aquis dulc. Suec. observ. Fam. Harpactic., 1. 26, pl. ii. figs. 8-13.

Hab._Linlithgow Loch, Upper Elf Loch (near Edinburgh), 
Loch Achray (Trossachs); not very rare. It appears to be mure frequent in small lakes or ponds than in large bodies of water.

131. Canthocamptus lucidulus, Rehberg.

1863. Canthocamptus minutus, Claus, Die frei-lebenden Copep., p. 122, pl. xii. figs. 1-3 (name preoccupied by O. F. Mïller).

1880. " lucidulus, Rehberg, Beitrag. z. Kenntn., p. 551.

1895. " minutus, T. and A. Scott, Ann. Scot. Nat.

Hist. (Oct. 1895), p. 236, pl. iv. figs. 14-21.

Hab.-Duddingston Loch, Upper Elf Loch, Loch Leven, Loch Katrine, and others; Humbie Reservoir, near Winchburgh (Evans); moderately frequent, and generally distributed.

132. Canthocamptus hirticornis, T. Scott.

1895. Canthocamptus hirticornis, T. Scott, Thirteenth F. B. Rept., pt. iii. p. 251, pl. ix. figs. 13-26.

1902. " megalops, Lillj., l. c., p. 30, pl. ii. figs, 14-19.

1903. ," hirticornis, 'I'. Scott, Ann, and Mag. Nat.

Hist. (7), vol. xi. p. 188.

Hab.-In brackish-water pools at the mouth of the Cocklemill Burn at the east end of Largo Bay. This species is sometimes not uncommon where the conditions are favourable.

133. Canthocamptus palustris, G. S. Brady.

1880. Canthocamptus palustris, Brady, Monograph, vol. ii p. 53, pl. xxxix. figs, 13-23.

$1895 \quad$," $\quad$ var. elongatus, T. and A. Scott, Ann. and Mag. Nat. Hist. (6), vol. xv. p. 459, pl. xvi. tigs. 7-17.

Hab._In pools on May Island, 1889.

134. Canthocamptus parvus, T. and A. Scott.

1896. Canthocamptus parvus, T. and A. Scott, l. c. (6), vol, xviii. p. 6, pl. ii. figs. 14-22.

Hab.-Between tide-marks at Aberlady, and dredged in shallow water off Musselburgh; not common. 
135. Canthocamptus inconspicuus, T. Scott.

1900. Canthocamptus inconspicuus, T. Scott, Eighteenth F. B. Rept., pt. iii. p. 390, pl. xiv. figs. 1-8.

Hab.-Off Musselburgh, 1894; rare. This species was described from specimens found in the Moray Firth.

136. Canthocamptus Schmeili, Mrazek.

1893. Canthocamptus Schmeili, Mrazek, Zool. Jahrb. Sieb. Bd., p. 116, pl. vii. figs. 107-117.

1895. , , T. and A. Scott, Ann. Scot. Nat. Hist. (Oct. 1895), p. 234, pl. iv. figs. 1-13.

$H a b$. -Loch Leven, Kinross ; moderately frequent.

137. Canthocamptus crassus, G. O. Sars.

1863. Canthocamptus crassus, G. O. Sars, Chr. Vidensk.-Selsk. Forhandl., 1862 (Aftr.), p. 23.

1880. Attheyella spinosa, Brady, Monograph, vol. ii. p. 58, pl. xliii. figs. $15-18$; pl. xlvi. figs. 13-18.

Hab.-Frequent in lochs and ponds throughout the district.

Genus (59) Attheyella, G. S. Brady, 1880.

138. Attheyella pygmoea (G. O. Sars).

1863. Canthocamptus pygmoeus, G. O. Sars, op. cit., p. 21.

1880. Attheyella cryptorum, Brady, Monograph, vol. ii. p. 60 . pl. lii. figs. 1-18.

1893. , , , T. Scott, Eleventh F. B. Rept., pt. iii. p. 225, pl. vi. figs. 21-31.

Hab.-Moderately common, and generally distributed throughout the district.

139. Attheyella Zschokkei (Schmeil).

1893. Canthocamptus Zschokkei, Schmeil, Copep. des RhätikonGeberges, p. 31, pl. iii.

1893. Attheyella propinqua, T. Scott, Eleventh F. B. Rept., pt. iii. p. 227, pl. vii. figs. 1-11.

Hab.-Loch Leven, Duddingston Loch, Upper Elf Loch; not very rare, but easily overlooked. Ben Ledi, at about 2500 feet (Evans). 
140. Attheyella Duthiei, T. and A. Scott.

1895. Attheyella Duthiei, T. and A. Scott, Ann. and Mag. Nat. Hist. (6), vol. xviii. p. 4, pl. ii. figs. 1-13.

1902. Canthocamptus Duthiei, Lillj., Synops. sp. huc usque in aquis dulcibus Sueciae observ. Fam. Harpact., p. 41, pl. iii. figs. 5-10.

$H a b$.-Loch Leven is the only locality within the district where this species has been observed; it was obtained in gatherings collected by hand-net in 1890, 1897, and 1898 .

141. Attheyella cuspidata (Schmeil).

1893. Canthocamptus cuspidatus, Schmeil, op. cit., p. 36, pl. iv.

1897.

T. Scott, Fifteenth F. B. Rept., pt. iii. p. 323, pl. ix. figs. $21,22$.

Hab.-Loch Vennachar, Perthshire; not common. In spring at 2500 feet on Ben Ledi, September 1906 (W. Evans).

Genus (60) Nitocra, Boeck, 1864.

142. Nitocra tau, Giesbrecht.

1882. Nitocra tau, Giesb., Die frei-leben. Copep. der Kieler Foehrde, p. 117 , pl. i. figs. 9,13 ; pl. iii. fig 13 ; pl. iv. figs. $2,11,29$ et seq. .

$H a b$. - In pools overflowed by the tide at the mouth of the Cocklemill Burn at the east end of Largo Bay; not common.

Genus (61) Moraria, T. and A. Scott, 1893.

143. Moraria brevipes (G. O. Sars).

1863. Canthocamptus brevipes, G. O. Sars, Vidensk. i Christiania Forhandl., 1862 (Aftr.), p. 64.

1893. Moraria Anderson-Smithi, T. and A. Scott, Ann. and Mag.

Nat. Hist. (6), vol. vi. p. 213, pl. viii.

Hab.-Loch Vennachar, Loch Leven, Duddingston Loch, and the Upper Elf Loch are some of the places where this species has been obtained.

\section{Moraria Mrazeki, T. Scott.}

1893. Ophiocamptus brevipes, Mrazek (not Canthocamptus brevipes,

G. O. Sars), Zool. Jahrb. 7ter Bd., p. 116, pl. v. fig. 66; pl. vi. figs. 67-70.

1903. Moraria Mrazeki, T. Scott, Ann. and Mag. Nat. Hist. (7), vol. xi. p. 194.

Hab.-Loch Lubnaig, Loch Achray, Loch Vennachar. 
Genus (62) Maraenobiotus, Mrazek, 1893.

145. Maraenobiotus Vejdovskyi, Mrazek.

1893. Maraenobiotus Vejdovskyi, Mrazek, op. cit., p. 103, pl. iv. figs. 17-32; pl. v. figs. 33-37.

1896. ", „ T. and A. Scott, Ann. and Mag. Nat. Hist. (6), vol. xviii. p. 3, pl. i. figs. 13-21 ; pl. ii. fig. 23.

Hab.-The only locality within the district where I have found this species is Loch Vennachar.

Genus (63) Mesochra, Boeck, 1864.

146. Mesochra Lilljeborgi, Boeck.

1864. Mesochra Lilljeborgi, Boeck, Oversigt Norges Copepoder, p. 51.

1873. Paratachidius gracilis, Brady and Robertson, Ann. and Mag. Nat. Hist. (4), vol. xii. p. 131, pl. viii. figs. 8-16.

1880. Mesochra Lilljeborgi, Brady, Brit. Copep., vol. ii. p. 62, pl. xli. figs. 15-21; pl. xlvii. figs. 16-21.

$H a b .-F r e q u e n t$ in rock-pools near high-water, Cramond Island (1888); in pools at the mouth of the Cocklemill Burn, Largo Bay, 1890; and subsequently in other parts of the estuary.

147. Mesochra spinicaudata, T. and A. Scott.

1895. Mesochra spinicaudata, T. and A. Scott, Ann. and Mag. Nat. Hist. (6), vol. xv. p. 52, pl. v. figs. 12-25.

$H a b$.-Shore at Musselburgh, in pools near low-water; frequent.

148. Mesochra MacIntoshi, T. and A. Scott.

1895. Mesochra Mac-Intoshi, T. and A. Scott, l. c., p. 53, pl. vi. figs. 1-7.

Hab.-Shore at Musselburgh, in pools near low-water, not uncommon, 1894; and also in a gathering dredged off St Monans in July 1901.

149. Mesochra propinqua, T. Scott.

1896. Mesochra propinqua, T. Scott, Fourteenth F. B. Rept., pt. iii. p. 162, pl. iii. figs. 11-22.

Hab.-In pools between tide-marks at Aberlady Bay, collected by hand-net. 
Genus (64) Danielssenia, Boeck, 1872.

150. Danielssenia typica, Boeck.

1872. Danielssenia typica, Boeck, Nye Slœgter og arter af Saltvands Copepoder, Vid. Selsk. Forhandl., p. 55.

1876 Zosime spinulosa, Brady and Robertson, British Assoc. Rept. for 1875, p. 196.

1880. Jonesiella spinulosa, G. S. Brady, l. c., vol. ii. p. 41, pl. xlviii. figs 14-17; pl. xlix. figs. $14,15$.

Hab.-Largo Bay, 1890, and afterwards in other parts of the estuary, but nowhere very plentiful. The food in the stomachs of a sample of small plaice, Pleuronectes platessa, measuring off and on about 2 inches in length, sent from Annan on the Solway in 1900, consisted entirely of this species.

Genus (65) Thompsonula, T. Scott, 1905.

151. Thompsonula hyoence (I. C. Thompson).

1889. Jonesiella hyona, I. C. Thompson, Proc. Biol. Soc. L-pool, vol. viii. p. 193, pl. ix. figs. 1-10.

1893. ," ", T. Scott, Eleventh F. B. Rept., pt. iii. p. 202, pl. iii. figs. 1-6.

1905. Thompsonula hycence, T. Scott, Ann. and Mag. Nat. Hist. (7), vol. xvi. p. 570 .

Hab.-Dredged near the island of Fidra in February 1893, and later off Musselburgh; not common. The species appears to be widely distributed, but not very plentiful.

Genus (66) Laophonte, Philippi, 1840.

152. Laophonte lamellifera (Claus).

1863. Cleta lamellifera, Claus, Die frei-lebenden Copepoden, p. 123, pl. xv. figs. 21-25.

1880. Laophonte lamellifera, Brady, Monograph, vol. ii. p. 83, pl. lxxv. figs. 15-23.

Hab.-Dredged off Musselburgh; collected by hand-net in rock-pools between tide-marks at Cramond Island; and dredged at various other parts of the estuary; frequent. 
153. Laophonte curticauda, Boeck.

1864. Laophonte curticauda, Boeck, Oversigt af Norges Copepoder, p. 65.

1880.

Brady, l. c., vol. ii. p. 80 , pl. lxxiii. figs. 15-18; pl. lxxvi. figs. 1-9.

Hab.-Rock-pool on the shore, Cramond Island; dredged off North Berwick and in other parts of the estuary.

154. Laophonte longicaudata, Boeck.

1864. Laophonte longicaudata, Boeck, Oversigt af Norges Copepoder, p. 55.

1880.

Brady, l. c., vol. ii. p. 82, pl. lxxiv. figs. 12-15; pl. lxxvi. figs. 10-15.

Hab.-Dredged off St Monans in 1889; scarce.

155. Laophonte longiremis, T. Scott.

1905. Laophonte longiremis, T. Scott, Twenty-third F. B. Rept., pt. iii. p. 145, pl. xi. figs. 10-20.

$H a b$. - In an old quarry at Granton which is open to the sea, collected 25th August 1894. Apparently rare.

156. Laophonte thoracica, Boeck.

1864. Laophonte thoracica, Boeck, Oversigt af Norges Copepoder, p. 54.

1880. " " Brady, l. c., vol. ii. p. 76, pl. Ixxvii. figs. 1-8.

Hab.-Dredged in the neighbourhood of Inchkeith; off Musselburgh and other parts of the estuary; not very common.

157. Laophonte similis, Claus.

1866. Laophonte simitis, Olaus, Copepoden-Fauna von Nizza, p. 23, pl. v. figs. 13, 14 .

1880. " , , Brady, l.c., vol.ii. p. 78, pl. lxxv. figs. 1-14.

$H a b$. - In rock-pools between tide-marks at Cramond Island and in one or two other places, but not common. 


\section{Laophonte horrida (Norman).}

1876. Cleta horrida, Norman, Rept. of the "Valorous" Exped., Proc. Roy. Soc. London, 1876, p. 206.

1880. Laophonte horrida, Brady, l. c., vol. ii. p. 74, pl. lxxiv. figs. 1-12.

Hab.-Dredged off St Monans, and at Station V., to the west of May Island; not common. Dredged at the west end of Station VI., 22nd May 1901.

\section{Laophonte denticornis, T. Scott.}

1890. Laophonte serrata, T. Scott (not Claus), Eighth F. B. Rept., pt. iii. p. 318.

1894. " denticornis, idem, Twelfth F. B. Rept., pt. iii. p. 246, pl. vii. figs. 13-23.

Hab.-Dredged off St Monans, 1889; dredged off Musselburgh, 30th May 1891; and at Station III. (near the west end, in 5 fathoms), 23rd May 1901.

160. Laophonte inopinata, T. Scott.

1892. Laophonte inopinata, 'I'. Scott, Tenth F. B. Rept., pt. iii. p. 256, pl. xi. figs. 1-12.

$H a b$. - Off the west side of May Island. Several specimens were washed from a large "root" of sea-weed brought up in the trawl-net of the fishery cruiser "Garland" while at work in the neighbourhood of May Island in 1891; males and females carrying ovisacs were obtained. L. inopinata appears to be a rare species in the Forth.

\section{Laophonte intermedia, T. Scott.}

1895. Laophonte intermedia, T. Scott, Thirteenth F. B. Rept, pt. iii. p. 168, pl. iii. figs. 10-20.

Hab.-Shore at Musselburgh, in pools near low-water; dredged off the same place in 3 to 4 fathoms. Obtained also near Granton in an old quarry open to the sea. This is a distinct and easily recognised species.

\section{Laophonte littorale, T. and A. Scott.}

1893. Laophonte littorale, T. and A. Scott, Ann. and Mag. Nat. Hist. (6), vol. xii. p. 238, pl. xi. figs. 7-14.

Hab.-In brackish pools at the mouth of the Peffer Burn, near Aberlady. 
163. Laophonte gracilis, T. Scott.

1903. Laophonte gracilis, T. Scott, Twenty-first F. B. Rept., pt. iii. p. 118, pl. vi. figs. 6-12.

$H a b$.-Collected by hand-net near Granton, in an old quarry open to the sea.

164. Laophonte depressa, T. Scott.

1894. Laophonte depressa, T. Scott, Twelfth F. B. Rept., pt. iii. p. 245, pl. vi. figs. 24-31; pl. vii. figs. 1-3.

Hab.-Off St Monans and Musselburgh; very sparingly in dredged material from both places.

165. Laophonte hispida (Brady and Robertson).

1873. Asellopsis hispida, B. and R., Ann. and Mag. Nat. Hist. (4), vol. xii. p. 137, pl. ix. figs. 6-10.

1880. Laophonte hispida, Brady, Monograph, vol. ii. p. 85 , pl, lxxxi. figs. 1-11.

Hab.-Largo Bay, frequent; dredged also off Musselburgh and at various other parts of the estuary.

Genus (67) Harrietella, ${ }^{1}$ T. Scott, 1906.

166. Harrietella simulans, T. Scott.

1894. Laophonte simulans, T. Scott, Twelfth F. B. Rept., pt. iii. p. 248, pl. vii. figs. 24-32; pl. viii. fig. 1.

1906. Harrietella simulans, T. Scott, Ann. and Mag. Nat. Hist. (7), vol. xvii. p. 464, pl. xi. figs. 9, 10.

$H a b$.-Off West Wemyss and other places. The first specimens were obtained inside the valves of a dead Cyprina, among trawl refuse; but specimens were found afterwards to be moderately frequent in the crevices of partly decayed pieces of wood brought up in the dredge or trawl-net.

Genus (68) Laophontodes, T. Scott, 1894.

167. Laophontodes typicus, T. Scott.

1894. Laophontodes typicus, T. Scott, Twelfth F. B. Rept., pt. iii. p. 249, pl. viii. figs. $2-8$.

Hab.-Dredged at the north end of Inchkeith. This

1 This genus has been named in complement to Miss Harriet Richardson, M.A., D.Phil., Washington, U.S.A., author of A Monograph on the Isopods of North America. 
species, which is very small-scarcely $\frac{1}{60}$ of an inch in length-but quite distinct, is apparently very rare in the Firth of Forth. I have only met with it in the neighbourhood of Inchkeith; it seems, however, to have a fairly extensive distribution. Frequent in a gathering of small Crustacea from an old quarry at Granton collected in 1894.

Genus (69) Normanella, G. S. Brady, 1880.

168. Normanella dubia (Brady and Robertson).

1875. Laophonte dubia, B. and R., Brit. Assoc. Report for 1874, p. 196.

1880. Normanella dubia, Brady, Monograph, vol. ii, p. 87, pl. lxxviii. figs. 12-22.

Hab.-Dredged off Musselburgh ; not very rare, but easily overlooked.

169. Normanella attenuata, A. Scott.

1896. Normanella attenuata, A. Scott, Lancashire Sea-Fish Lab. Report for 1895, p. 47, pl. iv. figs. 8-20.

1902. ", ", T. Scott, Twentieth F. B. Rept., pt. iii. p. 464, pl. xxiii. figs. 2-4.

Hab.-Dredged off St Monans, in about 10 fathoms; rare. This species was described from specimens dredged off Spanish Head, Isle of Man, in 1895.

Genus (70) Cletodes, Brady, 1872.

170. Cletodes limicola, G. S. Brady.

1872. Cletodes limicola, Brady, Nat. Hist. Trans. Northumb, and Durham, vol. iv. p. 438, pl. xxi. figs. 10-17.

1880. " , idem, Monograph, vol. ii. p. 90, pl. lxxix. figs. 1-12.

Hab.-Dredged off North Berwick, off Musselburgh, and off the east side of Inchkeith, but not very common. It seems to be sparingly distributed throughout the estuary. 
171. Cletodes propinqua, Brady and Robertson.

1876. Cletodes propinqua, B. and R., Brit. Assoc. Report for 1875, p. 196.

1880. " , Brady, Monograph, vol. ii. p. 94, pl. lxxvii. figs. 9-17.

Hab.-In pools between tide-marks at Newhaven and Cramond Island; also dredged off Musselburgh; not very common.

172. Cletodes Sarsi, T. Scott.

1905. Cletodes Sarsi, T. Scott, Twenty-third F. B. Rept., pt. iii. p. 146, pl. xii. figs. 1-9.

Hab.-Firth of Forth, 1901 ; rare. This species was one of several in a bottle containing specimens from various parts of the estuary collected during 1901.

173. Cletodes curvirostris, T. Scott.

1894. Cletodes curvirostris, T. Scott, Twelfth F. B. Rept., pt. iii. p. 250 , pl. viii. figs. 18-26.

Hab.-Dredged in Largo Bay; dredged off the east side of Inchkeith, and a few other places; not very rare. In this species the rostrum is distinctly, though not strongly, recurved.

174. Cletodes irrasa, T. and A. Scott.

1894. Cletodes irrasa, T. and A. Scott, Ann. and Mag. Nat. Hist. (6), vol. xii. p. 141, pl. viii. figs. 8-12.

Hab. - Dredged in 1893 in the neighbourhood of the Bass Rock. It seems to be a rare species, as I have observed it on only one or two occasions since; but it has also been taken in the Clyde and the Moray Firth.

175. Cletodes tenuipes, T. Scott.

1897. Cletodes tenuipes, T. Scott, Fifteenth F. B. Rept., pt. iii. p. 170, pl. i. figs. 19-27.

Hab.-Off Musselburgh, dredged in 3 to 4 fathoms, in 1891 ; rare. The species was described from specimens 
taken in the Clyde in 1896. The Forth examples, which had been put aside when collected, were not identified till later.

176. Cletodes lata, T. Scott.

1892. Cletodes lata, T. Scott, Tenth F. B. Rept., pt. iii. p. 257, pl. $x$. figs. 10-18.

Hab.-Dredged off' St Monans, off Musselburgh, and other parts of the estuary; not common.

177. Cletodes similis, T. Scott.

1895. Cletodes similis, T. Scott, Thirteenth F. B. Rept., pt. iii. p. 168 , pl. iii. figs. 12-26; pl. iv. figs. 1-3.

$H a b$.- In the same gatherings with the last, as well as in pools between tide-marks, but always sparingly distributed. This species has a somewhat close resemblance to C. lata, and was at first regarded as a variety of it, but afterwards it was found to be quite distinct.

178. Cletodes longicaudata, Brady and Robertson.

1876. Cletodes longicaudata, B. and R., Brit. Assoc. Report for 1875, p. 196.

1880. ", , Brady, Monograph, vol. ii. p. 92, pl. lxxix. figs. 13-19.

1902. " , $\quad$ T. Scott, Twentieth F. B. Rept., pt. iii. p. 465, pl, xxiii. figs. 26-33.

Hab.-Dredged off St Monans in 1889; dredged off the east side of Inchkeith in June 1901; rare.

\section{Cletodes neglecta, T. Scott.}

1903. Cletodes neglecta, T. Scott, Twenty-first F. B. Rept., pt. iii. p. 120, pl. iv. figs. 20-31.

Hab.-Dredged in Aberlady Bay in 1895; not common. This species, which has been known to me for a considerable time, is somewhat intermediate between $C$. longicaudata and C. limicola; the furcal joints are about half as long as those of $C$. longicaudata; it thus differs from both the species named. Though collected in 1895, this is the first time it has beeu recorded for the Forth. The species was described from Moray Firth specimens. 
Genus (71) Itunella, Brady, 1894.

180. Itunella tenuiremis (T. Scott).

1893. Cletodes tenuiremis, T. Scott, Thirteenth F. B. Rept., pt. iii. p. 204, pl. iii. figs. 21-28.

1894. Itunella subsalsa, G. S. Brady, Nat. Hist. Trans. Northumb., Durh., and Newcastle-upon-Tyne, vol. xiii. p. 6, pl. i. (separate reprint).

Hab.-Dredged in the neighbourhood of Inchkeith in February 1893; and subsequently, but very sparingly, in several other places.

Genus (72) Fultonia, T. Scott, 1902.

181. Fultonia hirsuta, T. Scott.

1902. Fultonia hirsuta, T. Scott, Twentieth F. B. Rept., pt. iii. p. 466, pl. xxiii. figs. 5-12.

$H a b .-D r e d g e d$ very sparingly off St Monans, in 14 to 15 fathoms, on 22nd May 1901.

Genus (73) Enhydrosoma, Boeck, 1872.

182. Enhydrosoma curvatum (Brady and Robertson).

1876. Rhizothrix curvata, B. and R., Brit. Assoc. Report for 1875, p. 197.

1880. Enhydrosoma curvatum, Brady, Monograph, vol. ii. p. 98, pl. lxxxi. figs. 12-15; pl. lxxxii. figs. 11-19.

Hab.-Largo Bay and other parts of the estuary; moderately frequent.

183. Enhydrosoma gracile, T. Scott.

1903. Enhydrosoma gracile, T. Scott, Twenty-first F. B. Rept., pt. iii. p. 122, pl. ii. figs. $16-26$; pl. iii. fig. 1 .

$H a b$-Musselburgh, pools on the shore near low-water; moderately rare. This is a smaller species than $E$. curvatum.

Genus (74) Nannopus, G. S. Brady, 1880.

184. Nannopus palustris, G. S. Brady. 1880. Nannopus palustris, Brady, l. c., vol. ii. p. 101, pl. lxxvii. figs. 18-20.

1902. , , , T. Scott, Twentieth F. B. Rept., pt. iii. p. 466, pl. xxiii. figs. 13-25.

Hab.-Brackish-water pools at the mouth of the Cocklemill 
Burn at the east end of Largo Bay, also in shore-pools at Musselburgh, and in an old quarry near Granton which is open to the sea; not common.

Genus (75) Platychelipus, G. S. Brady, 1880.

185. Platychelipus littoralis, G. S. Brady.

1880. Platychelipus littoralis, Brady, l. c., vol. ii. p. 103, pl. 1xxix. figs. 20-23; pl. lxxx. figs. 15-19.

1893. , , ", T. Scott, Eleventh F. B. Rept., pt. iii. p. 205.

Hab.-Sparingly in a gathering of dredged material collected near Culross, and in an old quarry at Granton; dredged in shallow water off Musselburgh and in Aberlady Bay; scarce.

Genus (76) Cylindropsyllus, G. S. Brady, 1880.

186. Cylindropsyllus loevis, G. S. Brady.

1880. Cylindropsyllus lavis, Brady, l. c., vol. iii. p. 30, pl. Ixxxiv. figs. 1-8.

1892. „ ", T. Scott, Tenth F. B. Rept., pt. iii. p. 258, pl, xiii. figs. 1-18.

Hab.-Dredged off St Monans; frequent. I have found this species in other parts of the estuary, but much less frequently than in the "Fluke Hole" off St Monans.

187. Cylindropsyllus minor, T. Scott.

1892. Cylindropsyllus minor, T. Scott, op. cit., p. 260, pl. xi. figs. 17-24.

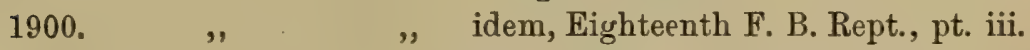
p. 349 , pl. xiv. figs. 23-32.

$H a b$.-Dredged off St Monans along with C. lavis, but not so common.

Genus (77) Leptopontia, T. Scott, 1902.

188. Leptopontia curvicauda, T. Scott.

1902. Leptopontia curvicauda, T. Scott, Twentieth F. B. Rept., pt. iii. p. 463, pl. xxii. figs. 26-35.

Hab.-Dredged off St Monans; not very common. 
Genus (78) Leptastacus, T. Scott, 1906.

189. Leptastacus macronyx, T. Scott.

1892. Tetragoniceps macronyx, T. Scott, Tenth F. B. Rept., pt. iii. p. 253, pl. x. figs. 19-28.

1906. Leptastacus macronyx, T. Scott, Ann. and Mag. Nat. Hist. (7), vol. xvii. p. 461 .

Hab.-Dredged off St Monans in 1891, and again in May 1901 ; not very common.

Genus (79) Evansula, T. Scott, nov. nom.

(Syn. Evansia, T. Scott, preoccupied for a genus of Spiders. ${ }^{1}$ )

190. Evansula incerta, T. Scott.

1892. Tetragoniceps incertus, T. Scott, Tenth F. B. Rept., pt. iii. p. 254, pl. xii. figs. 1-17.

1906. Evansia incerta, T. Scott, Ann. and Mag. Nat. Hist. (7), vol. $x$ vii. p. 461.

Hab.-Dredged off St Monans in 1891, and again in May 1901 ; not common.

191. Evansula pygmoea, T. Scutt.

1903. Tetragoniceps pygmoeus, T. Scott, Twenty-first F. B. Rept., pt. iii. p. 117, pl. iv. figs. 11-19.

1906. Evansia pygmoea, T. Scott, Ann. and Mag. Nat. Hist. (7), vol. xvii. p. 461.

Hab.-Collected near Musselburgh in 1894. This differs from the last by its smaller size, and in the structure of fifth thoracic feet and caudal joints.

${ }^{1}$ In the Annals and Magazine of Natural History for May 1906 I instituted a genus of the Copepoda under the name of Evansia, in compliment to William Evans, Edinburgh, a successful investigator in various departments of Scottish natural history. I find, however, that the name Evansia is preoccupied for a genus of spiders, described by the Rev. O. Pickard Cambridge in Proc. Dorset Nat. Hist. and Antiquarian Field Club, vol. xxi. p. 37, and I therefore adopt the modified form Evansula for the Copepod genus referred to. 
Genus (80) Tetragoniceps, G. S. Brady, 1880.

192. Tetragoniceps (?) maleolata, G. S. Brady.

1880. Tetragoniceps maleolata, Brady, Monograph, vol. ii. p. 66, pl. Ixxviii. figs. 1-11.

1892. ", (?). ", T. Scott, Tenth F. B. Rept., pt. iii. p. 252 , pl. viii. figs. 11,12 .

1900. " " idem, Eighteenth F. B. Rept., pt. iii. p. 391 , pl. xiv. figs. 9-17.

Hab.-Dredged off St Monans in 1892, apparently not very rare; and again on 22nd May 1901, several specimens were obtained. This form differs from the $T$. maleolata described by Dr Brady in the structure of fifth pair of thoracic feet, but is otherwise identical with it.

\section{Tetragoniceps brevicauda, 'T'. Scott.}

1900. Tetragoniceps brevicauda, T. Scott, Eighteenth F. B. Rept., pt. iii. p. 392, pl. xiv. figs. 18-22.

Hab.-This species was obtained somewhat sparingly in material dredged off St Monans in 1896, and again in 1901. It has a general resemblance to $T$. maleolata, but the furcal joints are distinctly shorter.

Genus (81) Phyllopodopsyllus, T. Scott, 1896.

194. Phyllopodopsyllus Bradyi, T. Scott.

1892. Tetragoniceps Bradyi, T. Scott, Tenth F. B. Rept., pt. iii. p. 253, pl. lix. figs. 19-32.

1906. Phyllopodopsyllus Bradyi, T. Scott, Ann. and Mag. Nat. Hist. (7), vol. xvii. p. 459.

Hab.-Dredged off St Monans in 1891, and again in 1901; apparently rare. This species and the next are easily distinguished by the large size and leaf-like form of the fifth pair of thoracic feet of the female.

Genus (82) Pteropsyllus, T. Scott, 1906.

195. Pteropsyllus consimilis, T. Scott.

1894. Tetragoniceps consimilis, T. Scott, Twelfth F. B. Rept., pt. iii. p. 244, pl. vii. figs. 4-12.

1906. Pteropsyllus consimilis, T. Scott, Ann. and Mag. Nat. Hist. (7), vol. xvii. p. 459 , pl. xi. figs. 7,8 .

Hab.-Dredged off St Monans; rare. This species is 
similar in its general appearance to T. Bradyi, but there are a few structural differences, one of the most important being the three-jointed inner branches of the first pair of thoracic feet: in T. Bradyi these branches are only two-jointed.

Genus (83) Leptopsyllus, T. Scott, 1894.

196. Leptopsyllus typicus, T. Scott.

1894. Leptopsyllus typicus, T. Scott, Twelfth F. B. Rept., pt. iii. p. 254, pl. ix. figs. 2-11.

$H a b$. - West of Queensferry, washed from lumps of hardened mud, which were composed for the most part of the agglutinated tubes of a species of Sabella, collected 25th January 1894 ; rare.

197. Leptopsyllus Robertsoni, T. and A. Scott.

1895. Leptopsyllus Robertsoni, T. and A. Scott, Ann. Scot. Nat. Hist. (January 1895), p. 30, pl. ii. figs. 1-14.

Hab.-In pools between tide-marks at Musselburgh, 20th August 1894; rare.

198. Leptopsyllus minor, T. and A. Scott.

1895. Leptopsyllus minor, T, and A. Scott, op. cit., p. 31, pl. ii. figs. 15-22.

$H a b$.-In pools between tide-marks at Musselburgh, taken at the same time as $L$. Robertsoni; moderately rare.

199. Leptopsyllus intermedius, T. and A. Scott.

1895. Leptopsyllus intermedius, T. and A. Scott, Ann. and Mag. Nat. Hist. (6), vol. xv. p. 51, pl. v. figs. 1-11.

Hab.-In pools between tide-marks at Musselburgh, in company with $L$. minor, $L$. Robertsoni, and a few of the other rare things mentioned elsewhere in this Catalogue. This species appeared to be rather more frequent than the other two.

Genus (84) Paramesochra, T. Scott, 1892.

200. Paramesochra dubia, T. Scott.

1892. Paramesochra dubia, T. Scott, Tenth F. B. Report, pt. iii. p. 252, pl. xii. figs. 18-32.

$H a b$. - Dredged off the west side of May Island in February 
1892, and off St Monans, in 13 fathoms, on 22nd May 1901. This curious form was also taken near Port Erin, Isle of Man, by the late I. C. Thompson of Liverpool.

\section{Division CYCLOPOIDA. \\ Family C Y C L O P I D $\mathbb{E}$.}

Genus (85) Oithona, Baird, 1843.

201. Oithona similis, Claus.

1866. Oithona similis, Claus, Copepoden-Fauna von Nizza, p. 14.

Hab.-Generally distributed in the Firth of Forth, and sometimes common. This is the form which, in my earlier papers on "Scottish Marine Copepoda," is recorded under the name of Oithona spinifrons, Boeck.

202. Oithona (?) setigera, Dana.

1849. Oithona setigera, Dana, U.S. Explor. Exped. [Amer. Jour. Sci. (2), vol. viii.].

1892. , ", Giesb., Fauna u. Flora Golfes v. Neapel ; Monogr. xix.-Pelag. Copep., p. 548, pl. xxxiv. figs. 3, 14, 41 et seq.

Hab.-Obtained in a bottom tow-net gathering collected east of Inchkeith in March 1891, and again on 22nd April 1901.

\section{Genus (86) Cyclopina, Claus.}

203. Cyclopina gracilis, Claus.

1863. Cyclopina gracitis, Claus, Die frei-lebenden Copepoden, p. 104, pl. x. figs, 9-15.

1878. " , Brady, Monograph, vol. i. p. 93, pl. xxiv. figs. $1-9$; vol. ii. pl. xci. figs. $10,11$.

1900. „, , Giesb., Mitth. über Copep., Mitth. a. d. Zool. Station z. Neapel, Bd. 14, p. 45.

Hab.-Generally, though somewhat sparingly, distributed in the Firth of Forth. I have taken it as far west as Charlestown, as well as near the outside limits of the estuary. 
204. Cyclopina littoralis (G. S. Brady).

1872. Cyclops littoralis, Brady, Nat. Hist. Trans. Northumb. and Durham, vol. iv. p. 429 , pl. xvii. figs. 9-14.

1878. Cyclopina littoralis, idem, Monograph, vol. i. p. 92, pl. xv. figs. 1-9.

1900. " , Giesb., Mitth. über Copep., Mitth. a. d. Zool. Station z. Neapel, Bd. 14, p. 43, pl. iii. figs. 1-13.

Hab.-Collected at Cramond Island in rock-pools ; dredged off Musselburgh and other parts of the estuary, especially in the littoral and laminarian zones; not uncommon.

205. Cyclopina elegans, T. Scott.

1894. Cyclopina elegans, T. Scott, Twelfth F. B. Rept., pt. iii. p. 237, pl. v. figs. 9-19.

1900. " , Giesb., Mitth. uiber Copep., Mitth. a. d. Zool. Station z. Neapel, Bd. 14, p. 44, pl. iii. figs. 14-22.

Hab. - This species has been taken off St Monans, but not comimon.

Genus (87) Pterinopsyllus, G. S. Brady, 1880.

(Syn. Lophophorus, Brady, 1878, a name preoccupied by Temminck in 1815 for a genus of Birds.)

206. Pterinopsyllus insignis, G. S. Brady.

1878. Lophophorus insignis, G. S. Brady, Monograph, vol. i. p. 122, pl. xiii. figs. 1-10; pl. xv. fig. 10 .

1880. Pterinopsyllus insignis, idem, ibidem, vol. iii. p. 23.

Hab.-This species was on several occasions observed moderately frequent in dredged material collected to the west of Queensferry, but appeared to be rare near the seaward limits of the estuary.

Genus (88) Cyclops, O. F. Müller, 1776.

The members of this genus are, with few exceptions, fresh-water or brackish-water species. Those recorded here 
may be conveniently arranged according to the number of joints in the antennules.

\section{(a) Species with Seventeen-Jointed Antennules.}

207. Cyclops strenuus, ${ }^{1}$ Fischer.

1851. Cyclops strenuns, Fischer, Bull. Soc. Imp. des Nat. Moscou, vol. xxiv, p. 419, taf, ix. figs. 12-21.

Hab.-Duddingston Loch, and most of the other lochs within the district, where it occurs nearly all the year round. Cyclops pulchellus and Cyclops abyssorum are other names by which the species is known.

208. Cyclops Leuckarti, Claus.

1857. Cyclops Leuckarti, Claus, Das gen. Cycl., Archiv. f. Naturg., Jahrg. xxiii. Bd. 1, p. 35, taf. ii. figs. 13,14 .

1897. " " $\quad$ T. Scott, Fifteenth F. B. Rept., pt. iii. p. 322, pl, ix. figs. 23-25.

Hab.-Loch Vennachar and Loch Voil, Perthshire; frequent. (See also note on this species in Appendix, p. 380.)

209. Cyclops bicuspidatus, Claus.

1857. Cyclops bicuspidatus, Claus, op. cit., p. 209, taf. xi. figs. 6 and 7.

1892. , , Schmeil, Deutschl, freileb. Süssw.-Copep. (Cyclopidæ), p. 75, taf. ii. figs. 1-3.

Hab.-Loch Achray (Trossachs), Loch Leven, Duddingston Loch, ponds on the Braid Hills, Edinburgh (April 1888), as well as in other lochs and ponds throughout the district, but usually not very common.

210. Cyclops vernalis, Fischer.

1853. Cyclops vernalis, Fischer, Bull. Soc. Imp. des Nat. Moscou, vol. xxvi. p. 90, taf. iii. figs. 1-5.

1891. ", elongatus, G. S. Brady, Revis. Brit. Cyclopidæ and Calanidx, p. 5, pl. i. figs. 1-5.

1892. ", vernalis, Schmeil, $\ell$. c., p. 88 , taf. ii. figs. $4-7$.

$H a b$. - The distribution of this species is somewhat similar

${ }^{1}$ Cyclops Ewarti, Brady, was described in the Sixth Annual Report of the Fishery Board for Scotland, p. 232, pl. viii. figs. 1-6, from specimens obtained above Queensferry. I am now inclined to consider this as representing a scarcely mature stage of $C$. strenuus, Fischer

VOL. XVI. 
to that of C. bicuspidatus. It has been obtained in several localities near Ediuburgh, i.e., Upper Elf Loch, Braids (Scott and Lindsay), and pond at Bonaly Golf Course (Dr and Miss Sprague). Ben Ledi, at 2500 feet (W. Evans).

211. Cyclops bisetosus, Rehberg.

1880. Cyclops bisetosus, Rehberg, Beitrag. z. Kenntnis der freileb. Süssw.-Copep., Abhand. d. Natur. Ver. zu Bremen, vol. vii. p. 533, pl. iv.

1901-1902. , , , Dr and Miss Sprague, Entom. of Midlothian, Trans. Edin. Field Natur., vol. iv. p. 255, pl. xxxi. figs. 18-22.

Hab.-Loch Achray, Loch Leven, and Duddingston Loch. Pond on House-o'-Hill Farm, Midlothian (Dr and Miss Sprague).

212. Cyclops viridis (Jurine).

1820. Monoculus quadricornis var. viridis, Jurine, Hist. des Monocles, p. 46, pl. iii. fig. 1.

1878. Cyclops gigas, G. S. Brady, Monograph, vol. i. p. 105, pl. xx. figs. 1-16.

Hab.-Loch Katrine, Loch Leven, Duddingston Loch, etc. Burntisland Reservoir and Loch a Chroin (Evans). A common and generally distributed species.

213. Cyclops signatus, Koch.

1820. Monoculus quadricornis fuscus, Jurine, l. c., p. 47, pl. ii. fig. 2. 1838. Cyclops signatus, Koch, Deutschlands Crustaceen, Myriapoden, und Arachniden, Heft. 21, fig. 8.

Hab.-Loch Katrine, Loch Achray, Loch Lubnaig, Perthshire. Ravelston Cottage Quarry, May 1900 (Dr and Miss Sprague). Side of river Teith, near Callander (W. Evans).

214. Cyclops annulicornis, Koch.

1820. Monoculus quadricornis albidus, Jurine, l. c., p. 44, pl. ii. figs. 10 and 11.

1838. Cyclops annulicornis, Koch, Deutschlands Crustaceen, Myriapoden, und Arachniden, Heft. 21, pl. vi.

Hab.-This is a common and generally distributed species throughout the entire area. 
(b) Species with Sixteen-Jointed Antennules.

215. Cyclops languidus, G. O. Sars.

1863. Cyclops languidus, G. O. Sars, Forhandl. Vidensk.-Selsk. i Christiania, p. 249.

1901-1902. - , . , , Dr and Miss Sprague, l. c., p. 255, pl. xxxi. figs. 1-7.

Hab.-This species, which was observed for the first time in Scotland in Loch Doon, in Ayrshire, ${ }^{1}$ was obtained in a pond near Tynehead, Midlothian, on 30th March 1901 (Dr and Miss Sprague).

(c) Species with Twelve-Jointed Antennules.

216. Cyclops serrulatus, Fischer.

1851. Cyclops serrulatus, Fischer, Bull. Soc. imp. des Natur. Moscou, vol. xxiv. (2) p. 423, pl. x. figs. 22, 23, 26-31.

Hab.-The Cyclops, generally referred to as "Cyclops serrulatus, Fischer," is common in lochs and ponds throughout the district. A form with short furcal joints, which appears to be the var. brachyurus of Cyclops varius, Lilljeborg, has been observed in Duddingston Loch and other places. Another form with the furcal joints elongated, and which may be the var. speratus of the same species, has also been observed, but they approximate so closely to the species described by Fischer, that I prefer, for the present, to regard them as varieties of that species.

217. Cyclops macrurus, G. O. Sars.

1863. Cyclops macrurus, G. O. Sars, l. c., p. 254.

1878. , , G. S. Brady, Monograph, vol. i. p. 111, pl. xxiv. figs. 1-5.

$H a b$.-Loch Vennachar, Loch Katrine, Loch Leven, Black Lnch near Loch Glow (Kinross-shire), and Loch Lubnaig.

${ }^{1}$ Cf. Seventeenth Annual Report of the Fishery Board for Scotland, pt. iii. p. 187 (1899). 
(d) Species with Eleven-Jointed Antennules.

218. Cyclops affinis, G. O. Sars.

1863. Cyclops affinis, G. O. Sars, l. c., p. 256.

1878. „ " „ Brady, Monograph, vol. i. p. 112, pl. xv. figs. 11-14; pl. xxiv. figs. 10-15.

Hab.-Raith Lake, near Kirkcaldy, Fifeshire, 1890. Elf Loch, and ponds in Penicuik grounds, 1900 (Dr and Miss Sprague). Humbie Reservoir, near Winchburgh, June 1906 (W. Evans).

219. Cyclops diaphanus, Fischer.

1853. Cyclops diaphanus, Fischer, l. c., vol. xxvi. p. 93, pl. iii. figs. 6-12.

1863. , , nanus, G. O. Sars, $l . c .$, p. 42.

1899. " , T. Scott, Seventeenth F. B. Rept., pt. iii. pp. 141, 172, 187.

1901. " diaphanus, Lillj., Kongl. Sv. Vet.-Handlingar, vol. xxxv. No. 4, p. 63, pl, iv. figs 13-15.

1901-1902. , nanus, Dr and Miss Sprague, Trans. Edin. Field Naturalists, vol. iv. p. 256, pl. xxxiA. figs. 7-12.

Hab.-This small species, first added to the British fauna in 1899, was obtained at Auchencorth Moss, Midlothian, in April 1901, by Dr and Miss Sprague.

(e) Species with Ten-Jointed Antennules.

220. Cyclops phaleratus, Koch.

1838. Cyclops phaleratus, Koch, Deutschl. Crustaceen, Heft 21, pl. ix.

1878. , ", Brady, Monograph, vol. i. p. 116, pl. xxiii. figs. 7-13.

Hab.-Duddingston Loch; Lochgelly Loch and Raith Lake, Fifeshire. Marl-pit, Davidson's Mains, near Edinburgh, June 1900 (Dr and Miss Sprague). This species also occurs in some material from the marl-pit collected by myself in May 1888. Teith at Callander (Evaus). 


\section{( $f$ ) Species with Eight-Jointed Antennules.}

221. Cyclops fimbriatus, Fischer.

1853. Cyclops fimbriatus, Fischer, l. c., p. 94, pl. iii. figs. 19-28 and 30 .

1878. " crassicornis, Brady, Monograph, vol. i. p. 118, pl. xxiii. figs. 1-6.

Hab.-Moderately common in ponds and lakes throughout the district.

Genus (89) Halicyclops, Norman, 1903.

\section{Halicyclops aequoreus (Fischer).}

1860. Cyclops oequoreus, Fischer, Abhandl. Math. Classe der Königl. Bayer. Akad. der Wiss. München, vol. viii.

(3) p. 654, pl. xx. figs. 26-29.

1878. ," , Brady, Monograph, vol. i. p. 119, pl. xix. figs. 8-10; pl. xxi. figs. 10-17.

Hab.-Cramond Island, in pools above high-tide mark, 1888; and in brackish-water pools at Aberlady in May 1895. Dr and Miss Sprague have also collected this species in a rock-pool on Cramond Island in July 1901.

\section{Genus (90) Eurgte, Philippi, 1843.}

\section{Euryte longicauda, Philippi.}

1843. Euryte longicauda, Philippi, Archiv. fur Naturh., Jahrg. 9, p. 63 , pl. iii. fig. $3, \alpha-d$.

1864. Thorellia brunnea, Boeck, Översigt Norges Copepoder, p. 26.

1872. ", " Brady, op. cit., vol. i. p. 95, pl. xvi. figs. 1-10.

Hab.-Moderately frequent throughout the estuary.

\section{Family LICHOMOLGID}

For further information concerning the Lichomolgidæ and Hersiliidæ, the reader is referred to Dr Canu's work, Les Copepodes du Boulonnais. 
Genus (91) Lichomolgus, Thorell, 1859.

224. Lichomolgus fucicolus, G. S. Brady.

1880. Lichomolgus fucicolus, Brady, Monograph, vol. iii. p. 41, pl. lxxxv. figs. 1-11.

Hab.-Firth of Forth; moderately rare. It has usually been obtained in shallow inshore water, amongst Laminaria, etc.

225. Lichomolgus furcillatus, Thorell.

1859. Lichomolgus furcillatus, Thorell, Om Krustaceer i Ascidier, p. 74 , taf. 13 , fig. 30 .

1880. " ", Brady, l. c., vol. iii. p. 49, pl. Jxxxviii. figs. 10-14.

Hab.-Collected near May Island and in the vicinity of Inchkeith, in the branchial cavity of large Ascidians; not common.

226. Lichomolgus hirsutipes, T. Scott.

1893. Lichomolgus hirsutipes, T. Scott, Eleventh F. B. Rept, pt. iii. p. 206, pl. iv. figs. 1-12.

Hab.-Taken with the dredge a short distance north of the Bass Rock, and off the North Craig; rather rare. On one occasion I found a considerable number of specimens adhering to the outside surface of the tubes of a large species of Sabella brought up on the hooks when line-fishing in 1895, in 15 to 20 fathoms, where the bottom consisted of mud. The Copepods were white, and therefore easily noticed on the mud-tubes made by the Annelids. ${ }^{1}$

227. Lichomolgus agilis (Leydig).

1853. Doridicola agilis, Leydig, Zeitschr. f. Wiss. Zool., Bd. 4, p. 377, taf. 14 .

1892. Lichomolgus agilis, Canu, Les Copep. du Boulonnais, p. 228, pl. xxii, figs. 1-14.

1892. , concinnus, T. Scott, Tenth F. B. Rept., pt. iii. p. 261, pl. ii. tigs. 25-33.

Hab.-Dredged off St Monans in 1891; rare. Taken also

1 Ann. Scot. Nat. Hist. (October 1895), p. 238. 
in the neighbourhood of Granton in 1893, on the branchial appendages of Doris (?) tuberculatus. ${ }^{1}$

Genus (92) Pseudanthessius, Claus, 1889.

228. Pseudanthessius gracilis, Claus.

1889. Pseudanthessius gracilis, Claus, Arb. Zool. Inst. Wien., t. viii. p. 344 , taf. 4 , figs. 1-7.

1893. , , , T. and A. Scott, Ann. and Mag. Nat. Hist. (6), vol. xii. p. 241, pl. xii. figs, 15-20.

Hab.-Dredged off Musselburgh in 1891; not common.

229. Pseudanthessius liber (Brady and Robertson).

1876. Lichomolgus liber, B. and R., Brit. Assoc. Rept. for 1875, p. 197.

1880. „, , Brady, Monograph, vol. iii. p. 44, pl. Ixxxvi. fig. 197.

$H a b$. - Dredged very sparingly off the north end of Inchkeith in 1894. Also dredged in the neighbourhood of Inchkeith on 23rd May, and off North Craig on 4th July 1901.

230. Pseudanthessius Thorelli (Brady and Robertson).

1876. Lichomolgus Thorelli, B. and R., Brit. Assoc. Rept. for 1875, p. 197.

1880. " , $\quad$ Brady, l. c., vol. iii. p. 47, pl. Ixxxviii. figs. 1-9.

Hab.-Dredged very sparingly off St Monans in 1893-1894. Also off the east side of Inchkeith on 23rd May 1901; rare.

231. Pseudanthessius Sauvagei, Canu.

1891. Pseudanthessius Sauvagei, Canu, Bull. Sci. France et Belgique, vol. xxiii. p. 481.

1894. „, " T. and A. Scott, Ann. and Mag. Nat. Hist. (6), vol, xii. p. 146.

Hab.-Dredged off St Monans in 1894; rare. During 1895 the fishery steamer "Garland" was engaged in some line-fishing experiments, when various things were brought up on the hooks, and the common Sea-Urchin, Echinus

1 Ann. and Mag. Nat. Hist. (6), vol, ii. (March 1893) p. 212, pl, vii. figs. 12-15. 
esculentus, among others. Some of these urchins I put into a bottle containing strong methylated spirit; after washing them in this spirit, an examination of the residue revealed a considerable number of specimens of this rare Copepod, and of little else.

Genus (93) Modiolicola, Aurivilius, 1883.

232. Modiolicola insignis, Aurivilius.

1883. Modiolicola insignis, Aur., Akad. Afhandl. Stockholm (1883), pp. 10 and 39 , taf. 2 , figs. $1-10$; taf. 4 , figs. 13-16.

1893. , , , T. Scott, Eleventh F. B. Rept., pt. iii. p. 207, pl. iv. figs. 13-24.

Hab.-Frequent in the shells of living "Horse Mussels," Mytilus modiolus. The species was obtained in most of the large mussels examined.

\section{Genus (94) Herrmannella, Canu, 1891.}

233. Herrmannella rostrata, Canu.

1891. Herrmannella rostrata, Canu, Bull. Sci. France et Belgique, t. xxiii. p. 480.

1892. , , , idem, Les Copep. du Boulonnais, p. 236, pl. xxiv. figs. 1-13.

1892. Lichomolgus agilis, T. and A. Scott, Ann. and Mag. Nat. Hist. (6), vol. x. p. 201, pl. xv. figs. 1-14.

Hab.-Frequent in the shells of living Cockles, Cardium edule, found in the cockle-beds at Cramond.

\section{Herrmannella maxima (I. C. Thompson).}

1893. Lichomolgus maximus, I. C. T., Trans. L-pool Biol. Soc., vol. vii. p. 34, pl. xxxv.

Hab.-Frequent in the shells of the Clam, Pecten opercularis, dredged on the clam-beds to the east of Inchkeith, but this Copepod was first observed by I. C. Thompson in the shell of living Pecten maximus, hence its name. This is not a true Lichomolgus, and as it agrees very closely with Hermannella, I place it meanwhile under that genus. 
235. Herrmannella arenicola (G. S. Brady).

1872. Boeckia arenicola, Brady, Nat. Hist. Trans. Northumb. and Durham, vol. iv. p. 430.

1880. Lichomolgus arenicolus, idem, Monograph, vol. iii. p. 46, pl. lxxxvii. figs, 1-7.

1892. ", , T. and A. Scott, Ann. Scot. Nat. Hist. (July 1892), p. 151, pl. vii. figs. 1-10.

Hab.-Dredged off St Monans in 1891; rare.

Genus (95) Sabelliphilus, M. Sars, 1862.

236. Sabelliphilus Sarsi, Claparède.

1870. Sabelliphilus Sarsi, Clap., Ann. des Sci. Nat. (5), vol. xiii. p. 6, pl. vii.

1887. Lichomolgus sabelloe, I. C. Thompson, Proc. L-pool Biol. Soc., vol. ii. p. 68 , pl. ii.

Hab.-Collected off St Monans, 7th July 1897, on the plumes of Sabella sp. (?S. pavonina); rare.

\section{Family CLA US I D 开.}

Genus (96) Hersiliodes, Canu, 1888.

237. Hersiliodes aberdonensis (T. and A. Scott).

1892. Lichomolgus aberdonensis, T. and A. Scott, Ann. Scot. Nat. Hist. (July 1892), p. 149, pl. vi. figs. 1-12.

Hab.-Dredged off the east side of Inchkeith on 23rd May 1901. The specimens from which the species was described in 1892 were obtained in a tow-net gathering collected in Aberdeen Bay.

238. Hersiliodes littoralis (T. Scott).

1892. Lichomolgus littoralis, T. Scott, Tenth F. B. Rept., pt. iii. p. 260 , pl. x. figs. 1-9.

Hab.-Collected in the neighbourhood of Culross in 1891. This appears to be a rare species in the Forth estuary, and is probably parasitic on some other invertebrate. 


\section{Family ASTEROCHERID E. $^{1}$}

Genus (97) Asterocheres, Boeck, 1859.

239. Asterocheres Lilljeborgi, Boeck.

1859. Asterocheres Lilljeborgi, Boeck, Forhandl. Vid.-Selsk. Chr. (1859), p. 6, pl. ii. figs. 1-11.

1880. Artotrogus Lilljeborgi, Brady, Monograph, vol. iii. p. 64.

Hab.-Firth of Forth; rare (cf. Giesbrecht, Asterocherido, pp. 70 and 73 ).

240. Asterocheres echinicola (Norman).

1869. Ascomyzon echinicola, Norman, Brit. Assoc. Rept. for 1868, p. 300 .

1880. Cyclopicera lata, Brady, l. c., vol. iii. p. 56, pl. lxxxix. fig. 12 ; pl. xc. figs. 11-14.

1893. ", ,, T. Scott, Eleventh F. B. Rept., pt. iii. p. 210, pl. iii. figs. 41 and 42 .

Hab.-Obtained, in 1889, by washing a number of Sponges in methylated spirit; the sponges were dredged in Aberlady Bay.

241. Asterocheres Boeckii (G. S. Brady).

1880. Artotrogus Boeckii, Brady, l. c., vol. iii. p. 60, pl. xei. figs. 1-9.

Hab.-Obtained at Granton Harbour in the water-passages of Sponges (Chalina oculata) growing on the walls of the pier; frequent.

1 In Fauna und Flora des Golfes von Neapel, Monograph 25, the Asterocheridæ, by Dr W. Giesbrecht (1899), the Forth species belonging to this family are for the most part described and figured by the author; and he also refers to their Scottish habitats in his remarks on the distribution of the various forms. The reader should consult this fine work, which contains a full synonymy and other information. 
Genus (98) Dermatomyzon, Claus, 1889.

242. Dermatomyzon nigripes (Brady and Robertson).

1876. Cyclopicera nigripes, B. and R., Brit. Assoc. Rept. for 1875, p. 197.

1880. , , , Brady, l. c., vol. iii. p. 54, pl. Ixxxix. figs. 1-11.

1892. ", ", T. Scott, Tenth F. B. Rept., pt. iii. p. 267.

Hab.-Collected in the neighbourhood of May Island in 1892. Dredged at Station I. on 30th August 1894, and subsequently captured at a few other places, but always very sparingly.

Genus (99) Rhynchomyzon, Giesbrecht, 1895.

243. Rhynchomyzon purpurocinctum (T. Scott).

1893 Cyclopicera purpurocincta, T. Scott, Eleventh F. B. Rept., pt. iii. p. 209, pl. iii. figs. 29-40.

Hab.-Dredged on the "Rath ground," to the north of the Bass Rock, on 20 th November 1889, and off the east side of Inchkeith on 23rd May 1901. This species, which appears to be rare in the Forth estuary, has a wide distribution, having been recorded not only from various parts of the British seas, but also from the Gulf of Naples.

Genus (100) Collocheres, Canu, 1893.

244. Collocheres gracilicauda (G. S. Brady).

1880. Cyclopicera gracilicauda, Brady, l. c., vol. iii. p. 58, pl. lxxxiii. figs. 1-10.

Hab.-Dredged off St Monans; rare.

Genus (101) Scottomyzon, Giesbrecht, 1897.

245. Scottomyzon gibberum (T. and A. Scott).

1894. Dermatomyzon gibberum, T. and A. Scott, Ann. and Mag. Nat. Hist. (6), vol xii. p. 144 , pl. ix. figs. 10-14.

1894. „ „, T. Scott, Twelfth F. B. Rept., pt. iii. p. 260, pl, x. figs. 26-34.

$H a b$. - Dredged in the neighbourhood of the Bass Rock in 
1893. In 1895 a number of specimens-adults and youngwere obtained by washing specimens of the common Starfish, Asterias rubens, in a bottle containing methylated spirit, and afterwards examining the residue. These specimens were of a brick-red colour on the back, but nearly white beneath. Their normal habitat is apparently on this kind of starfish.

Genus (102) Acontiophorus, Brady, 1880.

246. Acontiophorus scutatus (Brady and Robertson).

1873. Solenostoma scutatum, B. and R., Ann. and Mag. Nat. Hist. (4), vol. xii. p. 141.

1880. Acontiophorus scutatus, Brady, l. c., vol. iii. p. 69, pl. xc. figs. 1-10.

Hab.-Collected near Inchkeith in 1888. Off Musselburgh, dredged 30th May 1891, and subsequently collected in various other parts of the estuary; moderately frequent.

247. Acontiophorus ornatus (Brady and Robertson).

1876. Ascomyzon ornatum, B. and R., Brit. Assoc. Rept. for 1875 , p. 197.

1880. Acontiophorus armatus, Brady, l. c., vol. iii. p. 71, pl. lxxxvii. figs. 8-15.

Hab.-Dredged off North Craig on 4th July 1901; rare.

Genus (103) Scottocheres, Giesbrecht, 1897.

248. Scottocheres elongatus (T. and A. Scott).

1894. Acontiophorus elongatus, T. and A. Scott, Ann. and Mag. Nat.

Hist. (6), vol. xii. p. 145, pl. ix. figs. 15-20.

1898. Scottocheres elongatus, T. Scott, Sixteenth F. B. Rept., pt. iii. p. 278, pl. xiii. figs. 10-21.

Hab.-Obtained in 1893 in material dredged in the neighbourhood of the Bass Rock; frequent. 
Genus (104) Cribropontius, Giesbrecht, 189.9.

249. Cribropontius Normani (Brady and Robertson).

1876. Dyspontius Normani, B. and R., Brit. Assoc. Rept. for 1875, p. 197.

1880. Artotrogus Normani, Brady, l. c., vol. iii. p. 63, pl. xei. figs. 12-15; pl. xcii. fig. 10.

1897. Bradypontius Normani, T. Scott, Fifteenth F. B. Rept., pt. iii. p. 154, pl. ii. figs. 1 and 2 ; pl. iii. figs. 1-11.

$H a b .-T a k e n$ off the North Craig in material dredged on 4th July 1901; rare. This large and sometimes highlycoloured species appears to be rare in Firth of Forth.

Genus (105) Bradypontius, Giesbrecht, 1895.

250. Bradypontius magniceps (G. S. Brady).

1880. Artotrogus magniceps, Brady, $l$. c., vol. iii. p. 61, pl. xciii. figs. 1-9.

Hab.-Dredged west of Queensferry in 1888, and at the north-west end of Inchkeith on 23rd May 1901. Several fine specimens were obtained in material dredged off the North Craig on 4th July 1901, when a few of the females were found with ovisacs attached.

\section{Bradypontius papillatus (T. Scott).}

1888. Artotrogus papillatus, T. Scott, Sixth F. B. Rept., pt. iii. p. 232, pl. viii. figs. 7-12.

1899. Bradypontius chelifer, Giesbrecht, Fauna u. Flora Golfes v. Neapel, Monogr. 25 (Asterocheridæ), p. 88, pl. vi. figs. 15-25.

1899. Bradypontius papillatus, T. Scott, Seventeenth F. B. Rept., pt. iii. p. 262 , pl. xi. fig. 21 ; pl. xii. figs. 7-15

Hab.-Dredged in the neighbourhood of Inchkeith in 1888; apparently very rare. The specimen from which the description and drawings were prepared is the only one that has yet been observed in the Forth estuary. This specimen is, I think, certainly identical with the Bradypontius chelifer described by Dr Giesbrecht in his fine work on the Asterocheridæ. 
Genus (106) Dyspontius, Thorell, 1859.

\section{Dyspontius striatus, Thorell.}

1859. Dyspontius striatus, Thorell, Om Krustaceer i Acidier, p. 81, pl. xiv. fig. 22.

1880. , , , Brady, $l$. c., vol. iii. p. 66 , pl. xcii. figs. 1-12.

Hab.-Dredged at the north-west end of Inchkeith on 23rd May 1901. D. striatus has not previously been noticed within the limits of the Forth estuary, but it is a widely distributed species in our seas, though not very plentiful.

253. Dyspontius curticaudatus, T. Scott.

1905. Dyspontius curticaudatus, T. Scott, Twenty-third F. B. Rept., pt. iii. p. 148, pl. xiii. figs. 1-10.

$H a b$. - Dredged in the vicinity of Culross, a few miles above Queensferry; rare.

Genus (107) Parartotrogus, T. and A Scott, 1893

254. Parartotrogus Richardi, T. and A. Scott.

1893. Parartotrogus Richardi, T. and A. Scott, Ann. and Mag. Nat.

Hist. (6), vol. xi p. 211, pl. vii. figs. 1-11.

Hab.-Dredged near Fidra in 1889, but not recorded till 1893. It has subsequently been dredged off St Monans, in Largo Bay, and one or two other places, but nowhere very common.

\section{Family COR Y๋C $\mathbb{A} I \mathrm{D}$ Æ.}

Genus (108) Corycæus, Dana, 1845.

255. Corycous anglicus, Lubbock.

1857. Corycoeus anglicus, Lubb., Ann. and Mag. Nat. Hist. (2), vol. xx., pl. xi. figs. 16-19.

1880. ", , Brady, l. c., vol. iii p. 34, pl. lxxxi. figs. 16-19 et seq.

1900. " , , T. Scott, Eighteenth F. B. Rept., pt. iii. p. 397, pl. xiii. figs. 1-14.

Hab.-Dredged in the "Fluke Hole" off' St Monans; also washed from trawl refuse collected off West Wemyss, 
October 1895. This species appears to be of rare occurrence in the Forth estuary.

\section{Family N I C о т н О I D}

Genus (109) Nicothoë, Audouin and Milne-Edwards, 1826.

256. Nicothoë astaci, Aud. and M.-Edwards.

1826. Nicothoë astaci, Aud, and M.-Edwards, Ann. Sci. Nat., 1st ser., vol. ix. p. 345 , taf. 49 , figs. 1-9.

Hab.-Found adhering to the gills of a Lobster sent from Dunbar. I am indebted to my colleague, Dr H. C. Williamson, for the specimens of the Nicothoë. The distribution of the parasite appears to be co-extensive with that of its host.

Family ERGASILID E.

Genus (110) Bomolochus, Nordmann, 1832.

257. Bomolochus solece, Claus.

1864. Bomolochus solece, Claus, Zeitschrift für Wissenschaft, Zool., vol. xiv. p. 374 , pl. xxxv.

1893. ", , 'T. Scott, Eleventh F. B. Rept., pt. iii. p. 212, pl. v.

1902. " ", idem, Twentieth F. B. Rept., pt. iii. p. 288, pl. xiii. figs. 13-18.

Hab.-Firth of Forth; found on the back of a Black Sole, Solea vulgaris, and among dredged material, but in this case the specimens must, in some way, have been detached from the fish. Found in the nostrils of a Cod-fish by John Lindsay, Edinburgh. This Bomolochus has been obtained in the nasal fossæ of several kinds of fishes, but it is most frequent in those of the cod.

258. Bomolochus onosi, T. Scott.

1902. Bomolochus onosi, T. Scott, Twentieth F. B. Rept., pt. iii. p. 289, pl. xiii. tigs. 19-22.

Hab.-Firth of Forth, on the inside of the gill-covers of a Five-bearded Rockling, Onos mustelus (Linn.), captured in the estuary in May 1901. This Bomolochus has also been 
obtained on a specimen of the same kind of fish captured off Kinnaird Head in July 1901.

Genus (111) Thersitina, Norman, 1905.

(Syn. Thersites, Pagenstecher, 1861, preoccupied by Spence

Bate in 1857 for a genus of Amphipods.)

259. Thersitina gasterostei (Pagenstecher).

1861. Thersites gasterostei, Pagenst., Arch. f. Naturh,, vol. xvii. p. 118, pl. vi. figs. 1-9.

1899. Ergasilus gasterostei, Bassett-Smith, Proc. Zool. Soc. Lond. (April 1899), p. 444.

1900. Thersites gasterostei, T. Scott, Eighteenth F. B. Rept., pt. iii. p. 146, pl. v. figs 1-7.

$H a b .-O n$ the inside of the gill-covers of a Three-spined Stickleback, Gasterosteus aculeatus, captured in the river Forth, near Alloa, in February 1896. I have also taken this minute Copepod on the same species of fish captured in a small loch in Barra, Outer Hebrides; and in brackish-water ditches at Aberdeen, as well as on a Fifteen-spined Stickleback, Gasterosteus spinachia, captured in Loch Etive, on the west of Scotland.

\section{Division NOTODELPHYOIDA.}

Family NOTODELPHYDE.

Genus (112) Notodelphys, Allman, 1847.

260. Notodelphys Allmani, Thorell.

1860. Notodelphys Allmani, Thorell, Bidrag til Känned. Krust. Art. Slägtet Ascidia, p. 31, pl. i., and pl. ii. fig. 1.

1878. , , Brady, Monograph, vol. i. p. 126, pl. xxv. figs. 1-10.

Hab.-In the branchial cavity of Ascidians found adhering to the walls of Granton Harbour, and dredged in the neighbourhood of Inchkeith and elsewhere; moderately frequent.

261. Notodelphys agilis, Thorell.

1860. Notodelphys agilis, Thorell, l. c., p. 40, pl. iv. ; pl. v. fig. 6 .

1878.

, Brady, l.c., vol. i. p. 130, pl. xxvi.figs.1-10.

$H a b$. - In the branchial cavity of Ascidians found adhering to the pier at Granton. 
Family D O R O P Y GID 瓜.

Genus (113) Doropygus, Thorell, 1859.

262. Doropygus Normani, G. S. Brady.

1878. Doropygus Normani, Brady, l. c., vol. i. p. 136, pl. xxxii. figs. 1-14.

$H a b$. - In the branchial cavity of Ascidians dredged off Musselburgh, not uncommon, but apparently rare in other parts of the estuary.

263. (?) Doropygus porcicauda, G. S. Brady.

1878. Doropygus porcicauda, Brady, l. c., vol. i. p. 138, pl. xxvii. figs. $1-9$; pl. xxxiii. figs. 14-16.

1888. (?) , , " T. Scott, Sixth F. B. Rept., pt. iii. p. 239.

Hab.-A specimen that appeared to belong to this species was obtained among some material dredged near Inchkeith in 1887 , but as it is not now in my collection, I am unable to verify the record.

\section{Family A S CIDICOLID Æ.}

Genus (114) Ascidicola, Thorell, 1859.

264. Ascidicola rosea, Thorell.

1859. Ascidicola rosea, Thorell, l. c., p. 59, pl. ix.; pl. x. fig. 13.

1878. " ", Brady, l. $c_{\text {. }}$, vol. i. p. 145, pl. xxx. figs. 1-10.

Hab.-Obtained occasionally in the branchial chambers of Ascidians dredged in the neighbourhood of Inchkeith, off Musselburgh, and at a few other places in the estuary.

Genus (115) Aplostoma, Canu, 1886.

Syn. Enterocola, T. Scott, 1892 (not Enterocola, P. J. v. Beneden).

265. Aplostoma affinis, T. Scott, nov. nom.

1869. (?) Enterocola eruca, Norman, Last Report of Dredging among the Shetland Isles (Brit. Assoc. Rept. for 1868), p. 300 .

1892. ," ,, T. and A. Scott, Ann. and Mag. Nat. Hist. (6), vol. x. p. 203, figs. 1-11.

$H a b .-A$ few specimens of this curious species were VOL. XVI. 
obtained within the intestines of Ascidians found frequently adhering to the inside of the valves of dead mussels and other shells, dredged in various parts of the estuary. These specimens were mistakenly ascribed to Enterocola, van Beneden, but they more nearly resemble Aplostoma brevicauda, Canu. They differ, however, in some respects from that species, as shown by the description and drawings. I have therefore named the species as above.

\section{Family L A M I P P E I D Æ.}

Genus (116) Lamippe, Bruzelius, 1859.

266. Lamippe proteus, Claparède.

1867. Lamippe proteus, Claparède, Ann. des Sci. Nat., ser. 5, vol. viii. p. 23, pl. v.

1895. Alcyonicola fusiformis, T. and A. Scott, Ann. and Mag. Nat. Hist. (6), vol. xvi. p. 357, pl. xvi. figs. 10-14; pl. xvii. fig. 13.

1896. Lamippe(?) proteus, T. Scott, Fourteenth F. B. Rept., pt. iii. p. 164.

Hab.-On Alcyonium digitatum, dredged in various parts of the estuary; frequent. This curious species appears to live in the cells of the polyps. If an Alcyonium be broken into pieces, and the fragments washed in a bottle containing methylated spirit, numbers of the Lamippe will generally be found amongst the sediment.

267. Lamippe Forbesi, T. Scott.

1896. Lamippe sp., T. Scott, Fourteenth F. B. Rept., pt. iii. p. 164, pl. iv. figs. 9-13.

1901. Lamippe Forbesi, T. Scott, Nineteenth F. B. Rept., pt. iii. p. 256.

Hab. - This, which is a larger and apparently a much rarer species than $L$. proteus, has been found along with it on Alcyonium digitatum, dredged in the Firth of Forth. It has been observed on the same Alcyonium from other parts of the Scottish coast, and my son has also obtained it in Liverpool Bay. ${ }^{1}$

${ }_{1}$ Cf. Tenth Ann. Rept. Liverpool Marine Biological Committee, p. 21 (1897). 
Genus (117) Jeanella, T. Scott, F. B. Rept., 1904, pt. iii. p. 258.

(Syn. Platypsyllus, T. Scott, 1902, a name preoccupied

by Dr. Ritsema and Prof. Westwood in 1869.)

268. Jeanella minor, T. Scott.

1902. Platypsyllus minor, T. Scott, Twentieth F. B. Rept., pt. iii. p. 455 , pl. xxv. figs. $15,16$.

$H a b$. - This somewhat remarkable species was obtained in a gathering dredged in about 8 fathoms in the neighbourhood of the North Craig on 4th July 1901. Only a few specimens-all females, and one or two carrying ovisacswere observed.

\section{Division MONSTRILLOIDA.}

Family MONSTRILLID Æ.

Genus (118) Monstrilla, Dana, 1848.

269. Monstrilla anglica, Lubbock.

1857. Monstrilla anglica, Lubbock, Ann. and Mag. Nat. Hist. (2), vol. xx. p. 409, pl. x. figs. 7 and 8 .

1904. ", , T. Scott, Twenty-second F. B. Rept., pt. iii. p. 246 , pl. xiii. fig. 13 ; pl. xiv. figs. 12-14.

$H a b$. - Captured to the west of May Island, with a townet, on 26th July 1901, and also to the east of May Island on 20 th August 1903, but only females were observed in both gatherings.

270. Monstrilla longicornis, I. C. Thompson.

1890. Monstrilla longicornis, I. C. Thompson, Trans. L--pool Biol. Soc., vol. iv. p. 119, pl. iv. figs. 1, 2, and 4 ( $\delta$ ). 1892. ", longiremis, Giesb., Pelag. Copep. des Golfes v. Neapel, p. 589, pl. xlvi. figs. 10, 14, 22, 37, and $41(q)$.

1904. " longicornis, T. Scott, l. c., p. 244, pl. xiii. figs. 1-7 ( $\delta$ and $q$ ).

$H a b$. - This species was taken in the estuary very sparingly in $1890,1891,1893,1894$, and 1901. 
271. Monstrilla gracilicauda, Giesbrecht. 1892. Monstrilla gracilicauda, Giesb., l. c., p. 587, pl. xlvi. figs. 9, 16,18 et seq.

1904. ", , $\quad$ T. Scott, Twenty-second F. B. Rept., pt. iii. p. 245 , pl. xiii. figs. 8-10; pl. xiv. fig. 15 .

Hab. - Taken with tow-net above Queensferry, 26th June 1890 ; and off Musselburgh, 29th September 1892. Also captured east of May Island on 20th August 1903. All the specimens were females.

\section{Monstrilla dubia, T. Scott.}

1904. Monstrilla dubia, T. Scott, Twenty-second F. B. Rept., pt. iii. p. 247, pl. xiii. fig. 14; pl. xiv. figs. 16-18.

Hab.-This species was captured east of Inchkeith on 14th August 1891, and is apparently rare. It resembles Monstrilla Dance, Claparède, but that author shows only three setæ instead of four on each furcal joint; there are also one or two other differences.

Genus (119) Thaumaleus, Kröyer, 1849.

273. Thaumaleus rigidus (I. C. Thompson).

1888. Cymbasoma rigidum, I. C. Thompson, Jour. Linn. Soc. (Zool.), vol. $\mathrm{xx}$. p. 154, pl. xiii. figs. 1-4.

1892. Thaumaleus Claparèdei, Giesb., op. cit., p. 381, pl. xlvi. figs. $5,15,21,26$.

1904. ,, rigidus, T. Scott, Twenty-second F. B. Rept., pt. iii. p. 248 , pl. xiii. figs. $15-17$; pl. xiv. fig. 19.

Hab.-Captured off St Monans, by tow-net, on 6th September 1890 ; apparently rare.

\section{Division CALIGOIDA. \\ Family CALIGID 压.}

Genus (120) Caligus, O. F. Müller, 1785.

274. Caligus curtus, Müller.

1785. Caligus curtus, Müller, Entomostraca, p. 130, pl. xxi. fig. 1. 1850. " diaphanus, Baird, British Entomostraca, p. 269, pl. xxxii. fig. $1(\delta)$.

1850. " Mülleri, idem, $l$. c., p. 271 , pl. xxxii. figs. 4 and 5.

Hab.-Frequent on different kinds of fishes, especially 
Gadoids. The male Caligus, which Dr Baird describes and figures in his British Entomostraca under the name of Caligus diaphanus, Nordmann, is not Nordmann's species, but is the male of $C$. curtus, Müller.

\section{Caligus rapax, M.-Edwards.}

1840. Caligus rapax, M.-Edw., Hist. Nat. Crust., vol. iii. p. 453, pl. xxxviii. fig. 9.

$H a b$-Common on several kinds of fishes, especially Gadoids, as well as on flat fishes, Skate, Dogfishes, and others. From Short Sunfish, North Berwick, September 1905 (W. Evans). It is also frequently captured by tow-net in the open sea.

\section{Caligus minimus, Otto.}

1828. Caligus minimus, Otto, Beschreib. neuer Crust., Nov. Act. Acad. Cæs. Leop., vol. xiv. p. 354, pl. xxii.

1901. , , , A. Scott, Trans. L-pool Biol. Soc., vol. xv. p. 349 , pl. i. figs. 1-8.

Hab.-Found inside the throat of a Bass, Labrax lupus, Cuv. and Valenc., captured in the Forth, above Queensferry, in February 1903.

277. Caligus diaphanus, Nordmann.

1832. Catigus diaphanus, Nordm., Mikrog. Beiträge, vol. ii. p. 26.

1894. " isonyx, T. Scott, Twelfth F. B. Rept., pt. iii. p. 310 (not $C$. isonyx, Stp. and Lütk.).

1900. ", diaphanus, idem, Eighteenth F. B. Rept., pt. iii. p. 149 , pl. v. figs. $20-25$.

Hab.-Taken in the gill-cavity of Grey Gurnards, Trigla gurnardus, captured in the estuary; not very rare.

Genus (121) Pseudocaligus, A. Scott, 1900.

278. Pseudocaligus brevipedis (Bassett-Smith).

1896. Caligus brevipedis, Bassett-Smith, Ann. Nat. Hist. (6), vol. xviii. p. 11, pl. iii. fig. 1.

1901. Pseudocaligus brevipedis, A. Scott, Trans. L-pool Biol. Soc., vol. xv. p. 350 , pl. ii. figs. 1-6.

1902. ", " T. Scott, Twentieth F. B. Rept., pt. iii. p. 291.

Hab.-Found inside the throat of a Three-bearded Rockling, 
Onos tricirratus, captured at Dunbar in 1892. In this species the fourth pair of feet are more rudimentary than in typical Caligus.

Genus (122) Lepeophtheirus, Nordmann, 1832.

279. Lepeophtheirus pectoralis (O. F. Müller).

1776. Lerncea pectoratis, Müller, Zool. Dan. Prodr., vol. i. p. 41, pl. xxxiii. fig. 7 .

1850. Lepeophtheirus pectoralis, Baird, Brit. Entom., p. 275, pl. xxxii. fig. 10.

1900. " $\quad$ T. Scott, Eighteenth F. B. Rept., pt. iii. p. 150 , pl. v. figs. 26-31.

$H a b$. - Frequent under the pectoral fins of Plaice, Flounders, and Dabs.

280. Lepeophtheirus T'hompsoni, Baird.

1850. Lepeophtheirus Thompsoni, Baird, Brit. Entom., p. 278, pl. xxxiii. fig. 2.

1900. $\quad " \quad$ T. Scott, $l . c .$, p. 152, pl. v. figs. 43-45.

1900. ,, obscurus, idem, l.c., p. 153, pl. vi. figs. 16-19.

Hab.-Frequent on the gills of Turbot, Bothus maximus, captured off St Monans. The form I referred doubtfully to L. obscurus, Baird, appears to be identical with $L$. Thompsoni; it is sometimes common on the gills of the Brill, Bothus rhombus.

281. Lepeophtheirus pollachii, Bassett-Smith.

1896. Lepeophtheirus pollachii, Bassett-Smith, Ann. and Mag. Nat. Hist. (6), vol. xviii. p. 12, pl. iv. fig. 1.

1900. " ", T. Scott, op. cit., p. 153, pl. vi. figs. 9-15.

Hab. - Firth of Forth, on the gills of Lythe, Gadus pollachius, 8th February 1895; apparently not very rare. 


\section{Lepeophtheirus salmonis (Kröyer).}

1837. Caligus salmonis, Kröyer, Naturhist. Tidssk., vol. i., pl. vi. fig. $7 a-c$; vol. ii. (1838) pp. 13, 18.

1847. , Stromi, Baird, Trans. Berw. Naturalists Club.

1850. Lepeophtheirus Stromi, Baird, Brit. Entom., p. 274, pl. xxxii. figs. 8 and 9 .

1850. ", obscurus, idem, ibidem, p. 277, pl. xxxii. fig. 11.

Hab.-On Salmon caught in the salmon nets in Largo Bay and other parts of the estuary; frequent.

\section{Genus (123) Trebius, Kröyer, 1838.}

\section{Trebius caudatus, Kröyer.}

1838. Trebius caudatus, Kröyer, Naturhist. Tidsskr. (1838), R. i. B. ii. p. 30, pl. i. fig. 4.

1900. ,, , T. Scott, Eighteenth F. B. Rept., pt. iii. p. 155 , pl. vi. figs. 20-26.

$H a b$. - Taken on the backs of grey (or blue) Skates, Raia batis; moderately frequent.

\section{Genus (124) Cecrops, Leach, 1816.}

284. Cecrops Latreillei, Leach.

1816. Cecrops Latreillei, Leach, Encycl. Brit., Suppl. i., pl. xx. figs. 1-5.

1850. " , , Baird, Brit. Entom., p. 293, pl. xxxiv. fig. 1.

$H a b$. - Found on the gills of a Short Sunfish, captured in the estuary in October 1890 (A. Scott). Cecrops appears to be a common parasite on the gills of this species of Sunfish.

Genus (125) Orthagoriscola, Franz Poche, 1902.

(Syn. Lcemargus, Kröyer, 1838, name preoccupied for a genus of Fishes.)

285. Orthagoriscola muricata (Kröyer).

1850. Lomargus muricatus, Baird, Entomostraca, p. 295, pl. xxxiv. figs. 3 and 4.

$1900 . \quad$ „ , T. Scott, Eighteenth F. B. Rept., pt. iii. P. 158, pl. vi. figs. $39-42$.

1902. Orthagoriscola muricata, Franz Poche, Zool. Anzeiger, vol. xxvi. p. 15.

Hab.-On the same Sunfish with the Cecrops just recorded 
not, however, attached to the gills, but burrowing in hollows formed in the flesh of the fish, behind the anal fin (A. Scott). Off a Short Sunfish captured at North Berwick, 28th September 1905 (W. Evans). ${ }^{1}$ This appears to be a rarer species than the Cecrops.

Division LERN ÆOIDA.

Family L E R N \& I E.

Genus (126) Lernæa, Linné, 1767.

286. Lernoea branchialis, Linné.

1767. Lernoea branchialis, Linn., Systema Naturæ, ed. 12, vol. i. pt. ii. p. 1092.

1850. ", " Baird, Brit. Entom., p. 344, pl. xxxv. fig. 12.

$H a b$.-Frequent on the gills of Whitings and some other Gadoids.

Genus (127) Lernæenicus, Lesueur, 1824.

287. Lernocenicus spratta (Sowerby).

1806. Lernoea spratta, Sowerby, Brit. Miscell., vol. ii. p. 17, pl. 1xviii. 1900. Lernocenicus spratto, T. Scott, Eighteenth F. B. Rept., pt. iii. p. 161, pl. vii. figs. 7-10.

Hab.-On the eye of a Sprat, Clupea spratta, seen in one of the Leith Docks (J. Scott, August 1890)'. This Copepod is apparently seldom met with in the Firth of Forth, and this is the only record of its occurrence in the estuary known to me.

Genus (128) Hæmobaphes, Steenstrup and Lütken, 1861.

288. Howobaphes cyclopterinus (Fabricius).

1780. Lernoea cyclopterina, Fabr., Fauna Grönlandica, p. 337.

1900. Howobaphes cyclopterinus, T. Scott, Eighteenth F. B. Rept., pt. iii. p. 162, pl. vii. fig. 14 .

Hab. - Found on the gills of a Pogge, Agonus cataphractus, captured at Dunbar; and on a Butterfish, Pholis gunnellus, taken near Fidra in 1901.

1 Ann. Scot. Nat. Hist., 1906, p. 57. 
Family CHONDRACANTH ID E.

Genus (129) Oralien, Bassett-Smith, 1899.

289. Oralien asselinus (Linné).

1761. Lernoea asselina, Linn., Fauna Suecica, 2101.

1850. Lernentoma asselina, Baird, Brit. Entom., p. 329, pl. xxxv. fig. 4.

Hab.-Found on the gills of the Grey Gurnard, Trigla gurnardus; not uncommon. What appears to be the same species is also found on the gills of Plaice and one or two other fishes.

Genus (130) Chondracanthus, De la Roche, 1811.

290. Chondracanthus cornutas (O. F. Müller).

1776. Lernoea cornuta, Müll., Zool. Dan. Prodr., vol. i., pl. xxxiii. fig. 6.

1850. Lernentoma cornuta, Baird, l. c., p. 328, pl. xxxv. fig. 2.

Hab.-Found on the gills of Plaice, Pleuronectes platessa; not uncommon.

291. Chondracanthus clavatus, Bassett-Smith.

1896. Chondracanthus clavatus, Bassett-Smith, Ann. and Mag. Nat. Hist. (6), vol. xviii. p. 13, pl. v. fig. 6.

Hab.-Found on the gills of Lemon Dabs, Pleuronectes microcephalus, especially large fishes.

292. Chondracanthus flurce, Kröyer.

1864. Chondracanthus flurce, Kröyer, Naturh. Tidsskr., R. iii. B. ii. p. 323, pl. xiii. fig. 6 .

1900. " , T. Scott, Eighteenth F. B. Rept., pt. iii. p. 166, pl. vii. figs. $32-34$.

Hab.-Found on the gills of Long Rough Dabs, Drepanopsetta platessoides, captured in the estuary in 1891, and at Station III. in May 1901. 
293. Chondracanthus solea, Kröver.

1839. Chondracanthus solexe, Kröyer, Naturh. Tidsskr. (1838-39), p. 139 , pl. iii. fig. 4 .

Hab.-Found on the gills of the Black Sole, Solea vulgaris, captured in the estuary.

294. Chondracanthus depressus, T. Scott.

1905. Chondracanthus depressus, T. Scott, Twenty-third F. B. Rept., pt. iii. p. 114, pl. vi. figs. 7-13.

Hab.-Found on the gills of Dabs, Pleuronectes limanda, Linn., captured in the estuary; not very common.

\section{Chondracanthus merluccii (Holten).}

(?) 1802. Lernoea merluccii, Holten, Mem. Soc. Hist. Nat. Copenhagen, vol. v., pl. viii. fig. 2.

1837. Chondracanthus merluccii, Kröyer, Naturh. Tidsskr., vol. i. p. 278 , pl. iii. fig. $9 \alpha-\alpha$.

Hab.-Found in the gill-cavity of a Hake, Merluccius vulgaris, landed at Newhaven in February 1885. This is a moderately common parasite on the Hake; it may frequently be found clinging to the roof and sides of the mouth, and sometimes on the underside of the tongue, as well as inside the gill-covers.

296. Chondracanthus lophii, Johnston.

1836. Chondracanthus lophii, Johnston, Lond. Mag. Nat. Hist., p. 81, fig. 16.

1850. Lernentoma lophii, Baird, Brit. Entom., p. 330, pl. xxxv. fig. 3.

$H a b$-Common in the gill-chambers of the Angler-tish, Lophius piscatorius, captured in the estuary. This is one of the most common species of the Chondracanthi I have observed in the Firth of Forth.

\section{Chondracanthus zei, De la Roche.}

1811. Chondracanthus zei, De la Roche, Nouv. Bull. de Soc. Philom., vol. ii. p. 270, pl. ii. fig. 2 .

1850. Lernentoma zei, Baird, Brit. Entom. p. 327, pl. xxxv. fig. 1.

Hab.-Found on the gills of a John Dory, Zeus faber, captured in the estuary in 1891. 
Family LER N E O P O D I D A.

Genus (131) Charopinus, Kröyer, 1863.

\section{Charopinus Dalmanni (Retzius).}

1829. Lernoca Dalmanni, Retz., Kongl. Vetensk. Acad. Handl. för 1829 ; Frorieps Notizen, Bd. 29, N. 617, 1. 6.

1900. Charopinus Dalmanni, T. Scott, op. cit., p. 169, pl. viii. figs. 6-10.

Hab.-In the nasal fossæ of a large Grey Skate, Raia batis, captured near May Island in 1891. This curious parasite is frequent in the nasal fossæ of large skates, but seldom in small specimens.

Genus (132) Brachiella, Cuvier, 1817.

299. Brachiella insidiosa, Heller.

1865. Brachiella insidiosa, Heller, Reise der Novara, p. 239, pl. xxiv. fig. 1.

1896. , „, Bassett-Smith, Ann. aud Mag. Nat. Hist. (6), vol. xviii. p. 14, pl. vi. fig. 2.

Hab.-Found on the gills of a Hake captured in the estuary. This species is less common than the Chondracanthus merluccii, which is also found on the Hake.

300. Brachiella triglce, Claus.

1860. Brachiella triglce, Claus, Zur Morp. der Copepoden, pl. i. fig. 6.

1896. „, , Bassett-Snith, Jour. M. B. Assoc. Plymouth, p. 163.

Hab.-Found on Trigla lineata captured at Station VIII. in September 1897.

Genus (133) Anchorella, Cuvier, 1817.

301. Anchorella emarginata, Kröyer.

1837. Anchorella emarginata, Kröyer, Naturh. Tidsskr., R. i. B. i. p. 287 , pl. iii. fig. 7 .

1900. ", „, T. Scott, Eighteenth F. B. Rept., pt. iii. p. 176, pl. viii. figs. 49-51.

Hab.-Found on the gills of a Twaite Shad, Clupea finta, captured near Dunbar in February 1897. This appears to be a rare species. 
302. Anchorella rugosa, Kröyer.

1837. Anchorella rugosa, Kröyer, $l_{\text {. }}$., p. 294, pl. iii. fig. 6.

1850. , ", Baird, Brit. Entom., p. 338, pl. xxxv. fig. 8 .

Hab.-Found on gills and gill-covers and inside the throat of the Cat- or Wolf-fish, Anarrhichas lupus; not uncommon.

303. Anchorella uncinata (O. F. Müller)

1776. Lernoea uncinata, Miill., Zool. Dan. Prodr., vol. i., pl. xxxiii. fig. 2.

1850. Anchorella uncinata, Baird, t. c., p. 337, pl. xxxv. fig. 9.

Hab.-Found on the gills and inside the throat of Cod-fish, and probably on other Gadoids, not uncommon; but the Anchorelloe of these other Gadoids require further study, as they may not all belong to the same species.

304. Anchorella brevicola, M.-Edwards.

1840. Anchorella brevicola, M.-Edw., Hist. Nat. Crust., vol. iii. p. 418.

1901. ", , T. Scott, Nineteenth F. B. Rept., pt. iii. p. 135, pl. viii. figs. 11-16.

Hab.-Found on a Haddock. The parasite was attached on the under side of the fish, and near the anal fin. Only one specimen was observed.

I add here two other interesting parasitic Copepods, each of which represents a different family, viz.:-

Family HERPYLLOB I I D

Genus (134) Salenskya, Giard and Bonnier, 1893.

305. Salenskya tuberosa, Giard and Bonnier.

1893. Salenskya tuberosa, G. and B., Compt.-rend. de l'Acad. des Sci. (25th Sept. 1893).

1895. " " idem, Bull. Sci. de la France et de la Belgique, vol. xxv. p. 472, pl. xiii.

1902. ,, ", T. Scott, Twentieth F. B. Rept., pt. iii. p. 474, pl. xxv. figs. 17-22.

Hab.-Found in the marsupium of specimens of Ampelisca 
spinipes, Boeck; several examples of this species of Amphipod were infested with the parasite.

Family CHONIOSTOMATID Æ.

Genus (135) Aspidœcia, Giard and Bonnier, 1889.

306. Aspidcecia Normani, Giard and Bonnier.

1889. Aspidocia Normani, G. and B., Compt.-rend. de l'Acad. des Sci., 29th April.

1897. , , H. J. Hansen, The Choniostomatidæ, p. 187 , pl. xii. figs. $3 a, 3 b$.

1898. „, , T. Scott, Sixteenth F. B. Rept., pt. iii. p. 279 .

Hab. - Found adhering to a specimen both of Erythrops elegans (G. O. Sars) and Erythrops erythrophthalmus (Goës), captured in 1901 to the west of May Island; rare.

\section{THE THYROSTRACA OR CIRRIPEDIA.}

Scarcely any addition has been made to the number of Forth Crustacea belonging to this group since the publication of Leslie and Herdman's work on the Invertebrate Fauna of the Estuary.

\section{THORACICA.}

Family LEPA D I D Æ.

Genus (1) Lepas, Linné, 1767.

1. Lepas anatifera, Linné.

1767. Lepas anatifera, Linn., Systema Naturæ, ed. xii., vol. i. pt. ii. p. 1109.

1851. , , Darwin, Monogr. of the Cirripedia (The Lepadidæ), p. 73, pl. i. fig. 1.

Hab.-Attached to floating timber (Edin. Mus., Leslie and Herdman). Aberlady Bay, on piece of stranded timber, September 1893 (Evans). 
Genus (2) Conchoderma, Olfers, 1814.

2. Conchoderma aurita (Liuné).

1767. Lepas aurita, Linn., Systema Naturæ, ed. xii., vol. i. part ii. p. 1110.

1851. Conchoderma aurita, Darwin, l. c., p. 41, pl. iii. fig. 4.

Hab.-Attached to flnating timber (Edin. Mus., Leslie and Herdman).

3. Conchoderma virgata (Spengler).

1790. Lepas virgata, Spengler, Skrift. Naturh. Selbsk., vol. i., pl. vi. fig. 9.

1851. Conchoderma virgata, Darwin, l. c., p. 146, pl. iii. fig. 2; pl. ix. fig. 4.

$H a b$.-Attached to floating timber (Edin. Mus., Leslie and Herdman).

Family B A L A N I D Æ.

Genus (3) Balanus, Da Costa, 1778.

4. Balanus porcatus, Da Costa.

1778. Balanus porcatus, Da Costa, Hist. Nat. Test. Brit., p. 249.

1854. ," " Darwin, Monograph: Balanidæ, p. 256, pl. vi. figs. $4 a-4 e$.

Hab. - Not uncommon attached to stones, etc. (Leslie and Herdman).

5. Balanus crenatus, Bruguière.

1789. Balanus crenatus, Bruguière, Encycl. Method. (des vers).

1854. " ",$\quad$ Darwin, l. c., p. 261, pl. vi. figs. $6 a-6 g$.

Hab.-Shore at Portobello (Leslie and Herdman). East side of Inchkeith.

6. Balanus balanoides (Linué).

1767. Lepas balanoides, Linn., Systema Naturæ, vol. i. part ii. p. 1108.

1854. Balanus balanoides, Darwin, $l$. c., p. 267, pl. vii. figs. $2 a-2 d$.

$H a b$.-Common on rocks and stones between tide-marks, and also in deep water. 
7. Balrnus Hameri (Ascanius).

1767. Lepas Hameri, Ascan., Icones rerum Naturalium, Tab. 10.

1854. Balanus Hameri, Darwin, l. c., p. 277, pl. vii. figs. 5a-5c.

Hab.-Largo Bay, and off the west side of Inchkeith, single specimens, and occasionally a cluster attached to pieces of wood. ${ }^{1}$

Genus (4) Verruca, Schumacher, 1817.

8. Verruca Strömia (O. F. Müller).

1776. Lepas Strömia, Muill., Zool. Dan. Prodr., No. 3025.

1854. Verruca Strömia, Darwin, $l$. c., p. 518, pl. xxi. figs. $1 a-1 f$.

Hab.-Frequent on stones, dead shells, etc., brought up in the dredge.

\section{RHizOCEPHALA.}

Family SA C C ULIN Æ.

Genus (5) Sacculina, Thompson.

9. Sacculina carcini, Thompson.

Hab.-Attached to the abdomen of Shore Crabs, Carcinus monas, at Joppa (J. Anderson ${ }^{2}$ ); not very rare.

\section{Sacculina triangularis, J. Anderson.2}

Hab.-Firth of Forth (J. Anderson). Dunbar, attached to the abdomen of Cancer pagurus; rare (H. C. Williamson).

\section{Sacculina sp.}

Hab.-Attached to the abdomen of Portunus holsatus; this Sicculine has been observed very sparingly in different parts of the estuary.

${ }^{1}$ Balanus tintinnabulum (Linn.), from Leith Dock, in Leslie and Herdman's Iuvertebrate Fauna, is, as stated by these authors, "a foreign importation," and is not included with the others here.

${ }^{2}$ Cf. Proc. Roy. Phys. Soc., vol. ii. 
Genus (6) Peltogaster, Rathke.

12. Peltogaster paguri, Rathke.

$H a b$. - On the abdomen of the common Hermit (or Soldier) Crab, Eupagurus bernhardus (J. Anderson ${ }^{1}$ ). This Cirriped does not appear to be rare in the Forth estuary.

13. Peltogaster carcini (Anderson ${ }^{1}$ ).

Hab.-Firth of Forth, at Joppa (J. Anderson).

\section{A P P E N DIX.}

The following are some alterations in names, and additions to the species and localities, recorded in Part I. The total number of species enumerated in this Catalogue is now 794 .

Genus Eupagurus, Brandt, 1851 (p. 112).

The genus name Pagurus, Fabricius, 1793, has been restored, and included under it are the four species recorded in Part I. under Eupagurus. See Crustacea of Devon and Cornwall, by Canon A. M. Norman and T. Scott, p. 8 (1906).

Leptognathia Lilljeborgia, Stebbing (p. 132).

This species has been removed to another genus, viz., Tanaissus, Norman and Scott. See Crustacea of Devon and Cornwall, p. 34.

Genus Idothea, Fabricius (p. 135).

To the species recorded under Idothea, add Idothea granulosa, Rathke, Beiträge zur Fauna Norwegens, p. 23. In March $1906 \mathrm{Mr}$ William Evans obtained near Aberdour, Fife, two

${ }^{1}$ Cf. Proc. Roy. Phys. Soc., vol. ii. 
specimens of an Idothea that appear to me to belong to this species.

After Porcellio pictus (p. 140), add

The genus Metoponorthus, Budde-Lund, 1879, and the species M. pruinosus (Brandt). This Oniscoidan species has been captured (in April this year) at Slateford, near Edinburgh, by $\mathrm{Mr}$ William Evans, and is recorded by him in the Annals of Scottish Natural History for July 1906, p. 187.

Gammarus Duebeni, Lillj. (p. 163).

To the localities for this species add: Brackish pools, Luffness, near Aberlady, July 1906 (W. Evans).

Genus Jassa, Leach (p. 170).

The two species, Jassa falcata (Montagu) and Jassa pusilla (G. O. Sars), have been removed to the new genus Bruzeliella, Norman. See Crustacea of Devon and Cornwall, p. 92 .

Corophium grossipes, Linné (p. 172).

This species, under the name of Cancer grossipes, was described by Linné in 1767 in Systema Naturce, vol. i. part 2, p. 1055 ; but as Pallas had already, in 1766 , described under the name of Oniscus volutator, what appears to be the same form (cf. Miscellanea Zoologica, p. 102, pl. xiv. fig. 20), the name of the species should be Corophium volutator (Pallas), with $C$. grossipes as a synonym.

Protella phasma, Montagu (p. 174).

Professor Mayer in his work on the "Caprellidæ of the Bay of Naples," Caprelliden des Golfes von Neapel, Nachtrag, p. 19, refers this species to the new genus Pseudoprotella. VOL. XVI. 
Scapholeberis mucronata, O. F. Müller (p. 179).

To the localities given for this species add :- Side of river Teith, at Callander, September 1906 (W. Evans).

\section{Cyclops Leuckarti, Claus (Part II. p. 347).}

While this part of the Catalogue was passing through the press, Mr W. Evans sent me numerous specimens of a Cyclops which he had recently captured at the Falls of Leny, by holding a net so that some of the falling water would pass through it. The identification of the specimens somewhat puzzled me at first, but on carefully dissecting one or two of them, I found them to be the young of Cyclops Leuckarti; they were in the penultimate or antipenultimate stage; the segmentation of the body being slightly incomplete, while the antennules were furnished with only eleven articulations. Loch Voil, one of the two lochs from which the species is recorded, is situated to the north of Ben Ledi, and the river Balvaig carries its overflow water to Loch Lubnaig; this, in turn, is the source of the river Leny. It is probable, therefore, that Cyclops Leuckarti occurs in this loch also, though I have not as yet found it there. The loch and river were in flood when Mr Evans visited the Falls, and the specimens were very likely carried from the loch by the increased force of the current.

The normal habitat of Cyclops, as of most fresh-water Entomostraca, is in the comparatively still waters of lochs, ponds, and other similar places, and their presence in the rapid currents of rivers is usually accidental. The occurrence of this Cyclops in the Leny is, therefore, of interest from its bearing on the question of distribution, and as showing that the species is probably present in Loch Lubnaig as well as in the other two lochs from which it has been recorded. 
Additional Note.-As the second part of this Catalogue was ready to go to press, I received a copy of an important work on the Amphipoda Gammaridea by the Rev. T. R. R. Stebbing, M.A., F.R.S., etc. This work, which has just been published, forms the twenty-first of the series of Monographs that are being issued under the general title Das Tierreich. The Amphipoda are here divided into three legions, viz., the Gammaridea, the Hyperiidea, and the Caprellidea, and it is the first that forms the subject of Mr Stebbing's volume. The number of known species belonging to the Gammaridea as given in it is 1333 . Of these, 1076 are "accepted species," while the remaining 257 are regarded as doubtful. Their classification differs to some extent from that of the Monograph by G. O. Sars. There are also a considerable number of changes in the nomenclature, and I take the opportunity to indicate the more important of these, so far as they concern the species recorded in this Catalogue.

In the work referred to-Talitrus locusta (Pall.) becomes T. saltator (Mont.), and Orchestia littorea (Mont.) O. gammarellus (Pall.), while Hyale Nilssoni (Rathke) takes the name of H. Prevostii (M.-E.). The genus Callisoma, A. Costa, becomes Scopelocheirus, Bate, and Orchomene humilis (A. Costa) becomes O. Batei, O. Sars. Tryphosella, Bonnier, is replaced by Tryphosa, Boeck, but Tryphosa nana (Kröy.) becomes Orchomenella nanus (Kröy.). Anonyx nugax (Phipps) becomes A. lagena, Kröy., and the genus Tmetonyx, Stebb., replaces Hoplonyx, O. Sars. Phoxocephalus Fultoni, T. Scott, becomes Paraphoxus Fultoni (T. S.), Harpinia neglecta, $\mathrm{O}$. Sars, becomes $H$. antennaria, Meinart, and Amphilochoides serratipes (Norm.) resumes the name of $A$. Boeckii, O. Sars. Metopa Bruzelii (Göes) becomes M. sinuata, O. Sars, and $M$. robusta is restored to its place in the same genus. Synchelidium brevicarpum (B. \& W.) becomes S. haplocheles (Grube), and Halimedon parvimanus (B. \& W.) Westwoodilla crecula, Bate. The genus Paramphithoë, Bruz., becomes Neopleustes, Stebb., and Paratylus, O. Sars, Nototropis, A. Costa; $N$. uncinatus, $\mathrm{O}$. Sars, is also made a synonym to $N$. falcatus (Metzg.). Iphimedia minuta, O. Sars, becomes Panoploca minuta (O. Sars). The genus Amathilla, Bate, is replaced by Gammarella, Herbst, and Gammaropsis, Lillj., by Eurystheues, Bate, while Gammaropsis nana, O. Sars, becomes E. palmatus (Stebb. and Rob.). Podoceropsis excavata (Bate) becomes P. nitida, Stimps., Jassa Herdmani (A. O. Walker) J. dentex (Czern.), and Jassa pelagica, Leach, Parajassa pelagica (Leach). Erichthonius abditus (Templ.) becomes $\dot{E}$. brasiliensis (Dana), and Siphonoëcetes Whitei (Gosse) E. Colletti, Boeck. 
The following two species are additions to my list, viz., Peltocoxa Marioni, Catta, and Cressa minuta, Boeck, both being recorded from the Forth. This raises the total to 796 .

I need scarcely add that this important work, by one of the foremost of living Carcinologists, is indispensable to those engaged in the study of the Amphipoda.

Before closing I desire to take this opportunity to express my indebtedness to Mr William Evans, F.R.S.E., President of the Royal Physical Society, for the whole-hearted assistance he has given me while this Catalogue was passing through the press. I am also not forgetful of other friends who have shown an interest in my efforts to make this contribution to Scottish Natural History, unpretentious though it be, of some use to students of the Crustacea of Scotland.

\section{Errata in First Part.}

Page 99. Near bottom; for Homarus vulgarus read Homarus vulgaris, and for Crangon vulgarus read Crangon vulyaris.

" 103. Near top; for Paramphithoë monocupis read Paramphithoë monocuspis.

" 107. Near top; for "Stalked-eyed Crustacea" read "Stalk-eyed Crustacea."

, 110. Near bottom; in the reference " 1767 , Cancer rostratus, Linn., Syst. Nat,, ed. xii., vol. ii. p. 1014," for vol. ii. p. 1014 read "vol. i. part ii. p. 1045 "; and in the subsequent references to the twelfth edition of Systema Naturoe, Linné, for "vol. ii." read "vol. i. part ii."

" 113. Near top; for Turretella read Turritella.

" 120. Near top; for Nyctiphanus read Nyctiphanes.

", 122. Near bottom ; in the reference "Reise i Chr. oy," etc., "oy" should be "og."

, 125. In footnote; for "Dr Welley" read "Dr Willey."

", 137. In footnote; for Leptospidia read Leptaspidia.

", 144. Near bottom; Calisoma should be Callisoma in each of the four lines where it occurs.

, 165. Near top; the name Platessoides limandoides is a synonym of Drepanopsetta platessoides. (See also p. 150.)

", 165. Middle; for Cheirocrates read Cheirocratus in four places.

", 189. Near the middle; for "Sonntagshlatt." read "Sonntagsblatt."

Part of the cost of publication of the foregoing Catalogue has been defrayed by a Grant made to the Author by the Carnegie Trust for the Universities of Scotland. 


\section{N D E X}

TO

\section{GENERA AND PRINCIPAL LARGER DIVISIONS.}

(Pages 108 to 190 are in Part I.)

\begin{tabular}{|c|c|c|c|c|c|c|c|c|}
\hline & & & & PAGE & & & & PAGE \\
\hline Acantholeber & & • & . & . 182 & Beatricella, & $\cdot$ & . & - 326 \\
\hline Acartia, . & & & . & . 304 & Bodotria, & . & . & . 126 \\
\hline Acidostoma, & & • & . & . 144 & Bomolochus, & . & . & . 361 \\
\hline Acontiophoru & & • & . & . 358 & Bosmina, & . & ${ }^{\circ}$ & . 180 \\
\hline Acroperus, . & & $\cdot$ & . & . 182 & Brachiella, & . & . & . 373 \\
\hline Aglaia, & & . & . & . 274 & Brachyura, & . & . & . 108 \\
\hline Alona,. & & . & . & . 183 & Bradya, & . & . & . 310 \\
\hline Alonella, & & . & . & . 185 & Bradyidius, . & . & . & - 298 \\
\hline Alonopsis, . & & . & . & . 182 & Bradypontius, & & ${ }^{\circ}$ & . 359 \\
\hline Alteutha, . & & . & . & . 312 & Brancbiura, . & . & . & . 190 \\
\hline Amathilla, . & & . & . & . 162 & Bruzeliella, . & . & . & . 379 \\
\hline Aneira, & & . & . & . 323 & Byblis, & . & . & . 150 \\
\hline Amenophia, . & & - & . & . 316 & Bythocythere, & . & • & . 291 \\
\hline Ampelisca, & & . & . & . 149 & Bythotrephes, & . & . & . 188 \\
\hline Amphiascus, & & 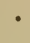 & . & . 321 & & & & \\
\hline Amphilochoid & & 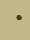 & . & · 151 & Calanus, & - & - & - 297 \\
\hline Amphilochus, & & & - & . 150 & Caligus, & - & - & 366 \\
\hline Amphipoda, & & - & - & · 142 & Calliopius, · & - & - & - 160 \\
\hline Amphithoë, . & & & . & . 169 & Callisoma, . & . & - & - 144 \\
\hline Anapagurus, & & - & . & . 113 & Calocaris, . & . & - & - 115 \\
\hline Anchorella,. & & & . & . 373 & Camptocercus, & . & - & - 182 \\
\hline Anomalocera, & & 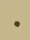 & . & . 303 & Campylaspis, & . & & . 130 \\
\hline Anonyx, & & - & . & . 146 & Cancer, & . & . & . 108 \\
\hline Aora, & & & . & . 166 & Candacia, & . & . & . 303 \\
\hline Apherusa, . & & . & . & . 159 & Candona, . & - & . & . 275 \\
\hline Aplostoma, . & & . & . & . 363 & Candonopsis, & . & . & . 277 \\
\hline Arcturella, & & . & . & . 136 & Canthocamptus, & & & - 328 \\
\hline Argilloecia, . & & . & . & . 279 & Canuella, & - & - & - 306 \\
\hline Argissa, & & . & . & . 158 & Caprella, & . & . & . 174 \\
\hline Argulus, & & . & . & . 190 & Carcinus, & . & . & . 108 \\
\hline Arnadillidiur & & . & . & . 141 & Cecrops, & . & . & 369 \\
\hline Ascidicola, . & & . & . & . 36 & Centropages, & . & . & . 300 \\
\hline Asellus, & & & . & . 136 & Cerapus, & . & . & . 171 \\
\hline Aspidiscus, . & & & . & . 31 & Ceriodaphnia, & . & . & 179 \\
\hline Aspidøecia, & & . & . & . 37 & Charopinus, . & - & & 373 \\
\hline Astacilla, & & . & . & . 135 & Cheirocratus, & . & & . 165 \\
\hline Astacus, & & & 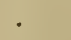 & · 116 & Chondracanthus, & & & . 371 \\
\hline Asterocheres, & & . & . & . 356 & Chydorus, . & & & 187 \\
\hline Asterope, & & & . & . 29 & Cirripedia, . & . & & . 375 \\
\hline Atelecyclus, . & & 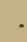 & & . 11 & Cladocera, & & & . 175 \\
\hline Athelges, & & & - & . 14 & Cletodes, . & . & & . 337 \\
\hline Attheyella, & & & · & · 330 & Collocheres, . & . & & - $\quad 357$ \\
\hline & & & . & 279 & $\begin{array}{l}\text { Conchoderma, } \\
\text { Copepoda, }\end{array}$ & : & & $\begin{array}{l}376 \\
296\end{array}$ \\
\hline & & & $\cdot$ & - 37 & Corophium, . & & & 172,379 \\
\hline Bathyporeia, & & 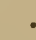 & . & . 147 & Corycæus, . & & & . 360 \\
\hline
\end{tabular}




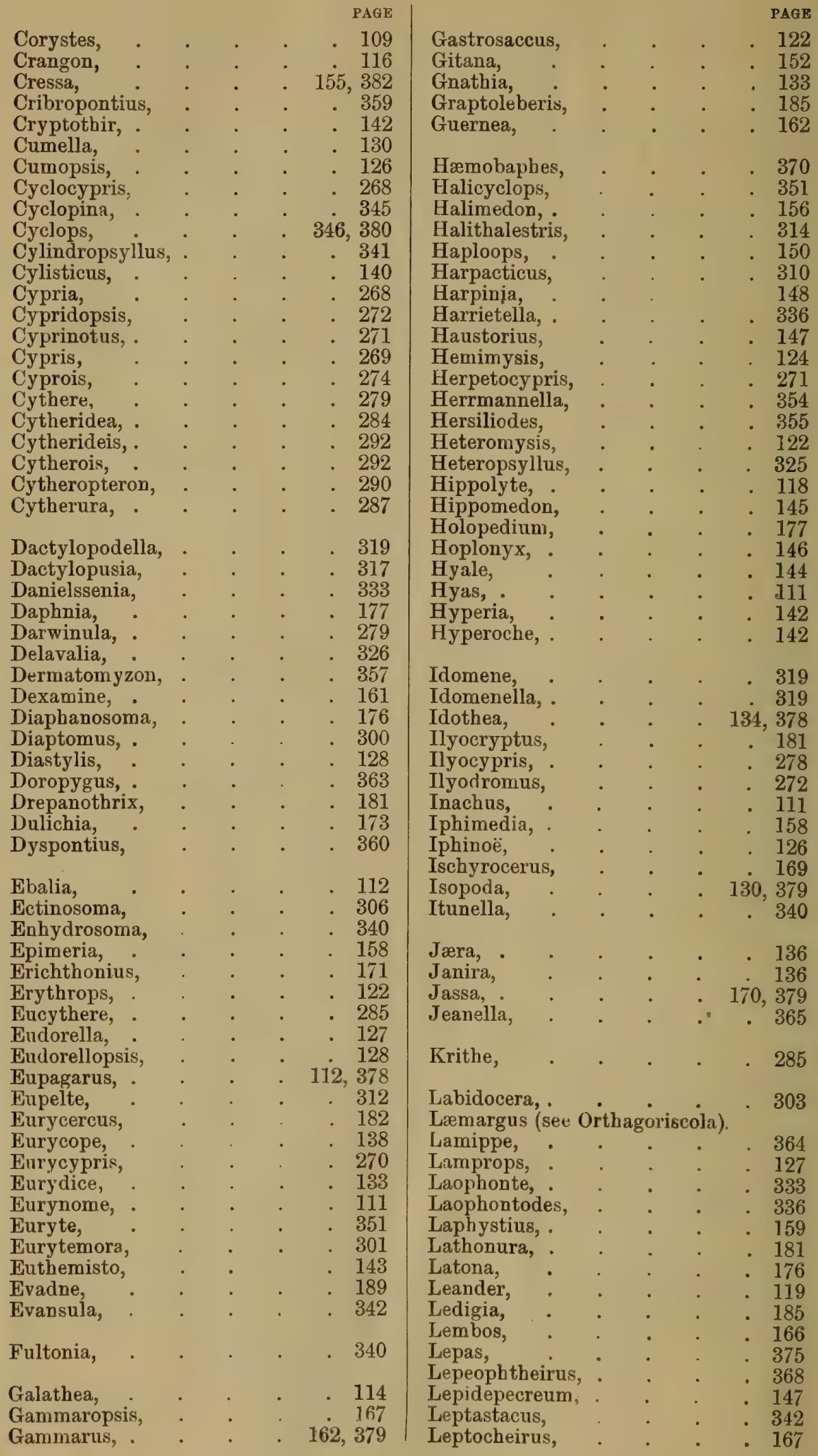


Orchestia, . . . . . 143

Orchomene, . . . 145

Orthagoriscola, . . . . . 369

Ostracoda, . $\quad . \quad$. 267

Pagurus, . . . . . 378

Pandalina, : $\quad: \quad \circ \quad \div 119$

Pandalus, . . . . . . 119

Paracalanus, . . : $\quad 298$

Paracandona, . . . . 277

Paradoxostoma, . . . . 293

Paramesochra, . . . . 344

Paramphithoë, . . . 157

Paramunna, . . . . 137

Parapontella, . . . . 303

Parartotrogus, . . . $\quad 360$

Paratanais, . . . . 131

Parathalestris, : $: \quad . \quad 314$

Machærina, . . . . . 294

Macromysis, : : : : 124

Macropodia, : : : $\quad 110$

Macropsis, . . . . . 124

Macrotbrix, . . . . 181

Macrura, . . . . . 112

Mæra, . . . . . 164

Maraenobiotus, · . . . 332

Megaluropus, : : : : 164

Megamphopus, . . . . 168

Melita, . . . . . 163

Melphidippella, . . . . 162

Mesochra, . . . . . 332

Metopa, : . : . 153

Metopella, · . . . . 154

Metoponorthus, . . . 379

Metridia, . . . . . 302

Microdeutopus, . . . . 166

Microprotopus, . . . . 168

Microsetella, . . . . 309

Microthalestris, . . . . 315

Misophria, . . . . . 305

Modiolicola, . . . . 354

Monoculodes, : : : : 155

Monospilus, . $\quad$. $\quad$. $\quad$. 188

Monstrilla, . . . . . 365

Moraria, : . . : 331

Munida, . . . . . 115

Munna, . . . . . 137

Mysidopsis, : : : : 123

Parathemisto, . . . . 143

Paratylus, . . . : $\quad 160$

Pariambus, . . . . . 174

Peltocoxa, . . : : $\quad 382$

Peltngaster, . . . . . 378

Peratacantha, . . . . $186^{\circ}$

Perioculodes, . . . . 156

Petalosarsia, . . . . 130

Philomedes,. . . . $\quad .295$

Philoscia, . . . . 140

Photis,. . . . . . 168

Phoxocephalus, . : $\quad$ : 148

Phryxus, . . . . . 141

Phtisica, · • . . 174

Phyllopodopsyllus, . . . 343

Phyllothalestris, . . . . 314

Pinnotheres, . . . . 110

Pionocypris, . . . . 272

Platyarthrus, . . . . 140

Platychelipus, : $\quad$ : $\quad$ : 341

Pleonexes, : • . . . 169

Pleurogonium, . . . : 137

Pleuroxus, • . . . . 186

Podoceropsis, . . . . 168

Podon,. . . . . . . 188

Polycope, . . . . . 295

Polycopsis, . . . . . 295

Polyphemus, . $\quad$. $\quad$. 188

Pontocrates, . . . . 156

Pontocypris, . . $\quad . \quad \div 278$

Pontopolites, - : . $\quad$. 328

Porcellana, . . . . 114

Porcellidium, : $\quad: \quad \therefore 312$

Porcellio, . . . . 140

Nannopus, · · · . $\quad 340$

Nematosceli, . . . . 121

Neobradya,". . . . 306

Neomysis, . . . . . 125

Nephrops, . . . . . 116

Nicothoë, · • • • . 361

Nika, . . . . . 117

Nitocra, . . . . . 331

Normanella, $\quad \cdot \quad \cdot \quad \cdot 337$

Notodelphys, · · · . 362

Notodromas, . . . . 274

Nyctiphanes, • • . . 120

Oithona, . . . . . . 345

Oniscus, : $\quad \cdot \quad \cdot \quad \cdot \quad \cdot 139$

Portumnus, . . . . 109

Portunus, . . . . . 108

Potamocypris, . . : $\quad 273$

Protella, . . . . 174, 379

Protomedeia, . . . . 166

Pseudanthessius, . : : $\quad 353$

Pseudobradya, . . . $\quad .309$

Pseudocalanus, : : $: \quad \div 298$

Pseudocaligus, • . . . 367

Pseudocuma, . . . . 129

Pseudocyclopia, . . . . 299

Pseudocyclops, . . . . 302

Pseudocythere, . • . . 292

Pseudoprotella, . . . . 379

Oralien, $\quad$ - $\quad$ : $\quad$. 371

Pseudothalestris, . . . . 316 


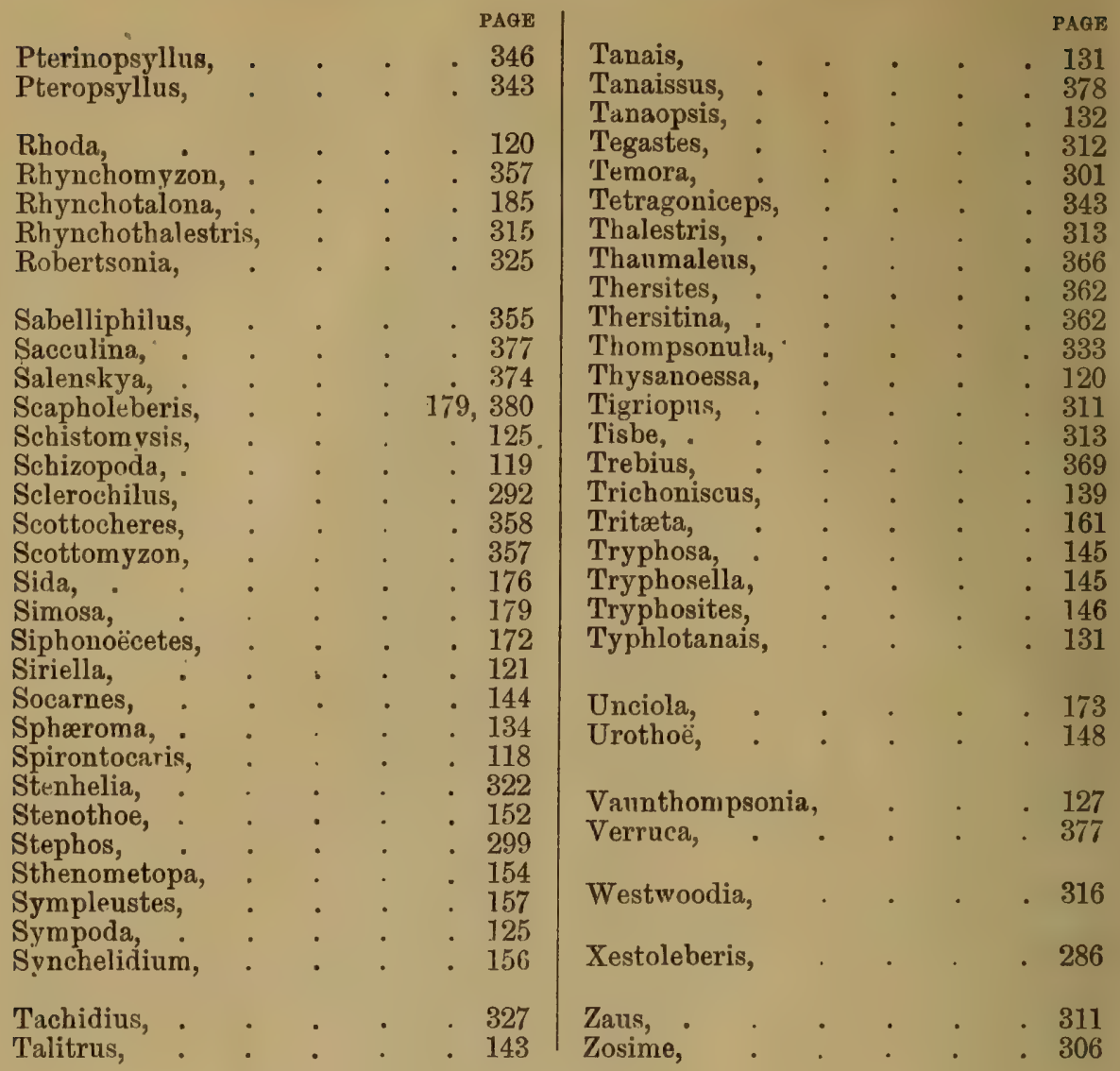

For some recent changes in nomenclature, see p. 381 . 


-

$$
\text { - }
$$





\section{.}




3

$\therefore \div$

$0=32=353$ ?

3

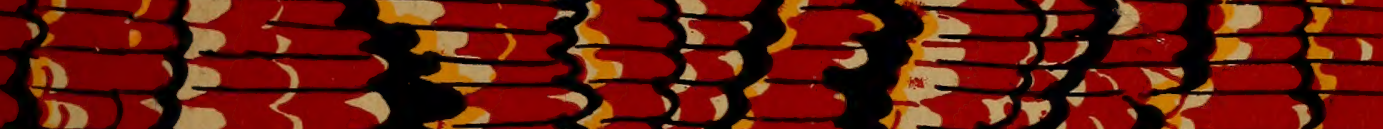

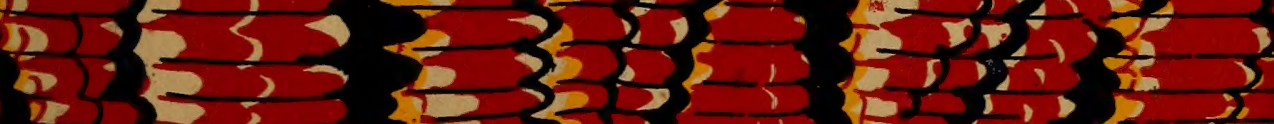

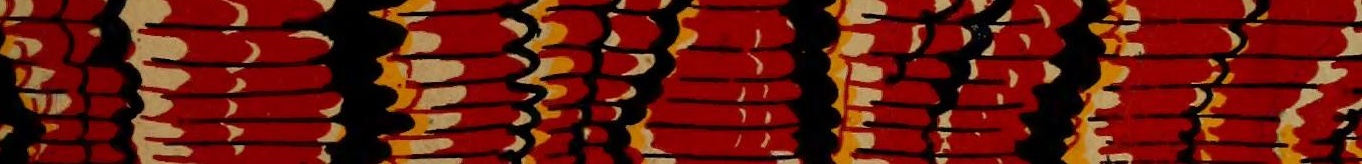

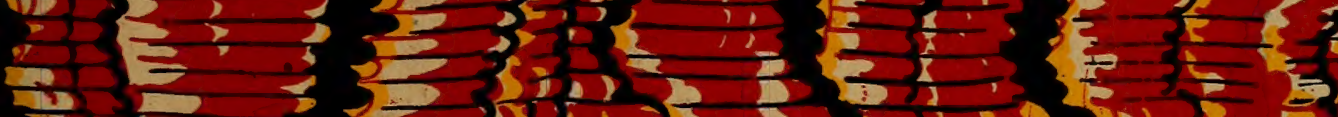

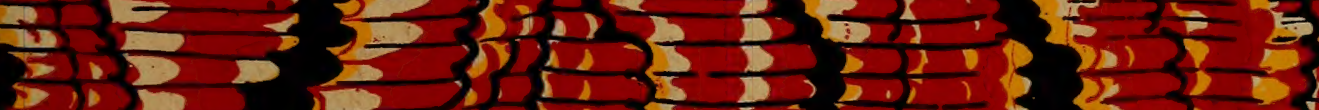

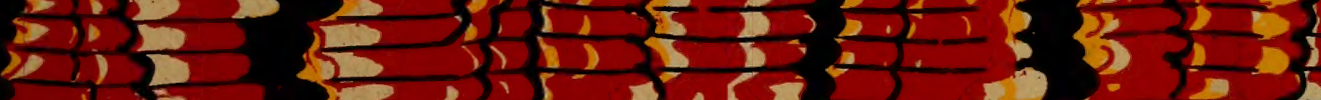

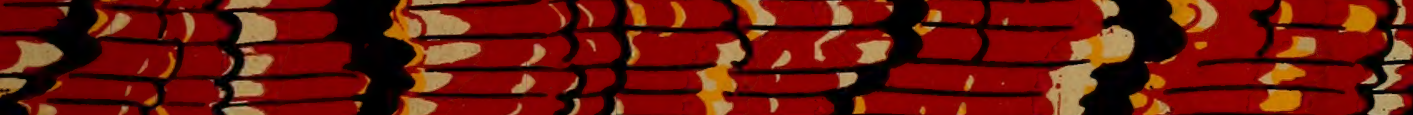

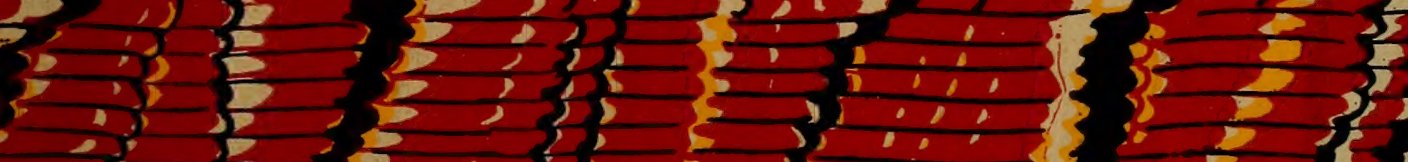

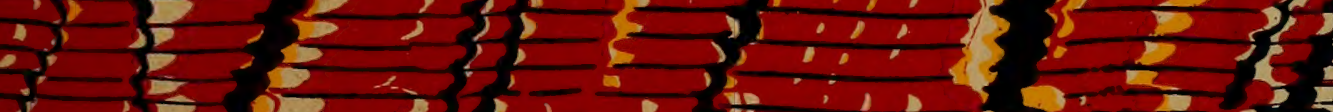

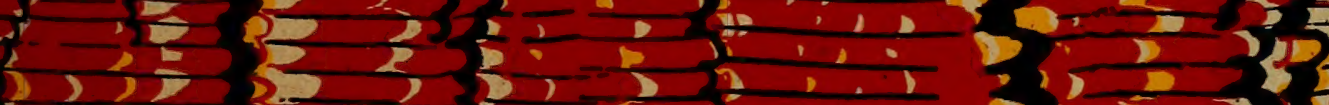

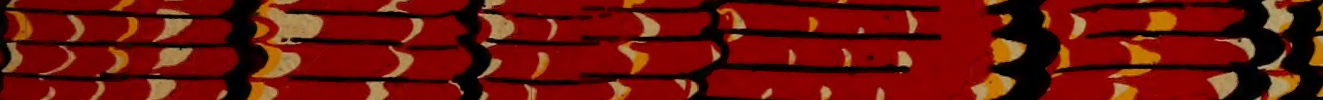

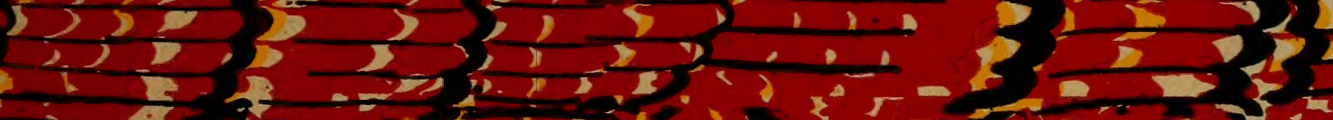

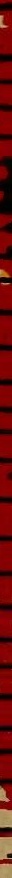

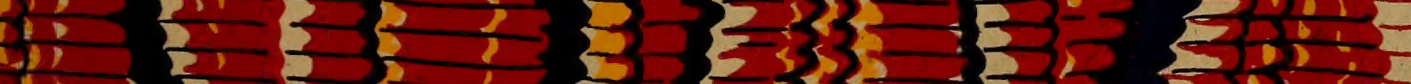


